
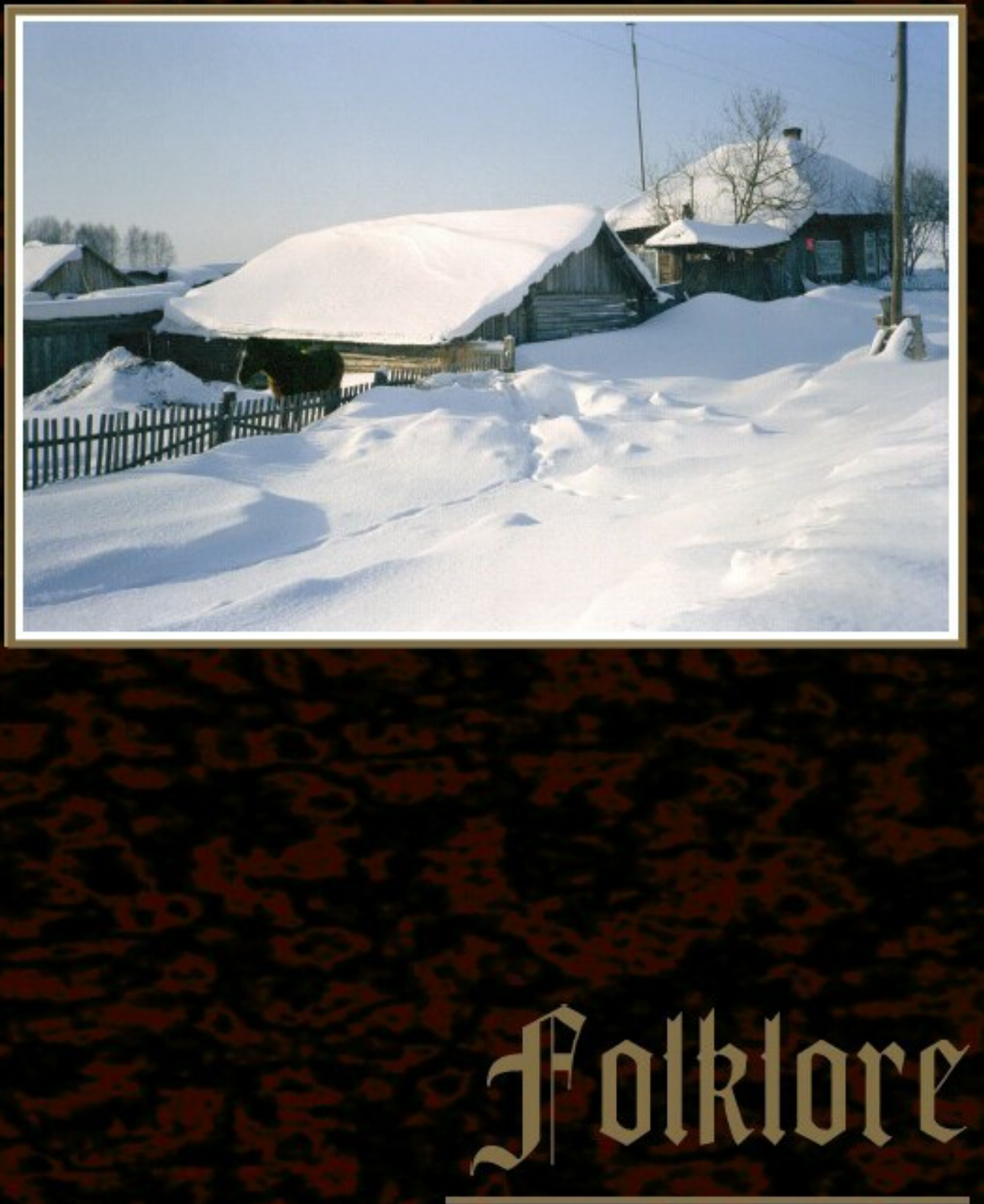

Electronic Journal of Folklore 58 


\section{Folklore}

Electronic Journal of Folklore

http://www.folklore.ee/folklore Printed version

Vol. 58

2014 
Folk Belief and Media Group of the Estonian Literary Museum

Estonian Institute of Folklore

\section{Folklore}

Electronic Journal of Folklore Vol. 58

Edited by Mare Kõiva \& Andres Kuperjanov Guest editor: Anu Korb

Tartu 2014 
Editor in chief

Co-editor

Guest editor

Copy editor

News and reviews

Design

Layout
Mare Kõiva

Andres Kuperjanov

Anu Korb

Tiina Mällo

Piret Voolaid

Andres Kuperjanov

Diana Kahre

Editorial board 2008-2014: Dan Ben-Amos (University of Pennsylvania, USA), Larisa Fialkova (University of Haifa, Israel), Diane Goldstein (Memorial University of Newfoundland, Canada), Terry Gunnell (University of Iceland), Jawaharlal Handoo (University of Mysore, India), Frank Korom (Boston University, USA), Monika Kropej (Institute of Slovenian Ethnology), Kristin Kuutma (University of Tartu, Estonia), Aado Lintrop (Estonian Literary Museum), Wolfgang Mieder (University of Vermont, USA), Irina Sedakova (Russian Academy of Sciences).

The journal is supported by the institutional research funding IUT22-5, the state programme project EKKM14-344, and the Estonian Literary Museum.

This special issue was supported by the institutional research funding IUT22-4 "Folklore in the Process of Cultural Communication: Ideologies and Communities" of the Estonian Ministry of Education and Research, and by the national programme "Estonian Language and Cultural Memory", project "Estonians in Russia: Settlement History and Cultural Heritage".

Indexed in EBSCO Publishing Humanities International Complete, Thomson Reuters Arts \& Humanities Citation Index, MLA International Bibliography, Ulrich's Periodicals Directory, Internationale Volkskundliche Bibliographie / International Folklore Bibliography / Bibliographie Internationale d'Ethnologie), DOAJ, C.E.E.O.L., ERIH (B)

\section{Editorial address:}

Folklore: Electronic Journal of Folklore

Vanemuise 42-235

51003 Tartu

Estonia

phone: $\quad+3727377740$

fax: $\quad+3727377706$

e-mail: folklore@folklore.ee

home page: http://www.folklore.ee/folklore

All rights reserved

(C) Folk Belief and Media Group of the Estonian Literary Museum

EKM Teaduskirjastus / ELM Scholarly Press

Estonian Institute of Folklore

Authors

Design Andres Kuperjanov

ISSN 1406-0957

doi:10.7592/FEJF2014.58 


\section{CONTENTS}

From Collecting to Studying the Folklore of Siberian Estonians

and Latvians: Background

Anu Korb

The Symbols and Stereotypes of Siberia for Estonians and

Their Historical Background

Aivar Jürgenson

Latgalian Emigrants in Siberia: Contradicting Images

Sanita Reinsone

In the Beginning, This Was an Empty Place...

Place-Related Narratives in Timofeyevka, Siberia

Sandis Laime

We Have Nothing to Do with Them; They Live with Their

Own Kind: Siberian Estonians' Representations of the

Neighbouring Turkic Peoples

Astrid Tuisk

The Interrelationship of Religion and Magic in the Experience of Latvians in Timofeyevka, Siberia

Aigars Lielbardis

The Funeral Culture of Estonians in the Minusinsk Region,

Siberia, as a Representation of the Community and

Its Transformation

Anu Korb

Seto Singing Tradition in Siberia: Songs and 'Non-Songs'

Andreas Kalkun, Janika Oras 


\section{Museology}

On Estonian Folk Culture: Pro et contra Piret Õnapuu

NEWS IN BRIEF

Mare Kõiva 60. Piret Voolaid

"Friends, Though Absent, Are Still Present". Wolfgang Mieder

President's Folklore Award and Folklore Collecting in 2013. Astrid Tuisk

Book REviews

Era of Memes in Digital Culture. Mare Kalda

Contemplating Fairy Tales. Kärri Toomeos-Orglaan 


\title{
FROM COLLECTING TO STUDYING THE FOLKLORE OF SIBERIAN ESTONIANS AND LATVIANS: BACKGROUND
}

\author{
Anu Korb
}

In December 2008, the joint conference of Estonian and Latvian researchers of culture, 'Compatriots in Siberia', was held at the Estonian Literary Museum (for the abstracts see The Estonian-Latvian Conference 2008). At the conference, an idea was put forward to compile a collection of articles based on the research of compatriots of these two countries in Siberia, to introduce the corresponding work and studies to a wider audience. The publication is now presented as a special issue of journal Folklore: Electronic Journal of Folklore. The articles published in this volume are authored by folklorists and ethnologists from Estonia and Latvia. Among the conference participants were also linguists and teachers Lidia Leikuma, Alekseis Andronovs, Kristine Zute and Mara Mortuzane, who have carried out a study on the Latgalian language in the Latgale region of Krasnoyarsk Krai; Eta Nikolaeva and Solveta Logina, who have analysed the activities of winter workshops in Achinsk, Krasnoyarsk Krai; and ethnologist Igor Tõnurist, who has studied folk music practices and folk musicians in Siberia. At the conference two documentaries were screened: Liene Linde and Dainis Juraga's No Country for Catholics, and Andres Korjus's On Foreign Lands: Native Estonians in Siberia. In the White Hall of the University of Tartu History Museum, joint exhibition of the Estonian Literary Museum and the Estonian Academy of Arts, titled Siberi eestlased / Estonians in Siberia, was displayed (the curators of the exhibition were Anu Korb and Kadri Viires). 


\section{ON SETTLEMENT HISTORY}

During deportations and forced migration to Siberia (which intensified in the first part of the 19th century) and at the peak of emigration (1890-1918), Estonia and Latvia were part of the Russian Empire. The destinies of the Estonians and Latvians who settled in Siberia are closely interrelated with each other and with other Lutheran peoples in Russia - Germans and Finns. The establishment of colonies consisting of Lutheran peoples mainly served the interests of the clergy, as Lutheran ministers were needed to care for the religious needs of the newly settled peoples. The Lutheran confession of faith, with which they had grown up, had always had an important role in the identity construction of the settlers (Jürgenson 2002: 226-229).

\section{MEDIA COVERAGE AND OVERVIEWS OF COMPATRIOTS}

Discussions about the Estonians' and Latvians' migration and descriptions of their life in Siberia abounded in the newspapers of the second half of the 19th and first half of the 20th centuries (see Jürgenson 2002: 83-100; Reinsone in this volume). Often the first ones to provide such information were Lutheran pastors and vicars/schoolmasters (e.g., Jaan Nebokat, Georg Eduard Luiga). In 1900, Jüri Meomuttel was the first to write an overview on Estonians, entitled Eesti asunikud laialises Vene riigis. Esimene katse sõnumid kõikide Eesti asunduste üle tuua ('Estonian Settlers in the Great Russian Empire: The First Attempt to Spread News about all Estonian Settlements'). By this time, migration to Siberia had not yet reached its peak. In 1918, when the majority of Estonian villages in Russia had already been established, August Nigol, a gymnasium teacher and active supporter of Estonian settlements in Russia, published a more extensive overview, Eesti asundused ja asupaigad Venemaal ('Estonian Villages and Places of Residence in Russia'). The book provides statistical data on the settlements (incl. name, location, population, presence of school and church, etc.) arranged by regions, information about the natural conditions and cultural life of the place.

The first attempt to give an overview of Latvian settlements in the diaspora was made by K. Škilters in Latkoloniju vēsture ('History of Latvian Settlements') 
in 1928, and ten years later, in 1938, by Vilbert Krasnais in the comprehensive Latviešu kolonijas ('Latvian Settlements'), the latter of enlists all the known Latvian settlements in the world by region, with additional information on their schools, churches and social life (see further in Lielbardis in this volume).

\section{RESEARCH ON THE SETTLEMENTS IN THE SOVIET PERIOD AND AFTER THE COLLAPSE OF THE SOVIET UNION}

With the annexation of Estonia and Latvia by the Soviet Union in 1940, the study of compatriots in these countries withered. After the Second World War, the Estonians and Latvians who lived in different parts of Russia, except for border zones which required a special visiting permit (e.g., in the Middle East, at the Pacific Ocean), could be visited, but the authorities did not look favourably upon conducting research on compatriots. After independence was restored in Latvia, Latvian journalist and dissident Ingvars Leitis, historian by education, published material on his attempts to study Latvians in Siberia during the Soviet period. When he and photojournalist Uldis Briedis set a goal to visit all the fifty villages in which Latvians had settled in Siberia, as Škilters claimed in his book Latkoloniu vêsture in 1928, the endeavour was soon declared forbidden (see Lielbardis in this volume). Nor was the study of compatriots favoured in Soviet Estonia: for example, Nigol's book on Estonian villages and settlements in Russia was held in a special archive fund and was accessible only to researchers who had earned the "trust" of the authorities (Korb 2007: 19). Some works, such as the monograph, Uut elu ehitamas: Eesti vähemusrahvus NSV Liidus (1918-1940) ('Rebuilding Life: Estonian Minority in the Soviet Union, 1918-1940'), by historian Viktor Maamägi, were written to the tune of Soviet propaganda, but the worth of his work lies in the extensive use of Russian archive materials.

An important moment for Estonian folklorists was the field expedition led by Igor Tõnurist, an ethnography student at Moscow University at the time, to the Estonians who lived in the Minusinsk region in Siberia in the mid-1960s. Through Tõnurist's mediation and with his help, the Department of Folklore of the Estonian Literary Museum established contacts with Rosalie Ottesson from Verkhnaia (Upper) Bulanka village in Siberia. Ottesson became the department's long-term informant, sending nearly 3,000 pages of folklore material between 1969 and 1976 (Korb 2013: 7-26). The material recorded by a woman 
who had received a Soviet upbringing and was living in a traditional community is of high research interest.

Since the 1980s, after the situation became less oppressive, interest in studying Estonians in Siberia and collecting materials associated with them started to gain impetus. At the time, it remained the initiative of a few enthusiasts. More serious collecting and research in Estonia was done by linguists Jüri Viikberg and Lembit Vaba (see, e.g., Viikberg \& Vaba 1984: 145-156; Viikberg 1988: 284-288), who collected material mainly in the Siberian villages, in which the north-Estonian language variety was spoken. From 1987 onward, ethnologist Mare Piho (see, e.g., 2002: 171-185) and others took up studying the Seto communities in Siberia. During the years under the Soviet rule, opportunities to carry out fieldwork largely depended on the management of a given research institution, as alternatives to apply for research funding were not available.

With the alleviating pressure of Soviet ideology and the growing interest in one's ethnic roots and history, diaspora research gradually gained popularity both in Estonia and Latvia. Initially, interest was shown in the compatriots who lived in the Western countries (e.g., the United States, Canada, Sweden), because during the Soviet regime normal contacts with them had been impossible to maintain. Interest in our compatriots in Siberia began to grow as late as in the early 21 st century.

Also, some Russian researchers have taken interest in the ethnic processes in Siberia. Ilia Lotkin, ethnographer from Omsk, published two monographs (1996; 2006) on the basis of Estonian and Latvian settlements in Siberia. Lotkin's works rely heavily on the material held in Russian archives, but lack insight into Estonian history, language and culture; also, his work bears clear traces of the impact of Soviet ideology. This seems to be a pervading problem of all researchers in Russia, who have grown up and been educated under considerable ideological pressure (see Jürgenson 2002: 19).

\section{ESTONIAN FOLKLORISTS' FIELDWORK IN SIBERIA IN 1991-2013}

More or less simultaneously with the restoration of the independent Republic of Estonia, the Estonian Folklore Archives started organising field expeditions under the leadership of Anu Korb to the Estonian settlements in Siberia. First we received financial support from the Estonian National Culture Foundation and the Cultural Endowment of Estonia, later on from the Compatriots 
Programme and the national programme "Estonian Language and Cultural Memory". As there was no comprehensive overview available about the current situation of Estonian communities in Siberia, we aspired to carry out a statistical and cultural descriptive mapping and collecting of folklore material as versatile as possible. Before that, Estonian researchers had never worked in one-third of the existing Estonian settlements.

The geography of destinations has been as follows: Verkhnii (Upper) Suetuk and Verkhnaia (Upper) Bulanka (Krasnoyarsk Krai) in 1991 and 1992; Berezovka and Liliengof (Tomsk Oblast) in 1993; Yurievka, Koidula (Kemerovo Oblast), and Vambola (Tomsk Oblast) in 1994; Zolotaia Niva, Semionovka, Ivanovka, and Kovalevo (Omsk Oblast) in 1995; Mikhailovka, Yurievka, Lileika, and Estonka (Omsk Oblast) in 1996; Tsvetnopolye, Staryi (Old) Revel, Novyi (New) Revel, Orlovka, and Kovalevo (Omsk Oblast) in 1997; Estonka, Borovushka, and Oravka (Novosibirsk Oblast) in 1998; Nikolaevka, Rosental, and Uskiul (Novosibirsk Oblast), Ryzhkovo (Omsk Oblast) in 1999; Ryzhkovo and Zolotaia Niva (Omsk Oblast), Verkhnii Suetuk and Verkhnaia Bulanka (Krasnoyarsk Krai), Estonia (Altai Krai) in 2000; Berezovka (Tomsk Oblast) in 2004; Khaidak, Bulatnovka, and Krestiansk (Krasnoyarsk Krai) in 2007, Khaidak, Bulatnovka, and Novo(New)-Pechora (Krasnoyarsk Krai) in 2008; Khaidak, Bulatnovka, Krestiansk, Verkhnii Suetuk, and Verkhnaia Bulanka (Krasnoyarsk Krai) in 2012; Verkhnii Suetuk and Verkhnaia Bulanka (Krasnoyarsk Krai) in 2013.

The aim has been to document folklore in its current state and observe the changes that have occurred in the tradition of Siberian Estonians under the influence of multicultural environment throughout times. The publications compiled on the basis of the material collected in the villages have helped to support the identity of Estonian communities in Siberia.

\section{COMPLEX EXPEDITIONS OF LATVIAN CULTURE RESEARCHERS IN SIBERIA IN 1991 AND 2004-2008}

Siberia has become a fieldwork platform also for Latvian folklorists, ethnomusicologists, linguists and historians that represent such institutions as the Archives of Latvian Folklore, the Faculty of Philology of the University of Latvia, Latvian Academy of Music, and the Museum of the Occupation of Latvia, to name but a few.

Until today, the Archives of Latvian Folklore in cooperation with different organisations have undertaken six expeditions to Latvian villages in Siberia. 
The geography of destinations has been as follows: Nizhnaia (Lower) Bulanka (Krasnoyarsk Krai) in 1991; Timofeyevka (Novosibirsk Oblast) in 2004; Malinovka and Borzunovka (Tomsk Oblast), Sukhonoia, Imbezh, Ostrovki, Kirza, Kamenno Gornovka, Krayevaya, Schastlivoye, Bogatoye, and Bychki (Krasnoyarsk Krai) in 2005; Timofeyevka, Shargari and Shchipchino (Novosibirsk Oblast), Bobrovka, Kurliano Dubovka (Omsk Oblast) in 2006; Bobrovka and Kurliano Dubovka (Omsk Oblast) in 2007; Ryzhkovo (Omsk Oblast) in 2008. In addition to the materials of these fieldworks, the Archives of Latvian Folklore also store some tapes recorded by Ingvars Leitis and Uldis Briedis in Ryzhkovo in 1975 and in Nizhnaia Bulanka in 1976.

There are two facets to Latvian folklorists' fieldwork in Siberia. First, the aim has been to document folklore in its current state, to explore the folklore layers that have been inherited from previous generations, the transformation of this material as a result of intercultural contacts, the absence of different kinds of contexts that have been lost after leaving Latvia, the adaptation of new kinds of traditions, etc. Second, folklore has been explored as an instrument of preserving Latvian identity and demonstrating it on stage at different festivities and festivals of national minorities in Siberia (Laime 2008: 8).

\section{ARTICLES ON COMPATRIOTS IN SIBERIA}

The authors of this special issue of Folklore: Electronic Journal of Folklore all share a common fieldwork experience among their compatriots in Siberia.

Aivar Jürgenson's first contact with Estonians in Siberia was in 1996 as a member of the fieldwork team of the Estonian Folklore Archives; later on he started to organise his own fieldwork expeditions to Estonian communities in Siberia. He defended his doctoral thesis under the heading The Identity and Territoriality of Siberian Estonians at the then Tallinn Pedagogical University in 2002. In his article in this issue, Jürgenson analyses the Siberian stereotypes of Estonians.

Sanita Reinsone participated in the 2004 expedition of Latvian researchers to Timofejevka village, Novosibirsk Oblast, Siberia. In her article, Reinsone offers an insight into migration and diaspora studies on the example of migration texts of the late 19th and early 20th centuries, and also analyses the stories of the descendants of emigrants in the 2000s.

Astrid Tuisk has visited various Estonian communities in Siberia since 1991. Her main field of interest is the local lore of Estonians in Siberia and their 
relations with the neighbouring peoples. Tuisk's article explores how Estonians in Siberia perceive their neighbouring Turkic peoples.

Sandis Laime has conducted fieldwork among various Latvian communities in Siberia since 2004. He has studied local narrative history, which can be traced from the modern perspective to the more distant past. The article is based on materials gathered during fieldwork in Siberia, and focuses on the local narrative history in one Siberian village - Timofeyevka.

Aigars Lielbardis has been a member of several expeditions to Latvians in Siberia since 2004, and has authored documentaries (e.g., Vera and Janis Lacis) based on the material recorded during the fieldwork. In his article, Lielbardis discusses the relationship of religion and magic on the example of the material collected in Timofeyevka village in Siberia.

Anu Korb has organised and supervised fieldwork among Estonians in Siberia, visiting various local Estonian communities between 1991 and 2013. She defended her PhD thesis entitled Estonian Communities in Siberia as a Source for Folkloristic Research at the University of Tartu in 2007. Her article in this special issue discusses the transformation of Siberian Estonians' death culture over time, on the example of Estonians living in a specific region in Siberia.

Andreas Kalkun's first contact with the Setos in Siberia was during the 2007 fieldwork of the Estonian Folklore Archives. In his article, written in cooperation with ethnomusicologist Janika Oras, Andreas Kalkun explores the singing tradition of the Setos in Siberia.

\section{ACKNOWLEDGEMENTS}

This work was supported by the institutional research funding IUT22-4 "Folklore in the Process of Cultural Communication: Ideologies and Communities" of the Estonian Ministry of Education and Research.

\section{REFERENCES}

Jürgenson, Aivar 2002. Siberi eestlaste territoriaalsus ja identiteet. [The Identity and Territoriality of Siberian Estonians.] Tallinn Pedagogical University: Dissertations on Humanities 7. Tallinn: TPÜ Kirjastus.

Korb, Anu 2007. Siberi Eesti kogukonnad folkloristliku uurimisallikana. [Estonian Communities in Siberia as a Source for Folkloristic Research.] Dissertationes 
Folkloristicae Universitatis Tartuensis 8. Tartu: Tartu Ülikooli Kirjastus. Available at http://dspace.utlib.ee/dspace/bitstream/handle/10062/3421/korb_anu. pdf?sequence=1, last accessed on June 27, 2014.

Korb, Anu 2013. Rahvaluule osakonna Siberi kaastöölise Rosalie Ottessoni ja teaduritearhivaaride dialoog aastatel 1969-1976. [Researchers-Archivists and Siberian Correspondent Rosalie Ottesson: A Dialogue from the Years 1969-1976.] Mäetagused, Vol. 54, pp. 7-26. doi: 10.7592/MT2013.54.korb.

Laime, Sandis 2008. Expeditions of the Archives of Latvian Folklore to Siberia. The Estonian-Latvian Conference "Compatriots in Siberia". Mezhdunarodnaia konferentsiia "Estontsy i latyshi v Sibiri". Abstracts. Compiled by A. Korb. Tartu: Eesti Kirjandusmuuseum, p. 8.

Lotkin 1996 = Lotkin, Il'ia. Sovremennye etnicheskie protsessy u latyshei $i$ estontsev Zapadnoi Sibiri. [Modern Ethnic Processes among Latvians and Estonians in Western Siberia.] Moskva: Institut etnologii i antropologii im. N.N. MiklukhoMaklaia.

Lotkin 2006 = Lotkin, Il'ia. Pribaltiiskie diaspory v Sibiri (1920-1930-e gody): Aspekty etnosotsial'noi istorii. [Baltic Diasporas in Siberia in the 1920s-1930s: Aspects of Ethno-Social History.] Omsk: Izdatel'skii dom Nauka.

Piho, Mare 2002. Setude ümberasumisest külmale maale. [The Migration of the Setu People into the Land of Cold.] In: J. Viikberg (comp. \& ed.) Krimmi kogumik. Konverentsi "140 aastat eestlust Krimmis" ettekanded (09.-10. 09. 2001). [The Crimean Papers.] Tallinn: Eesti Keele Sihtasutus, pp. 171-185.

The Estonian-Latvian Conference 2008 = The Estonian-Latvian Conference "Compatriots in Siberia". Mezhdunarodnaia konferentsiia "Estontsy i latyshi v Sibiri". Abstracts. Tartu: Eesti Kirjandusmuuseum.

Viikberg, Jüri 1988. Vanematest Eesti asundustest Siberis. [The Early Estonian Settlements in Siberia.] Keel ja Kirjandus, Vol. 5, pp. 284-288.

Viikberg, Jüri \& Vaba, Lembit 1984. Siberi põhjaeestlasi kõnetamas. [Addressing Northern Estonians in Siberia.] Keel ja Kirjandus, Vol. 3, pp. 145-156. 


\title{
THE SYMBOLS AND STEREOTYPES OF SIBERIA FOR ESTONIANS AND THEIR HISTORICAL BACKGROUND
}

\author{
Aivar Jürgenson
}

\begin{abstract}
Siberia has traditionally been associated with cold, darkness, prisons, and wild nature. Siberia has a negative connotation for Estonians, Latvians and Lithuanians, especially because of Soviet deportations carried out in the 1940s. However, by that time Siberia had already been used as a prison for several centuries. It is mainly for these reasons that the image of Siberia has been negative. Yet, it can also be positive; for example, for those who were born and bred in Siberia and for whom Siberia is homeland. This article analyses the symbols and stereotypes of Siberia for Estonians and their historical background.
\end{abstract}

Keywords: diaspora, image, Siberia, stereotypes, symbols, voluntary and forced migration

A young Estonian man, who had fled from Estonia during the Second World War and had settled in Canada, described his first years in his new abode:

For a longer period already, having lived in this capital of Estonians, together with my family under my own roof, working only five days a week and bringing home a satisfactorily bulky envelope with salary, everything feels so contrastively different to what it was like then, two to three years ago. It is amazing to think that I was here in the very same Canada, which felt like Siberia rather than Mecca for refugees and other immigrants. (Parts 1954: 9)

We do not know what that young man had in mind when he compared Canada with Siberia. Was it the fact that both have a continental climate, cold and snowy winters? One could speculate so, but probably there are also other grounds for comparison. Siberia here is projected as a metaphoric contrast to Mecca - a place that for a Muslim represents the main destination of their earthly wanderings, the destination of their pilgrimage. In the present context, Siberia should symbolise a place that one should rather avoid.

The collection of articles published in Irkutsk in 1987 contains writings by Western journalists and essayists and as such sheds light on the West- 
European and American contemporary imagination of Siberia. A stereotypical picture prevails: a vast land where distance separates people and where isolation has affected people's mental state (Smitt 1987: 104), a wild country with impenetrable forests and blizzardy tundra inhabited in most part by wolf packs (Mowat 1987: 65), Siberia as a destination for deportations (Griffin 1987: 93).

Siberia - for the people in the Baltic countries it is first and foremost a land of barbed wire, and for us the deportations of the 1940s have branded a burning image on the part of the world where Siberia is situated. And nothing shows from underneath that image, even if there was something there previously. Deportations, cattle wagons, anonymous graves - the memoires from Siberia that have been published in abundance, eagerly bring up such images, also occasionally amplified and using the black-and-white contrast. However, this is understandable: we are dealing with a symbol that is confirmed in people's memories and thus continues to strengthen further on. In the above case, the symbol of Siberia is negative.

But this symbol could also be positive; for example, for those who were born and bred in Siberia and for whom Siberia is a homeland, that is, for Siberians.

A symbol is a product of historical experience. Juri Lotman (1999: 223) has labelled symbols as mechanisms of memory, as ties between different cultural cross sections. Especially the temporal dimension enables us to understand quite a few symbols connected to Siberia. In what follows, I will examine different aspects of the image of Siberia and attempt to show how these have emerged and what kind of meaning they convey.

An image is often shaped by stereotypes and prejudices, both of which tend to be enduring. A prejudice is a general attitude about people, groups, or phenomena, and does not succumb to change easily, even if faced with new and contradicting experience. It is a moral judgment with an emotional tinge. The information that supports the prejudice is often incomplete, tilted or erroneous. So, too, is a stereotype, an emotional positive or negative image of a person or a group, an event or a phenomenon. It is fixed and persistent in time as well as resistant to change resulting from new information. The function of a prejudice is to mediate norms and value judgments (which are often seen as universally accepted), whereas stereotypes are used to help a person to navigate in his or her surroundings and communicate with it ${ }^{1}$ (Matthes 1981: 23).

Stereotypes have an important generalisation function and meaning in human communication. Stereotypical concepts about others are a part of collective knowledge; they are acquired in the socialisation process, are regularly confirmed by their constant use in everyday and media discourses, and are used as arguments. Stereotypes reinforce some characteristics of reality whereas others are diminished (Cyrus 2001: 165; Burke 2001: 125). 
Since symbols are connected to stereotypes, we also have to analyse the stereotypes of Siberia when talking about its symbols.

In the following I will show in which way the symbols and stereotypes of Siberia are products of a historical process and as such have various starting points and sources. What happens when different stereotypes with different origins start to shape the image of Siberia? This paper aims to bring out the heterogeneity and controversy of the image of Siberia. I mainly concentrate on the symbols and stereotypes of Siberia in Estonia, but as these symbols and stereotypes have partly been borrowed from elsewhere, I also briefly describe the international background of those stereotypes. Since the main source for the stereotypes of Siberia for Estonians is direct contacts with Siberia, I will mainly concentrate on this. The deportations of the Estonian offenders to Siberia in the 19 th century, the voluntary agrarian migration in the 19th and the beginning of the 20th centuries, and the mass deportations of the Stalin era in the middle of the 20th century have influenced the formation of Estonians' stereotypes of Siberia in different ways. As sources, I have used Estonian printed media from the second half of the 19th and the 20th centuries, first and foremost printed press. From the earlier period, I have also used the Baltic-German travel literature, in which the main symbols and stereotypes of Siberia are reproduced. As a comparison, I also use the interviews conducted with the Siberian-born Estonians, which I collected during several expeditions to Siberia in the past 15 years.

\section{SIBERIA AS A LAND OF DEPORTATIONS}

For Estonians, the image of Siberia has largely been influenced by both historical events and writings about them. First I will look into how Siberia was portrayed in the 19th and beginning of the 20th centuries. Gustav Blumberg, the author of the first Estonian country studies textbook, writes at the end of the third quarter of the 19th century: “...every child knows that criminals are sent to Siberia” (Blumberg 1874: 89). The quote convincingly demonstrates that Siberia's negative image as a destination for deportations must have been general knowledge. And so it was. In fact, this was the case even considerably earlier.

At the beginning of the elaborate travelogue that Joachim Christoph Friedrich Schultz published anonymously under the name of "a Livonian", there is a list of places that the reader should not visit. Schultz writes that in France there is the threat of the guillotine, in Spain the peril of bandits, and about Siberia he writes that only people who are forced to go there, really do (Schultz 
1795/96: II-III). Where does the image of Siberia as a prison of forced labour originate from?

At first, Siberia was not the only destination of deportations in Russia: people were sent to several other less populated regions of the country. However, at the end of the 17th century, Siberia became the main destination. A Russian regulation from 1753 allowed substituting capital punishment with deportation. After that, the number of people deported to Siberia amounted to 10,000 a year at times (Spiridonova 1999: 7; Kaczýnska 1994: 13; Thomas 1982: 25-27; Lincoln 1996: 213). In the 19th century the population of Siberia grew considerably due to deportations. During the reign of Alexander I, 2000-3000 deported civilians arrived in Siberia a year, but in the middle of the 19th century the number was already up to 19,000 (Lincoln 1996: 192; Watrous 1993: 115; Wood 1991a: 10-11).

From the statistics on deportations in the 19th century, drawn up by A. D. Margolis, we learn that during $1807-1881$, 635,319 people were sent to Siberia, and this tendency was steadily increasing: in the years $1812-1821$ it was 39,761 people, in 1822-1831 - 91,709 people, in 1832-1841 - 78,823 people, in 1842-1851 62,495 people, in $1852-1861$ - 70,570 people, in 1862-1871 - 123,543 people, in $1872-1881-173,039$ people; in $1882-1898-148,032$ people. The majority of the deportees were men and although many arrived together with families, most of them came on their own (Margolis 1975: 224). The Tsarist Empire used deportation to Siberia not only to send criminals out of the central regions of Russia, but also as a means to colonise the sparsely inhabited areas of Siberia.

The importance of deportations in colonising Siberia was already emphasised by the 19th century authors, starting with the leader of Siberian regionalists N. Yadrintsev (1882). Also, the Soviet authors were generally of the opinion that deportations played a significant role in developing the Russian population in Siberia (see Kolesnikov 1975: 38).

The fact that Siberia was used as a destination for deportation created a negative image of the region in the eyes of European Russia and the rest of the world.

When Alexandr Salomon, the director of the Main Prison Administration of Russia in the years 1896-1900 called Siberia "a vast roofless prison", he used an old stereotype. When American journalist George Kennan and artist George A. Frost came to Russia in 1884 as recruitees of the New York "Century Magazine", they could not imagine the difficulties ahead of them. "One does not travel to Siberia for fun," a police officer in Perm who had studied their backgrounds told them. Soon after Kennan had come into contact with prisoners sent there and other deportees in Siberia, he understood these words perfectly well. Kennan's travel book that he published as a sequence in the "Century 
Magazine" - and later also as a book - and in which he paid attention to the situation in the Siberian prisons (Kennan n.d.), shocked the world and deepened the negative image of Siberian prisons in many countries even further.

Estonians were also sent to Siberia. It is likely that the first Estonians reached there already during the 17th century as prisoners of war (Jürgenson 2006: 28); however, this can be thought of as an isolated case that did not receive wider attention in Estonia. The 19th century deportations are a different story altogether. Relying on court documents, historian Aadu Must has pointed out a large number of cases when Estonian peasants were sent to Siberia as punishment for crimes they had committed (Must 2012: 188ff.).

Several Estonian villages in Siberia have come to existence as settlements of the deportees: Verkhnii (Upper) Suetuk in 1850, and Verkhnaia (Upper) Bulanka and Revel (Viru village) in 1861. Both in the 19th century and at the beginning of the 20th century, pastors and schoolteachers from these villages sent tens of overviews to Estonian newspapers, deepening the image of Siberia as a destination for deportations.

At the end of the 19th and beginning of the 20th centuries many writings were published in Estonia, which depicted deportation to Siberia as an act of state-inflicted violence and the deportees as victims. For instance, in the novels and short stories of several Estonian leftist writers the protagonists' crimes and subsequent deportation to Siberia were explained by social injustice and the deportees were depicted with sympathy (Mihkelson 1906; Vilde 1896, 1924). However, it is important to add that among the people sent to Siberia there were also real criminals and recidivists.

We can talk about Siberia as an important factor in the state governmental system, i.e., it was the government with its sanction mechanisms that formed a negative image of Siberia. But one has to take into account the fact that when Russia sent its criminals to Siberia, this spared the European part of Russia and its inhabitants, but created problems in Siberia.

A serious problem was vagabondage: across the whole Siberia no more than $45 \%$ of the deportees stayed in the villages that they were assigned to. At the end of the 19th century, the percentage of the escaped people who had been deported to Siberia, according to different authors, amounted to 30,000-40,000 (Wood 1991c: 123-124; Kaczýnska 1994: 123-125); these were people who, with their criminal activity, spread fear among local villagers and contributed to the fact that its negative image deepened also outside Siberia. 


\section{THE DEPICTIONS OF SIBERIA AS A LAND OF DEPORTATIONS IN THE 19TH- AND 20TH-CENTURY ESTONIAN WRITTEN WORD}

In the second half of the 19th and beginning of the 20th centuries, several writings were published in the Estonian press about the stereotype of Siberians and Siberian Estonians as criminals. It does not always become evident from the texts whether the authors of these writings have in mind a Siberian in general, i.e., a Russian-speaking Siberian, or they mean the Estonians in Siberia. With some texts, however, it is clear that an inhabitant of Siberia in general has been meant.

"The inhabitants of the Siberian taiga have run together from all four winds and they are willing to break each other to get ahead in life," said an article in the newspaper Postimees in 1900 (Postimees 1900: 1-2). R. Lipp, who served in Altai as assistant forester, writes about the Siberian peasants with dull spirit and phlegmatic temper, who can only be weaned from crime by catching them in the act and informing them in a physical manner about how it is forbidden to covet the property of others (Lipp 1939: 6). At times Siberians are depicted as people with degenerate morals, all of which is related back to the image of Siberia as a destination for deportations: the biggest criminals were sent to Siberia (Olevik 1894: 829). A letter sent from Siberia reads: "If there is but a spark of reason from the homeland left in a person's heart, then it must, in one way or another, wither in the prisons" (Sakala 1894b: 3). In another letter there is a story of how a local brewer had cheated a person [probably an emigrant] in financial matters. The settler who penned the letter adds: "No wonder, in Siberia everybody is like that, graduates of the university of evil and thus plenty smart for cheating" (Walgus 1885: 2).

In the literature from the end of the 19th and beginning of the 20th centuries, similar stereotypical images were also ascribed to the Estonians who inhabited Siberia. Georg Eduard Luiga, who at the end of the 19th century worked as a schoolteacher in a village of Estonian deportees for a few years, named his collection of short stories about Siberia in a very telling way - Wägiawallamaal (In the Land of Violence) (Luiga 1912) - and here violence meant not only the state's violence against the people deported to Siberia. This title is also an expression of the author's proposition that these deportees continued to be violent themselves.

Deportations have also added some colour to the image of Siberia. Therefore, it may sound as a surprise that in reality the percentage of the deportees in the population of Siberia has never been very high. In 1662, that is, 80 years after the beginning of the conquest of Siberia, there were 70,000 males registered in Siberia, out of whom 7400 , or $10.5 \%$, were deportees. In the middle of the 19th 
century, the deportees formed 10-11\% of the population of Siberia (Wein 1999: 55). Later on, this percentage started to fall, so that by 1897 the percentage of the deportees in Siberian population was $5.2 \%$ or $5,760,000$ people (Wood 1991b: 118). But by that time the stereotype of Siberia as a land of criminals had established itself strongly in the rest of the world.

After the First World War, Estonia became an independent country and deportation to Siberia was no longer a threat, but still the region's image endured in popular memory and writings. In 1932 the newspaper Postimees published a piece about the difficult life of ditch diggers and titled it metaphorically: The 'Siberia' of Volunteers: About the Loggers and Ditch Diggers of Alutaguse (Postimees 1932: 4).

Also during the Soviet period the use of Siberia as a prison was continued. From the 1930s until his death in 1953, Stalin sent political prisoners to the Siberian mines, where they usually stayed until their death. And probably the finishing touch to the negative image of Siberia was given by the mass deportations that started with the Chinese and Koreans from around Vladivostok during the second half of the 1930s, deportations to Siberia of Volga Germans and several Caucasus peoples in the 1940s, and mass deportations from the Baltic states in the same decade (see Jürgenson 2008: 191ff.).

The most extensive deportations in Estonia took place in 1941 and 1949. As memory researchers have pointed out, in Estonians' collective memory the different mass deportations have fused into a single big martyrdom. The meaning of the event is accepted while the details are not brought to the fore, but remain in the background (Kõresaar 2005: 104).

Previously mainly in Estonian exile communities in Western countries (Kaup 1963; Kopperman 1972; Rävälä 1981) but recently also on this side of the Baltics (Kiik 1988; Viitar 1990; Veisserik 1995; Silliksaar 2001; Hinrikus 1999; Õiger 2011) there have been numerous publications of memoirs and fictionalised writings of the deportees, which strengthen the connection of Siberia to injustice, terror and violence.

Aili Viitar, a former deportee, describes the reactions of the ones deported from Estonia:

Without any court, without giving legal proof of guilt, one is arrested from one's sleep and deported. Where? Even that we were not told. To Siberia, this was what we ourselves worked out. Where else? Since primeval times, Russia has deported its convicts to the cold country. Truly, they would not want to take us to the Crimea for a holiday! (Viitar 1990: 13) 
These examples should prove that one of the most important aspects of the image of Siberia is its long-term use as a destination for deportations. Siberia has become a frightening place where one will not go voluntarily.

Several years ago a children's summer camp programme was started between the Siberian Estonian community and home Estonia. Initially it was intended as an exchange programme, but in reality it has meant that only Siberian Estonian children come to Estonia for a summer camp: in Estonia it is difficult to find parents who would voluntarily like to send their children to Siberia.

The "demonisation" of Siberia is also expressed by deliberately absurd newspaper titles: "Voluntarily to Siberia" (Ranne 2000); "Voluntarily in Siberia" (Saarmaa 2000). During the Soviet period, north-east Estonia was referred to as Estonian Siberia because initially prisoners of war laboured there to rebuild areas destroyed by the war (Pae 2012: 36). This nickname also gives evidence of Siberia's rooted outstandingly negative image due to using Siberia as a destination for deportations.

\section{THE NATURE OF SIBERIA AND ITS DEPICTIONS}

Two years ago, when a cold front moved across Central Europe, there was the following headline in an Austrian newspaper, reading: "Wetter: Sibirien lässt grüßen” (Weather: Siberia Sends Its Greetings) (Kurier 2012). Thus, Siberia reached Europe, let the thermometers drop extraordinarily low, stalled car engines and covered lakes and rivers with ice. Siberia has become a symbol for a cold place - and that already long before one started to record cold records in the world. Of course, in terms of this, Siberia undoubtedly takes the first prize: the lowest temperatures in Siberia have been measured in Oimyakon, the world's pole of cold (outside of Antarctic), where the thermometer has indicated -71 degrees Celsius (French 1989: 1; Mote 1998: 3).

Freezing cold, but also wilderness and impenetrable forests have been part of Siberian image throughout centuries. These characteristics have emerged due to travellers and travel literature. Already the travellers from Western Europe, who, from the 18 th century onwards, increasingly travelled to Siberia and recorded their observations, emphasised the cold climate of Siberia. J. Dundas Cochrane (1825: 5) describes how axes break and how iron sticks if you touch it with a bare hand in the Siberian frost. O. Finsch writes with despair about the clothes that he had taken along from home. These clothes could be appropriate in German cold weather but not in Siberia. Despite his woolly clothes, a double waistcoat, hunter coat and furs, he was freezing in the Siberian frost, despite the fact that it was already April and spring had set in (Finsch 1879: 32-33). 
In Estonia Siberia also symbolised cold. The newspaper Perno Postimees wrote in the freezing winter of 1864: "The cold grows stronger every day; it is almost proper Siberian cold" (Perno Postimees 1864: 37). The Estonian reader got an idea of Siberian cold winters from school textbooks (Lebedev 1892: 42-43), but in the 19th century this information was increasingly drawn from the press, where cold often served as an epithet for Siberia. Siberia was the cold land (J. L. 1897: 1; Nigol 1918: 40), the land of harsh climate (Postimees 1897: 1), the harsh cold land (Olevik 1897). Cold snowy winters is a subject that added weight to the articles about Siberia, confirming the customary image of Siberia. The snowiness of Siberian winters is described by Meinhard Mühlenberg, a schoolteacher in an Estonian settlement in Western Siberia: "Instead of buildings you can see huge snowdrifts with smoky-black openings, which show that people live in those snowdrifts" (Mühlenberg 1884: 174). The Estonian settlers in Siberia described their new homeland in the letters that they sent to Estonia. Some of these letters were published in Estonian newspapers. The settlers wrote about severe winter storms, the burans, as well as the ground that was frozen to the depth of up to ten feet, and the crevices in it (H. Kr. 1915: 2). Also, the comparisons with Estonian climate had a significant importance. The settlers wrote that in Siberia winters were colder than in Estonia, without being damp (Lukk 1908: 3).

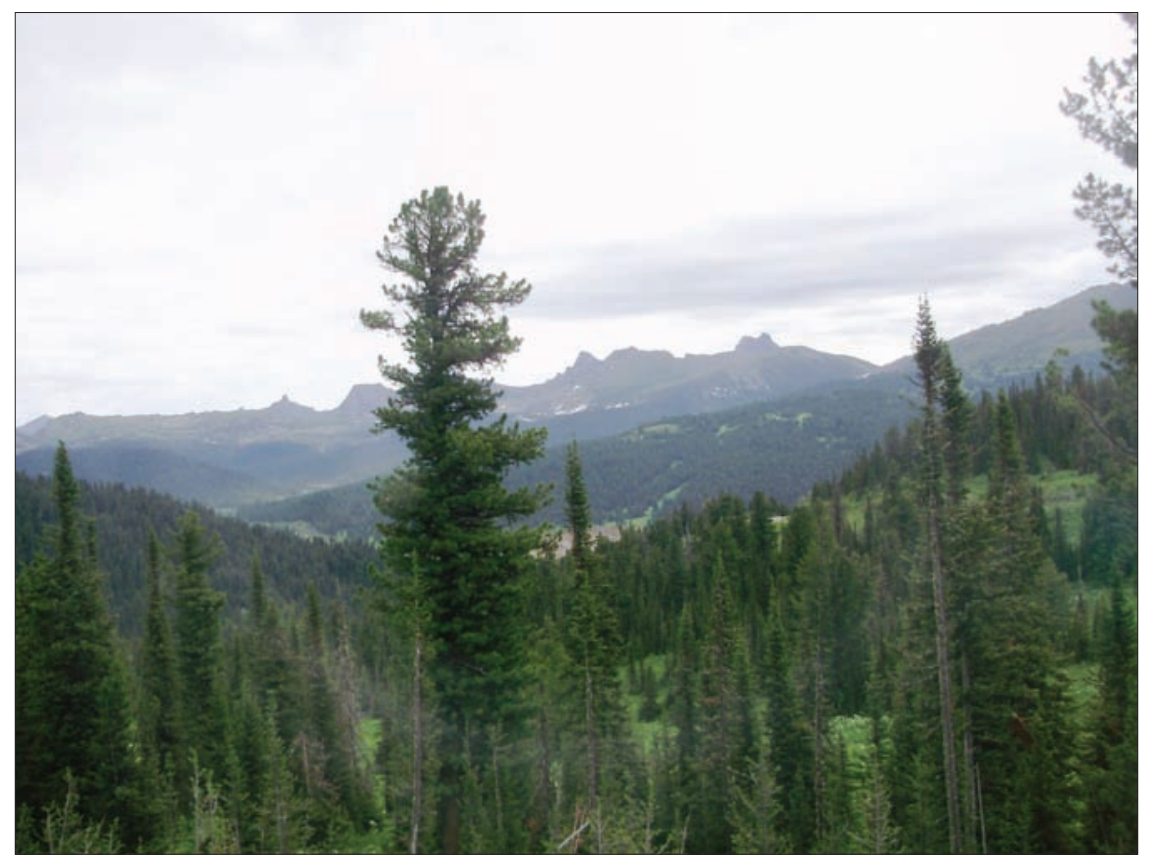

Figure 1. Taiga in Siberia. Photograph by Aivar Jürgenson 2010. 
Siberia is cold, but it is also wild. The clichés about Siberia used in the texts reflect this aspect of the image of Siberia to the extent that Siberia and the forest are inseparable. Siberian forest is a metaphor and a concept with a definite meaning, just like a bottomless hole swallowing Estonians forever. Siberian forests really seemed like another world to the settlers, like something inhuman and strange. "Here in a parish you can find such a primeval forest - the taiga - which no one has ever entered" (Postimees 1899: 2).

The impenetrable forests on the one hand and the vastness of the territory on the other are images that often stand side by side, providing a double description of the novel conditions in Siberia. The boundlessness of Siberia gives it a tingle of gloom: "Thus our brothers and sisters are lost just like behind the clouds and under the ground" (Sakala 1894a: 3-4).

Siberia's forest metaphor has a double meaning. On the one hand, there are writings on how volunteer Estonian settlers established a home for themselves by creating fields "of the Siberian forest by toiling that has become dear" (Asutawa Kogu protokoll nr. 13: 476), or in a mythological sense brought culture out of chaos. Here the forest symbolises the Great Opposer as a force of nature: the binary opposition is created by culture and nature. However, when somebody writes about Estonian deportees struggling in Siberian forests as Stalin's slaves (Väinjärve 1942: 31), then the symbol of the Siberian forest supports not only the natural aspect but also the political-historical one.

An essential part of the image of Siberia is also the image of a Siberian. Just like wilderness and enormous size are important components of the Siberian image, an inhabitant of Siberia is also wild and big. Climate-theoretical accounts on the impact of Siberian natural environment on the character and physical attributes of its inhabitants can be found in the treatments by Siberian 19thcentury regionalist literati (Jadrinzew 1886: 62; see also Anisimov 1999: 21ff.), but also from contemporary Siberian writers (Andyusev 1996, 1997; Rasputin 1987: 135-136). According to them, the Siberian inhabitant is forceful and crude, sometimes a wild person with a broad spirit and a sense of closeness to nature. Just as Siberia itself is vast and wild, so is the Siberian.

The Estonians who were deported to Siberia in the 1940s and came into contact with local people also described Siberians according to the earlier stereotypes. The descriptions include elements that show the Siberians as powerful and robust: "The hosts are a family of big, strong people with wide Siberian jaws" (Kivik 1996: 47). In such descriptions, the stereotypes of Siberian nature are ascribed to the people of Siberia as well.

An important aspect in the image of Siberian nature is its fauna; first and foremost, bears that have become one of Siberia's symbols. Meeting the bears, descriptions of bear hunting and introducing famous bear hunters are frequent 
motifs in Siberian travelogues (Kohn \& Andree 1876: 188; Messerschmidt 1962: 282; Bergman 1926: 195; Hultén 1926: 210). At the beginning of the 20th century, the Estonian press also published letters from Siberia about how the woods were crawling with bears and how the bears lurked around in villages (Nieländer 1909: 2). Stereotypes founded on such stories have persisted even through the later decades.

When in the autumn of 2000 an Estonian language teacher was sent to the Verkhnii (Upper) Suetuk village school in Eastern Siberia, the Estonian media covered the event extensively. One of the authors wrote how the teacher's friend expressed an opinion that, while living in Siberia, the teacher would have to learn to hunt bears (Korv 2000).

In the interviews that I carried out with Siberian Estonians, bears were a frequent topic. On the one hand, Siberian Estonians try to ridicule the image that the rest of the world has about how bears roam the streets in Siberia. On the other hand, they find ways to use the bear as a symbol embodying the wildness of Siberia as a tool for self-identification. If Siberian Estonians call themselves Siberi karu (Siberian bear), they do it with full self-consciousness (see Jürgenson 2003: 135; 2006: 148ff.), and with that they confront the rest of the world, including Estonia. This symbol is strong and suits well into the given context: although in the Estonian auto-stereotype the forest is also important (i.e., Estonians as forest people, see Hiiemäe 1997: 29; Jõgisalu 1997: 69), but a bear as an identifier is of no significance.

Associating Siberia with bears is a universal phenomenon. A headline in the Estonian newspaper Postimees, "The Siberian Bear Karelin Loves Rakhmaninov and Dostoyevsky" (Kees 2003), is expressive on several levels: the giant wrestler as an embodiment of a giant of nature or a savage in an absurd-like connection with high culture: contrasting the wild Siberia and the cultural world serves as a background to this association. The Siberian bear is a symbol that has evolved through centuries and is connected with historical semiotic processes, the identity of Siberia and Siberians (see Jürgenson 2003: 135-137).

Considering the Siberians as people close to nature is a part of the image that Siberia has been attributed by the outside world. This stereotype has been presented both by Russian and Western authors (especially in travelogues) throughout several centuries. But at the same time it is the auto-stereotype of Siberians, initially produced by the Siberian regionalist literates of the 19th century, who were trying to find in it a contradistinction with the Russians from Russia. The stereotype that was produced as a conscious contradistinction and a marker of an ethnic boundary has later been ingrained also in the inhabitants of Siberia and contributed to the formation of the local identity of Siberia. In addition, the Estonians from Siberia use this as an auto-stereotype. 


\section{SIBERIA AS A LAND OF ENDLESS POSSIBILITIES: VOLUNTARY EMIGRATION}

It may feel paradoxical, but although Siberia has been the carrier of mainly a negative wild image, for many it has also been a promised land, Elysium. While during several centuries trains with prisoners moved towards Siberia, there have always been those who have voluntarily escaped to this region, fleeing from landlords, etc. As a result of the 1650s schism, many Old Believers escaped to Siberia from persecutions. Throughout hundreds of years, artisans, traders, peasants and deserted soldiers have come to Siberia. In addition, after the abolishment of serfdom in 1861, an extensive emigration movement started in Russia, with one of the biggest waves arriving in Siberia. During the years 1896-1914, 80\% of Russian emigrants moved to Siberia (Goryushkin 1991: 140). Also from the Baltic countries a wave of emigrants reached Siberia during the last decade of the 19th and the first decade of the 20th centuries. For Estonians this was the most extensively used direction of emigration (see Kivimäe 1981: 68-69; Kulu 1997: 99). These were people who hoped to create a new future in Siberia for themselves and their offspring.

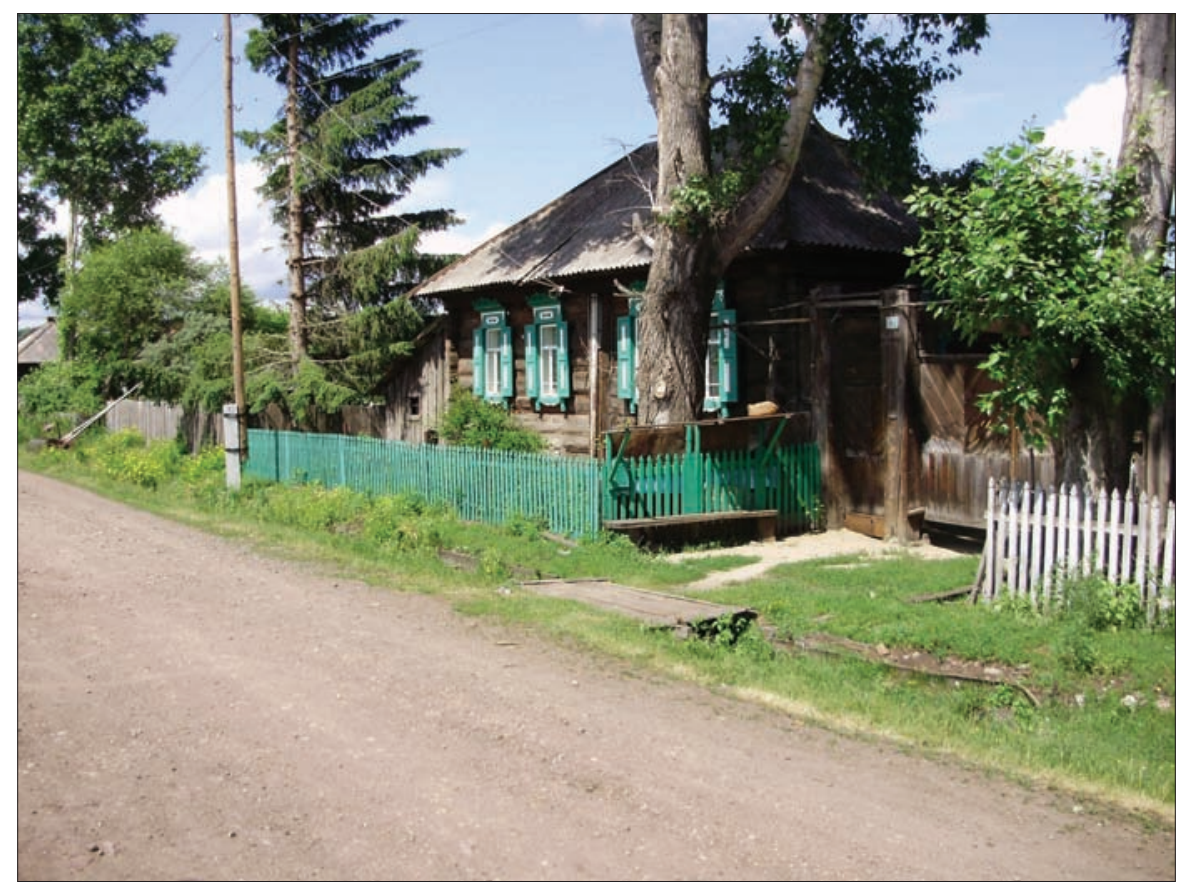

Figure 2. Estonian village Verkhnii Suetuk in Siberia. Photograph by Aivar Jürgenson 2010. 
The connection with future and freedom has given many authors who write about Siberia a good reason to associate Siberia with America, another land of future and freedom (see Petri 1886: VI; Heller 1930: 246; Snow 1977: 30; Wood 1991b: 1, 15; Lincoln 1996: 302). The basis for comparison is usually the relative newness of colonisation in both America and Siberia, and, due to that, small population, wealth of natural resources and their negligible exploitation. The authors have also compared rapidly growing cities in both America and Siberia and made observations of the mentality of people in both regions. The image of Siberia as a land of the future and its great possibilities were vastly exploited by the Estonian press at the end of the 19th and beginning of the 20th centuries. On the one hand, these were propagandistic writings, which aimed to persuade people to move to Siberia, including writings by the Estonian settlers who had already moved to Siberia and hoped to attract more compatriots to come to live with them in their settlements. Nature descriptions often reflect economic interests:

In the location of the Estonian settlement here [...] the landscape is very beautiful, the land is fertile, there are many grasslands and that is why cattle-growing is a success here. (Olevik 1893: 9)

A river rich in fish flows through our settlement. In this place the land is covered with black topsoil (chernozem) and it is fertile, if cultivated. (Olevik 1903: 274)

The countryside here is really very beautiful; especially in May and June the landscape is so wonderful that in Estonia you cannot find such even in flower gardens or manor greenhouses. Several hundreds of sorts of roses, peonies and other flowers are blooming everywhere, swaying and waving like a sea of flowers in the wind. (Sakala 1910: 2)

On the other side, the perspective of Siberia as a land of great opportunity was used in Estonian writings that served to warn people. These very same supposedly grand opportunities were ridiculed via exaggerated caricatures. For instance, the prospect of colonising Russian Far East was treated with irony:

The Yellow Sea is yellow from gold and all of the fish are by the shore. All you need is a certificate from the municipality attesting to the fact that you can hook a worm on to your fish hook. The Yellow Sea abounds in different fishes and one could even catch them with a bag [...] And the crawfish are a hundred times bigger than in the old River Raudna. One crawfish is as big as the bottom of a riddle and has a hundred chelipeds. (Postimees 1904: 2) 
The Estonian press reminded people to be careful and not to rush into the unknown, but these instances of irony also provide evidence of the fact that the peasant who left the homeland did so mainly due to economically pragmatic goals and bright hopes for the future.

The image of Siberia as a land of great opportunity has survived all the way through the 20th century until today. The offspring of original Estonian settlers still reflected on this in the interviews that I conducted with them (Jürgenson 2006: 119-120). Siberia is depicted first and foremost as a fruitful land where hard-working people can prosper. Both associating Siberia with the wild nature and the image of Siberia as a land of future have helped to strengthen Siberian regional identity.

\section{SIBERIA: A PLACE AS A CULTURAL CONSTRUCTION}

Siberia is a cultural construction: a location of not only ideas, but of embodied practices that shape identities. The understanding of space and place is created through social relations. Place is a particular articulation of social relations, a particular moment in those networks of social relations and understanding. It is clear that for those two groups - voluntary emigrants of the 19th century and the deportees of the middle of the 20th century - Siberia symbolises completely different things. No wonder that for the forcibly deported ones, the land usually remained strange, no wonder that most of the deportees returned to their homeland after they had been granted amnesty. The ones for whom Siberia was a home, assess the region and its components in a positive light. This could be exemplified by how different people with different backgrounds see Siberia, including its nature. It is clear that nature is a reflection of social and cultural experiences: when describing nature, it becomes obvious what kind of "glasses" someone wears, i.e., what is their favourite reference framework like, in which they place the symbolic objects or the landscape.

The following is a description of the homeland's nature by a woman who is a descendant of voluntary settlers:

Even that fog, when it starts emerging from the mountains - well, that I like very much. You as if step into milk - or, I cannot even say, this is so fantastically nice and beautiful. And those little flowers, how they grow there [...] And the mountains! And the strawberries that are there! (Jürgenson 2006: 162)

A deportee from Estonia, who was taken to Siberia in 1941, writes:

When the scary size of the mountain range and sulky strictness was followed by colourless wetlands and lowlands plagued by water with its 
clay huts and undisguised poverty, then we all knew that it was Asia and Siberia that was surrounding us now over there... (Kaup 1963: 30)

Yes, Siberia was strange, far away, cold and hostile, and had the impression of the land of the dead for the deportees. Sacral topography described this land as becomes obvious from the extract - as a land on the other side, i.e., as hell. This cliché had developed already earlier, under the influence of the prison camps during the tsarist period in Russia (see Grant 1993: 229), and now it acquired a deeper meaning. From the same author comes also the following vignette with a negative power of suggestion:

Dreary forests that reached the waterside, at times to the brinks, scared us. The jet-black shadows of the forest made us timid the same way as the merciless fists of the death that was waiting for us right behind the next bend of the river. (Kaup 1963: 48)

It is clear that these two descriptions stem from different positions. For both of them, Siberia has a symbolic meaning, but these meanings are different. It may feel as if the word Siberia lives its independent life and feeds on the employed stereotypes. At least for a whole century, this contradiction has characterised the image of Siberia and the reception stemming from this.

During the past century, Siberia presented at least two faces: one of them looked into the past and saw chains and barbed wire, while the other looked into the future and saw swaying cornfields and huge herds of cattle. This paradox is even further deepened by the fact that both forced and voluntary emigration headed mainly for southern Siberia: the villages of both the deportees and voluntary emigrants are situated side by side in the south of Siberia, where there are areas of fertile black soil and a benign climate. Also the 1940s deportations from the Baltic states took people to places with villages of voluntary emigrants: the homes of those who had, in their time, arrived in Siberia as Elysium. Siberia is too vast to be ascribed only one meaning to, and too multifaceted to be associated with only one emotion or opinion.

\section{CONCLUSION}

On the one hand, Siberia had become a country for deportations that injected fear in people, and, on the other hand, it presented an opportunity to escape from oppressive economic conditions in the European part of the Russian empire, a possibility of freedom.

For the Baltic nations Siberia mainly signifies a land of violence. The reason for it is the deportations carried out in the 1940s. But as we saw above, Siberia has also other stereotypes that have come into existence during different times 
via different ways. Together they have formed a heterogeneous and controversial image of the region.

The image of Siberia has been shaped by different historical events: deportations that took place during different periods of history (Tsarist Empire, Soviet period), the waves of voluntary migration, Siberia's natural conditions and physical parameters. The stereotypes of Siberia have been mediated differently. In this article I looked at how Siberian stereotypes have been presented and mediated through writings in Estonian, with comparative international material as well as segments from interviews with Siberian Estonians. According to the examples in this article, three main themes emerge in the image of Siberia:

1. Violent past of Siberia - the land of deportations;

2. Siberian nature - Siberia as a cold, vast and wild land;

3. Siberia as a land of future and endless possibilities.

In the 19th century Siberia was well known among Estonians as a destination for deportations. During the second half of the 19th century, Estonian newspapers published numerous writings about the deportees and their living conditions. At the end of the 19th and beginning of the 20th centuries, a socially critical dimension was added: the people who had been forcefully sent to Siberia were beginning to be portrayed as innocent victims of state-inflicted violence. This aspect in the image of Siberia grew more pronounced because of the mass deportations in the 1940s, which were carried out during the Soviet regime, and has persevered until today.

Not as clearly etched out, but still a significant stereotype of Siberia, is associated with nature: Siberia as a cold, vast and wild land. The metaphor "Siberian cold" was first introduced into Estonian press in the 1860s and has survived until today. The image of Cold Siberia has not been damaged by the fact that summers in the south of Siberia are warm enough for growing watermelons and grapes. The wildness of Siberia is connected with its nature: throughout a century writings have been published that speak about Siberian great vast forests as well as the animals that live in them. The metaphor for the Siberian forest has a double meaning: we saw that, on the one hand, it fits into the binary opposition culture versus nature; on the other hand, the forest symbol of Siberia can also contain, in addition to the natural aspect, a politicalhistorical aspect. In that case the Siberian forest is not a symbol of a natural chaos that human effort can mould into culture, but a symbol of violence inflicted by the state on its own people.

The third stereotype - Siberia as a land of infinite possibility and a land of the future - originated in the end of the 19th and beginning of the 20th centuries. This stereotype is mostly affiliated with the voluntary colonisation of Siberia that in Estonia lasted from the end of the 19th century until the First World 
War. This stereotype is on one level in conflict with the two ones described before, and is therefore not especially widespread in Estonia. A positive image of Siberia in Estonia is carried by the members of the so-called Siberian Estonian community: the children of former settlers who were born in Siberia and for whom Siberia is their homeland. For them the image of Siberia as a country of wild nature and Siberia as a land of the future form a unitary whole: both these images help to create the local identity of Siberia.

\section{ACKNOWLEDGEMENTS}

Research for this article was supported by research project SF 0130038s09 and ETF 9066.

\section{NOTE}

1 In practice it is hard to differentiate between prejudice and stereotype, which is why in social psychology these terms are used almost interchangeably (Matthes 1981: 23).

\section{REFERENCES}

Andyusev $1996=$ Andiusev, Boris. Likhoi chelovek v ledianoi pustyn'e. [An Insolent Man in Icy Desert.] Newspaper Krasnoiarskii Rabochii, Nos. 144/145, August 3, p. 9. Andyusev 1997 = Andiusev, Boris. Dosug i prazdniki sibiriakov. [Leisure and Holidays of the Siberians.] Newspaper Krasnoiarskii Rabochii, Nos. 242/243, December 20, p. 10.

Anisimov 1999 = Anisimov, K. Sibirskii oblastnicheskii roman: ot "Taizhan" k "Churaevym". [The Siberian Regionalist Novel: From "Taizhan" to "Churaev".] Filologicheskie stranitsy, No. 1, pp. 20-29.

Asutawa Kogu protokoll nr. 13. Eesti Asutaw Kogu (19. mai 1919). [Protocol No. 13 of the Constituent Assembly. Estonian Constituent Assembly (May 19, 1919)]. Available at http://www.digar.ee/arhiiv/et/raamatud/8472, last accessed on June 4, 2014.

Bergman, Sten 1926. Vulkane, Bären und Nomaden. Reisen und Erlebnisse im wilden Kamtschatka. Stuttgart: Strecker und Schröder Verlag.

Blumberg, Gustav 1874. Juhataja Kodu- ning isamaa tundmisele. [Guide to the Knowledge of Home- and Fatherland.] Tartu: H. Laakmann.

Burke, Peter 2001. Eyewitnessing: The Uses of Images as Historical Evidence. London: Reaktion Books.

Cochrane, Dundas J. 1825. Fussreise durch Russland und die sibirische Tatarey und von der chinesischen Grenze nach dem Eismeer und Kamtschatka. II Teil. Wien: Anton Strauss Verlag.

Cyrus, Norbert 2001. Stereotypen in Aktion: Die praktische Relevanz nationaler Schemata für einen polnischen Transmigranten in Berlin. In: Klaus Roth (ed.) Nach- 
barschaft: interkulturelle Beziehungen zwischen Deutschen, Polen und Tschechen. München \& Berlin: Waxmann, pp. 165-196.

Finsch, Otto 1879. Reise nach West-Sibirien im Jahre 1876. Berlin: Verlag Erich Wallroth.

French, R. A. 1989. Introduction. In: Alan Wood \& R. A. French (eds.) The Development of Siberia. People and Resources. Hount Mills \& Basingstoke \& Hampshire \& London: Macmillan, pp. 1-10.

Goryushkin, Leonid 1991. Migration, Settlement and the Rural Economy of Siberia, 1861-1914. In: Alan Wood (ed.) The History of Siberia: From Russian Conquest to Revolution. London \& New York: Routledge, pp. 140-157.

Grant, Bruce 1993. Siberia Hot and Cold: Reconstructing the Image of Siberian Indigenous Peoples. In: Galya Diment \& Yuri Slezkine (eds.) Between Heaven and Hell: The Myth of Siberia in Russian Culture. New York: St. Martin's Press, pp. 227-253.

Griffin 1987 = Griffin, Garol'd. Krai, ozhivshii pri sotsializme. [Region Coming to Life in Socialism.] In: Sergei Ostroumov (ed.) Sibir: kakoi ee vidit mir. [Siberia: How the World Sees It.] Irkutsk: Vostochno-Sibirskoe Knizhnoe Izdatel'stvo, pp. 93-102.

Heller, Otto 1930. Sibirien, ein anderes Amerika. Berlin: Neuer Deutscher Verlag.

Hiiemäe, Mall 1997. Metshaldjad ja muud üleloomulikud olendid metsas. [Forest Spirits and Other Supranatural Beings in the Forest.] In: Rein Ahas \& Hendrik Relve (eds.) Mets ja kultuur. [Forest and Culture.] Tartu: Eesti Roheline Liikumine, pp. 29-35.

Hinrikus, Rutt (comp.) 1999. Me tulime tagasi. [We Came Back.] Tartu: Eesti Kirjandusmuuseum.

H. Kr. 1915. Eesti asundusest. Loodus ja elu Siberis Omi Eesti asundustes. [About Estonian Settlement: Nature and Life in Om Estonian Settlements in Siberia.] Newspaper Tallinna Teataja, No. 172, July 31, pp. 2-3. Available at http://dea. nlib.ee/fullview.php?pid=s210732\&nid=22191\&frameset $=1$, last accessed on May 14, 2014.

Hultén, Eric 1926. Ins Innere Süd-Kamtschatkas. In: Sten Bergman (comp.) Vulkane, Bären und Nomaden. Reisen und Erlebnisse im wilden Kamtschatka. Stuttgart: Strecker und Schröder Verlag, pp. 200-232.

Jadrinzew, Nikolaj M. 1886. Sibirien: geographische, ethnographische und historische Studien. Bearbeitet von Ed. Petri. Jena: H. Costenoble.

J. L. 1897. Siberist. [From Siberia.] Newspaper Postimees, No. 222, October 3, p. 1. Available at http://dea.nlib.ee/fullview.php?pid=s917626\&nid=1058\&frameset=1, last accessed on May 14, 2014.

Jõgisalu, Harri 1997. Loodusest lastele. [About Nature to Children.] In: Rein Ahas \& Hendrik Relve (eds.) Mets ja kultuur. [Forest and Culture.] Tartu: Eesti Roheline Liikumine, pp. 65-70.

Jürgenson, Aivar 2003. Üks väikestest Eestidest: Siberi eesti sümbolid. [One of the Small Estonias: The Symbols of Siberian Estonia.] In: Aivar Jürgenson (ed.) Aeg ja Lugu: Esseid eesti kultuuriloost. [Time and the Story: Essays on Estonian Cultural History.] Tallinn: Ajaloo Instituut, pp. 129-142.

Jürgenson, Aivar 2006. Siberiga seotud: eestlased teisel pool Uuraleid. [Connected with Siberia: Estonians across the Urals.] Tallinn: Argo.

Jürgenson, Aivar 2008. Siber-vabaduse ja vangiahelate vahel. [Siberia: Between Freedom and Shackles.] Tallinn: Argo.

Kaczýnska, Elźbieta 1994. Das grösste Gefängnis der Welt: Sibirien als Strafkolonie zur Zarenzeit. Frankfurt \& New York: Campus Verlag. 
Kaup, Johannes 1963. Hauatagune Siber. Maria Jürvetson’i-Jürimäe elu-ja surmakirju ristilöödud elu maalt. [Sepulchral Siberia: Maria Jürvetson-Jürimäe's Letters from the Land of Crucified Life.] Geislingen: Industrie-Druck GmbH.

Kees, Tõnu 2003. Siberi karu Karelin armastab Rahmaninovi ja Dostojevskit. [The Siberian Bear Karelin Loves Rakhmaninov and Dostoyevsky.] Newspaper Postimees, November 1. Available at http://www.postimees.ee/1381591/siberikaru-karelin-armastab-rahmaninovi-ja-dostojevskit, last accessed on April 24, 2014.

Kennan, George n.d. Sibirien: Nach den im "Century Magazine” erschienenen Aufsätzen. Halle: Otto Hendel Verlag.

Kiik, Heino 1988. Maria Siberimaal. [Maria in Siberia.] Tallinn: Eesti Raamat.

Kivik, Uno 1996. Isast ja meie perekonna ärasaatmisest 14. juunil, 1941. [About Father and the Deportation of Our Family.] Siberilood: Eestlaste siberiteekond ja selle järelkajad 1940-1996. [Siberian Stories: The Way to Siberia and its Reflections in 1940-1996.] Manuscript at the National Library in Tallinn, pp. 39-71.

Kivimäe, Sirje 1981. Eesti talurahva ümberasumine 20. sajandi algul. [The Migration of Estonian Peasantry at the Beginning of the 20th Century.] In: Enn Tarvel (ed.) Eesti ajaloo probleeme. [Problems of Estonian History.] Tallinn: Eesti NSV Teaduste Akadeemia Ajaloo Instituut, pp. 66-75.

Kohn, Albin \& Andree, Richard 1876. Das Neue Buch der Reisen und Entdeckungen: Sibirien und das Amurgebiet. Leipzig: Verlag von Otto Spamer.

Kolesnikov 1975 = Kolesnikov, Aleksandr. Ssylka i zaselenie Sibiri. [Banishment and Resettlement in Siberia.] In: Leonid Goriushkin (ed.) Ssylka i katorga v Sibiri (XVIII-nachalo XX v.) [Deportation and Forced Labour in Siberia (18th Beginning of the 20th Century).] Novosibirsk: Nauka, pp. 38-58.

Kopperman, Maria 1972. Minu 12 aastat Siberis. [My 12 Years in Siberia.] Stockholm: Harta Förlag AB.

Kõresaar, Ene 2005. Elu ideoloogiad: Kollektiivne mälu ja autobiograafiline minevikutõlgendus eestlaste elulugudes. [Ideologies of Life: Collective Memory and Autobiographical Meaning-Making of the Past in Estonian Life Stories.] Tartu: Eesti Rahva Muuseum.

Korv, Neeme 2000. Filoloog Piret Toomet valmistub ajas rändama. [Philologist Piret Toomet is Getting Ready to Travel in Time.] Newspaper Postimees, August 14, p. 24.

Kulu, Hill 1997. Eestlaste tagasiränne 1940-1989: Lääne-Siberist pärit eestlaste näitel. [Estonian Return Migration 1940-1989: A Case of West-Siberian Estonians.] Tartu: Tartu Ülikooli Kirjastus.

Kurier 2012 = Wetter: Sibirien lässt grüßen. Kurier, January 29. Available at http:// kurier.at/politik/wetter-sibirien-laesst-gruessen/756.344, last accessed on April 25, 2014.

Lebedev, E. A. 1982. Geograhwi õpetus walla koolidele. [Geography Textbook for Parish Schools.] Transl. by Jaan Jung. Tartu: n.p. Available at http://www.digar.ee/ arhiiv/et/raamatud/72476, last accessed on April 25, 2014.

Lincoln, Bruce W. 1996. Die Eroberung Sibiriens. München \& Zürich: Piper Verlag.

Lipp, R. 1939. Metsavargad. [Forest Thieves.] Newspaper Päevaleht, No. 182, July 9, p. 4. Available at http://dea.nlib.ee/fullview.php?pid=s224169\&nid=108432\&fra meset=1, last accessed on May 14, 2014. 
Lotman, Juri 1999. Semiosfäärist. [On the Semiosphere.] Tallinn: Vagabund.

Luiga, Georg Eduard 1912. Wägiwallamaal. [In the Land of Violence.] Tallinn: J. Ploompuu.

Lukk, Peeter 1908. Siberist. [From Siberia.] Newspaper Elu, No. 129, June 12, p. 3. Available at http://dea.nlib.ee/fullview.php?pid=s288640\&nid=6155\&frameset=1, last accessed on May 14, 2014.

Margolis 1975 = Margolis, Aleksandr 1975. O chislennosti i razmeshchenii ssylnykh v Sibiri v kontse XIX v. [On the Number and Distribution of Deportees in Siberia at the End of the 19th Century.] In: Leonid Goriushkin (ed.) Ssylka i katorga $v$ Sibiri (XVIII - nachalo XX v.) [Deportation and Forced Labour in Siberia (18th Beginning of the 20th Century).] Novosibirsk: Nauka, pp. 223-237.

Matthes, Eckhard 1981. Das Veränderte Russland: Studien zum deutschen Russlandverständnis im 18. Jahrhundert zwischen 1725 und 1762. Frankfurt am Main \& Bern: Verlag Peter D. Lang GmbH.

Messerschmidt, Daniel G. 1962. Forschungsreise durch Sibirien 1720-1727. Edited by E. Winter \& N. A. Figurovskij, Part 1. Berlin: Akademie Verlag.

Mihkelson [Tuglas], Friedebert 1906. Hingemaa. [Soul's Acre.] Tartu: Noor-Eesti Kirjastus.

Mote, Victor L. 1998. Siberia: Worlds Apart. Colorado \& Oxford: Westview Press.

Mowat 1987 = Mouet, Farli. Polet v neizvestnost'. [A Flight to Obscurity.] In: Sergei Ostroumov (ed.) Sibir: kakoi ee vidit mir. [Siberia: How the World Sees It.] Irkutsk: Vostochno-Sibirskoe Knizhnoe Izdatel'stvo, pp. 65-93.

Mühlenberg, Meinhard 1884. Lääne-Siberist. [From Western Siberia.] Newspaper Kündja, No. 15, April 11, pp. 175-176. Available at http://dea.nlib.ee/fullview. php?pid=s329498\&nid=28331\&frameset=1, last accessed on May 14, 2014.

Must, Aadu 2012. Siber ja Eesti. Jalaraua kõlin. [Siberia and Estonia: Clink of the Fetters.] Tartu: Tartu Ülikooli Kirjastus.

Nieländer, S. 1909. Kiri Siberist I. [A Letter from Siberia I.] Newspaper Rahva Päevaleht, No. 27, February 5 (18), p. 2.

Nigol, August 1918. Eestlaste asundused ja asupaigad Wenemaal. [Estonian Settlements in Russia.] Tartu: Eesti Kirjanduse Seltsi Kodumaa Tundmaõppimise Toimkond. Available at http://ida.aule.ee/raamatud/nigol1918_orig.pdf, last accessed on April 28, 2014.

Õiger, Karl 2011. Ma tulin tagasi. [I Came Back.] Tallinn: Printon.

Olevik 1893 = Siberis. [In Siberia.] Newspaper Olevik, No. 1, January 4, pp. 9-10. Available at http://dea.nlib.ee/fullview.php?pid=s385653\&nid=112344\&frames et=1, last accessed on May 14, 2014.

Olevik 1894 = Sõnumed. [News.] Newspaper Olevik, No. 39, September 26, pp. 828-829. Available at http://dea.nlib.ee/fullview.php?pid=s377010\&nid=112736\&frames et $=1$, last accessed on May 14, 2104.

Olevik 1897 = Teated. [News.] Newspaper Olevik, No. 40, October 7, pp. 894-895. Available at http://dea.nlib.ee/fullview.php?pid=s376268\&nid=113293\&frames et $=1$, last accessed on June 5, 2014.

Olevik 1903 = Eesti asunikkude elust. [On the Life of Estonians Settlers.] Newspaper Olevik, No. 12, March 25, p. 274. Available at http://dea.nlib.ee/fullview.php?pi $\mathrm{d}=\mathrm{s} 375996 \&$ nid $=118451 \&$ frameset=1, last accessed on May 14, 2014. 
Pae, Taavi 2012. Võrdnimed Eestis. [Toponyms in Estonian.] In: Jüri Metsalu (ed.) Pärimus inimese ja maastiku dialoogis. Ettekannete teesid. [Tradition in Man-Landscape Dialogue. Abstracts.] Tartu: Eesti Kirjandusmuuseumi Teaduskirjastus, pp. 3537. Available at http://www.folklore.ee/era/tk2012/TK12teesid.pdf, last accessed on April 28, 2014.

Parts, Heiki 1954. Nädalalõpumatk Colorado kanjonile. [A Weekend Trip to Colorado Canyon.] Journal Kodukolle, No. 9, pp. 9-10.

Perno Postimees 1864 = Newspaper Perno Postimees, No. 5, January 29, p. 37. Available at http://dea.nlib.ee/fullview.php?pid=s385923\&nid=10176\&frameset=1, last accessed on May 14, 2014.

Petri, Eduard 1886. Vorwort. In: Sibirien: geographische, ethnographische und historische Studien von N. Jadrinzew. Bearbeitet von Ed. Petri. Jena: Hermann Costenoble, pp. V-XIII. Available at https://archive.org/details/sibiriengeograp00petrgoog, last accessed on April 28, 2014.

Postimees 1897 = Siberisse rännanud rahva hädakorra kergituseks. [For Alleviation of the Misery of the People Migrated to Siberia.] Newspaper Postimees, No. 223, October 4, p. 1. Available at http://dea.nlib.ee/fullview.php?pid=s912674\&nid=1 060\&frameset=1, last accessed on May 14, 2014.

Postimees 1899 = Eesti asujatest Siberis. [About Estonians Settlers in Siberia.] Newspaper Postimees, No. 144, July 6, p. 2. Available at http://dea.nlib.ee/fullview.php?pid= s268261\&nid=3665\&frameset=1, last accessed on May 14, 2104.

Postimees $1900=$ Siberisse rändamise himulistele. [To the People Who Want to Migrate to Siberia.] Newspaper Postimees, No. 93, April 26, pp. 1-2. Available at http:// dea.nlib.ee/fullview.php?pid=s246489\&nid=5230\&frameset $=1$, last accessed on May 14, 2014.

Postimees 1904 = Eesti asunikud kaugel Idas. [Estonian Settlers in Far East.] Newspaper Postimees, No. 98, May 3, pp. 1-2. Available at http://dea.nlib.ee/fullview.php?pi $\mathrm{d}=\mathrm{s} 287769 \&$ nid $=2382 \&$ frameset $=1$, last accessed on May 14, 2014.

Postimees 1932 = Vabatahtlikkude "Siber". Alutaguse metsa- ja kraavitöölistest. [The „Siberia“ of Volunteers: About the Loggers and Ditch Diggers of Alutaguse.] Newspaper Postimees, No. 278, November 26, p. 4. Available at http://dea.nlib. ee/fullview.php?pid=s228524\&nid=52324\&frameset=1, last accessed on May 14, 2014.

Ranne, Raul 2000 Vabatahtlikult Siberisse. [Voluntarily to Siberia.] Newspaper Eesti Ekspress, No. 44, November 2, p. 29.

Rasputin, Valentin 1987. Sibirien ohne Romantik. Essay. München: C. Bertelsmann Verlag.

Rävälä, Annus [Tarand, Helmut] 1981. Vorkuta värsse. [Verses from Vorkuta.] Lund: Eesti Kirjanike Kooperatiiv.

Saarmaa, Triin 2000. Vabatahtlikult Siberis. [Voluntarily in Siberia.] Journal Eesti Loodus, No. 12, pp. 519-520.

Sakala 1894a = Kirjad Siberist I. [Letters from Siberia I.] Newspaper Sakala, No. 13, March 30, pp. 3-4. Available at http://dea.nlib.ee/fullview.php?pid=s228524\&ni $\mathrm{d}=52324 \&$ frameset $=1$, last accessed on May 14, 2014 .

Sakala 1894b = Kirjad Siberist II. [Letters from Siberia II.] Newspaper Sakala, No. 15, April 13, pp. 3-4. Available at http://dea.nlib.ee/fullview.php?pid=s289756\&nid $=16993 \&$ frameset $=1$, last accessed on May 14, 2104 . 
Sakala 1910 = Eesti asunikud. [Estonian Settlers.] Newspaper Sakala, No. 11, January 29, p. 2. Available at http://dea.nlib.ee/fullview.php?pid=s910970\&nid $=20001 \&$ frameset $=1$, last accessed on May 14, 2014.

Schultz, Joachim Christoph Friedrich 1795/96. Reise eines Liefländers von Riga nach Warschau, durch Südpreußen, über Breslau, Dresden, Karlsbad, Bayreuth, Nürnberg, Regensburg, München, Salzburg, Linz, Wien und Klagenfurt, nach Botzen in Tyrol. 3 vols. Berlin: Friedrich Vieweg.

Silliksaar, Silver 2001. Sinasilmitsi Siberiga: Mälestusteraamat 1951. aasta küüditamisest. [Facing Siberia: Memories of the 1951 Deportation.] Võru: Võru Täht.

Smitt 1987 = Smitt, Emma 1987. Chto ia otkryla v Sibiri. [What I Discovered in Siberia.] In: Sergei Ostroumov (ed.) Sibir: kakoi ee vidit mir. [Siberia: How the World Sees It.] Irkutsk: Vostochno-Sibirskoe Knizhnoe Izdatel'stvo, pp. 103-124.

Snow, Russel E. 1977. The Bolsheviks in Siberia 1917-1918. Cranbury \& New Jersey: Associated University Presses, Inc.

Spiridonova 1999 = Spiridonova, G. Motif ssylki v Sibirskoi belletristike 30-kh godov XIX veka. [The Motive of Deportation in the Siberian Fiction of the 1830s.] Filologicheskie stranitsy, No. 1, pp. 6-13.

Thomas, Ludmila 1982. Geschichte Sibiriens. Von den Anfängen bis zur Gegenwart. Berlin: Akademie-Verlag.

Väinjärve 1942 = Väinjärve valla bolshevike võimu alt vabanemise ja Omakaitse Koeru Piirk.-Pataljoni aastapäeva aktuse kava. [Programme for the Ceremony to Celebrate the First Anniversary of Väinjärve Liberation from Bolsheviks and the Home Guard Battalion of Koeru Region.] Koeru: Väinjärve valla vabastamis-aastapäeva korraldav toimkond. Available at http://digar.nlib.ee/ digar/show/?id=104920, last accessed on April 28, 2014.

Veisserik, Artur 1995. Ma armastasin Eestit. [I Loved Estonia.] Tartu: Ilmamaa.

Viitar, Aili 1990. Siberi-raamat. [Book of Siberia.] Tallinn: Eesti Raamat.

Vilde, Eduard 1896. Külmale maale. [To the Cold Land.] Jurjev: Postimees.

Vilde, Eduard 1924. Mahtra sõda. [The Mahtra War.] Tallinn: Varrak.

Walgus 1885 = Siberi maalt. [From Siberia.] Newspaper Walgus, No. 22, June 8, p. 2. Available at http://dea.nlib.ee/fullview.php?pid=s189406\&nid=211517\&frames et=1, last accessed on May 14, 2014.

Watrous, Stephen 1993. The Regionalist Conception of Siberia, 1860 to 1920. In: Galya Diment \& Yuri Slezkine (eds.) Between Heaven and Hell: The Myth of Siberia in Russian Culture. New York: St. Martin's Press, pp. 113-132.

Wein, Norbert 1999. Sibirien. Gotha und Stuttgart: Klett-Perthes.

Wood, Alan 1991a. Editor's Preface. In: Alan Wood (ed.) The History of Siberia: From Russian Conquest to Revolution. London \& New York: Routledge, pp. IX-X.

Wood, Alan 1991b. Introduction: Siberia's Role in Russian History. In: Alan Wood (ed.) The History of Siberia: From Russian Conquest to Revolution. London \& New York: Routledge, pp. 1-16.

Wood, Alan 1991c. Russia's 'Wild East': Exile, Vagrancy and Crime in NineteenthCentury Siberia. In: Alan Wood (ed.) The History of Siberia: From Russian Conquest to Revolution. London \& New York: Routledge, pp. 117-137.

Yadrintsev 1882 = Iadrintsev, Nikolai. Sibir kak koloniia. [Siberia as a Colony.] SanktPeterburg: Tipografiia M. M. Stasiulevicha. 


\title{
LATGALIAN EMIGRANTS IN SIBERIA: CONTRADICTING IMAGES
}

\author{
Sanita Reinsone
}

\begin{abstract}
The turn of the 20th century saw a large-scale voluntary emigration of Latgalians to Siberia. The descendants of Latgalian emigrants still live in the villages founded by their predecessors. In the article the author examines the image of the Latgalian emigrants created by the printed media of the period, which carefully followed the process of emigration, and explores what contemporary Siberian Latgalians tell about their antecedents, arguing that the image of the simple-minded emigrants cultivated by the local newspapers at the turn of the 20 th century contradicts the narrated image of skilful emigrants that symbolise the progressive origins of their community.
\end{abstract}

Keywords: Latgalian migration, newspapers, oral narratives, Siberia, 19th century

\section{INTRODUCTION}

Siberia as a land of great opportunities appeared on Latgalian ${ }^{1}$ agenda in the second half of the 19th century. When in 1861 serfdom was abolished on the territory of Latgale, the peasants there gained the migration right, very much the same as the peasants in the neighbouring Baltic provinces (Kurzeme, Livonia/Vidzeme and Estonia), who had been granted this freedom several decades earlier, and migration to the distant provinces of the Russian Empire afforded what so many could not achieve by staying in Latgale - to own some land. The intensity of emigration reached its zenith at the turn of the 20 th century, becoming a mass movement ${ }^{2}$ that substantially affected the demographic situation in Latgale and made migration the top issue of social discourse in the printed media of the epoch.

Data on the scale of Latgalian migration to Siberia, which continued until the First World War, vary throughout different sources. The quoted numbers of emigrants start at some tens of thousands and amount to even several hundreds of thousands, while the most recent calculations show that the number of the emigrants might have been around 50,000 people or approximately $10 \%$ of the population of Latgale ${ }^{3}$ (Kikuts 2011: 42). At the beginning of the 20th century, 
Vitebsk province (which Latgale was also a part of) is believed to have comprised one of the largest groups of Siberian emigrants from the western provinces of the Russian Empire (Kolotkin 2012: 7).

Viewed in a larger context, migration was one of the most important processes in the 19th century on the whole European scale, being caused by a rapid growth of population as well as other reasons. Massive migration from Europe to the so-called New World was one of the most important features of the evolving world economy of the 19th century (Hatton \& Williamson 1994; Baines 1995: 5). The economic migration was an issue that affected the whole of the Latvian territory already beginning in the mid-19th century. Although the system of serfdom had for a long time tied the peasants to a specific location, the emigration of Latvians falls within the same period as the great European emigrations. For the peasants of the Baltic provinces other regions of the Russian Empire were the only place where they could go, using the available means of transportation, the rights granted to them by the law, and the personal identification documents issued to them (Zelče 1999: 79).

This article attempts to look at the Latgalian emigrants of ca 1900 from two qualitatively and historically different viewpoints: first, it is the image of the emigrants to Siberia in the Latgalian printed media of the period, i.e., the image created at the time when the migration process was ongoing, and, second, the views of the Latgalian emigrants in the oral narratives of their descendants modern Siberian Latgalians. I argue that the image of the simple-minded emigrant cultivated at the turn of the 20 th century has remained encapsulated in the material of the printed media from the period, and in the view of their descendants living in Siberia the emigrants symbolise the progressive origins of their community.

\section{THE ISSUE OF EMIGRATION IN THE LATGALIAN PRINTED MEDIA OF THE TURN OF THE 20TH CENTURY}

The role of the printed media in the migration-related processes of the turn of the 20th century was a significant one: the newspapers were among the very few mass media that regularly brought the news to the community. In addition, the Latgalian newspapers not only were instrumental in bringing the information to their audience, but also actively participated in the processes taking place in society by analysing them and disseminating propaganda. The Latgalian newspapers at the turn of the 20th century became the platform of two contradictory propaganda campaigns: in favour and against the Latgalian emigration. The representation of the two stances was far from equal: 
the critique of emigration was dominating, as the heads of these newspapers, their editors and writers were representatives of the Latgalian intelligentsia, Catholic priests, teachers and men of letters, who viewed the emigration of their compatriots as a threat to the cultural and economic development of Latgale. In parallel to them, information and views on emigration were published by some anonymous authors, emigrants, their relatives and acquaintances, who had already accumulated some experience of emigration. Also, in essence, the articles are diverse: first, there are short ones, providing information on the current situation in Siberia, i.e., if there is any available land, in which district there is no land left anymore, where exactly it is available and how much, what is the quality, what are the most recent government regulations for getting land, etc. As an example, here is a fragment from an article published in 1909, entitled, To Those Preparing to Leave for Siberia:

[...] In Tomsk and Omsk districts there is no more available land left. The whole Vitebsk province is only allowed 20 lots, 30 dessiatines $^{4}$ each. There is still free land behind Lake Baikal, along the River Amur; peasants of the Vitebsk province are allowed to take some 7-8 free land lots here. (Sk. 1909: 2)

The authors who suggested migration were urging the readers to purchase the land maps that indicated the territories still available (Sākla 1906: 3). Also, the authors who aimed at keeping people from leaving, published detailed accounts of Siberian districts and villages in which Latgalians resided. Along with hindering emigration, their aim was also to promote the Latgalian unity in emigration: having learned through their articles about the districts and villages where Latgalians could be found, their compatriots were more likely to go there, instead of trying to settle in Russian villages or those of other nationalities. There were tens of such articles in the Latgalian printed media of the turn of the century, especially around the end of the first decade of the 20 th century, when the emigration fever was slowly dying down.

Second, there were articles either encouraging or discouraging the readers to undertake the lengthy journey to Siberia and other distant parts of the Russian Empire, by either promising incredible benefits or just the opposite: scaring with dangers awaiting the newcomers. Frequently information from other Russian newspapers was rendered, adding an ominous framework, e.g.: "The papers bring terrifying news from the whole of Russia [...]" (L-niks 1907: 2). The argumentation basis of the emigration proponents was thorough information: examples of the success of the emigrants ("[...] they took many lots of land, built their houses and live in prosperity [...]”) (Sākla 1906: 3); promise of a better life and the urge to seize the opportunity that might vanish soon ("Peasants! 
Act wisely and quickly, buy more land now, as the price of the land is rising by the day!") (Sk. 1909: 2). Similar slogans urging the peasants to act wisely and smartly, but, on the contrary, not to leave, were also used by the opponents of the emigration: "Compatriots, better stay at home!" (Ripa 1906: 2-3) By providing a graphic illustration of the emigrants' hardships, they urged the peasants to avoid gullibility and not to trust those who insisted that the land in Siberia was given for free, at the same time appealing to rationality and national, religious and cultural values that would be lost by submission to the emigration fever (e.g. Trasuns 1908: 3).

Third, the newspapers published epistolary accounts of the emigrants themselves, either still in Siberia or already having returned to Latgale, their relatives or other people who made these accounts public. These accounts depict the hardships encountered by the emigrants and their mood is predominantly resigned, sad and regretful.

We are scattered all over, do not see or meet one another. We have no church. For example in Achinsk district we are expecting a church to be built, but no-one is willing to fulfil our wish. The Russians are much better off: they have a number of churches. Many Latvians fade away completely, as they do not live together with the rest of the Latvians, but rather far away from the others. The government sometimes indeed attempts to mix us with the Russians, so that we would easier leave and forget our religion, our language. (Tučs 1909: 3)

The emigrants mainly complain about the poor living conditions, lack of food, intolerable weather, hard work, separation from their relatives and homeland Latgale, adding to it inaccessibility of culture and education, along with slow degradation of the religious identity caused by limited opportunities of its practicing: there are neither churches nor priests in Siberia. Such accounts of the emigrants and the general situation of the Latgalian emigration is analysed in reflexive newspaper articles, the authors of which attempt to understand the reasons of this movement, as well as their immediate and later consequences.

Along with the information distributed via newspapers, there also existed a non-documented personal communication, distributed mostly orally or through the letters of relatives or acquaintances in Siberia. Already earlier, in the 1860s, when the first Latvian emigration campaign targeted at Novgorod province, its scale was significantly influenced by the rumours about the free land lots available for a song, which spread quickly among the peasants (Zelče 1999: 80 ). In other countries as well the community's view of the destination and its image was affected by numerous factors and paths of information distribution: through meetings in taverns, fairs, and markets, outside churches after ser- 
vices, etc. (Rosoli 1993: 226). The fact that the information distributed within the Latgalian community through personal communication was probably the most influential and had a greater impact than the anti-emigration propaganda in the newspapers, can be seen from the relatively small number of articles suggesting emigration (in comparison to the large scale of emigration), as well as references to "cock-and-bull stories" about Siberia as told in Latgale in the articles discussing the Latgalian emigration (see, e.g., Svenne 1923: 64).

Latgalians' emigration reached its peak at about the time when emigration from the other parts of modern-day Latvia was already diminishing, because in Latgale serfdom was abolished later. Thus the Latgalian newspapers in essence just continued the emigration discourse started a few decades earlier in Latvian-language newspapers, which saw the acute aspirations for "one's own corner, own strip of land"5, resp. some property, and being a landowner (Latviešu Avīzes 1890: 1-2) as the reason for the Latvian peasants' endeavour to leave for the far-away lands, not as a desire to quickly and venturesomely improve their material situation. Also, in the case of Latgalians, the emigrants are mainly not the ones in deep poverty ${ }^{6}$, but those who see Siberia as an opportunity to improve their quality of life through the acquisition of a larger farm. In this aspect the profile of the Latgalian emigrants coincides with the assumption that the European emigration of the 19th century was not primarily a movement of the destitute and hopeless, but rather represented a quest for greater opportunities (Hamerow 1983: 86).

\section{HOW SIMPLE-MINDED, OH, HOW SIMPLE-MINDED IS OUR LATGALIAN PEASANT7: THE IMAGE OF SIBERIA AND THE LATGALIAN IN THE PRINTED MEDIA OF THE TURN OF THE 20TH CENTURY}

"With every new spring the old song about Siberia is renewed. Let's go to Siberia! Let's go to Tomsk! Let's go and seek a new land and new luck!" - this is how in 1910 the situation of emigration is depicted by the Latgalian newspaper Drywa (Sk. 1910: 3). The Latgalian papers at the turn of the 20th century have been preserved until the present day as one of the few witnesses of the epoch, providing us with something more than just a list of the migrants and the applications of the peasants requesting the permits to leave; these papers afford us an insight into the background of the migration discourse, showing how this movement was received in different parts of society - with prejudice, confusion and fear, myths and hope, but simultaneously also with scepticism, suspicion and disbelief. As a result of the information campaigns - one that 
was in favour and the other that was against the migration - two very bright images were created: those of the emigrant and their destination, namely Siberia. Described by using colourful epithets, metaphors and comparisons, these images worked on either side. While the proponents of emigration constructed them, then the opponents intercepted these constructions, hyperbolised and deconstructed them.

Siberia at the turn of the 20 th century had become the promised land, that of great opportunities, the saviour of the needy people aspiring to become landowners. It was the place where milk flowed instead of water, honey rained from the sky, and the crops need not have been sown at all: just let a bull to prod the soil with a horn and prepare to harvest. While the proponents tended to keep their statements low-key in order to sound credible and create a rational impression, the opponents did just the opposite: they picked the most picturesque metaphors, hyperbolising them to the absurdity:

In Siberian rivers it is not water that flows - it is milk; and it is not water that rains down from the sky - it is honey. (Ripa 1906: 2-3)

In Siberia there are hills of gold and rivers of milk. (Ripa 1907: 3)

In Siberia land is given to anyone requesting it, and that land is of excellent quality. (Lejdumniks 1907: 3)

Siberia [...] is a golden place, a place of treasures and happiness, where wine and honey flows. (Skrinda 1909a: 2)

The metaphorical rhetoric of Siberia as an idyllic land of great opportunities and peasants' happiness is characteristic not only to the Latvian printed media. Similar images and clichés have also been used in other countries from which people migrated to Siberia, e.g., Estonia, where newspapers participated equally actively in the formation of emigration discourse, using hyperbole and caricature in depicting the qualities of the destination of Estonian emigration at the end of the 19th century (Jürgenson 2002; for the experience of other countries see also Hoerder \& Rössler 1993).

As opposed to the idealised land of peasant happiness, the true face of Siberia is shown by using a contrastive approach: it is revealed as a "distant magnet", having drawn thousands to it, ruining them and forcing them to eat "bread soaked in tears" (Lejdumniks 1907: 3). The potential emigrants are warned that not everyone that hopes will happily reach the destination; one must reckon with a hard and testing journey, as was described in the articles in rather graphic scenes intended to arouse pity: miserable, ill, dying people, who jostle, swear, cry and curse, and in their midst - hungry children dressed in rags, leaving the carriages at every stop in the hope of finding some food. 
The children are getting sick especially frequently, they have to go without washing themselves for weeks, and hungry for days. The naked bodies of the children freeze and become covered in pimples from different contagious illnesses. The parents have much trouble with such ill children. Conductors and doctor's assistants are seeking such children on the train, separating them from the parents in order to send them to a hospital at the nearest train station. Clearly enough, the parents do not want to be parted from their children. They hide them under the benches, on shelves, between packages and rags, so that the "eye of the government" would not find them. Many children die on the way, unable to cope with the hardships of the travel. (Sk. 1910: 3)

The fate of those having reached the destination is no better though. They find no hills of gold and rivers of milk in Siberia. Instead, having spent all they had, the travellers find unfriendly clerks, "which we can find in great numbers in our local government institutions" (L-niks 1907: 2), inhuman weather, fully suppressing the contentment with the vastness and fertility of the land, and, last but not least, of course, inhumanly hard toil.

In summers, around noon, the sun is so hot that one can find no rest. In the evenings there are myriads of gnats and gadflies showing no mercy; when the heat reaches up to 45 degrees, one is cooked as a crayfish immediately. [...] In winter it is so cold that you meet neither a man nor a bird on the road. When the thermometer drops to 40-45 degrees, everybody is sitting at home, heating the stove continuously. Sometimes there are such snowstorms that neither the sky nor the ground is discernible. (Bycans Odums 1907: 1-2)

Contrary to this, the proponents of migration emphasise the most significant and the most pleasant to the peasant's ear: there is much free land in Siberia, it is cheap and fertile. Similar narrative strategies are used in the formation of the emigrant's profile. In the depiction of the proponents of emigration, the potential emigrant - the poverty-stricken peasant, who has to "fight his own brother for the land", and with no expectations of any change until the very end of his days - acquires a potential of activity and agility, becomes a modern man, capable of changing the conservative way of thinking, take the reins of life in his own hands and give up the safe, well-known, though modestly rewarding place in favour of future prosperity.

The described change of thinking in a community was a characteristic transformation process in different 19th century communities, a process that has also been designated as the rise of the age of individualism, for which the emigration processes were quite appropriate: a peasant severs his ties with the native 
environment, losing his social status and the guarantees it provides, becoming a free individual who takes all the responsibility for his future destiny (Zelče 1999: 79). In the hands of the opponents of emigration the same potentials of a Latgalian change completely: their Latgalian emigrant is uneducated ("simpleminded") and naive (instead of being brave and decisive), greedy (instead of oriented towards future prosperity), and incapable of reasonable actions.

[...] our greedy, impoverished, credulous Latvians started moving, preparing for the long journey, selling the lot of land they had. (Lejdumniks 1907: 3)

How simple-minded, oh, how simple-minded is our Latgalian peasant. [...] In the recent years tattered and hungry, he suffers from hunger and cold, but is unable to earn himself any income. Sometimes an opportunity for earning lies just there under his nose, but he will still not see it because of his narrow-mindedness. Show him a rouble, show him a lump of bread, and he will follow them for miles and miles, spending much more time on that than he spends earning his living. (Drywa 1909: 1)

The naivety and lack of wits is shown very demonstratively in the articles that project the typical Latgalian as finding himself under the influence of an emigration agitator. For example, the reaction of the typical Latgalian as described when telling the story of Jezups Strods from Bukumuizha, who, having returned from a short stay in Siberia to his native village, narrates to his former neighbours ("our simple-minded peasants") about the wonders of this faraway land:

Bukumuizha peasants are listening to the stories of Jezups Strods with their mouths wide open. "Vow, what a life there," says one, "Let's go there!" - "Sure, let's go. Why shouldn't we go to such a land! Do we have that kind of life here, is our soil like that?" And the wondrous stories of a happy life in Siberia told by Jezups Strods have stirred the minds of Bukumuizha peasants so strongly that all they can do is dream about Siberia, and they plan to go there in great numbers. (Ripa 1906: 2-3)

Having arrived in that foreign territory, these character traits of the Latgalian are aggravated by a still greater lack of wits and moral degradation, while it all is superseded by hardships of life unknown previously. The image of the simple-minded emigrant is also backed by the few published letters from the emigrants themselves or those who have travelled the distance to find out what the compatriots' life in Siberia is like. The conditions depicted allow for a comparison: the emigrants, full of remorse for their unreasonable decision, 
live like beasts - no school, no church, no homeland, no native tongue (see, e.g., Bycans Odums 1907: 1-2).

The educated Latgalians, opponents of emigration, who are the authors of the majority of anti-emigration articles, see the opportunities for a full-fledged, mentally and physically balanced life of Latgalians only in their native land, in Latgalian society. The educational, cultural, and religious qualities attainable here are associated with the land and the community, which cannot be transported to anywhere else; without these the emigrant is lost to his land, nation and culture. They defend the view that a person is not able to undergo a sudden change. The decision to sell all of one's property and leave will not change what they are: a lazybones will be the same, a drunkard will carry on drinking and the poor will be poor, so where is the difference - to be poor here or in faraway Siberia.

Those who think that life is hard only here, while in Siberia there are hills of gold and rivers of milk, are very wrong. [...] A poor and not too bright person will encounter difficulties everywhere; the crops grow by themselves only to those who have a thick purse. (Ripa 1907: 3)

[...] the leaving ones are lost to the nation and the church; a poor person will experience hard life wherever he goes. [...] The same hills of gold as in Siberia we can also find right here [...] First take what is lying within your reach, and only then seek for the missing in some distant place. Do not just go for a place far away because it will cost you most dearly. It is not reasonable to leave your own house and the places inhabited by your forefathers to some stranger, in order to become a traveller in a foreign place without your own homeland and language. (Trasuns 1908: 3)

What in fact encouraged the formation of this exaggerated migration discourse in the Latgalian printed media was the concern of the intellectuals for the unity of their nation, its strength and mental advancement, along with the opinion that the emigrants, by severing themselves from their land, nation and culture, harm not only themselves but also the nation, which is thus dispersed and weakened in its aspirations for mental development, subjecting itself to foreign, i.e., undesirable influence:

We do not need to run from our fatherland, instead we should take care of it; we shall buy it from the foreign hands and the nation that has only brought to us lewdness and delinquency, due to which culture is just an empty void. (Auseklis 1906: 3)

This opinion falls in line with the national identity formation processes of Latvians and other eastern and northern European oppressed nations, which 
took place at the end of the 19th century, and one of the directions of which was based on understanding the differences of a community as the foundation for a nation's unity, allowing to draw borders separating it from everything foreign, based on the inherent differences, demanding unity within the community. A nation is perceived "as a collective individual and a collection of individuals", in which everyone acknowledges their affiliation with the whole (Handler 1988: 32-39; Bula 2000: 80). Nevertheless, the appeal of intellectuals to the necessity of the nation's unity in order for it to ensure successful existence could not stop the wave of emigration, as was also admitted by Francis Trasuns, one of the most active representatives of the Latgalian intelligentsia of the time:

The propaganda and the propagandists have done their part, though. The promised hills of gold in Siberia have overcome the love to fatherland and fear of the long journey and unknown fate. Not only whole families but even whole villages have left and are still leaving for Siberia. (Trasuns 1908: 3)

With the emigration fever dying down, Latgalian intellectuals took care of the preservation of the nationality and religious life of the compatriots living far away, collecting information about the colonies formed and establishing contacts with them (Apels 1970). At the end of the first decade of the 20th century, a journey of a Latgalian Catholic bishop to the Siberian Latgalian Catholic parishes was organised, which took nearly a year and was scrupulously described in the newspaper Drywa (Skrinda 1909a-d; 1910a-b). Catholic priests are sent to the larger colonies, to support the religious and social life of the emigrants, as with the arrival of these priests churches are built and both the cooperation intensifies and ties are strengthened between the less distant Latgalian villages.

\section{IN THE OLD DAYS THERE WAS EVERYTHING. NOW NOTHING IS LEFT: SIBERIAN EMIGRANTS IN THE ORAL NARRATIVES OF THEIR DESCENDANTS}

Timofeyevka was among the largest colonies established in Siberia at the end of the 19th century by emigrants from Latgale; shortly after its foundation there were slightly over 500 inhabitants in it. Also today this village with its population of ca 170 people, situated in the Vengerovsky district of Novosibirsk Oblast, is among the largest Latgalian villages in Siberia (Mežs 2011: 71). This chapter is devoted to the oral narratives of the modern-day inhabitants of Timofeyevka about their predecessors and the origins of the village, and examines what happened to the image of the simple-minded/progressive emigrant in a modern situation. Is it still topical? If not, then what has replaced it and what 
the descendants of the emigrants tell us about their predecessors? The material used is oral interviews conducted with the inhabitants of Timofeyevka, recorded during two fieldwork sessions in 2004 and 2006 by the researchers of the Institute of Literature, Folklore and Art, the Archives of Latvian Folklore, and the Faculty of Humanities of the University of Latvia. During this field study, conversations with the inhabitants of Timofeyevka were not deliberately aimed at studying the founders of the village and the corresponding period. They cover quite a wide thematic range, discussing numerous topics of personal and social life, culture and ethnography, as well as historical and religious issues. Nevertheless, the narratives relating the origins of the village seem special in the context of all these stories. These are stories of a historically and geographically significant experience of the community: its origins, the roots of the Timofeyevka inhabitants, their sense of identity, and the formation of their common lived space (Berdoulay 1989: 130).

The past is the dominant tense in all the conversations held with the people of Timofeyevka, though also present and future are reflected in them. The stories of the past add one more dimension to the village; they mark places, people and actions, making them more lively, manifold and deeper; they serve as an introduction to the present and our contemporaries. Placing of the past in a seemingly foreground situation is encouraged by the context of the conversational situation: interviewers are interested in history, culture, traditions, everyday life of the village and the community, along with the lives of the informants and the stories about them. Also, the people of Timofeyevka like to browse their memories and talk in great lengths about the bygone days. The past is a contrast to and a nostalgic expression of the present discomfort, as characterised by the frequently presented description: In the old days there was everything. Now nothing is left (Vera Savenko). This nostalgic mood of the past arouses contradictory emotions. Memory narratives of the better times and events in the village and the informants' lives are accompanied by joyful and energetic delight, while the description of the present situation is harsh and full of remorse.

The nicest memories show two childhoods: the origins of the village and the days of childhood and youth of the narrators themselves. The informants in their story worlds become children eager for their grandmothers' tales, young, strong and active villagers as they remember themselves from the past. The village flourishes, becomes active and youthful. The predecessors of the informants the old Latgalians - are not simple-minded and credulous, as is shown in the articles of the turn of the 20th century that depict emigration. They are not only newcomers, but also the grandparents of the modern older generation of Timofeyevka, who work skilfully and lead their economies, are aware of ancient 
wisdom, celebrate their festivities and build a church. The childhood of the oldest generation of the modern people of Timofeyevka is the touching point of ages. While they were children, they got to know the first Latgalians who were as enterprising as to move to the faraway land, and they have preserved emotionally warm memories of these people.

Unequivocal positivism creates the feeling of idealisation of the age and the people. It is accompanied by the contrasts in the mood: realisation of the loss and regret about the insufficiency of the present compared to the past (Dickinson \& Erben 2006: 224; Wolf-Knuts 2003). The contrasts of ages permeate the narratives of the people of Timofeyevka, becoming their most pronounced characteristics. The contrasts unite the ages in the lives of the narrators and the village and they change the lived space: the village that was once the centre of social and economic activity is deserted, overgrown and sunk into idleness and unemployment. Now there is nothing - again and again it is repeated by the villagers who live with the past in their hearts.

Due to associations and thematic transitions, the narrators jump from one period to another, mentioning and emphasising events significant for Timofeyevka and themselves, or the ones that in the course of the conversation suddenly emerge as worthy of being told. Different ages stand side by side, as well as people of different generations and the related events. They form a peculiar collage of recollections and events with a particular emphasis on collective experience. The narrator, contrary to expectations, seldom becomes the main hero and centre of the events. 'I' remains secondary or does not appear at all, creating an impression that the narrator is the voice of the community, having assumed the role of the village's representative.

Modern people of Timofeyevka have heard about the foundation of the village mainly from their grandparents, and more rarely from their parents. In comparison to the depiction of other epochs in oral narratives, memories of the origins of Timofeyevka are rather negligible, and in the conversation these are not expanded into large narratives with an elaborate plot. In the narrations about giving in to the temptation of the free land, the predecessors' long journey across the whole of Russia and the beginning of a new life in distant Siberia are reflected as a brief sequence of events and separate personal episodes, as memorised from the stories of grandparents or parents.

- Where were your ancestors from, don't you know?

- I do not know that.

- But when did they come to Siberia?

- Once, once upon a time my mother told me that she was from some Vitebsk province. Mother. She was eleven when she was brought here. That's what she told us. (Vera Kalugina) 
- What was said about the olden days? When did they first arrive here?

- Who the heck knows that! Well... From Latvia they came. Someone was

the first to found Timofeyevka. But I do not know who it was.

- Wasn't it said who the first was?

- No, we didn't show much interest. They were rather old already. And I

didn't ask my mother. Somehow... I never asked. (Vera Savenko)

Both of these fragments of conversations show a typical situation: the informants do know where their predecessors came from, but that is about it. A more detailed narrative would not be formed, and the topic of the first arrivals is substituted by some other. Most of the stories by the people of Timofeyevka related to the arrival of their predecessors in Siberia have a common trait: they are very brief and told evidently as generalised experience stories. An impression is created that the recollections of the newcomers have been preserved until our days in some collectivised form. Personal events and similar though still different experiences have lost their individuality in the course of a century, with the stories of the arrival merging and forming something resembling a collective story of the foundation of the village with a simplified line of plot and the emphasis on the most important - the motif, action and its result. These stories resemble local legends, in their reflection of the experience or events that are connected to a community or its surroundings, and are important to the members of that particular community (Butler 1990: 44). In 2004, a simplified and laconic version of the village foundation story was told by Konstantīns Kravalis, mentioning the motif of emigration and founding of the village:

There was no land! There was no land! And then this whole village here emerged, and the trees were cut down and floated down the river. A raft comes; one builds a house and lives there.

The laconic expression of the informant and his linguistic economy fits the most important information about the emigration and the founding of the village into these very few sentences. The twice repeated There was no land! reflects the heavy problem of the particular history period - the lack of available land. A story of emigration and founding of the village was also told by Viktoria Ruduša, an informant interviewed several times during both of the fieldwork sessions.

There was no land to live on. And why did the Latvians come here? The Latvians... This land here was empty, there was nothing on it. The Tatars had once lived here. But then our Latvians came, worked the land, settled by the river. The first that moved here, they say: "Nice! There is all the land one needs, you can sow however much you like!" So, everyone rushed 
here. Both sisters and brothers started arriving. All these people came and built the Latvian village.

The story emphasises the spatial aspect: the empty space chosen by the Latgalians (empty land, i.e., non-cultivated land) is tamed, furnished and converted into a place of work and living. Viktoria also makes references to personal propaganda mentioned in the previous chapter of the present article. In the stories of generalised experience, which level down the individual experience and reveal the events and the community as an integrated whole in a co-ordinated activity, the Latgalians arrive, work and build a Latgalian village. The problems of the situation are retained in the stories that share personal memories. A few moments later in the same conversation Viktoria, when asked from where her ancestors had come, manages to remember what her grandmother had once told her:

My mother Dārte came from Latvia. She lived somewhere near Rīga. In a hamlet. My mother Dārte told me that her sister had come here first. Here she got married. And then asked her to come as well, and my mother Dārte was wed by Donats. He had also come from the Latvian land.

In conversations with Viktoria regarding the time that Timofeyevka was founded, one can hear constant references to the stories told by her grandmother Dārte. She is the informant's authority in this regard. Although such threads of recollections can hardly be called "stories", it is still obvious that along with the previously demonstrated generalised version of experience, the oral stories also feature some personal attachment to the events that took place a century ago. An indirect presence of this period is felt in the frequent mentions of grandmother Dārte, as the whole conversation is reverted to the time of her life. Using the indirect discourse as a method of narrative formation, as if not telling the story itself, but recalling what was told and how, a seemingly unpretentious impression is created that Viktoria herself - the narrator - is just mediating between the narration situation of the past and the present one, substituting the real narrator, so as to convey his message to the audience of the present.

Also Bronns Štanins, a man from Timofeyevka, who had visited Latvia several times, told the story of emigration and the foundation of the village:

- Don't you know from where the ancestors came here?

- From Latvia.

- From Latvia. But which exact place?

- Who could say that! They were already here a long time ago. I cannot remember anything. My grandmother Māra, the mother of my mother. She had come from Latvia. But who knows from which exact place. Were 
there any relatives left behind? I was told there was a brother and two more sisters. In Latvia. And my mother also told me how... How should I tell you that? By the Jews. Say, grazing pigs in Latvia.

- So, and how did they get here?

- And then how did they get here? One needs land. Children were born to them. Here, there. Well, and the grandparents: "Let's go to Siberia!" Came to Siberia, here, by train. In the old days there was some train. A very slowly moving train, bit by bit. Came to Barabinsk. And that was it. Get off. On the land. But, they say, there was no forest back then. They made dugouts. There was no forest. Only later. Some years later the forest appeared. Started growing. They were in the dugouts. And somewhere in Urman, the northern district, there was forest. From there they brought timber. By horse and cart... And when the timber was processed, for a house or whatever. They floated it down the river.

The story of Bron,s Štaṇins covers all the most important details of the process in a brief form: the problem (one needs land), its cause (children were born), the solution (let's go to Siberia!) and the action (came to Siberia). After that the events of the story are localised in Siberia, reflecting arrangements of the space. This conversational episode on the emigration topic reveals in a stylistic bipartition at which point the personal memories of the life of Grandmother Māra in Latvia change into a narrative of generalised experience, with the question asked by the listener and then repeated by the informant himself (And then how did they get here?), marking the border between the two types of narrative. Although judging by the form, the second part of the narrative reflects the collectivised experience, the informant introduces in it personal nuances, twice referring to the statements of his grandparents. The use of direct speech creates the impression of presence at the communicative event of the past, at which Brons has not been personally present and which took place in Latvia, and at the same time adds vitality to the narrative. The informant pictures his grandparents as taking the decision to emigrate, and then illustrates it in a simplified manner, speaking in the voice of his grandparents (Let's go to Siberia!). Even if this insertion of direct speech is not a quote or a reference to a particular communicative event in the past, involving the grandparents, but instead is constructed at the present moment of communication (Tannen 2007: 102-132), with the informant successfully using customary narrative techniques, the experience of the grandparents in the life of the informant and all the references to their stories and actions in the narrative create and enliven these quoted persons in the stories, whose images in other cases have dissolved in the generalised narrative of the collectivised recollections. 
In a conversation with the seventy-year-old informant Gel,a Niminska, the emigration of her grandparents and foundation of the village were touched upon both in 2004 and 2006.

- But the grandmother, what did she sing, what did she tell?

- My grandmother may have also come here, come here a long time ago from Latvia, where she lived. I forget... But she told me a story or two, that there, when they lived in Latvia, there was no... was very little land. Let's say, there was a father and a mother, and they had, say, three or four sons. And when they get married, one has to give them some part of their land. And so they learned that here much land was available, and many came here. When they came here long ago, there was no village here, nothing. They say the Tatars, they lived on that hill. So it was called the Tatar hill. - Where?

- Just here, behind the village. And later, when they came here, they say, all the Tatars ran away, thought that who knows what has arrived... But now here in the hamlet there are none of those old people left. But my mother, I do not know whether she was born here or not. Never talked about that. Was she brought here from there? No, I cannot say that! Never occurred to me. So they said that the grandma and grandpa came here from there. And took some children with them. But my mother, I do not know whether she was born here or brought here. Can't be, I believe, that she was brought.

The initial fragment of this conversation shows how the informant tries to recall the communicative event, in which her grandmother told about the fact of emigration. It is worthy of note that she has recollections of the fact that such an event (or even several) has taken place (she told a story or two), while the basic events of emigration are characterised by her in the same manner of narration - devoid of any personality - the illustratively informative character of which she emphasises by calling a story an example (Let's say, there was a father and a mother, and they had, say, three or four sons). Personal nuances related to emigration can be traced at the very end of that excerpt, in which the informant, continuing the dialogue with herself, tries to evaluate her mother's connection with the emigration and refers to the stories told to her regarding her grandparents coming to the place, and bringing some children with them. In 2006, also asked about the possible origin of her ancestors, the informant repeatedly indicated lack of communication, which was already somewhat referred to in the conversation in 2004 . 
- Where could your ancestors have come from? Anyone never said anything? - I did not talk about it, no, and then we were just little kids. From where, from what place did these ancestors of ours come here? [...] Our grandmother and grandfather came here.

- But they never told you how they came?

- Not even a single mention, how they travelled, how they got here. [...] Who could have known that such a conversation is to be expected? They only said that they came here because of the land. When they found out that there was much land here. But there was no land here. If you have a family, and many children, there has to be land for all of them... When he gets married, the land has to be divided. And mostly because of that land they came. There were many of them here. There was a village Lyubamirovka, across the river. Before that they went there. But now there is no-one there either. [...] Not a living soul there. For many years crops are sown and hay is made on the land of that village. But this Timofeyevka? It came later, after Lyubomirovka. I also don't know which village came first. Maybe both at the same time. Maybe Timofeyevka, maybe... There were Ukrainians and Russians. But here there were more Latvians. There were no Russians in Timofeyevka in the olden days. Only Latvians lived here. But there are still Russians, Tatars, and many others.

Gela N̦iminska is one of the most knowledgeable psalm (Officium defunctorum) singers and preservers of the spirit of the Latgalian Catholicism in the village. There have been several individual interviews with this informant; she has taken part in the collective psalm singing documented both in 2004 and 2006. She tells willingly about the religious rituals and the context of their performance, celebration of festivities and handicrafts. The past and Timofeyevka's golden age, i.e., the time when the first generation of inhabitants lived there, is of great importance in the stories told by Gela Niminska. The characteristics of this period also reflect the basic values of her life - belief, family and work (as a union of knowingness ${ }^{9}$ and diligence). The events of the ancestors' emigration and foundation of the village do not affect her life directly, and as an event of indirect importance for the personal life of the informant, are reflected in the narrative in the form of collectivised experience.

Similarly to Savenko's stories, Niminska too, in both of the conversation fragments refers to the lack of communication, which is also frequently mentioned in conversations with the other informants. The discourse of communication that never happened is significant for the analysis of this topic. ${ }^{10}$ Niminska indicates the possibility of communication, had she known that "this kind of conversation will ever take place". The reason given for this lack of communication is the age difference of the generations: they were rather old (Savenko), we were still 
little kids then (Niminska), and the lack of personal interest in the events: we didn't show much interest (Savenko), never even occurred to me (Niminska). In a conversation about the founder of Timofeyevka, Timofejs Marnauza, Viktoria Ruduša plays the episode of the communication that never took place, asking her grandmother Dārte a question and, instead of an answer, providing a statement that the first generation of emigrants would have known that answer:

See, whatever kept me from asking mother Dārte long ago? - "Mum, who was the first to come to Timofeyevka?" - She did know that! These people who had come from Latvia themselves, they knew it!

The informants now are of the age as were their grandparents when it was about the last time to ask the latter questions about their lives. The time of youth of this generation, when the communication of a grown-up person with one's grandparents usually is the most active, happened to fall in a period when, due to social and political situation it was not desirable to emphasise one's origins. Besides, the importance of emigration in the life of Latgalian emigrants in Timofeyevka, and especially that of their descendants, was overshadowed by the tragic events of the late 1930s, the Second World War and the hardships of the post-war years, which not only altered the administrative and economic order established in the village, but also the whole life of the community, dramatically changing the population and the gender proportion. ${ }^{11}$ Viewing it from the perspective of the current older generation, one can understand the dominance of stories of these changes, the war and the post-war years, while the ancient events that have been witnessed by none of the now living have become seemingly insignificant in the context of the informants' own lives. The arrival of their grandmothers and grandfathers in Siberia and the foundation of the village are events that occupy a stable place in the collective memory of the village, while it is only of secondary importance for the lives of the narrators themselves.

The realisation of the communication that could have been raises regret in the narrators. Some of the informants are aware of their special status as representatives of the older generation in the preservation of the village's collective memory and the linguistic and religious identity (closely related to that), as well as their transmission to both the future generations and the researchers from the outside. ${ }^{12}$ Still, the discourse of the missing communication also reveals the critical attitude of the narrators towards their knowledge and that of the previous generations. For example, Viktoria Ruduša in her contrasting depiction of generations expresses her feeling of inferiority and, along with it, the loss of knowledge and skills not transmitted to the further generations (or not preserved): 
The people who lived in the olden days, our grandmothers... They knew everything! But what do we know? A story or two of our parents. What we have heard. And that is it. Nothing is left anymore.

The small episodes of memories that tell about the people who came to this distant place and the conversations with them that are preserved by the current inhabitants of Timofeyevka relate to the nostalgia of the ages as expressed in the contrasts of the past and the present and reflected in a dialogical unity of loss and idealisation. The generation of the first settlers symbolises the lost knowingness of the community, which cannot be restored anymore. The motif of idealisation of this generation appears in a close relationship with the time of their lives; namely, the emotional landscape of the age of the village's origins can be found in the stories about the people of this period. Bron, Štanins's grandmother Māra and Viktoria Ruduša's grandmother Dārte, as well as the reflection of the whole first Latgalian generation of Timofeyevka in oral narratives embodies the values that are connected with the period of the village's origins not only for Brons and Viktoria, but also their other contemporaries. And of these values the most important are religiousness, knowingness and diligence.

Narratives about the grandparents project an idealised idyllic landscape of the first years of Timofeyevka, when the flow of mental and economic life, festivities and everyday events was harmonious. Mentioning of grandparents and their stories in the thematic and emotional contexts allows to perceive this generation as a knowing, active and skilful one, while this period is perceived as one of the best in the history of Timofeyevka ${ }^{13}$, when the village's population was larger, when people knew what and how to do, and when social and religious life was much more active. The grandparents of the inhabitants of Timofeyevka are no runaways who abandoned their culture in Latgale. They are the newcomers - the bringers of culture, the cultivators of the empty space and Latgalianness, and for the future generations a direct link to Latvia and the values brought to Siberia from there. ${ }^{14}$

\section{CONCLUSION}

At the turn of the 20th century, the printed media was among the few forms of mass media regularly informing the public about the news; therefore the role of the printed media in the emigration processes that took place at the time was substantial. The Latgalian emigration was reflected by two opposing propaganda campaigns: one was proposing emigration, the other was opposing it. As the 
newspapers were managed by Latgalian intelligentsia and representatives of the national awakening movement, which was concerned about the nation's mental and material development, the newspapers were mostly opposed to emigration, while the news about emigration from its proponents also reached the potential emigrants via other ways, including those of personal communication. As a result of these campaigns, the newspapers created a contradictory image of the emigrants and their desired Siberia. Siberia became the Latgalians' "promised land", while the emigrant was pictured as a lucky person, awarded with an excellent and realistic opportunity to change one's life for the better, described in colourful epithets, metaphors and similes. The mythicised images of Siberia and the emigrants are used on either front, but while the proponents of emigration construct them, the opponents intercept these constructs, hyperbolise and then deconstruct them, using them as a contrast to the actual Siberia (harsh and demanding hard work) and the emigrant (an uneducated peasant, naive and incapable of rational decision-making). Over the course of time, the images of the emigrants and their desired Siberia have been turned into clichés, representing the obsessed emigrants and their imagined lands of happiness, which are also used in modern discussions concerned with Latvian emigration.

One of the Latgalian colonies - the current village of Timofeyevka - is inhabited by the grandchildren of the first Latgalian colonists. The oral narratives recorded during field research carried out in 2004 and 2006 show that their memories of their grandparents, their long journey and settling in are rather scarce. They contain few personal details and their characteristic form is generalised experience. The very descendants of the emigrants quite frequently indicate that they were not told about the emigration and they were too young to ask about how the Latgalians came to Siberia. In the stories about Latgalian emigrants - the grandparents of the inhabitants of today's Timofeyevka - an idyllic scene of the first years of Timofeyevka is drawn, with balanced and well-developed economic and mental life. The image of the emigrant is just the opposite to the simple-minded Latgalian who is lost to his nation because of the departure from the native land; that is the notion cultivated in the discussions of the turn of the 20th century by the opponents of emigration. The inhabitants of today's Timofeyevka picture the colonists as a knowledgeable, active and skilful generation, capable of transporting these Latgalian qualities and develop them in an empty space, thus creating a reference to the image of the decisive, practical and successful emigrant created a century ago by the proponents of the migration. 


\section{NOTES}

1 Latgale is the eastern part of Latvia, approximately one-fourth of the total territory of today's Latvia. Latgalians, unlike the rest of Latvians (who are mainly Lutherans) traditionally belong to the Roman Catholic faith. Historically Latgale was separated from the rest of Latvia (at that time a Baltic province), as it was part of Vitebsk province. Therefore life in Latgale followed different rules and its administration applied different principles. Because of these as well as other reasons many of the economic, legislative, social and cultural processes in Latgale took turns completely different from those taking place in other territories inhabited by Latvians (Zelče 2009: 51). Since the 18th century, Latgalians have had a separate literary language of their own, which has been used in books and newspapers, and from time to time has also been taught as a separate subject at school. The Latgalian literary language saw its heyday at the beginning of the 20th century, when many newspapers and books were published in it, and respective grammar books and dictionaries were compiled. From 1918, when the Latvian national state was founded, and until 1934, when Kārlis Ulmanis established his authoritarian regime, there were special classes of the Latgalian literary language at the schools of Latgale.

2 The migration processes within the Russian Empire were strongly influenced by the social and political change at the end of the 19th century: first, it was the agrarian reform initiated by the Minister of the Interior, Piotr Stolypin, that promoted the division of villages into separate farmhouses (PSZ 1909: 970), which meant that land availability (which was scarce already) decreased still further; second, developments in the transport system at the end of the 19th century, in particular the construction of the Trans-Siberian railway, which contributed to making the migration of peasants from the European part of Russia to Siberia a mass movement, with Siberia becoming one of the world's most popular migration destinations by the numbers of migrants (Moon 2002; McKeown 2004: 156-157; Manning 2005: 147; Leasure \& Lewis 1968: 376).

3 According to the all-Russian census of 1897, there were slightly more than 500,000 inhabitants in Latgale. Also those who returned from Siberia after some not so long period of time may have been counted as emigrants. Initially every third emigrant re-emigrated; later on the number of those who changed their minds reduced (Kaufman 1905: 248; see also Kiikuts 2011: 39, 42; Kursīte 2011: 18-19). A more exact count of the Latgalian emigrants requires specific additional study.

${ }^{4}$ Old-Russian unit of land area; 1 dessiatine equals roughly 1 ha.

5 The Latvian phrase "Savs kaktiņš, savs stūrītis zemes" is an idiomatic metaphor, originating from the 19th century Latvian literature, which continues to exist in the Latvian language as an expression of the historically rooted striving for some private property.

6 The migration required available means that were frequently gathered by selling all of one's property, including cattle and tools. At the same time it meant severing ties with the homeland. Well-off peasants moved to Siberia rather rarely; more frequently those were families of craftsmen that owned no land, families that earned their subsistence by seasonal work, as well as the ones with a great number of male descendants. Historian Toms Kikuts, using the material on Latgalian emigration available in the archives, projects a typical emigrant's family: “[...] on average, there were 6.4 persons 
and the head of such a family (practically in all cases it was a male) was on average 38 years old, [...] larger families usually did not have a great number of children, but it was a number of single and married siblings emigrating together with their parents" (Kikuts 2011: 37-38).

7 An expression about the emigrants to Siberia by the Latgalian intellectual of the turn of the 20th century, Francis Trasuns (Drywa 1909: 1).

8 A similar observation was made by social anthropologist Roberts Kīlis, while carrying out his fieldwork in the Latvian colony Bobrovka: "[...] in the narrative it is difficult to ascertain what one would call a life story - the life line leading through several stories and including in it a sequence of life experiences. [...] The villagers avoided portraying themselves in the centre of events or processes" (Kīlis 2002).

9 This notion in the context of the article is used to denote a set of diverse knowledge of practical, religious, magical and aesthetic realms.

10 In a narrative, such remarks can be characterised as meta-narrative comments (Babcock 1977: 67), which explains why the narrative is as it is.

11 "The Soviet rule, collectivisation of the countryside, repressions against the peasants and the intelligentsia led to the loss of the mental dimension (language, religion, education), along with heavy physical loss, especially during the repressions of 1937-1938, when the majority of males in Timofeyevka were arrested and executed, but also during the Second World War. Intimidated by the repressions, weakened by the war and the postwar famine, the colonists gradually lost their Latgalian identity" (Kursite 2011: 24; see also Brolišs 1998: 12; Kolotkin 2012: 54-55).

${ }^{12}$ Here a special note must be made of the self-respect of the first Latgalian emigrants in the preservation of their language, as attested by numerous informants, indicating the strictness in the attitude towards the language used in communication with children.

${ }^{13}$ In the stories told by the villagers it can be felt that there was another golden age around the $1960 \mathrm{~s}-70 \mathrm{~s}$, which in the narratives is similarly contrasted to the current situation. It is the time when certain social wellbeing and stability was attained, and there was active social life in the village, and, simultaneously, it was the time of youth of the generation which is now the oldest in the village. The stories about the past recreate a world for the representatives of the older generation, in which they were more potent than they are now; in this narrative world, the narrator has considerably greater control over this world of events than he/she has ever had, even while actually living in it (Young 1987: 200).

${ }^{14}$ One of such symbols asserting the identity and religious cultural values is, e.g., the Catholic song and prayer books which were brought from Latvia by the emigrants, and which several of the villagers have managed to preserve until today. It was customary to bury the book along with its owner, but the people of Timofeyevka have testified that, contrary to the wish of a grandparent or parent, the books could also have been preserved. 


\section{MANUSCRIPT SOURCES}

Fieldwork materials from the years 2004 and 2006 in possession of the author.

\section{REFERENCES}

Apeḷs, Meikuls 1970. Latgalīšu školas un cyti kulturas posōkumi Sibirijā. [Latgalian Schools and Other Cultural Events in Siberia.] Acta Latgalica, Vol. 3, pp. 153-183.

Auseklis 1906 = Latwiszu kolonisti nu Witebskas gubernas. [Latvian Settlers from Vitebsk Gubernia.] Newspaper Auseklis, No. 1, March 17, p. 3.

Babcock, Barbara A. 1977. The Story in the Story: Metanarration in Folk Narrative. In: R. Bauman (ed.) Verbal Art as Performance. Rowley, MA: Newbury House Publishers, pp. 61-79.

Baines, Dudley E. 1995. Emigration from Europe 1815-1930. Cambridge: Cambridge University Press.

Berdoulay, Vincent 1989. Place, Meaning and Discourse in French Language Geography. In: J. A. Agnew \& J. S. Duncan (eds.) The Power of Place: Bringing Together Geographical and Sociological Imaginations. Boston: Unwin Hyman, pp. 124-139.

Brolišs, Jāzeps 1998. Latgales latviešu izcel̦ošana uz Sibīriju. [The Emigration of Latvians from Latgale to Siberia.] LZA Vēstis, Vol. 52, No. 4/6, pp. 11-15.

Bula, Dace 2000. Dziedātājtauta: Folklora un nacionālā ideologiija. [The Singing Nation: Folklore and National Ideology.] Rīga: Zinātne.

Butler, Gary R. 1990. Saying Isn't Believing: Conversation, Narrative and the Discourse of Belief in a French Newfoundland Community. Newfoundland: Institute of Social and Economic Research.

Bycans Odums 1907. Par Sibiriju. [About Siberia.] Newspaper Auseklis, No. 35, September 20, pp. 1-2. Available at http://data.lnb.lv/nba01/Auseklis/1907/Auseklis1907-35. pdf, last accessed on July 1, 2014.

Dickinson, Hilary \& Erben, Michael 2006. Nostalgia and Autobiography: The Past in the Present. Auto/Biography, Vol. 14, pp. 223-224. Available at http://autobiography. stanford.clockss.org/aub_2006_14_3/10.1191_0967550706ab048oa.pdf, last accessed on May 12, 2014.

Drywa 1909 = Nu kurines gaidama globsona. [From Where Can We Await Rescue.] Newspaper Drywa, No. 14, March 25, p. 1. Available at http://data.lnb.lv/nba01/ Drywa/1909/Drywa1909-014.pdf, last accessed on July 1, 2014.

Hamerow, Theodore S. 1983. The Birth of a New Europe: State and Society in the Nineteenth Century. Chapel Hill: The University of North Carolina Press.

Handler, Richard 1988. Nationalism and the Politics of Culture in Quebec. Madison: The University of Wisconsin Press.

Hatton, Timothy J. \& Williamson, Jeffrey G. 1994. What Drove the Mass Migrations from Europe in the Late Nineteenth Century? Population and Development Review, Vol. 20, No. 3, pp. 533-559.

Hoerder, Dirk \& Rössler, Horst (eds.) 1993. Distant Magnets: Expectations and Realities in the Immigrant Experience, 1840-1930. New York: Holmes \& Meier. 
Jürgenson, Aivar 2002. The Wild and Homely Siberia: How Siberian Estonians Perceive Their Natural Environment. Folklore: Electronic Journal of Folklore, Vol. 21, pp. 52-76. doi:10.7592/FEJF2002.21.siberia.

Kaufman 1905 = Kaufman, Aleksandr A. Pereselenie $i$ kolonizatsiia. [Resettlement and Colonisation.] Sankt-Peterburg, 1905. Available at http://shpl.dlibrary.org/ru/ nodes/3900\#page/1/mode/flip-book/zoom/3, last accessed on May 13, 2014.

Kikuts, Toms 2011. Dokumentāro avotu liecības par Latgales zemnieku izceḷošanu uz Sibīiju 19. gadsimta 90. gados un 20. gadsimta sākumā. [Evidence from Documentary Sources Regarding the Migration of Latgalian Peasants to Siberia in the 1890s and Early 20th Century.] In: A. Lielbārdis (ed.) Latvieši latviešu acīm: Sibīija. Timofejevka. [Latvians about Latvians: Siberia. Timofeyevka.] Riga: LU LFMI, pp. 29-48.

Kīlis, Roberts 2002. Nodomu valoda: atbildība un vainošana Babraukas ciema iemītnieku stāstos. [The Intent Language: Responsibility and Blame in the Stories of Inhabitants of Babrauska Village.] In: A. Lūse (ed.) Cilvēeks. Dzīve. Stāstījums. Rīga: Latvijas antropologu biedrība \& LU Literatūras, folkloras un mākslas institūts, pp. 81-94.

Kolotkin 2012 = Kolotkin, Mikhail. Latgal'skie poselentsy v Sibiri. [Latgalian Colonists in Siberia.] Achinsk \& Sankt-Peterburg: Filologicheskii fakul'tet SPbGU. Available at http://www.latgalec-ru.narod.ru/publikacii/Kolotkin.pdf, last accessed on May 13, 2014.

Kursīte, Janīna 2011. Latvieši Sibīrijā: ieskats izcel̦ošanas problemātikā. [Latvians in Siberia: Issues of Emigration.] In: A. Lielbārdis (ed.) Latvieši latviešu acīm: Sibīija. Timofejevka. [Latvians about Latvians: Siberia. Timofeyevka.] Riga: LU LFMI, pp. 17-28.

Latviešu Avīzes 1890. Kamdēl latvieši aiziet uz citām zemēm? [Why Latvians Emigrate to Other Countries?] Newspaper Latviešu Avīzes, No. 3, January 17, pp. 1-2. Available at http://www.periodika.lv/periodika2-viewer/view/index-dev. html\#panel:pp| issue:/p_001_laav1890n03 | page:1| issueType:P, last accessed on May 13, 2014.

Leasure, William J. \& Lewis, Robert A. 1968. Internal Migration in Russia in the Late Nineteenth Century. Slavic Review, Vol. 27, No. 3, pp. 375-394. doi: $10.2307 / 2493340$.

Lejdumniks J. 1907. Tur labi, kur myusu nav. [It Is Good Where We Are Not.] Newspaper Auseklis, No. 19, May 17, p. 3. Available at http://data.lnb.lv/nba01/Auseklis/1907/ Auseklis1907-19.pdf, last accessed on May 13, 2014.

L-niks 1907. Gòjejim uz Sibiriju. [For Siberian Emigrants.] Newspaper Auseklis, No. 28, July 26, p. 2. Available at http://www.theeuropeanlibrary.org/tel4/newspapers/ issue/3000059903610?page=2, last accessed on May 13, 2014.

Manning, Patrick 2005. Migration in World History. New York: Routledge.

McKeown, Adam 2004. Global Migration, 1846-1940. Journal of World History, Vol. 15, No. 2, pp. 155-189. Available at http://www.jstor.org/discover/10.2307/20068611?u $\mathrm{id}=3737920 \&$ uid $=2129 \&$ uid $=2134 \&$ uid $=2 \&$ uid $=70 \&$ uid $=4 \& \operatorname{sid}=21104155571963$, last accessed on May 13, 2014. 
Mežs, Ilmārs 2011. Statistiskās ziņas par Sibīijas latgaliešiem: Timofejevkas etnodemogrāfiskais apskats. [Statistical Information about Latgalians in Siberia: An Ethno-Demographic Survey of Timofeyevka.] In: A. Lielbārdis (ed.) Latvieši latviešu acīm: Sibīrija. Timofejevka. [Latvians about Latvians: Siberia. Timofeyevka.] Riga: LU LFMI, pp. 67-82.

Moon, David 2002. Peasant Migration, the Abolition of Serfdom, and the Internal Passport System in the Russian Empire c. 1800-1914. In: D. Eltis (ed.) Coerced and Free Migration: Global Perspectives. Stanford, CA: Stanford University Press, pp. 324-357.

PSZ 1909 = Polnoe sobranie zakonov Rossiiskoi Imperii. [Complete Collection of Laws of the Russian Empire.] Sobranie Tret'e. T. XXVI. Sankt-Peterburg.

Ripa 1906. Par izišonu uz Sibiriju. [About Emigration to Siberia.] Newspaper Auseklis, No. 34, December 6, pp. 2-3. Available at http://data.lnb.lv/nba01/Auseklis/1906/ Auseklis1906-34.pdf, last accessed on May 13, 2014.

Ripa 1907. Pòrsacelšona uz Sibiriju uz dzejvi. [Moving to Siberia.] Newspaper Auseklis, No. 14, April 5, p. 3. Available at http://data.lnb.lv/nba01/Auseklis/1907/ Auseklis1907-14.pdf, last accessed on May 13, 2014.

Rosoli, Gianfausto 1993. From "Promised Land" to "Bitter Land": Italian Migrants and the Transformation of a Myth. In: D. Hoerder \& H. Rössler (eds.) Distant Magnets: Expectations and Realities in the Immigrant Experience, 1840-1930. New York: Holmes \& Meier, pp. 222-240.

Sākla 1906. Sibirija ir daudzi najznimtas wel zemes. [There Is Much Free Land in Siberia.] Newspaper Sākla, No. 8, April 15, p. 3. Available at http://data.lnb.lv/ nba01/Sakla/1906/Sakla1906-8.pdf, last accessed on May 13, 2014.

Sk. 1909. Tim, kas uz Sibiri paušas. [For Those Who Plan to Go to Siberia.] Newspaper Drywa, No. 15, April 10, p. 2. Available at http://data.lnb.lv/nba01/Drywa/1909/ Drywa1909-015.pdf, last accessed on June 26, 2014.

Sk. 1910. Uz Sibiri. [To Siberia.] Newspaper Drywa, No. 45, May 13, p. 3. Available at http://data.lnb.lv/nba01/Drywa/1910/Drywa1910-045.pdf, last accessed on May 13, 2014.

Skrinda, K. 1909a. Kur dzeivoj latviši, kas aizbrauce uz Sibiri. [Where Do Those Latvians Live Who Emigrated to Siberia.] Newspaper Drywa, No. 27, October 14, p. 2. Available at http://data.lnb.lv/nba01/Drywa/1909/Drywa1909-027.pdf, last accessed on July 1, 2014.

Skrinda, K. 1909b. Weiskupa celš pa Sibiri. [Bishop's Path through Siberia.] Newspaper Drywa, No. 29, November 10, p. 4. Available at http://www.theeuropeanlibrary. org/tel4/newspapers/issue/3000059908674?hp=1\&page=4\&query=drywa+1909\& offset $=20 \& y=1748.0 \& x=1122.0$, last accessed on May 13, 2014.

Skrinda, K. 1909c. Weiskupa celš pa Sibiri. [Bishop's Path through Siberia.] Newspaper Drywa, No. 30, November 24, p. 3. Available at http://data.lnb.lv/nba01/ Drywa/1909/Drywa1909-030.pdf, last accessed on May 13, 2014.

Skrinda, K. 1909d. Weiskupa celš pa Sibiri. [Bishop's Path through Siberia.] Newspaper Drywa, No. 31, December 7, pp. 3-4. Available at http://data.lnb.lv/nba01/ Drywa/1909/Drywa1909-031.pdf, last accessed on May 13, 2014. 
Skrinda, K. 1910a. Weiskupa celš pa Sibiri. [Bishop's Path through Siberia.] Newspaper Drywa, No. 36, February 9, pp. 3-4. Available at http://data.lnb.lv/nba01/ Drywa/1910/Drywa1910-036.pdf, last accessed on May 13, 2014.

Skrinda, K. 1910b. Weiskupa celš pa Sibiri. [Bishop's Path through Siberia.] Newspaper Drywa, No. 37, February 19, pp. 3-4. Available at http://data.lnb.lv/nba01/ Drywa/1910/Drywa1910-037.pdf, last accessed on May 13, 2014.

Svenne, Oto 1923. Vecā un jaunā Latgale un vin,as īpatnības. [The Old and New Latgale and Their Pecularities.] Rīga: A. Ozoliṇa spiestuve. Available at http://gramatas.lndb.lv/ periodika2-viewer/view/index-dev.html\#issue:/g_001_0309048790|issueType:B, last accessed on July 1, 2014.

Tannen, Deborah 2007. Talking Voices: Repetition, Dialogue, and Imagery in Conversational Discourse. New York: Cambridge University Press.

Trasuns, F. 1908. Kù roksta b-kungs F. Trasuns par izišonu uz Sibiriju? [What Does Priest F. Trasuns Write about Emigration to Siberia?] Newspaper Drywa, No. 3, July 14, p. 3. Available at http://data.lnb.lv/nba01/Drywa/1908/Drywa1908-003. pdf, last accessed on May 13, 2014.

Tučs, M. 1909. Latwiši Sibirê. [Latvians in Siberia.] Newspaper Drywa, No. 19, June 12, p. 3. Available at http://data.lnb.lv/nba01/Drywa/1909/Drywa1909-019.pdf, last accessed on May 13, 2014.

Wolf-Knuts, Ulrika 2003. Contrasts as a Narrative Technique in Emigrant Accounts. Folklore, Vol. 114, No. 1, pp. 91-105.

Young, Katharine Galloway 1987. Taleworlds and Storyrealms: The Phenomenology of Narrative. Dordrecht \& Boston \& Lancaster: Martinus Nijhoff Publishers.

Zelče, Vita 1999. Pirmā latviešu emigrācijas kampaņa. [The First Latvian Emigration Campaign.] Latvijas Arhīvi, Vol. 3, pp. 76-88. Available at http://www.arhivi. lv/sitedata/ZURNALS/zurnalu_raksti/76-88-VESTURE-Zelce.pdf, last accessed on May 13, 2014.

Zelče, Vita 2009. Latviešu avīžniecība: Laikraksti savā laikmetā un sabiedrībā 18221865. [Latvian Newspapers in the Context of Their Time.] Rīga: Zinātne. 


\title{
IN THE BEGINNING, THIS WAS AN EMPTY PLACE... PLACE-RELATED NARRATIVES IN TIMOFEYEVKA, SIBERIA
}

\author{
Sandis Laime
}

\begin{abstract}
The current article focuses on the place-related narratives collected in Timofeyevka village (Novosibirsk Oblast, Russian Federation), which was established in 1895 by emigrants from eastern Latvia (Latgale). The aim of the article is to discuss the reasons for the creation and functions of these narratives, at the same time attempting to grasp the significance of referring to the specific place. The material has been subdivided and characterised in detail in four groups according to its genre affiliation: personal and collective experience stories, memorates and legends. The article is based on material collected in Timofeyevka during the fieldwork of 2004 and 2006.
\end{abstract}

Keywords: emigrants, ethnocentric legends, Latgalians, memorates, personal and collective experience stories, place-related narratives, Siberia

One of the most characteristic features of place-related narratives is that they are made functional only in close connection to the specific elements of geographical and cultural landscape. An interesting aspect of the study into placerelated narratives is the creation of this layer of folklore and its functioning within emigrant communities, which, having settled in a foreign territory, have created their own layer of place-related narratives and toponyms in their new place of life, thus not only adapting to the new environment and creating spatial landmarks, but also accumulating individual and collective experience. In this respect, Siberian villages established at the turn of the 20th century by deported convicts and emigrants from the European part of the Russian Empire constitute a remarkable and valuable field of research.

At the end of the 19th and beginning of the 20th centuries, tens of thousands of people from all regions of Latvia moved to Siberia. Several of the settlements that were established in Siberia by Latvians have survived until today. One of them is Timofeyevka village on the left bank of the River Tartas in Vengerovo district of Novosibirsk Oblast (Fig. 1), which in 2004 had 170 inhabitants, of whom 66 (or $39 \%$ ) were Latgalians ${ }^{1}$ by their ethnic origin, and $28 \%$ of them - 


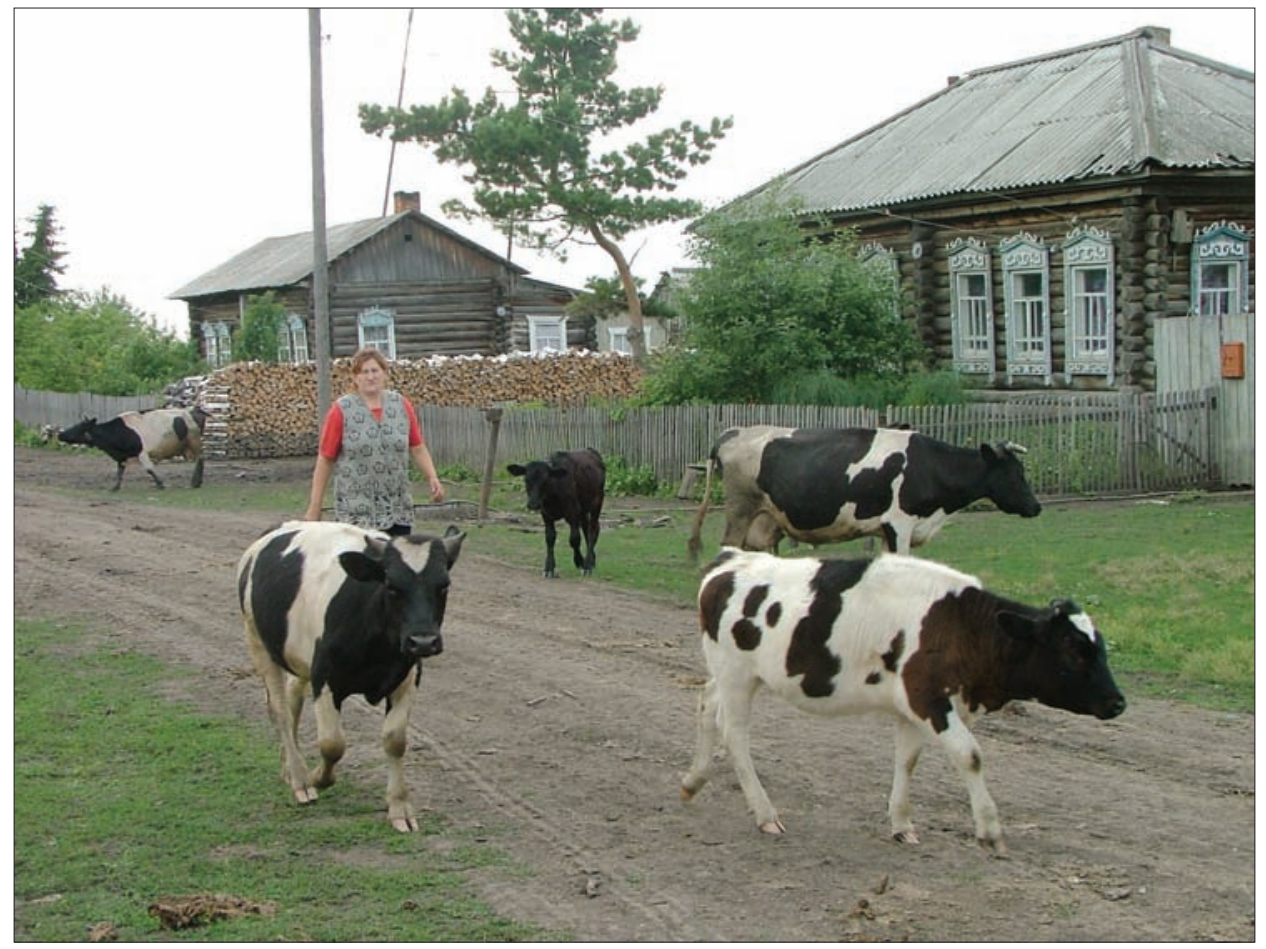

Figure 1. The main street in Timofeyevka village. Photograph by Sandis Laime 2006.

mainly old and middle-aged people - had excellent or moderately good knowledge of Latgalian (Mežs 2011: 72-74).

Timofeyevka was established around 1895 by Latgalians who had emigrated to Siberia (Melnalksnis 1938: 308). Judging by the fragmented information provided by the villagers and found in archives, the name of Timofeyevka might have been derived from the name of its founder Timofejs Marnauza (Kursīte 2011: 20-21). ${ }^{2}$ The area of the Timofeyevka settlement was approximately $40 \mathrm{~km}^{2}$, which was subdivided into 114 separate land lots. The most distant land lots allocated to Timofeyevka inhabitants were about 10 kilometres away from the village. Timofeyevka was the settlement's administrative and religious centre: prior to collectivisation, the centre of the village featured not only Latgalian farmsteads, but also a dairy, a school and a Catholic church (Melnalksnis 1938: 308). By registering for a particular section of land, the head of the family acquired rights to occupy a land lot, the area of which depended on the number of male members in the family. Each male member received 10-15 dessiatines (approximately 11-16.5 hectares), which still remained in state ownership, 
but was transferred into the use of the farmer and its successors forevermore (ibid.: 329). The land lot allocated to each family was unofficially named after the surname of the farmer, thus the area of the village was gradually covered with land lots named after the inhabitants. Part of these place names are still used today. They have been adopted not only by Latgalians who have moved to Timofeyevka from other villages, but also by members of other ethnic groups, who have settled in the village since the middle of the 20 th century.

The idea of collecting place-related narratives emerged during fieldwork in Timofeyevka in 2004, when the first interviews revealed that the villagers used place names that seemed to have been coined by themselves. Later on, some places emerged (Tonkas griva, Tataru kolns, etc.), about which the villagers produced more or less detailed narratives. This article is based mainly on the material acquired during interviews conducted by the author; the material was systematically collected during the 2004 and 2006 fieldwork $^{3}$. The place name and folklore material in the form of a dictionary was summarised in a separate publication (Laime 2011). Collections of a smaller volume of place-related folklore and toponyms were acquired also in other Latvian villages in Siberia (see Blinkena \& Stafecka 1995: 112-113; Laime 2007: 152-153; Rozenbergs 1995: 133).

The aim of the analysis of the comparatively few place-related narratives written down in Timofeyevka is to understand the reasons for creating and telling these stories, at the same time attempting to grasp the significance of referring to the specific place in each case. The material collected in field research has been classified and analysed according to its genre affiliation. Depending on the content and form of the narratives, they have been subdivided and characterised in detail in four groups: personal and collective experience stories, memorates and legends.

Part of the places situated in the vicinity of Timofeyevka are sometimes mentioned in the informants' personal experience stories. Certain places in the vicinity of the village are linked to episodes of the personal experience of each villager, which are in turn linked to chronologically different stages of human life. The topicality of these stories in the repertoire of informants is determined by different factors: the uniqueness of the event, i.e., a tragic, comic or otherwise unusual situation that forms the core of the potential story; the significance of the event in the course of the informant's life; the subjective wish or unwillingness to tell the specific episode of experience to somebody else, etc. Narrations of this kind cannot be included in the indexes of legend types and they have variations neither in the aspect of time nor in the aspect of place (Garda-Rozenberga 2008: 140). Sandra Stahl argues that "the individual's perception of his experience will be variously affected by collective structures 
or concepts, but the story about the experience will remain sufficiently 'individual' because of the unique combination of collective and individual aspects represented by the individual personality" (Stahl 1977: 16-17). Thus also each place-related narrative that is based on personal experience is unique, as certain objective realia (the place) intertwine with subjective experience, creating a unique combination, which usually, however, becomes a part of historic, social and other contexts significant to the whole community.

The personal experience stories related to specific places constitute a part of the most dynamic repertoire of Timofeyevka place-related narratives. For example, interesting events may be told when discussing the events of the day in the evening, in the family circle or among friends, but afterwards these narrations may lose topicality and be forgotten, and only the most vivid events are conserved in the repertoire. Sandra Stahl notes that, in order to become a successful performance, "a personal narrative must make some statement about the topic in terms of traditional attitude" (ibid.: 24). In this case the link to specific places may lose significance, putting the event in the focus of attention. This situation can also be observed in relation to personal experience stories heard in Timofeyevka: the further in the past a particular episode of experience was set, the less frequently it was linked to a specific place. This may be caused by a number of reasons. First, the aspect of place is not crucial in relation to the event and traditional attitudes; therefore this detail is lost in the story as time goes by. Second, the place is not specified as the listener (interviewer) does not have good knowledge of the local landscape, hence it is not important from the point of view of the informant to specify the place. Third, the omission of place in the narration may be stimulated by changes in the landscape, etc.

The personal experience stories related to specific places are mainly in the repertoire of experiencers, and less often in the repertoire of the people closest to them. Other members of the community, although they might have heard the story, usually do not retell it further, as the aim of this genre is to share personal experience.

In my research, I have classified some of the narratives based on real events as collective experience stories. Although the specific events have been experienced by one or some members of the community, this experience might be important to the whole community for a number of reasons; therefore, by generalising the event, the experience becomes collective and, unlike personal experience, is told in a wider circle with the aim of putting into focus various ethical, social, religious or other norms accepted in the community. The informant does not have to be the experiencer or the eyewitness of the event; however, if the informant has personally experienced the event, it may, at the same time, be his or her personal experience story. As the accuracy of events 
contained in these stories is gradually lost and the participants of the event are typified, collective experience stories may become legends over a longer period of time. Specific places involved in such events may be given names related to the specific event.

The most vivid collective experience stories documented in Timofeyevka are related to the so-called Tonkas griva (Toņka's hillock). The story is based on an accident that took place in the vicinity of Timofeyevka in the years of the Second World War: on a field while threshing grain, the threshing machine pulled in a young girl called Tona (full name - Antonia), who died on the site; therefore the place of the accident was named Tonkas griva (Laime 2011: 180-181). This place name and the story associated with it is known not only to the contemporaries of the event, but also to those villagers who were born after this event, and also to people who have moved to Timofeyevka in the last decades. The event was described in detail only by two informants: Valentina Bule, who was the younger sister of Antonia, and Nina Kukule, who saw the crippled body of Antonia when it was brought to the village. In addition, the latter's uncle was an eyewitness to the event. These narrations also contain a short characterisation of Antonia's family and the circumstances of the accident, while in the stories by other informants, who do not have a direct connection to Antonia or the event, additional information is usually omitted and only the tragic fact of the accident is emphasised.

There are at least two reasons why this accident became a part of collective experience in Timofeyevka community and is still told nowadays, half a century after the actual event. First, remembering and retelling this event is an indirect illustration of workplace safety rules, and the consequences that may occur if they are ignored. Thus, when telling about the tragic death of Antonia, the community focuses on a stricter observance of workplace safety rules. Second, human death in accidents, just like suicide, murder, or any similar death before one's time, is traditionally regarded as unclean. This can be said especially about accidents, in which young unmarried people have died in an unnatural way. ${ }^{4}$ Fear of the people who have died an unclean death is based on the belief that the souls of the people who have died before their time stay on the earth, usually in the place of accident, and may harm the living. In this context, a remark included in the story by Viktoria Ruduša is significant: she said that the villagers had been so scared by the accident that even a long time after the event everyone saw the deceased Antonia in their dreams.

During fieldwork, no villager was met who would have been an eyewitness of the event and would retell it as his or her personal experience story, although it is certain that there were such people. The narrations of the eyewitnesses of the event have enabled this story to become a collective experience story, as the 
accident shocked not only Antonia's relatives, but also the whole community of Timofeyevka. Already now, one can observe the process of the specific additional event-related information disappearing from the narrations, preserving only the mere fact of the accident. Thus in the future, narratives about Tonkas griva may transform into a legend telling that in Tonkas griva a young and beautiful girl called Tona met her death (and therefore this place is bad, haunted by ghosts, one should not go there, or similar interpretations). There are hundreds of places in Latvia about which such limited-content legends are told. Their background information is long forgotten, only the name of the person who committed suicide, was murdered, or died in an accident, has survived. Over time, new personal experience stories and memorates about people's experiences and troubles at the bad place twine around such places and continue the oral tradition related to the specific place.

A second scenario is also possible for the development of the tale on Tonkas griva. With the gradual disappearance of the background information connected with the accident, the tale may simply fade away. It seems that this has happened to the tales about Magdas pürs (Magda's swamp) in the vicinity of Timofeyevka. In Latvia, if legends are told about a place and this place carries a name related to the narration, the place name is the last to disappear from oral tradition. Even if legends or tales about a specific place are not told anymore, its name can still be preserved, if people use it as a landmark in their communication. Today, the place name of Magdas pürs is still actively used by Timofeyevka villagers, as the swamp is situated near the village; however, during fieldwork, the author did not manage to ascertain a specific event from which the name of the swamp could have been derived. Only Veronika Pridane said that the swamp was called this way because of some Magda, who had wanted to hang herself there (Laime 2011: 177). If this really happened, such an event might have been preserved in the memory of the villagers for some time, especially taking into account the fact that in a Christian society suicide is considered to be a mortal sin. An attempted suicide would also be a sufficiently significant fact to name the specific place after the unfortunate woman. Other villagers linked Magdas pürs to a Magda who had lived a very long life, more than a hundred years; therefore the swamp is also called Babas pūrs ('Grandmother's swamp') (Laime 2011: 177). Considering all this, the Magda-related events might have taken place in the swamp soon after Timofeyevka had been established at the end of the 19th century or at the beginning of the 20 th century. This is indicated by the fact that the swamp-related event was already known to the mother of the oldest villager, Vera Kalugina (b. 1914), who had told Vera about it when she was still a child. It seems that the events that took place in the swamp more than one hundred years ago have now lost their topi- 
cality; therefore the majority of Timofeyevka villagers have only preserved the name of the swamp and not the narratives related to it. The information given by Tatiana Peščerska that the swamp was named after the surname Magda (Laime 2011: 177) indicates a more recent tradition that the creation of a place name is explained with the technique of building place names most frequently used in the vicinity of the village, i.e., it was derived from the surname of the person who farmed the specific land lot.

In memorates, unlike in personal and collective experience stories, events based on the personal experience of the informant or a person close to him or her are interpreted as supernatural. On the one hand, memorates are similar to personal experience stories, as they reveal an emotional experience of the informant or persons close to him or her. On the other hand, they are similar to belief legends, as the event is later directly or indirectly interpreted in accordance with the beliefs that exist in the community about supernatural beings and phenomena. Interpretation is directly influenced by the discussion of an event within the community, if a phenomenon that has been experienced in the state of numen (a supernatural being without clear manifestation) is identified according to the preconceptions of the community and enters the state of omen, acquiring the figure of a specific supernatural being (Honko 1989: 108). Indirectly, the interpretation can be introduced also by the experience author on the basis of the preconceptions existing in the community.

The majority of memorates heard in Timofeyevka are not linked to specific places near the village. Such, for example, is the supernatural experience of several villagers involving house spirits, as this layer of beliefs still functions in the village. The only two memorates about specific places of the vicinity of Timofeyevka are related to the village cemetery (Fig. 2). Graveyard as a place for the burial of the dead is a significant object in the inhabited space of any community that holds various norms in high regard. The significance of the graveyard in the landscape of Timofeyevka is expressed, for example, by the fact that the word kapi, or Latgalian kopi (graveyard), is contained in the names of the places closest to the graveyard, such as the near Kopu zaimka ${ }^{5}$ and the stream Kopu ryucs.

In the memorate told by Vera Kalugina, a situation is depicted in which a norm - the priest's ban to go anywhere on Sunday until noon - is not respected. In breach of the ban, the informant and her brother, sent by their mother, went to collect sorrel for soup to the surroundings of a cemetery. This was evidently considered an especially dangerous area, as there the trespassers of the rule faced a sanction: they heard small children crying beneath their feet. This caused such an attack of shivering to the brother that it could only later be stopped by a whisperer (Laime 2011: 176). The crying beings are not identified in the 


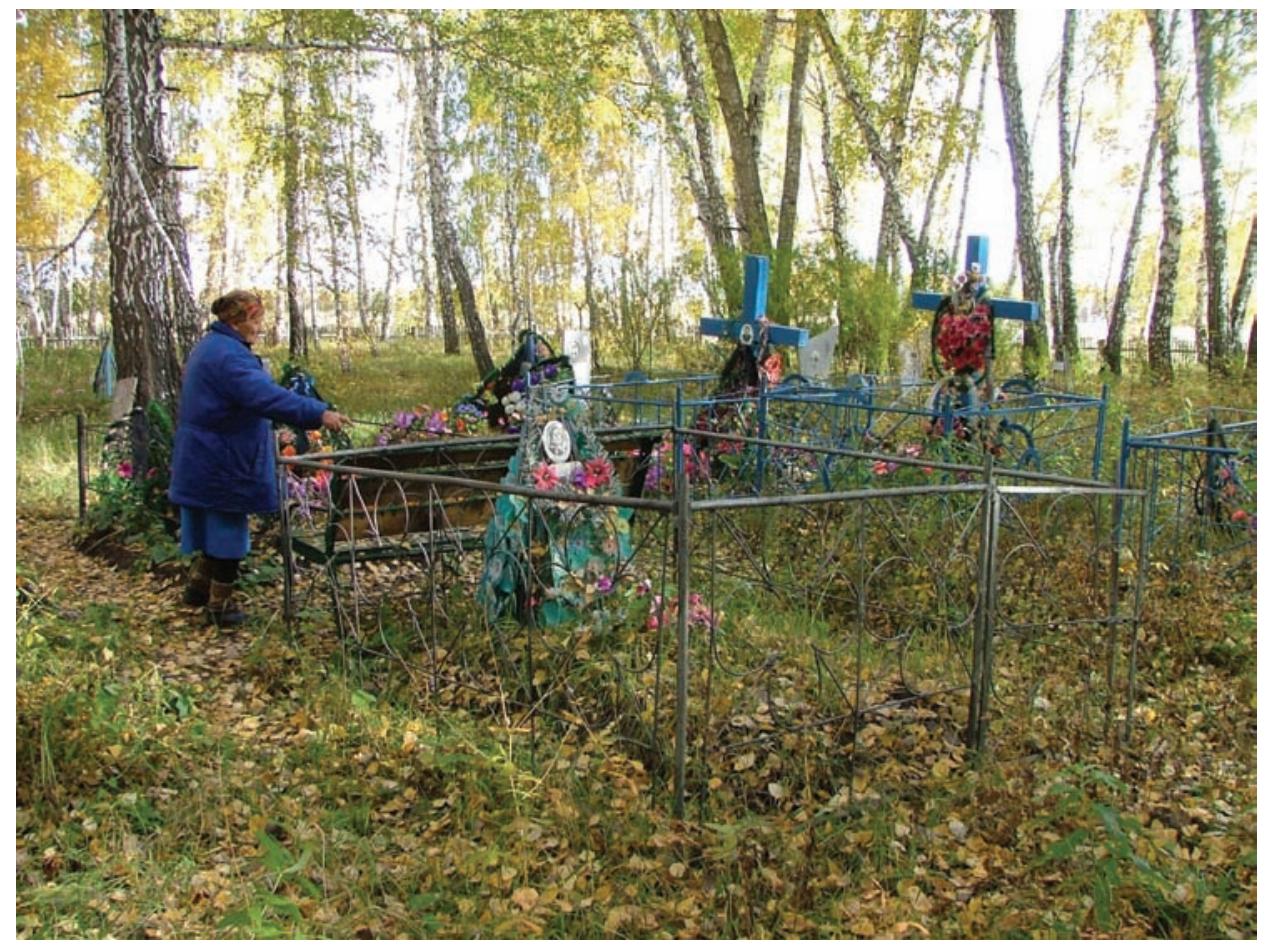

Figure 2. Timofeyevka village cemetery. Photograph by Sandis Laime 2004.

informant's story, and thus they have remained in the state of numen, although it can be assumed that these are souls of the dead. It is significant that the children's cries stopped when the Kopu ryucs stream was crossed. Evidently, the Kopu ryucs stream is regarded as a kind of border between the world of the living and the world of the dead. This is also implied in the cemetery euphemism aiz ryuča (over the stream), which is used in Timofeyevka (Stafecka 2011: 168). When informants say: "Man sen jau laiks doties aiz ryuča" (It is high time for me to go over the stream), they mean that the dying time has come.

The event described in a memorate by Vera Loča (b. 1928) was experienced by her daughter, who one evening had driven past the graveyard to Timofeyevka and seen a person walking out of the graveyard (Laime 2011: 176). In the narration, the informant highlighted twice that the person was dressed in white clothes. Evidently, the situation - a white person walking in the graveyard had seemed strange rather than frightening, as the onlookers had stopped to observe the person. Then the person had begun to rise to the skies, which is a sufficiently convincing sign for the person to be regarded as a supernatural 
being. Interestingly, the informant stressed this feature, repeating the same words again and again: [...] bet tas [cilvēks], skatāmies, cel̦as gaisā. Sāka celties un celties gaisā, augstā $\bar{k}$ un augstā $\bar{k}$, un augst $\bar{a} k$, un augstā $\bar{k}$, un augstā $k$, bet mēs visi skatāmies... (...but that [person] we saw was rising into the air. He began rising and rising into the air, higher and higher, and higher, and higher, and higher, but we were all watching...). The daughter's experience, as is evident from the story by the informant, was immediately discussed at least in the family circle and, explaining this event in the context of the then recent events (funeral of Konstantīns Kravalis's father), the being in the state of numen (person in white clothes) was interpreted as the soul of a specific dead person that transcended from the graveyard to the world of the dead.

The link between memorates and specific objects of the landscape is created over a longer period of time, marking good and bad places in the landscape in the vicinity. It is evident that in the case of Timofeyevka, one hundred years has been too short a period for a broader network of such places to be created around the village. The only such place mentioned in the narratives is the graveyard.

In emigrant villages of Siberia, the documented place-related legends can be subdivided into two parts: those having a plot brought from the homeland, and those that have been adopted from neighbouring peoples in Siberia (see Tuisk 2002: 109). In the oral tradition of Timofeyevka, no localisations of place-related legends known in Latvia were written down although several such narratives have been documented in other Latvian villages in Siberia. ${ }^{6}$

The repertoire of Siberian Latvian place-related folklore is mainly dominated by place-related plots that are known in Siberia. Significantly, in Timofeyevka they are mainly linked to the Tatars. Until the 16th century, when ethnic Russian settlers, including Old Believers, began to appear in Siberia, the Tatars were among the dominating ethnic groups of Western Siberia. Nowadays, only a minority of Tatars living in Siberia are successors of Western Siberian Tatars for the reason that the majority is made up of the Tatars who have moved here from other Tatar-inhabited regions. Legends about the Tatars and other indigenous peoples of Siberia have been borrowed by European migrants from other peoples living in Siberia (Tuisk 2002: 110-113).

According to Bengt af Klintberg, ethnocentric legends constitute one of the contemporary groups of legends. He notes that, when describing foreigners and minority groups in these legends, the lifestyle, values, and norms of the majority are revealed. The depiction of foreign ethnic groups is usually based on ethnic stereotypes, or generalisations, which label the characterisation of the representatives of another ethnic group either positively or negatively. Bengt af Klintberg mentions Swedish legends about immigrants as vivid examples of this legend subgenre (Klintberg 1989: 72-73). This wording can also be turned 
the other way round, i.e., ethnocentric legends may be just as characteristic of the folklore of minority groups, or immigrants, and in this case the subject of legends is the representatives of the dominating nation. These legends, in turn, strengthen the system of values, norms and traditions of the minority, which is especially important if the respective group is small and detached from its ethnic homeland. Such were the settler communities of Latvians and other ethnic groups scattered all over Siberia, living in isolated villages. Aivar Jürgenson notes that the aim of Estonian emigrants, when arriving in Siberia, was not to integrate into the local society, but to create a new, isolated community. In the new environment, the emigrants tried to find or created circumstances that would allow them to continue their homeland lifestyle (Jürgenson 2006: 371-372). Here, one can also refer to emigrants from the territory of Latvia; however, it must be taken into account that, when arriving in Siberia, the settlers did not settle in uninhabited territories.

The Timofeyevka Latgalians consider the Tatars to be indigenous people in the vicinity of their village. This is indicated by several place names and narratives attached to these places. For example, previously, when there were three streets in the village, the one closest to the river was called Tataru ülneica (Tatar Street). Today this street has almost vanished, but villagers still remember its name. There is also a former graveyard named Tataru kopi (Tatar graveyard) on the other side of the River Tartas, which is also indicative of the former presence of the Tatars. The most well-known place connected with the Tatars is Tataru kolns (Tatar Hill). According to legends, it is a place where the Tatars had lived in the past; a former Tatar burial ground; a place where the Tatars buried themselves when the white people appeared, or the white birch trees started to grow in this region; a battlefield where clashes with Yermak's troops took place, etc. (Laime 2011: 179-180).

The Tatars still live in this area. A larger Tatar population resides in the relatively nearby Uluck village, in smaller numbers they also live in other villages. Also two Tatar families have settled in Timofeyevka; this seems to encourage the preservation of Tatar-related legends. It is likely that this topicality was determined not only by the presence of the Tatars in the ethnic composition of the village and the traces they have left in the surrounding landscape, but also by their different appearance, foreign language and religious identity, as well as the unusual way of life and traditions judging from a Latvian point of view.

Among the most evident differences from Latgalians, the Tatars' anthropological characteristics can be pointed out: the dark colour of skin and dark eyes. For this reason, they are called black people, whereas settlers from Europe, including Timofeyevka Latgalians, are referred to as white people: 
Previously, there were Tatars here. When Latgalians arrived here, the Tatars got scared. It's been told that they dug a large pit [on Tatar Hill], covered it with a pole, filled it up and died. They were afraid that the white people had arrived. Here, it's been told, the Tatars lived before us. This street where we live, the Tatars lived here previously, it was a Tatar street. When Latgalians arrived, they ran off-got scared and ran off. ${ }^{7}$

Another significant difference between the Tatars and Latgalians reflected in legends is their religious identity, as Tatars are Muslims. Various Tatar traditions are also related to this. In the narration about Tataru kolns by Vera Kalugina, there is an interesting episode about how the Tatars once hunted wolves on horseback and asked Allah for help:

Tataru kolns - the hill across Magda's swamp is called Tatar Hill. Previously, the Tatars lived here and afterwards left for someplace else. Oh my, how they chased wolves! Riding on horses! They chased them for so long until they tripped. And kept calling: “Allah! Allah!”, but that 'Allah' means 'God' in the Tatar language! So they prayed to God, the Lord to catch and kill that wolf. ${ }^{8}$

The different religious affiliation of the Tatars is also mentioned in a story by Tatjana Peščerska about a Tatar graveyard: it is stressed that the Tatars do not put a cross on their graves, but a pole with a crescent on top of it (Laime 2011: 180). It is also worth mentioning that the graves of the Tatars buried in Timofeyevka cemetery during the Soviet era were also decorated this way. Likewise, Vitālijs Savickis explained that the burial traditions of the Tatars are different in the aspect that before the coffin is lowered into the grave it is wrapped in a cloth (Laime 2011: 180).

With the description of the Tatars who differ from Latgalians anthropologically, linguistically and religiously, these legends mainly unveil the values and way of life that is significant to Latgalians themselves. Consequently, the legends borrowed and adapted in Siberia have strengthened Latgalian ethnic and religious identity.

Although relatively small in volume, the collection of place-related folklore written down in Timofeyevka provides a sufficiently vivid illustration of the conditions for the creation and functioning of different subgenres of placerelated folklore in the oral tradition of Latgalians who have settled in Siberia. On the one hand, various episodes of individual and collective memory have been stored in place-related narratives, on the other, place-related legends have been told to safeguard ethic, religious, social and other norms significant to the community, and to strengthen its ethnic identity. 


\section{NOTES}

1 Latgalians are inhabitants of Latgale, a cultural and historical region in eastern Latvia. They differ from other inhabitants of Latvia in their distinctive linguistic and religious identity: Latgalians speak the High Latvian or Latgalian dialect of the Latvian language and are Catholic (inhabitants of other regions of Latvia are predominantly Lutheran). At the time of migration at the turn of the 20th century, Latgale was a part of the Vitebsk governorate. In Russia, the successors of Latgalian settlers are sometimes considered as belonging to a separate people - Latgalians which is indicated in the data of the Russian national census and the ethnicity entry in passport.

2 The use of personal names and surnames in particular has been the most common way of coining toponyms in Timofeyevka and also in other Siberian villages.

${ }^{3}$ Fieldwork led by Professor Janīna Kursìte was conducted in Timofeyevka in 2004 and 2006 by representatives of the Institute of Literature, Folklore and Art at the University of Latvia, and other research institutions.

${ }^{4}$ Latvian folklore contains evidence about how at the funeral of single young people, their wedding was also celebrated; for example, "the first day of the funeral of single people was called the wedding day and only the second - the funeral" (LTT 2077, Sēlpils); "when the funeral of a young (single) lad or lass is being celebrated, then one says: "Well, today (the first day of the funeral) we will celebrate the funeral and tomorrow (the second day of the funeral) we will celebrate the wedding." The first day of celebrations is passed silently, but on the second day people dance, play games and sing" (LTT 2383, Aumeisteri).

5 Zaimka - 'a shack in which field workers stayed while away from home' (loanword from Russian).

${ }^{6}$ For example, one of such legends has been written down in Sukhonoi (former Sibīrijas Marienburga or Siberian Marienburg), Krasnoyarsk Krai. The legend tells about a sauna that sank into the ground because people had gone bathing in it on a day of celebrations; a big pit that is still visible nowadays has remained in the place of the sauna (Laime 2007: 152-153). Legends about sunken churches (rarely also saunas) are widespread in Latvia; therefore this motive could have been brought to Sukhonoi by Latvian emigrants.

7 Vladimirs Tereško (b. 1939), Timofeyevka, Novosibirsk Oblast > Sandis Laime, 2006 (cf. Laime 2011: 180). This legend plot is known all over Siberia, where it has settled along with the first wave of Russian emigration from northern Russia (see Oinas 1968).

8 Vera Kalugina (b. 1914), Timofeyevka, Novosibirsk Oblast > Sandis Laime, 2006 (cf. Laime 2011: 179). 


\section{REFERENCES}

Blinkena, Aina \& Stafecka, Anna 1995. Latviešu valoda Lejas Bulānā. [Latvian Language in Lejas Bulāna.] In: Vaira Strautniece (ed.) Lejas Bulāna: latviešu ciems Sibīrijā. [Lejas Bulāna: A Latvian village in Siberia.] Rīga: Zvaigzne ABC, pp. 103-126.

Garda-Rozenberga, Ieva 2008. Mutvārdu tradīcija mūsdienās: personīgās pieredzes stāsti. [Contemporary Oral Tradition: Personal Experience Stories.] In: Janīna Kursīte (ed.) Vārkava: Tradicionālā kultūra un mūsdienas. [Traditional Culture and Today.] Rīga: Madris, pp. 140-145.

Honko, Lauri 1989. Memorates and the Study of Folk Belief. In: Reimund Kvideland \& Henning K. Sehmsdorf (eds.) Nordic Folklore: Recent Studies. Bloomington, Indianapolis: Indiana University Press, pp. 100-109.

Jürgenson, Aivar 2006. Siberiga seotud: Eestlased teisel pool Uuraleid. [Linked to Siberia: Estonians on the Other Side of Urals.] Tallinn: Argo.

Klintberg, Bengt af 1989. Legends Today. In: Reimund Kvideland \& Henning K. Sehmsdorf (eds.) Nordic Folklore: Recent Studies. Bloomington, Indianapolis: Indiana University Press, pp. 70-89.

Kursīte, Janīna 2011. Latvieši Sibīrijā: ieskats izcel̦ošanas problemātikā. [Latvians in Siberia: Issues of Emigration.] In: Aigars Lielbārdis (ed.) Latvieši latviešu acīm: Sibīija. Timofejevka. [Latvians about Latvians: Siberia. Timofeyevka.] Rīga: Latvijas Universitātes Literatūras, folkloras un mākslas institūts, pp. 17-28.

Laime, Sandis 2007. Ekspedīcija no Tomskas līdz Krasnojarskai. Atskats uz Latviešu folkloras krātuves 2005. gada Sibīrijas ekspedīciju. [Expedition from Tomsk to Krasnoyarsk: A Review of 2005 Siberian Expedition by the Archives of Latvian Folklore.] In: Baiba Krogzeme-Mosgorda (ed.) Meklējumi un atradumi 2007. [Exploration and Discoveries 2007.] Rīga: Zinātne, pp. 140-155.

Laime, Sandis 2011. Timofejevkas apkārtnes vietvārdu un vietu folkloras vārdnīca. [A Dictionary of Place Names and Place Folklore from the Timofeyevka Area.] In: Aigars Lielbārdis (ed.) Latvieši latviešu acīm: Sibīrija. Timofejevka. [Latvians about Latvians: Siberia. Timofeyevka.] Rīga: Latvijas Universitātes Literatūras, folkloras un mākslas institūts, pp. 175-181.

LTT 1940-1941 = Latviešu tautas ticējumi. Sakrājis un sakārtojis prof. P. Šmits. [Latvian Folk Beliefs. Collected and Arranged by Prof. P. Šmits.] Vols. I-IV. Rīga: Latviešu folkloras krātuve.

Melnalksnis, Augusts 1938. Sibīrija. [Siberia.] In: Vilberts Krasnais (comp.) Latviešu kolonijas. [Latvian Colonies.] Rīga: Latvju nacionālās jaunatnes savienība, pp. 286-342.

Mežs, Ilmārs 2011. Statistiskās ziņas par Sibīrijas latgaliešiem: Timofejevkas etnodemogrāfiskais apskats. [Statistical Information about Latgalians in Siberia: An Ethno-Demographic Survey of Timofeyevka.] In: Aigars Lielbārdis (ed.) Latvieši latviešu acìm: Sibīrija. Timofejevka. [Latvians about Latvians: Siberia. Timofeyevka.] Rīga: Latvijas Universitātes Literatūras, folkloras un mākslas institūts, pp. 67-81.

Oinas, Felix J. 1968. Legends of the Chuds and Pans. The Slavic and East European Journal, Vol. 12, No. 2, pp. 184-198. http://dx.doi.org/10.2307/304259. 
Rozenbergs, Jānis 1995. Vai bija vērts tik tālu braukt? [Was It Worth Going That Far?] In: Vaira Strautniece (comp.) Lejas Bulāna: latviešu ciems Sibīrijā. [Lejas Bulāna: A Latvian Village in Siberia.] Rīga: Zvaigzne ABC, pp. 127-141.

Stafecka, Anna 2011. Timofejevkas īpatnējā leksika. [The Unique Vocabulary of Timofeyevka.] In: Aigars Lielbārdis (ed.) Latvieši latviešu acīm: Sibīrija. Timofejevka. [Latvians about Latvians: Siberia. Timofeyevka.] Rīga: Latvijas Universitātes Literatūras, folkloras un mākslas institūts, pp. 159-172.

Stahl, Sandra K. D. 1977. The Personal Narrative as Folklore. Journal of the Folklore Institute, Vol. 14, No. 1/2, pp. 9-30. http://dx.doi.org/10.2307/3814039.

Tuisk, Astrid 2002. The Place Folklore of Siberian Estonians Today: Reflections of Adaptation. In: Tiiu Jaago \& Mare Kõiva \& Kairika Kärsna (eds.) Lives, Histories and Identities I: Studies on Oral Histories, Life- and Family Stories. Tartu: University of Tartu \& Estonian Literary Museum, pp. 107-130. Available at http://lepo.it.da.ut.ee./ lehti/Oralhistory/1.7.Astrid.htm, last accessed on April 16, 2014. 


\title{
WE HAVE NOTHING TO DO WITH THEM; THEY LIVE WITH THEIR OWN KIND SIBERIAN ESTONIANS' REPRESENTATIONS OF THE NEIGHBOURING TURKIC PEOPLES
}

\author{
Astrid Tuisk
}

\begin{abstract}
This article explores the representations of Estonians, an ethnic group inhabiting West Siberian villages today, of their neighbouring Turkic peoples. I discuss the way that Siberian Estonians describe the representatives of these peoples and their contacts with the latter. The analysis is based on the interviews conducted within folklore collection fieldwork, in which a common question posed by the researcher was: What do you think/know about or what contacts have you had with the representatives of Turkic peoples? Siberian Estonians' representations of the neighbouring Turkic peoples are analysed as a creative process based on tradition and expressed by means of various folklore genres, whereas the meanings and interpretations are connected with the social and sociocultural environment. As the article is concerned with the lore of West Siberian Estonians only, it discusses the ethnic groups inhabiting this particular area - the Kazakhs and the Tatars. ${ }^{1}$
\end{abstract}

Keywords: cultural context, ethnic "other", fieldwork, group identity, Kazakhs, post-Soviet time, Siberia, Siberian Estonians, Tatars

\section{THEORETICAL FRAMEWORK}

In this article I explore the level of everyday life, the way that people coexist day by day, how they distinguish themselves and other ethnic groups. The object of the research is based on an analysis of folklore texts. These materials show how the Estonians who live in Siberian villages describe and see the representatives of Turkic peoples.

Folklore can be used to delineate social and ethnic identity within a group. At the same time, group lore is not something that is clearly definable or everpresent. Relying on Richard Bauman's (1971: 35) concept of 'social base', Dorothy Noyes explicates the role of folklore in the social communication of individuals and groups: 
People were connected to folklore not through the abstract linkage of group to tradition but through empirically traceable instances of performance. To be sure, folklore often thematised communal identity, but rather than expressing a pre-existent identity among insiders, it more often constructed one, aggressively, or humorously, at social boundaries. (Noyes 2012: 14)

Identity can be expressed through stereotypes, folklore texts of different genres, daily events, and narratives heard from other people or from the media. Members of a community share the identity, as well as narratives, motifs, stereotypes and prejudices, all of which strengthen this identity. Community identity becomes an arithmetic total of individual identities (Bauman 1971: 32, 37).

Folklore texts acquire their contents, form and meaning in a specific communication situation and historical-social context. The same stereotypes and motifs may be known among different nations and groups, but the way they are used in a specific context gives us information about the individuals and the group. In folklore studies, this phenomenon is known as recontextualisation: a work of folklore acquires a different meaning in a new situation (Bauman \& Briggs 1990: 72-78). In the framework of the current approach, the texts are placed in a wider sociocultural and political context. Rapid social changes have influenced the lives of today's narrators.

The concept of the Other is increasingly popular in nationalism and ethnicity literature, which usually proposes the existence of one significant Other for any national Self, and this Other is usually threatening and negative (Petersoo 2007: 117). The ethnic Other is related to national identity. The Other, and the imagining of otherness, constitutes an important and integral part of national identity formation. Ethnic and national identities are constantly transforming, and are continually being renewed, reinterpreted and renegotiated according to changing circumstances and interests. As Edward Said notes: "Each age and society recreates its Others" (cited in Petersoo 2007: 118).

The boundaries between "us" and "them" are often maintained through basic oppositions. Opposing Us (the Self), and Them (the Others) means choosing a criterion that allows the humanity to be divided into two groups: one that embodies the norm and whose identity is valued, and the other that is defined by its faults, devalued and susceptible to discrimination.

In folklore the ethnic Other is created in many ways. In jokes, the primary mechanism is the creation of a strategic opposition between "good" and "bad", and everything that falls under that division (Laineste 2008: 25). Folk beliefs about exotic foreigners are historically established by using the following contrasts: supernatural versus natural; chthonic or underground versus abovethe-ground, Urvolk or autochthons versus moderns, pagans versus Christians, 
nature versus culture (cited in Kalmre 2013: 67). Very important oppositions in all cultures are purity and dirtiness.

The folklore of Siberian Estonians presents several stereotypes and prejudices about the Turkic peoples. Folklore helps to establish and shape stereotypes, and provides one of the principal sources for the articulation and communication of stereotypes. The lore of different peoples is based on ethnic (national) stereotypes (Dundes 1996: 22-24). Although each stereotype contains a grain of truth, in most cases they reflect generalisations, the aim of which is to disparage the target group exposed to ridicule. For example, in ethnic humour the features inherent in a nation are discarded and habitual debasing characteristics are assigned to various (minority) groups (Draitser 1998: 17-21).

The contact hypothesis suggested by Gordon Allport argues that people are prejudiced against the unfamiliar. Closer contacts between people promote mutual understanding, as people get to know each other better (Allport 1958: 250-267).

The target group of my research is rural population and the way that people living in villages see one another. It is also necessary to describe the macrolevel, that of the activity and ideology of the state and local authorities, as this shapes and exerts influence on inter-group attitudes and values, especially under the totalitarian system, as it was in the Soviet Union (Kuutma \& Seljamaa \& Västrik 2012: 50-52).

\section{MATERIAL COLLECTION}

Fieldwork in Estonian settlements in Western Siberia was carried out by folklore researchers of the Estonian Folklore Archives ${ }^{2}$ in 1993-2004. During the collecting expeditions, which lasted for about a month at a time, 2 to 4 members of the fieldwork team visited different villages, which were usually situated close to each other (Korb 2007: 153-156; www.folklore.ee/estonka/).

The methods of data collection were interviews and conversations, as well as participant observation, and, depending on the situation, these were combined. Communication with the villagers was carried out on a variety of topics, without focusing on any of them particularly. Data were frequently collected by means of interviews, which were combined with a variety of other methods. Some interviews were conducted during meals, and resembled friendly conversations rather than formal interviews. It has to be remembered that in Siberian villages collectors found themselves in an unfamiliar environment: they were literally in the role of guests, and were expected to share news about life in Estonia (Korb 


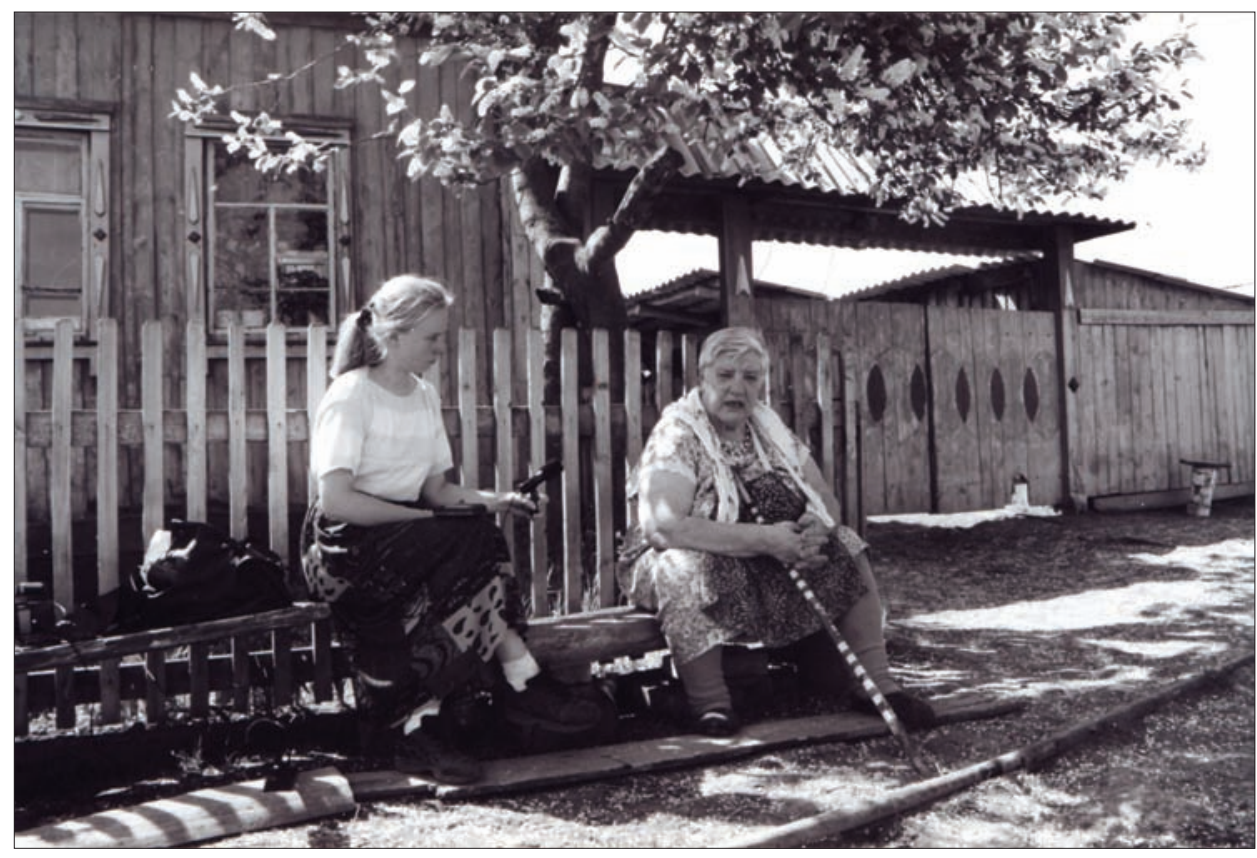

Figure 1. Folklorist Astrid Tuisk interviews Taresa Menskaya. Nikolaevka village, Novosibirsk Oblast. Photograph by Andres Korjus 1999. ERA Foto 16380.

2004: 102-104). I call the villagers whom we met and interviewed conversation partners and narrators, to further emphasise the cooperation aspect and partnership within the fieldwork.

The topics of our conversations varied considerably, ranging from various folklore genres - songs, tales, accounts of religion and tradition - to daily life, literature in the Estonian language, etc. If the conversation happened to reveal the narrator's favourite subject, it was discussed at more length. ${ }^{3}$ In the article I use sound recordings, their transcriptions, and recorded texts, also taking into consideration their context.

One of the topics that was discussed touched upon the surrounding ethnic groups, their traditions and customs, and the Estonians' contacts with them. The topic often emerged naturally, without leading questions from the part of the collectors. Anu Korb (2007: 63-66) argues that in a multicultural environment, the emergence of a specific topic is to be expected, and describes a specific situation to give an example. 


\section{COLONISATION OF SIBERIA}

Siberia is a geographical region extending from the Urals in the east to the Pacific Ocean, and from the Arctic Ocean to Kazakhstan, Mongolia and China. In the course of time, the political and administrative borders of Siberia have undergone several changes. Siberia has a long and colourful history. In view of the current topic and especially considering the relationship between the Russians and the Tatars, special mention must be made of the Golden Horde, a Mongol Khanate in the 13th-15th centuries, the Siberian Khanate, which was established in the 15th century and occupied by the Russian Empire in the late 16th century, as well as the Russian colonisation and the resulting incorporation of Siberian territories into Russia. After the so-called Great Migration in the 19th and early 20th centuries, Siberian indigenous peoples were banished to the remote areas; they were either charged with taxes or exterminated, and the policy of Christianisation and Russification was carried out (Slezkine 1993: 15-27; Kappeler 2001: 189-190; Jürgenson 2008: 119). Due to the process of colonisation and settlement, Siberia became an integral part of Russia, which was inhabited overwhelmingly by Russians (Goryushkin 1991: 155). After colonisation, the relative importance of Siberian indigenous peoples decreased considerably.

3.8 million people, largely from the European part of the former Tsarist Russia, migrated to Siberia and the Far East between 1861 and 1914 (ibid.: 140). Estonians were among the many peoples who settled down in Siberia and established villages, some of which still exist with a population that has stayed there for many generations.

At the end of the 19th century, the largest group of non-Slav population in Western Siberia was constituted by the representatives of different Turkic (in the then approach Tatar) peoples. Their total number by the census of 1897 amounted to 152,558 people, including Bukhara and Tobolsk Tatars and Tatar peasants (Korovushkin 2009: 55).

Siberian Tatars and Kazakhs regard themselves as indigenous; yet, the migrants also claim their right to the land in Siberia. Even today the contradiction between the indigenes and migrants caused by the right to land is a significant impact factor in the inter-nations relationship. Researchers have also been interested in this topic. 


\section{SIBERIAN ESTONIANS}

The Estonians in Siberia, on whose narratives my article is based, have inhabited Siberian villages already for several generations. In 1926, 29,890 Estonians lived there (Perepis 1926; Korovushkin 2008: 101). According to the population census of 2010, about 7000 Estonians resided in Siberia, whereas a sizeable part lived in the cities (Perepis 2010). The oldest West-Siberian villages with the greatest number of Estonians are the ones to which those convicted of crimes were deported (Ryzhkovo, Staryi Revel) (Must 2012: 305-361, 348-353). Later on, a large number of voluntary immigrants settled down in both of these villages, as well as established some new ones. These villages are scattered all over Western Siberia, in places also several villages near one another, like in the Omi settlement or Tara region (Nigol 1918: 40-54; Kulu 1997: 84-104; Korovushkin 2008: 148-165). Side by side with the villages inhabited by Estonians, there are also the ones established by immigrants of other nationalities - Russians, Latvians, Poles, Byelorussians, Ukrainians, Chuvash - as well as Tatar and Kazakh settlements. Initially, different nations and ethnic groups in Siberia resided in different villages or parts of villages. Nowadays the communities are clearly multi-cultural and multi-ethnic.

\begin{tabular}{|c|c|}
\hline Year & $\begin{array}{c}\text { Number of Estonians } \\
\text { in Omsk Oblast }\end{array}$ \\
\hline 1926 & 6773 \\
\hline 1939 & 7005 \\
\hline 1959 & 6053 \\
\hline 1970 & 5160 \\
\hline 1979 & 4544 \\
\hline 1989 & 4069 \\
\hline 2002 & 3025 \\
\hline 2010 & 2082 \\
\hline
\end{tabular}

Table 1. Changes in the number of Estonians in Omsk Oblast, 1926-2010 (Kulu 1997: 154; Perepis 2002; Perepis 2010).

The majority of the elderly Estonians, who used to live in the villages at the time when the interviews were carried out, regard themselves as Siberian Estonians (Jürgenson 2002: 272-273). Ilia Lotkin (1996: 97) argues that the 
Figure 2. The older generation values traditions. Olga Ojaperv sitting behind a spinning wheel. Nikolaevka village, Novosibirsk Oblast. Photograph by Astrid Tuisk 1999. ERA Foto 16376.

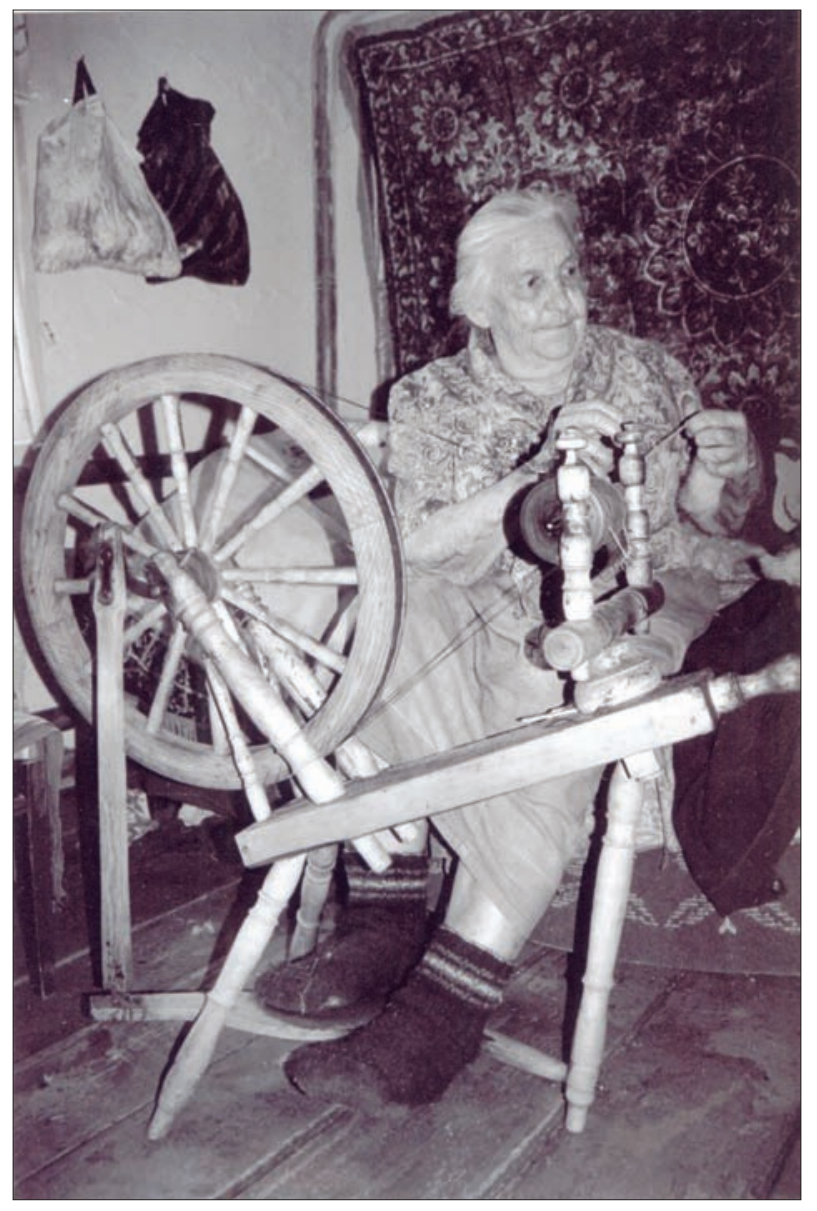

language barrier between different nations was liquidated by the $1960 \mathrm{~s}$. The overall incursion of the Russian language started in the 1930s, when the Estonian language was ousted from public life by retaliatory measures imposed by the state. Mass bilingualism under the conditions of diglossia started to take root (Viikberg 2010: 541). So a hybrid identity evolved: people could simultaneously identify themselves in many ways, for example, as residents of Siberia, Russian citizens, etc. (Jürgenson 2002: 259-269; Korb 2010: 27-28).

Estonians are Lutherans by their confession. Today people's attitude towards religion is different: elderly people still regard themselves as Lutherans. Others, although they regard themselves as believers, think that it is irrelevant what their concrete belief is. They go to the Orthodox Church and keep icons at home. There are also some people who are atheists (Viikberg 2010: 527). 
The material that is analysed in this article was collected from elderly Estonians who live in these villages and still speak Estonian. The opinions of younger Estonians and those who live in urban areas have been left out. Expeditions to the Estonian villages in Western Siberia took place in the years 1993-2004; the respondents were people whose birth year was from 1910 to 1940 and the collected material consists of 60 interviews. For the sake of fluency, I hereafter refer to my narrators as Siberian Estonians, although, as was mentioned above, the opinions under consideration do not involve those of all Siberian Estonians.

\section{TURKIC PEOPLES IN WEST-SIBERIAN STEPPE AND FOREST-STEPPE AREAS}

\section{Siberian Tatars}

Siberian Tatars are not a uniform consolidated nation. The Tatars inhabiting Siberia can roughly be divided into three groups: local, so-called Siberian (Tyumen, Tobolsk, Tara, Barabinsk, etc.) Tatars, early migrants, and more recent resettlers (Ishakov 2001a: 23-25). The more recent resettlers are, for instance, Volga-Ural Tatars, whose migration to Siberia gained impetus at the end of the 19th century. So, local and immigrated Tatars have finally merged, although initially new immigrants settled down either in separate villages or parts of villages (Valeev \& Tomilov 1996: 35-37, 78). The descendants of the Tatars who migrated to Siberia from the other side of the Urals regard their ancestors as Russian Tatars, whereas locals consider themselves indigenous Siberian Tatars (Korusenko 1999: 40). People were mainly engaged in stock raising, but also agriculture, hunting and fishing (Halikov 2001: 162-174). Tatars are Muslims (Sunnites), and there are mosques in the villages of Siberian Tatars.

\section{The Kazakhs}

The Kazakhs (until 1924 the Kazakhs were mistakenly called the Kirgiz in Russia (Kappeler 2001: 186)) were one of the most numerous ethnic groups of West-Siberian Turkic peoples. According to the census of 1897, their number in Tomsk and Tobolsk districts amounted to 32,357 (Korovushkin 2009: 56). Similar to the Tatars, the Kazakhs are also Muslims.

The single most important factor in the Kazakhs' history was the nomadic lifestyle. The Kazakhs had a pasture-based economy that involved seasonal 
migration: in the summers they moved to the northern edge of the steppe (southern Siberia and the southern Urals), and in the cold winters to the more southern areas. Their most important possession was herds of horses, sheep, goats and, more rarely, cattle, and in the south also camels (Kappeler 2001: 185-186).

As was the case also with other nomads, the settlement of pasturelands by migrated arable farmers from the European part of Russia became a decisive destabilising factor for the Kazakhs. It caused considerable changes in the Kazakhs' social structure and, in the 19th century, made part of them settle down permanently. The majority of the Kazakhs still pursued their traditional way of life and this provoked conflicts between the immigrants and the local Kazakhs; for example, the 1916 uprising. In the 1930s, repressive power measures were implemented by the state to finally establish coerced residency of the Kazakhs (ibid.: 189-190).

\section{ATTITUDE OF THE RUSSIAN TSARIST GOVERNMENT AND SOVIET AUTHORITIES TOWARDS SIBERIAN ETHNIC MINORITY GROUPS}

In the 19th-century Russia, ethnic groups, including those in Siberia, were regarded as inozemtsy (people of a different land), or as inorodtsy (people of a different birth), and sometimes also as inovertsy (people of a different faith) (Grant 1993: 230). Yuri Slezkine maintains: "It was now their overall cultural distinctiveness - or rather, the growing perception of their 'backwardness' that made people alien" (cited in Grant 1993: 230).

Estonians, and especially those who live in Russia, have also been regarded as inorodtsy. At some point in time, this term was taken into use to designate all the people in the Russian Empire who were not of Russian origin (Kappeler 2001: 171). Similar to other minority groups, they have been forced to abandon their rights to having newspapers and schools in their mother tongue, have been subjected to repressions, etc. Estonians and also other Finno-Ugric peoples have been called by a nickname chukhontsy or chukhna, which has a slightly pejorative connotation (Must 2012: 322).

The same topic was also followed by the Soviet authorities, who continued talking about Siberian indigenous peoples and other small nations in general as "being underdeveloped", as well as about their "primitive social" formation. This policy was aimed at shaping a new unified Soviet nation (Grant 1993: 227-228; Diment \& Slezkine 1993: 5; Kappeler 2001: 190). In the years of 
economic depression, 1968-1979, Soviet authorities were characterised by an especially passionate xenophobia (Draitser 1998: 19).

The Soviet nationality policy has been described as ambivalent:

The Soviet government pursued a dual course toward its minorities, enacting assimilationist policies at the same time as it maintained and even strengthened the ethnic institutions that were established in the $1920 \mathrm{~s}^{4}$. The slogan "national in form, but socialist in content" symbolises this dual approach. [---] Officially, Russian was labelled as the language of interethnic communication, but speaking Russian became an essential element of participating in Soviet society. (Gorenburg 2006: 273-274)

As Estonian linguists have argued, for an ethnic minority group, the mother tongue is a functional language of a non-official status, used only at home. National culture was allowed to be "presented" only by folkloric groups at concerts. In towns, outside of villages, and in multi-ethnic schools, the use of the mother tongue was rather condemned than favoured (Viikberg 2010: 528-529, 541). Also, Gorenburg holds that, as regards the ethnic and linguistic identity of ethnic minority groups, the Soviet Russification policy was successful, "especially among younger cohorts who had grown up in a Russian linguistic environment and were much more likely than their elders to claim Russian as their native language or to change their ethnic identity to Russian" (Gorenburg 2006: 299).

After the collapse of the Soviet Union, minority groups in Russia have once again started to identify themselves. Ergo-Hart Västrik, for example, has discussed the reidentification of the Votic identity in villages (Kuutma \& Seljamaa \& Västrik 2012: 64-68). Several national and cultural societies have been established, and people are trying to find their roots; for instance, the Tatars restore their mosques and teach their children to speak and write Arabic (Ishakov 2001b: 520-522). However, the state favours the minority groups' cultural activities rather than their political self-determination.

\section{ETHNONYMS}

Similar to other migrants, Estonians in Siberia do not use loan ethnonyms, such as tatarlane (a Tatar), kirgis (a Kirgiz) and kasak / kasakas (a Kazakh), to signify the corresponding ethnic groups. Both kirgis and tatarlane are rather used as common names marking different Turkic peoples inhabiting Siberia and Central Asia (e.g., the Kalmyks). The semantic field of the Estonian ethnonyms kirgis and kasakas is partly overlapping, with both names designating 
the ethnic group of Kazakhs (Korovushkin 2009: 56; Kappeler 2001: 186). This is mainly because until 1924 the Kirgiz and the Kazakhs were mistaken for a single ethnic group in Russia. The ethnonym kasakas is used only by the Estonians of the Tsvetnopolye village, which is located in the immediate vicinity of Kazakhstan. The semantic field of the ethnonym kirgis is considerably broader and more ambiguous. In the folklore of Siberian Estonians (and in this article) the word kirgis denotes mainly the Kazakhs, or is used as a generic name for different Turkic peoples. The Kirgiz as an ethnic group are not discussed in the current article.

\section{ANALYSIS OF THE MATERIAL}

Turkic peoples occur in Estonian children's cautionary tales as well as in nicknames, mocking verses and historical narratives. Also, they are mentioned in connection with mixed marriages and the population of the villages becoming multi-ethnic. Often enough they simply describe a diverse way of life and different customs.

Different Turkic peoples occupy an important place in Siberian Estonians' conceptions of the Other. Among the Other, Siberian Estonians often include Russians and Gypsies. People live in the same villages and communicate closely with their neighbours - Lutheran Germans, Latvians and Finns - while in folklore and as representatives of foreigners the latter occur less frequently than the Turkic peoples. On rare occasions the Chuvash, Komi, Khanty and other Siberian indigenous and immigrant peoples are mentioned.

In folklore texts both negative and positive features are pointed out; yet, differences rather than similarities are described. The scale of attitudes is comprehensive, ranging from positive descriptions (a good people) to neutral, and even to fear and loathing. Positive attitude is revealed in some descriptions that explain strange behavioural features, different than those of Estonians. These texts could rather be called neutral, because they do not tend to depict a positive, even romanticised child of nature, as occurred, for example, in the treatments of Siberian indigenous peoples in the 19th century (Diment \& Slezkine 1993: 4). However, in connection with language skills, it has been mentioned that knowledge of several languages (including Kazakh) is instrumental. 


\section{Historical narrative}

Estonian folklore is not related to the earlier history of Siberia (with the exception of its settlement history).

According to West-Siberian Estonians, they came to an "empty place". Aivar Jürgenson calls it a pseudo-historical myth, which ignores the former history of the settlements and is therefore not politically correct (Jürgenson 2011: 145). However, there is actually no controversy between these two versions, one of them claiming that other people lived there formerly, and the other stating that people came to an empty place. "Emptiness" is to be construed in a wider sense with regard to one's own culture, not merely concerning the cultivated land and built houses. The history of the area begins with the creation of the area's own culture: "The history of a settlement is frequently just the history of the settlement itself' (Jürgenson 2011: 145). The 'Us'-group is depicted as giving content to the empty land, whereas the Others destroy the created structure.

Nor does the following example pose a question about who has the right to live in this particular place:

All the lands here were empty and barren. Here lived those from Kazakhstan, or, those Kirgiz. They had 'volju' [were arbitrary, powerful], they had large studs and herds of sheep. They would not go away. Now, wherever you look (not any more, all the holes are closed now), there is again a Kirgiz well, again a waterhole. [---] But they just wouldn't leave; eventually they were driven away, their semlaks (sod huts) or whatever they had there were demolished and then the land was given away.

ERA, CD 413 (26) < Rozental village, Novosibirsk Oblast < woman, born about 1925 (1999).

Stories about the foreign people who resided on the village sites before the arrival of migrants originate from a common local source. This example originates in a so-called 'Kerzhak' settlement of Russian Old-Believers in Novosibirsk Oblast: "There were some non-Russians here, but we, Russians, came, took charge of them and drove them out" (Baituganov 1998: 71). Today Estonians maintain that they came to Siberia only to "get land and freedom"; yet, in their attitudes towards the neighbouring peoples they take the same position as the other immigrants. This kind of attitude and the official colonial policy created a favourable ground for mutual misunderstanding between different peoples. 


\section{Narratives about everyday happenings, different habits and customs}

The narratives mainly speak about everyday happenings, as well as different habits and customs. The stories are based on real contacts with a person/people of a different nation, with whom meetings have taken place, although sometimes very briefly. These texts describe encounters at fairs, or how the Tatars and the Kirgiz/Kazakhs came to villages to buy and sell sheep, salt and other goods, or how they just passed through.

- But here in these steppes the Kazakhs once lived.

- For some reason or other, they always passed through this village (Tsuetnopolye) on their camels.

- They sold this white clay and...

- Brought salt and... They had such big leather sacks with salt with them, tied on camels' backs, on either side. There is this salt washing place in Kazakhstan, and they drew salt from there and traded it.

ERA, CD $2(26)<$ Tsvetnopolye village, Omsk Oblast < village women (1997).

One of the traditional activities of the Kazakhs was merchant transport from European Russia to Central Asia; for example, they bred camels to transport salt through Siberia and the Urals. The Kazakhs, as well as other peoples, also traded horses.

Turkic peoples, like the Kirgiz and the Kazakhs, appear in children's cautionary tales. Scaring children with someone of a foreign nation is highly customary. In the Estonian tradition, scaring children with Gypsies and peddlers who went from one village to another and were often of foreign origin was a common practice. The travelling lifestyle, the sudden appearance of caravans, which came from and left for a distant unknown place, and the big sacks carried around generated various superstitions and children's cautionary tales about strangers, about the Others. The cautioning formulae are quite typical: A Kirgiz will come and take you away.

In the folklore of Siberian Estonians, the Kirgiz and the Kazakhs have not replaced Gypsies, but they appear side by side:

Villagers were very afraid of the Gypsies and the Kirgiz. They told [the children]: "Go to sleep, or the Gypsies will come!"

EFA I 35, 18 (5) < Rusko-Semenovka village, Novosibirsk Oblast < man, born in 1927 (1998). 
A mocking verse recited to the Kirgiz and the Kazakhs exemplifies the creativity of Estonians. The verse seems to be based on a borrowed text, which has been adapted or translated into the Estonian language. The words have been chosen to match the rhythm and form an end-rhyme.

Kirgis, kirgis, kilmandaa,

Sõitis kireva lehmaga!

[Kirgiz, Kirgiz, kilmandah,

Rode a dappled cow!]

ERA, CD 280 (25) < Nikolaevka village, Novosibirsk Oblast < woman, born in 1917 (1999).

When we were children, the Kazakhs rode here on horseback. And we sang:

Kasak, kasak, kilmandaa,

Viska sitta silmaga!

[Kasakh, Kasakh, kilmandah,

Shovel shit with your eye!]

And ran back indoors, closed the latch so that the Kazakh wouldn't catch us.

ERA, CD 14 (23) < Tsvetnopolye village, Omsk Oblast < woman, born in 1939 (1997).

Mocking verses and cautionary tales are specified in the form and they reveal a group-centred point of view. We cannot state with certainty that Estonians' attitude was patronising, as could be assumed by the sayings, children's cautionary tales and historical narratives.

The boundaries are maintained by means of basic oppositions. The lifestyle fostered by the Turkic peoples, for example the Kazakhs, their living in yurts and engaging in nomadic herding, was clearly different from the sedentary life of villagers and prepared the ground for the emergence of various stereotypes, such as the opposition of the savage/civilised nation. The Kazakhs and other ethnic groups were forced to lead a sedentary life and settle in villages after the establishment of the Soviet regime. This way the stereotype of the savage/ civilised nation was also strengthened by the governing rule that disapproved of the nomadic herding life.

In general terms, Estonians in Siberia perceive the neighbouring Turkic peoples negatively as strangers, even though the negative perception is not identified with hostility. However, foreigners are often laughed at or ridiculed and given nicknames. 
Universal mocking could indicate serious hostility; yet, it could also be created as a means of entertainment and for making fun of somebody. Although some of them are fairly sharp ("shovel shit with your eye"), they are not very common among Estonians. In contrast, the Russians have plenty of folklore sayings, nicknames and proverbs associated with the Tatars (Draitser 1998: 115-116; Dal 1957).

As already mentioned, Estonian folklore is not related to the earlier history of Siberia. Contrary to Estonian folklore, in Russian folklore Turkic peoples have deep roots and a historical background. Therefore sayings, nicknames, and children's cautionary tales occur sporadically and they do not feature such a deep significance as in Russian folklore.

\section{STEREOTYPES}

Conceptions of the Turkic peoples are based on several specific stereotypes. Stereotypes and prejudices are connected with horses: selling horses, riding horses, and eating horse meat. The most frequently occurring theme in the stories of Estonians in Siberia is eating habits. Religion has been an important factor shaping different culinary traditions, and, naturally, plays an important role in the differentiation between "us" and "them". The traditional Islamic dogmas of the Sunni Muslims (Kazakhs, Tatars, and others) prescribe strict culinary restrictions, such as banning pork and alcohol, and preference for horse meat and lamb products. The tradition is no longer strictly followed in Siberia, but in Tatar families ethnic foods are still prepared according to traditional recipes (Valeev \& Tomilov 1996: 106). The Kazakh ethnic cuisine also includes camel milk products, such as kumiss ${ }^{5}$.

The Tatars don't have such a table, or a bed, they sleep on polots (bunk beds). And sit with their feet under the butt, that's why their legs are crooked. And they didn't eat pork. They brought along horse meat, horse sausages to Maali's place. They had no minced meat, only these big pieces. EFA I 18, 37 (1) < Lileika village, Omsk Oblast < village women (1996).

Apart from the lifestyle, stereotypes were also associated with physical appearance: crooked legs, slit eyes, dark skin, and the more general stereotype of dirt and bad odour.

Representatives of a foreign group are traditionally depicted as filthy, unkempt, and smelling badly (Douglas 2002 [1966]: x-xii, 2-7). These stereotypes occur in Verkhnii (Upper) Suètuk Estonians in Krasnoyarsk Krai, who live side 
by side with the Khakas and the Tuva (Tuisk 1999: 89-91). For example, there is a story about a Tuva girl who had never been to sauna:

- Ruosi of Tihu told me, they were in Tuva and, you see, the Tuva had never been to sauna. Said that a young girl, Mannu of Mõistiku, was there and the Estonians of our village were and lived there. And well, once they had taken her to the sauna by force, the 17-year-old said, pulled her by force, many of them, and took her to the sauna and heartily whisked her and bathed her... And the next Saturday she came herself... [Laughter]

- Who was that?

- A Tuva girl.

- But before that she didn't know [the sauna], smelled like a horse.

RKM, Mgn. II 4371 (22) < Verkhnii Suetuk village, Krasnoyarsk Krai $<$ people of Verkhnii Suetuk village (1992).

Real life contacts, closer relations between different ethnic groups, and getting to know one another refute the stereotypes and change ethnic attitudes towards the Turkic peoples. The following is a narrator's response to the researcher's question about what people thought of the Tatars. As the narrator speaks quite adeptly about the Tatars' washing habits, we could presume that she has had some first-hand experience in it. It is good to remember that the story was recorded in Nikolaevka village in the northern part of Novosibirsk Oblast, now populated by the local Baraba and other Siberian Tatars.

There are many Tatars here, the Tatars were and lived even here, in our village. The Tatars did nothing bad, they held on to their faith. Ate horse meat and... You see, when he went to the outhouse, he took along a towel and a water jug and all. Was holding the jug, this iron jug all the time. Had it ready, water inside, so as soon as he had to go, he took the jug along. So he washed himself over there and. But the Estonians, or the Russians, did not have such a custom.

ERA, CD 280 (25) < Nikolaevka village, Novosibirsk Oblast < woman, born in 1917 (1999).

Although this narration is not presented in a negative key, the narrator regards the different custom of another nation so remarkable that it is worth mentioning.

In general terms, Estonians in Siberia perceive the neighbouring Turkic peoples negatively as strangers, even though the negative perception is not identified with hostility. Instead, foreigners are often laughed at or ridiculed. Thus the term 'adversary' seems more appropriate in this case than 'negative stranger'. An ethnic group constructs an antagonist to whom they oppose them- 
selves. Although descriptions of another nation have not always been presented in a negative key, they still speak about a foreign people different than us.

For Estonians in Siberia the Turkic peoples occupy an important place in conceptions about the Others and thus they have been labelled with several specific and general stereotypes. The more frequently recurring themes in the narratives of Siberian Estonians are the eating habits, the religious practices, and the lifestyle of the other ethnic groups. Quite widely practiced is the cautionary formula told to misbehaving children - "A Kirgiz will come and take you away!" - and the alleged practice of the Kirgiz to kidnap children (which will be discussed below).

One's own ethnic identity is built up on the opposition to another nation. For the Estonians in Siberia, the folklore and perceptions about different Turkic peoples are important for self-identification and categorisation of the neighbouring ethnic groups. It also helps the Estonians to formulate one of the main questions, the master narrative, of their history: Who are we on this Siberian land? This is one of the ways to talk about history and identity.

\section{INCREASING INTERGROUP CONTACTS}

Certain texts manifest outright hostility and fear. It is shown in people's attitudes and opinions, which, however, are not in correlation with one another. People's opinions can be transformed, for example, on the basis of education. However, Allport maintains that the best way to change people's attitudes is through personal contacts (Allport 1958: 250-267). Yet, he also claims that increasing intergroup contacts may reinforce negative prejudices.

Explicit dislike for the Turkic peoples can be expressed in connection with mixed marriages and multi-ethnic villages. In these contexts the names 'Kazakh' and 'Tatar' are used as generic names for another, foreign nation, rather than to denote a member of a concrete ethnic group:

- Orava village used to be a real Estonian village, yet now it abounds with the Kirgiz and the Kazakhs.

EFA I 19, 90 (3) < Novyi Revel village, Omsk Oblast < woman, born in 1916 (1999).

- I agree to everything, but not have a Kazakh in my home [as a son-inlaw]!

EFA I 20, 15 (4) < Tsvetnopolye village, Omsk Oblast < women, born in 1937 and 1939 (1997). 
- They have wrecked the Estonian village, the Tatars and the Setus are coming in.

EFA I 18, $126(17)<$ Mikhailovka village, Omsk Oblast < woman, born in $1920(1996)^{6}$.

It is true that in the course of time the settlement pattern of Siberia, as well as the closeness of intergroup contacts, has undergone changes; for example, as concerns different nations residing in different villages or parts of villages. In connection with the establishment of kolkhozes in the 1930s, both farmsteads and villages were concentrated in the central settlements of kolkhozes. The 1960s witnessed the launch of a campaign to expand collective farms and abolish small, so-called 'unpromising' villages in Western Siberia. People moved to larger, 'prospective' settlements, which, as a result of migration, developed a multi-ethnic population (Lotkin 1996: 35-65). These processes concerned the villages of both the Tatars and Estonians, as well as the Kazakhs' settlements.

By today the proportion of Estonians has decreased in practically all the Estonian villages in Western Siberia, exceeding $60 \%$ only in small villages in the periphery.

In 1927, 488 people lived in Orava village (Korovushkin 2008: 151); by 1989, the number had decreased to 154, 70\% of them being Estonians ${ }^{7}, 18 \%$ Russians and 10\% Germans. Most probably, it is the number of Russians that has increased in the village, not that of the Kirgiz and the Kazakhs.

Tsvetnopolye ${ }^{8}$, which was an Estonian-German village, was merged with a Kazakh settlement; the Kazakhs have also moved to Ryzhkovo village. Yet, according to statistical data, in the late 20th century the Kazakhs did not constitute the majority in any former Estonian village (ibid.: 191-193). Although some Kazakhs and a few Tatars have moved to Estonian villages, the majority of newcomers of other nations in the villages are Russians.

The situation with marriages is the same. Already beginning in the $1940 \mathrm{~s}$, West-Siberian Estonians married people of other nations (mainly Russians) rather than their own compatriots (Lotkin 1996: 134-137; 168-172).

Today, villages and families of single ethnicity are largely a thing of the past. Increasingly closer cross-national communication and multi-ethnic villages have become a reality. The current older generation is socially active and political changes have been rapid.

Folklorist Eda Kalmre has studied rumours about sausage factories, which were told in Tartu after the Second World War. When the Soviet rule was established in Estonia, there was much violence related to the state of war and repressions. The social structure of the population changed radically: new people, predominantly immigrants, occupied the position of power. All the fears associated with lack of food became mingled, and, as fear of a foreign people is 
related to their eating habits, sausage made of horse meat was unacceptable and unappetising for Estonians also at that time (Kalmre 2013: 81-84). This urban legend expressed the community's attitude towards an alien culture, but also testified to the fact that "malevolent savage Others may take control and impose their savage ways on everyone" (Kalmre 2013: 94-95).

The mixing of different fears and dread of strangers can also be detected in the current narratives of the Turkic peoples. The older generation often has the task of embedding social norms about what kind of behaviour is appropriate and what is disapproved. In addition to the disappearance of own language and culture, the informants have found it problematic to accept and adapt to the foreign culture. In contrast to one's own group, a stranger (intruder) is a threat to the stability and existence of the group.

\section{INDIVIDUAL MEETINGS WITH TURKIC PEOPLES}

More idiosyncratic traits are added to the descriptions when people talk about their personal contacts with the members of the said ethnic group. These are memorates that describe personal experiences and emotions, including fear.

The folklore materials of West-Siberian Estonians present a range of examples in which close but cursory contacts with another nation have caused apprehension.

Several women (for example, from the villages of Staryi Revel, Rozental and Orava) claimed to have been seriously afraid of the Kirgiz. Often the fear is reflected in the stories from their childhood or youth.

- But have the Kirgiz been here as well?

- There used to be an awful lot of Kirgiz after the war. They ate, abducted children and ate them. And when Mom left for work, I was afraid. Usually there were no curtains or anything covering the windows, so we hid behind the oven and under the bed and wherever. Then they banged at the doors and sometimes were behind the windows and, you know, smashed doors and. We feared these Kirgiz, there were so many of them and they were hungry. Went to all the houses in the village for anything they could lay their hands on.

ERA, CD 414 (11) < Rozental village, Novosibirsk Oblast < woman, born in 1935 (1999).

The next narrator worked as a cook at a kolkhoz with multi-ethnic population.

- But then didn't want [to marry] a person of another nationality [---]

- No, I am terribly afraid of the Kirgiz, oh, oh, oh, oh. 
- We had here in our field camp, I was there in 1947, I was at the field camp, I was the cook there. And then this Kirgiz wanted to snatch me, wanted to abduct me, one of these boys. I am going to take you with me, going to take you away and that's it.

We often went there [to the Kirgiz]. "Dochka, ty kumys khochesh'?" [Darling, would you like some kumiss?] I answered: "Net, net, net, net" [No, no, no, no]. This drink made of mare's milk. You know this kumiss, don't you?

- Yes, I've heard about it, yes.

- But I've actually seen it. They say that there are worms on the bottom. Fie! Fie, I am scared! [Laughter] I am so terribly scared. I said: "No". ERA, CD 7 (27) < Staryi Revel village, Omsk Oblast < woman, born in 1924 (1997).

Fear and a distrustful attitude towards the Kirgiz might be caused by various factors.

In Estonian folklore Central Asian and other nomadic peoples - the Kirgiz, the Bashkirs, the Tatars - occur in the legends about looters and dog-faced creatures. ${ }^{9}$ The texts frequently mention that they plunder, abduct and eat humans (women, children) and feed on horse meat.

The general conceptions of the Kirgiz and the Tatars were also known across Europe. These conceptions and names have merged with other religious images and form new variants in different languages; for example, the word tatar has been associated with the reminiscences of the wars waged against different Asian and Turkic peoples.

The Turkic peoples and Russians have a set of beliefs and legends about both the Kirgiz and the Tatars. In these, the Kirgiz in Siberia, for example, sometimes act as thieves, but they are interested in kidnapping mostly women and children rather than stealing a fortune. In Russian historical songs and bylinas that have been recorded in Siberia, someone held captive by the Tatars often laments about the miserable fate (Byliny 1939: 86-87, 148-149). This belief is still valid today, which is also confirmed by another Russian narrator. According to the storyteller, there was a woman in their village whose mother had been kidnapped and whose descendants were half-blood.

The Kirgiz used to be impudent. Rushed (galloped) here on their horses, grabbed the girl and took off. They have good horses, they cannot be caught. Far into the steppes? You can't get to them. (Fedorova 1984: 90) 
Legends about the Kirgiz who used to live on their lands are known also among the Turkish-speaking peoples in Tuva, Khakassia, the Altai Mountains, Yakutia, Buryatia and elsewhere. In the legends of the latter, the Kirgiz are depicted as a mighty, powerful nation, which in a way reflects the historical truth (Moldobaev 1993: 293).

In Russian folklore the Kirgiz have become a semi-mythological nation and sometimes this name involves several Turkic peoples. Alexander Panchenko, who has analysed sacrifice, cannibalism and killing of children in the Russian national religious movements of the 18 th and 19 th centuries, emphasises that these topics have had a complex and variegated history in the cultural tradition of both Russia and the whole Europe. Among other things, public consciousness uses these topics to interprete the 'alien' and 'unfamiliar' social order: often the strangers, i.e., people from another society, are presented as cannibals (Panchenko 2004: 34).

Panchenko holds that the description of an "alien" social group is constructed by the 'inversion' principle: the latter is often referred to as a system with transformed norms and therefore, in comparison to the interpreters' "own" culture, is regarded as a taboo. Material for the construction of such a reverse image is drawn from the cultural forms that give rise to an unusual feeling of anxiety and uncertainty. So the contacts of the society not only with another society, but also with another confession, so-called alien religion, are highly significant. In a way, it is like an adaptation mechanism to another culture and another nation (ibid.).

In the material under discussion, it also seems to be significant that images of kidnapping and eating of children have been attributed to the groups of another confession (Muslims), who were called inovertsy (people of a different faith) in Tsarist Russia. Also, different eating habits that have been highlighted in the descriptions of the Turkic peoples, are related to religious beliefs and cultural norms. On the one hand, alien groups are attributed behaviour regarded as a taboo or abnormal in one's own culture (kidnapping and eating children, taking people away), while on the other hand, alien religious beliefs are described as wrong (different eating habits).

A woman born in 1926 mentioned that she was terrified of the Kirgiz in her childhood. According to her, there were quite many Kazakhs or Kirgiz living in her home village, Zolotaya Niva, and Estonians had become a minority in the village formerly predominantly populated by Estonians (Kulu 1997: 207-209, 218). She considers it necessary to add that, judging by her personal experience, the Kirgiz are a fine nation. 
- But the Kirgiz are Kirgiz, I'm terrified of them. A Kirgiz once came here on horseback, I was trembling so much and was so afraid that, oh god, the Kirgiz wouldn't put me on the horse.

ERA, CD 499 (24) < Zolotaya Niva village, Omsk Oblast < woman, born in 1926 (2000).

- But they, people here, are like Gypsies. They are very nice, not thieves, not ubistva ['killers']. He would never touch another person, if you socialise with a Kirgiz, he is your best friend.

ERA, CD 499 (26) < Zolotaya Niva village, Omsk Oblast < woman, born in 1926 (2000).

The views based on religious beliefs can be transmitted only when the other nation is not sufficiently known. When an unknown nation becomes more familiar and their behaviour is understood and becomes commonplace, these conceptions (for instance, eating children) phase out. An important factor in the perceptions about a nation is their relationship with narrators, i.e., the boundaries of distance. We may say that in reality the Turkic peoples are not well known and therefore different conceptions may exist.

Aivar Jürgenson maintains that this might be a case of political correctness: in the Soviet society it was a taboo to talk about international relations negatively (Jürgenson 2002: 22). What a person really thinks is not clear: the negative and positive opinions occur side by side. However, it is plausible that for contemporary Estonians the corresponding image of the Kirgiz and Tatars may be contradictory: on the one hand, they are distant and unfamiliar people who are feared, and on the other, the ones with whom one lives side by side every day. Social and political changes have been rapid during the lifetime of the older generation. The conception of these peoples is clearly changing. Similarly, the way how Turkic peoples, as one's neighbouring peoples in general, were perceived by the parents and grandparents of today's older generation, as well as by Estonian expatriates, was also different.

\section{CONCLUSION}

Similarly to other ethnic groups and nations, the Estonians in Siberia have an ethnocentric worldview: this means that everything divergent from their culture is viewed as negative. For example, Estonians definitely view the indigenous Turkic peoples in Siberia in a negative light. For Estonians in Siberia the Turkic peoples occupy an important place in the conceptions about the Others 
and thus they have been labelled with several specific and general stereotypes. Although descriptions of another nation have not always been presented in a negative key, they still speak about a foreign people different than us. Explicit dislike for the Turkic peoples is expressed in the case of mixed marriages and multi-ethnic villages, although these peoples do not have such a role in the real assimilation process.

Oppositions are related to the nomadic lifestyle and a different faith, but also different appearance. The more frequently recurring themes in the narratives of Siberian Estonians are the eating habits, the religious practices, and the lifestyle of the other ethnic groups. Quite widely practiced is the cautionary formula told to misbehaving children: "A Kirgiz will come and take you away!" When discussing Estonian folklore about the Turkic peoples, of primary importance is cultural opposition, accompanied by religious opposition, rather than ethnic antagonism (one nation or another). People are vulnerable to the immersion of strangers, members of an alien group, into their villages and families. 'Strangers' in this case can be seen in perspective - they invade our territory and endanger the way of life and identity of the "Us"-group.

The aforementioned image of an "alien" is supported by the official institutional viewpoint. In the nationality policy of both Tsarist and Soviet Russia, minority groups were seen as being of secondary importance and "alien", and their rights to their own culture and identity were not recognised.

In reality, of course, there were no negative relationships between the ethnic groups and between individuals. Also, generally contacts were quite rare and became more frequent only as late as in the 1930s, when the establishment of collective farms brought a multiethnic population to the villages. Today, both Estonians and the Turkic peoples are endangered by assimilation. Ethnicity is not as important as previously, but this may vary by different persons and generations.

Social and political changes have been rapid during the lifetime of the older generation. Today elderly Estonians may have controversial attitudes towards the kirgised (the Kirgiz) and tatarlased (the Tatars): on the one hand, they are regarded as a menacing, distant and unfamiliar ethnic group, while on the other, they are people living side by side with Estonians day by day. As a woman from Ryzhkovo village said in 2000: "We have nothing to do with them; they live with their own kind." 


\section{ACKNOWLEDGEMENTS}

This research was supported by institutional research funding IUT (IUT22-4 and IUT2-43) of the Estonian Ministry of Education and Research.

\section{NOTES}

1 In the east, for example, in the Minusinsk Hollow in the southern part of Krasnoyarsk Krai, Estonians live side by side with the Khakas and the Tuva; in the Far East, with the Koreans and the Chinese.

2 The Estonian Folklore Archives (established in 1927) are the central folklore archives in Estonia and are affiliated with the Estonian Literary Museum. The fieldworks discussed in this article have been initiated by Anu Korb, folklorist at the Estonian Folklore Archives, whereas I have taken part in collecting on eight different occasions. The collected materials are also held in the same archives.

3 Folklore collecting situation has been studied by Risto Järv (2000), who has analysed collecting situations of folk tales in Orava village.

4 The 1920s have been regarded as the "golden age" of nationality policy in the Soviet Union. Similar to other minority groups, Siberian Estonians also had their Estonianlanguage schools, newspapers and religious life. The influence of this era is considered as one of the factors causing the strong ethnic identity of Siberian Estonians today.

5 A beverage of mare's fermented milk.

6 The percentage of Estonians in Mikhailovka is 49\%. In some Estonian villages in Siberia, Russians are called Setus.

7 According to Ilia Lotkin, the percentage of Estonians in Orava village is 40\% (Lotkin 1996: 49).

8 In 1996, the population of Tsvetnopolye village included 103 Kazakhs, 104 Estonians, 386 Russians, and 1263 Germans (in all 20 different nations) (Korovushkin 2008: 192; Jürgenson 1998: 137; Korb 2007: 26).

9 Human races different from the Caucasian race have often been regarded as dogfaced creatures, and they are notably aggressive towards baptised people with fair skin (Hiiemäe 1998: 59). In addition to the name 'the Turks', the warriors plundering the land during the Russian-Livonian, Russian-Turkish and the Great Northern War were also called paskiirid or paskirid (the Baskirs) and kirgesed (the Kirgiz). However, today this tradition has faded away in Estonia. 


\section{ARCHIVAL SOURCES}

ERA, CD - Estonian Folklore Archives, digital sound recordings on CDs (1997-2002)

ERA Foto - Estonian Folklore Archives, photographic collection

EFA - Estonian Folklore Archives, manuscripts as of 1996

RKM, Mgn. II - Estonian Folklore Archives, analog sound recordings (1953-1993)

\section{REFERENCES}

Allport, Gordon W. 1958. The Nature of Predjudice. Abridged by G. Allport. Garden City, NY: Doubleday.

Baituganov, V. 1998. Pesenno-tantseval'nyi fol'klor s. Makarovka Kyshtovskogo raiona Novosibirskoi oblasti v narodnom kalendare. [Singing and Dancing Folklore in Makarovka village, Kyshtovsky Region, Novosibirsk Oblast, in Folk Calendar.] In: I. Gemujev \& E. Fursova (eds.) Russkie Sibiri: kul'tura, obychai, obriady. Izdatel'stvo Instituta arkheologii i etnografii SO RAN, pp. 71-96. Available at http://www.sati.archaeology.nsc.ru/library/russian/russian.htm, last accessed on July 1, 2014.

Bauman, Richard 1971. Differential Identity and the Social Base of Folklore. The Journal of American Folklore, Vol. 84, No. 331, pp. 31-41. http://dx.doi.org/10.2307/539731.

Bauman, Richard \& Briggs, Charles L. 1990. Poetics and Performance as Critical Perspectives on Language and Social Life. Annual Review of Anthropology, Vol. 19, pp. 59-88. http://dx.doi.org/10.1146/annurev.an.19.100190.000423.

Byliny $1939=$ Byliny $i$ istoricheskie pesni iz Iuzhnoi Sibiri. [Bylinas and Historical Songs from Southern Siberia.] Sost. N. S. Guliaev. Novosibirsk: OGIZ.

Dal, Vladimir 1957. Poslovitsy russkogo naroda. Sbornik V. Dalia. [Proverbs of the Russian people: V. Dahl's Collection.] Moskva: Izdatel'stvo Azbuka.

Diment, Galya \& Slezkine, Yuri 1993. Introduction. In: G. Diment \& Y. Slezkine (eds.) Between Heaven and Hell: the Myth of Siberia in Russian Culture. New York: St. Martin's Press, pp. 1-6.

Douglas, Mary 2002 [1966]. Purity and Danger: An Analysis of the Concepts of Pollution and Taboo. London \& New York: Routledge.

Draitser, Emil A. 1998. Taking Penguins to the Movies: Ethnic Humor in Russia. Detroit: Wayne State University Press.

Dundes, Alan 1996. Defining Identity through Folklore. In: Folklore Matters. Knoxville: The University of Tennessee Press, pp. 1-39.

Fedorova, V. 1984. Sobiranie fol'klora v Zaural'e. [Folklore Collecting in Zauralye.] In: Russkii fol'klor, XXII. Leningrad: Nauka, pp. 85-91.

Gorenburg, Dmitry 2006. Soviet Nationalities Policy and Assimilation. In: D. Arel \& B. A. Ruble (eds.) Rebounding Identities: The Politics of Identity in Russia and Ukraine. Baltimore: The Johns Hopkins University Press, pp. 273-303.

Goryushkin, Leonid M. 1991. Migration, Settlement and the Rural Economy of Siberia, 1861-1914. In: A. Wood (ed.) The History of Siberia: From Russian Conquest to Revolution. London \& New York: Routledge, pp. 140-157. 
Grant, Bruce 1993. Siberia Hot and Cold: Reconstructing the Image of Siberian Indigenous Peoples. In: G. Diment \& Y. Slezkine (eds.) Between Heaven and Hell: The Myth of Siberia in Russian Culture. New York: St. Martin's Press, pp. 227-253.

Halikov, Nail' 2001. Traditsionnoe Khoziaistvo. [Traditional Economy.] In: R. Urazmanova \& S. Cheshko (eds.) Tatary. Moskva: Nauka, pp. 162-194.

Hiiemäe, Mall 1998. Kas koerakoonlased olid sõjaröövlid? [Were Dog-Faced Creatures Looters?] In: T. Tender (ed.) Emakeele Seltsi Aastaraamat. [The Yearbook of the Estonian Mother Tongue Society.] Vols. 35-42, 1989-1996. Tartu: Eesti Teaduste Akadeemia, pp. 52-66.

Ishakov 2001a = Iskhakov, Damir. Tatarskaia Etnicheskaia obshchnost'. [Tatar Ethnic Community.] In: R. Urazmanova \& S. Cheshko (eds.) Tatary. Moskva: Nauka, pp. 11-25.

Ishakov 2001b = Iskhakov, Damir. Tatarskoe natsional'noe dvizhenie 1980-1990-kh godov. [Tatar National Movement of the 1980s-1990s.] In: R. Urazmanova \& S. Cheshko (eds.) Tatary. Moskva: Nauka, pp. 520-539.

Järv, Risto 2000. Old Stories in Contemporary Times: A Collecting Experience in the Orava Village in Siberia. In: Folklore: Electronic Journal of Folklore, Vol. 13, pp. 37-65. doi:10.7592/FEJF2000.13.orava.

Jürgenson, Aivar 1998. Emakeele osast Siberi eestlaste etnilises identiteedis. [The Role of the Mother Tongue in the Ethnical Identity of the Siberian Estonians.] In:

A. Tuisk (ed.) Eesti kultuur võõrsil. Loode-Venemaa ja Siberi asundused. [Estonian Culture in Exile: Settlements in Northwest Russia and Siberia.] Tartu: Eesti Kirjandusmuuseum, pp. 126-142.

Jürgenson, Aivar 2002. Siberi eestlaste territoriaalsus ja identiteet. [The Identity and Territoriality of Siberian Estonians.] Tallinna Pedgoogikaülikooli humanitaarteaduste dissertatsioonid 7. Tallinn: Tallinna Pedagoogikaülikooli Kirjastus.

Jürgenson, Aivar 2008. Siber - vabaduse ja vangiahelate vahel. [Siberia: Between Freedom and Imprisonment.] Tallinn: Argo.

Jürgenson, Aivar 2011. Everlasting Desire for the Center of the World: The Creation of Homeland. An Example of Siberian Estonians. In: I. G. Rozenberga \& M. Zirnite (eds.) Oral History: Migration and Local Identities. Riga: University of Latvia, pp. 138-149. Available at http://academia.lndb.lv/xmlui/handle/123456789/10, last accessed on May 30, 2014.

Kalmre, Eda 2013. The Human Sausage Factory: A Study of Post-War Rumour in Tartu. Amsterdam \& New York: Rodopi.

Kappeler, Andreas 2001. The Russian Empire: A Multiethnic History. Harlow \& New York: Longman.

Korb, Anu 2004. On Factors Affecting Folkloristic Fieldwork: On the Example of Estonians in Siberia. In: Folklore: Electronic Journal of Folklore, Vol. 27, pp. 101-132. doi:10.7592/FEJF2004.27.korb.

Korb, Anu 2007. Siberi Eesti kogukonnad folkloristliku uurimisallikana. [Estonian Communities in Siberia as a Source for Folkloristic Research.] Dissertationes Folkloristicae Universitatis Tartuensis 8. Tartu: Tartu Ülikooli Kirjastus. Available at http://dspace.utlib.ee/dspace/bitstream/handle/10062/3421/korb_anu. pdf? sequence=1, last accessed on May 30, 2014. 
Korb, Anu 2010. Healers and Healing Skills in the Ryzhkovo Vironian Community. In: Folklore: Electronic Journal of Folklore, Vol. 45, pp. 27-46. doi:10.7592/ FEJF2010.45.korb.

Korovushkin, Dmitrii 2008. Latyshi i estontsy v Zapadnoi Sibiri: Rasselenie i chislennost'v kontse XIX - nachale XXI veka. [Latvians and Estonians in Western Siberia: Settlement and Population at the End of the 19th - Beginning of the 21st Centuries.] Novosibirsk: Izd-vo In-ta arkheologii i etnografii SO RAN. Available at http://www.balther.net/public/documents/LatEst_in_Siberia_small.pdf, last accessed on July 1, 2014.

Korovushkin, Dmitrii 2009. Chuvashiv Zapadnoi Sibiri: Rasselenie i chislennost'v kontse XIX - nachale XXI veka. [Chuvash People in Western Siberia: Settlement and Population at the End of the 19th - Beginning of the 21st Centuries.] Novosibirsk: Izd-vo In-ta arkheologii i etnografii SO RAN. Available at http://ethnography. omskreg.ru/res/page000000001266/Files/4C.pdf, last accessed on July 1, 2014.

Korusenko, Svetlana 1999. Genealogiia i etnicheskaia istoriia barabinskikh $i$ kurdakskosargatskikh Tatar. [Genealogy and Ethnic History of the Baraba and KurdakSargat Tatars.] Novosibirsk: Nauka.

Kulu, Hill 1997. Eestlaste tagasiränne 1940-1989 Lääne-Siberist pärit eestlaste näitel. [Estonian Return Migration 1940-1989: A Case of West-Siberian Estonians.] Tartu: Tartu Ülikooli Kirjastus.

Kuutma, Kristin \& Seljamaa, Elo-Hanna \& Västrik, Ergo-Hart 2012. Minority Identities and the Construction of Rights in Post-Soviet Settings. In: Folklore: Electronic Journal of Folklore, Vol. 51, pp. 49-76. doi:10.7592/FEJF2012.51.kuutmaseljamaa-vastrik.

Laineste, Liisi 2008. Post-socialist Jokes in Estonia: Continuity and Change. Dissertationes Folkloristicae Universitatis Tartuensis 12. Tartu: Tartu University Press. Available at http://dspace.utlib.ee/dspace/bitstream/handle/10062/7808/ lainesteliisi.pdf?sequence=1, last accessed on May 30, 2014.

Lotkin, Ilia 1996. Sovremennye etnicheskie protsessy u latyshei i estontsev Zapadnoi Sibiri. [Modern Ethnic Processes at Latvians and Estonians of Western Siberia.] Moskva: Institut etnologii i antropologii RAN.

Moldobaev, Imel' 1993. Ustnye rasskazy o kyrgyzakh u narodov Sibiri. [Oral Stories about the Kyrgyzakh at the People of Siberia.] In: B. Zoriktuev (ed.) Etnicheskaia istoriia narodov Iuzhnoi Sibiri i Tsentral'noi Azii. Novosibirsk: Nauka, pp. 292-296.

Must, Aadu 2012. Siber ja Eesti. Jalaraua kõlin. [Siberia and Estonia: The Rattle of Shackles.] Tartu: Tartu Ülikooli Kirjastus.

Nigol, August 1918. Eesti asundused ja asupaigad Wenemaal. [Estonian Settlements and Places of Residence in Russia.] Tartu: Postimees. Available at http://ida.aule. ee/raamatud/nigol1918_orig.pdf, last accessed on May 27, 2014.

Noyes, Dorothy 2012. The Social Base of Folklore. In: R. F. Bendix \& G. Hasan-Rokem (eds.) A Companion to Folklore. Chichester: Wiley-Blackwell, pp. 13-39. http:// dx.doi.org/10.1002/9781118379936.ch1.

Panchenko, Alexander 2004. New Religious Movements and the Study of Folklore: The Russian Case. Folklore: Electronic Journal of Folklore, Vol. 28, pp. 111-128. doi:10.7592/FEJF2004.28.movement. 
Perepis 1926 = Vsesoiuznaia perepis' naseleniia 1926 goda. [All-Union Population Census of 1926.] http://demoscope.ru/weekly/ssp/rus_nac_26.php?reg=1082, last accessed on June 2, 2014.

Perepis $2010=$ Vserossiiskaia perepis' naseleniia 2010 goda . [All-Russian Population Census of 2010.] http://www.gks.ru/free_doc/new_site/perepis2010/croc/perepis_ itogi1612.htm, last accessed on June 2, 2014.

Petersoo, Pille 2007. Reconsidering Otherness: Constructing Estonian Identity. In: Nations and Nationalism, Vol. 13, No. 1, pp. 117-133. http://dx.doi.org/10.1111/ j.1469-8129.2007.00276.x.

Slezkine, Yuri 1993. Savage Christians or Unorthodox Russians? The Missionary Dilemma in Siberia. In: G. Diment \& Y. Slezkine (eds.) Between Heaven and Hell: The Myth of Siberia in Russian Culture. New York: St. Martin's Press, pp. 15-31.

Tuisk, Astrid 1999. Siberi eestlaste kujutlused ümberkaudsetest turgi keeli rääkivatest rahvastest. [Siberian Estonian's Image of Surrounding Turkic Peoples.] In: E. Kalmre (ed.) Kuuldust-nähtust. Tänapäeva folkloorist IV. Tartu: Eesti Kirjandusmuuseum, pp. 87-107. Available at http://www.folklore.ee/pubte/ kuuldust/, last accessed on June 2, 2014.

Valeev, Foat \& Tomilov, Nikolai 1996. Tatary Zapadnoi Sibiri: Istoriia i kul'tura. [Tatars of Western Siberia: History and Culture.] Novosibirsk: Nauka.

Viikberg, Jüri 2010. Eestlased ja eesti keel Venemaal. [Estonians and the Estonian Language in Russia.] In: K. Praakli \& J. Viikberg (comps. \& eds.) Eestlased ja eesti keel välismaal. [Estonians and the Estonian Language Abroad.] Tallinn: Eesti Keele Sihtasutus, pp. 517-550. Available at http://www.eki.ee/books/eekv/ EEKV.pdf, last accessed on June 2, 2014. 


\title{
THE INTERRELATIONSHIP OF RELIGION AND MAGIC IN THE EXPERIENCE OF LATVIANS IN TIMOFEYEVKA, SIBERIA
}

\author{
Aigars Lielbardis
}

\begin{abstract}
Groups of texts about seasonal celebrations, family customs and charmers are examined in this article in order to reveal the interrelationship of magic and religion in Latvian traditional culture in Timofeyevka. The recollections and knowledge of informants, recorded in 2004 and 2006, during fieldwork in Timofeyevka, have been supplemented with examples published in the 19th and 20 th centuries, as well as recently documented examples of Latvian folklore in Latvia.

The entire year of seasonal celebrations, which have become closely associated with the Catholic calendar - Christmas, Epiphany, Easter, Pentecost, Midsummer, and the remembrance of the dead in the autumn - has been examined. Annual festivities celebrated in the Latvian community have merged with Slavic festivals, for example, Easter, Pentecost and Midsummer traditions. In the recollections of family customs descriptions of funeral customs dominate over christenings and weddings. Notions of the supernatural are revealed in the stories of personal experience about healing, as well as in belief legends, which tell about the unusual ability of a person to transform into an animal or object. The experiences of the Latvian community of Timofeyevka concerning religion (official religion) and magic (unofficial religion) cannot be differentiated, because they represent a unified conceptual system in which one adds to the other.

The rich traditional cultural heritage in Timofeyevka has been preserved due to the location of the village far away from large cities and main roads, and also due to the Latvian community's large population numbers in the past.
\end{abstract}

Keywords: charming tradition, family customs, Latvians, magic, religion, seasonal celebrations, Siberia

\section{HISTORY AND PROBLEMS OF RESEARCH}

The study of Siberian Latvians was undertaken in the first half of the 20th century by Augusts Melnalksnis (1933, 1938), Vilberts Krasnais (1938) and Kārlis Šķilters (1928). Although during the Soviet era Latvians were forbidden to express any interest in Siberia, Ingvars Leitis, Uldis Briedis, Vaira Strautniece and Andris Slapiňš visited Latvian villages in Siberia in the 1970s, documenting evidence of Latvian culture and language. A study of another 
Latvian village, Nizhnaia (Lower) Bulanka (Lat. Lejas Bulāna), was published under the guidance of Vaira Strautniece in 1995. In 1996 and 1997, Roberts Kinlis conducted fieldwork in Bobrovka (Lat. Augšbebri) (Ḳilis 2002), which, like many other Latvian villages, was established at the end of the 19th century. In 2000, historian Jāzeps Brolišs published a historical-philosophical essay about the fates of Latgalians in Siberia (Brolišs 2000). Lidija Leikuma and Aleksejs Andronovs have been studying the language and history of Siberian Latgalians since 2004. Mikhail Kolotkins's study of Latgalians in Siberia was republished in 2012 (Kolotkin 2012). Still another Russian scholar, Ilia Lotkin, has also focused his interest on the ethnic processes of Latvians and Estonians in northern Siberia (Lotkin 1996). A number of these publications mention Timofeyevka village, although broader and more detailed information about this village was gained during the 2004 and 2006 fieldwork, which was undertaken by collaborating specialists from various fields - folkloristics, linguistics, ethnomusicology and history. A collection of academic articles about Latvians in Timofeyevka, which was based on the materials collected during this fieldwork and entitled Latvians about Latvians: Siberia. Timofeyevka, compiled by Aigars Lielbārdis, was published in 2011.

Today, Timofeyevka is a small village in the Vengerovsky district in Siberia, which is situated almost 500 kilometres from Novosibirsk, the regional centre. The village was founded in 1895 by emigrants from Latgale (the eastern part of today's Latvia), which belonged to the Vitebsk Gubernia of the Russian Empire in the 19th century. In the second half of the 19th century, Latvian emigration was stimulated mainly by political and economic factors - small farms, shortage of financial resources and land, as well as social and legal inequality. Latvian families, sometimes even whole villages, emigrated not only to other gubernias in Tsarist Russia, but also to other continents like Australia and North and South America. According to calculations made by Vilberts Krasnais, more than 200,000 Latvians, including Latgalians ${ }^{1}$, lived in the contemporary territories of Russia, Ukraine and Belarus, that is, in the Soviet Union in the 1920s (Krasnais 1938: 130).

In the early 20th century, Timofeyevka had already developed into a significant Latgalian centre in central Siberia. It appears that the villagers took about 10-15 years to adjust to their new living conditions and reach material prosperity: this assumption is based on the observations made by a Catholic priest Konstantīns Skrinda in the summer of 1909, when he and Archbishop Jānis Ceplaks travelled around Siberian Catholic communities. At that time, Timofeyevka already had its own dairy, church, 114 farmsteads and 540 inhabitants (Skrinda 1910). Later on, the village also boasted a mill and a butter factory. In terms of its population numbers, it was one of the largest Latvian 
emigrant centres in Siberia. Almost a hundred years later, in 2004, Timofeyevka had 170 inhabitants and only 66 of them identified themselves as being Latvian, and had good skills in the spoken Latvian dialect used in Timofeyevka (Mežs 2011: 73-74).

There was a church and a place for open religious worship in Timofeyevka until the late 1920s and early 1930s. As Soviet anti-religious campaigns became more active, an atheist group was established in 1928 (Skobajs 1928), and in 1933 a decision was taken to transform Timofeyevka church into a community hall - a club (Jurevičs \& Meikšans 1933). According to the recollections of villagers, the interior of the church was damaged and religious items were thrown into the nearby River Tartas. Nevertheless, people managed to rescue some of these objects and still keep them in their houses today, the broken details of crucifixes having been tied up with a ribbon.

Catholic prayer books and rosaries inherited from parents and grandparents are similarly treasured. Some women from the older generation still cross themselves after meals, saying thanks to God for the meal and also before lying down, to be safe while sleeping. This kind of religious piety is characteristic

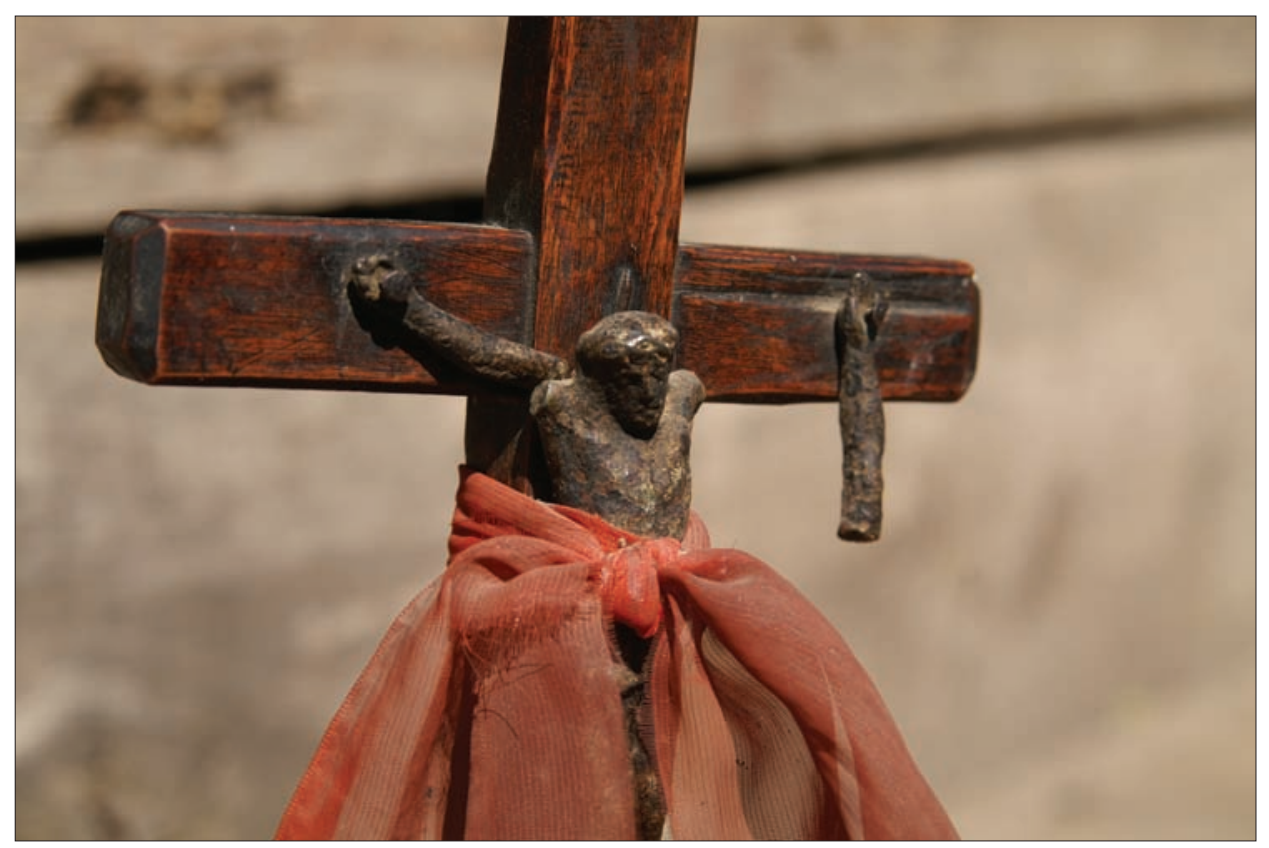

Figure 1. Broken crucifix at the home of Beña Vilcāne. Photograph by Janinna Kursìte 2006. 
of Catholicism generally, and was once taught and practiced within Latvian families in Timofeyevka, mostly due to the inner needs of individuals. Today, when both religious expression and the Latvian language are disappearing from active daily use, a strong link between language and denominational belonging still exists in the perceptions of the older generation in the Latvian community. At the turn of the 20th century, when national identity was strengthening in Latvia, people in Latgale often self-identified as Catholics. In Timofeyevka in 2004, an informant, Vera Kalugina, still expressed her doubt: "I am Latgalian... That is, a Catholic. Our Latvians are considered to be Catholics, not Latvians. Latvians speak some other language."

At the same time many respondents pointed out that there was no difference between Latvians and Latgalians. However, language and denominational belonging were listed as characteristics that distinguished Latvians from the Slavs and Tatars who also lived in the village.

Groups of texts about seasonal celebrations, family customs, belief legends and stories of personal experience, which characterised the activities of sorcerers and charmers, were used to discover the interrelation of magic and religion in the traditional culture of the Latvians of Timofeyevka. These groups of texts are independent, although they add to each other, and are closely intertwined in the mind of the user. The timing and content of seasonal celebrations are based on the passing down of societal customs, which include changes and influences between generations in farming management, as well as on isolation and detachment from the keepers of tradition in Latvia. Notions of the existence of the supernatural are revealed in the stories of personal experience in curing diseases and in belief legends that tell about the unusual ability to transform into an animal or object. In turn, family customs reveal the lifestyle and assumptions of the village community, which have occasionally gained new characteristics peculiar to Timofeyevka.

In his analysis of displays of magic, Latvian folklorist Kārlis Straubergs indicates that magic can be classified as either active (action, attempts to influence) or passive (knowledge of causal relationships in human life and nature) (Straubergs 1935-1936: 25147), and that "magic uses two main devices: words and action" (Straubergs 1923: 807). These devices are at the basis of both magic, which is commonly associated with folklore, and religious practice. Marcel Mauss has observed that magic, or a magical rite, is any rite that does not play a part in organised cults: it is private, secret, mysterious, and approaches the limit of a prohibited rite (Mauss 2006 [1972]: 30). Belief in supernatural forces, the knowledge of and attempt to influence them, are the grounds on which Catholicism and magic intersect and complement one another, and this is what has created the originality of tradition in Timofeyevka. 
In this article, recollections and knowledge recorded during interviews with informants in 2004 and 2006, during fieldwork in Timofeyevka, have been supplemented with published examples of Latvian folklore, in this way broadening the contextual information and offering comparative material.

\section{SEASONAL CELEBRATIONS}

These celebrations include annual events which, defined by the traditional way of life, have grown together with the Catholic Liturgical Calendar in Timofeyevka and can be evaluated not only in the context of contemporary Latgale, but also in the general Latvian context. Estonian folklorist Kristi Salve has noted that seasonal celebrations have three functions: (1) timekeeping, (2) magical, and (3) entertaining (Salve 1994: 160). Additionally, Latvian linguist and folklorist Beatrise Reidzāne has observed that the content of seasonal celebrations is based mainly on the same principles during both of the major celebrations of the year (Christmas and Midsummer Eve) and less important seasonal celebrations: (1) ritual activities and ritual prohibitions, (2) sacred meals, (3) fortune-telling and predicting (Reidzāne 2008: 233). Therefore, the presence of both religion and magic can be observed in the activities and interpretation of seasonal celebrations.

In Timofeyevka, seasonal celebrations in winter, spring and summer can be observed in the context of Latvia, while events in the autumn period are characteristic only of Latgale. In the autumn, a significant role is attributed to the honouring of the dead with psalm singing, or the Office of the Dead' ${ }^{2}$.

In earlier times, fir trees were decorated during Christmas in Timofeyevka, the priest visited people in their homes, and there was altar bread, decorated with pictures of Jesus. Both in Latgale and Timofeyevka, altar bread wafers were called kaladas, "holy bread that is made from wheat flour and is very thin - similar to a sheet of paper. The kaladas have various Christmas pictures. Before eating them you had to fast" (Čudare-Erina 2005: 144-145).

It was common for Latvians to go mumming at Christmas. Folklorist Jānis Alberts Jansons has observed that the word čigāni (Gypsies) designates those who participate in mummers' processions in all Latvian regions (Jansons 2010: 135). Informant Vera Loča states that, in earlier times, people in Timofeyevka went mumming at Christmas. Wherever they went, they were given something to drink and were offered a place at the table. They dressed up as old ladies and smeared themselves. Typical mummers' costumes in Timofeyevka were: a bear (a fur coat turned inside out), an old lady, and a devil (smeared in soot). When going mumming, special bags were taken along in which to pack the 
received treats. These kinds of bags were also used in mummer processions in Latgale both at the turn of the 20th century (Čudare-Erina 2005: 152), and in the late 20th century.

On Christmas Eve in Timofeyevka, just like the night before Easter, pious women came together, prayed to the Lord and sang religious songs. This type of night spent in prayers is called a vigil amongst Catholics. In the Soviet era, religious women held vigils secretly. The day before Christmas was called the $K \bar{u} c \check{a} a$ Day. The title is derived from the word $k \bar{u} \breve{c} a-$ a food that is made of barley, and is typically eaten during the winter solstice. The Küča Eve is known to Latvians, Lithuanians, Russians and Belarusians, both in terms of the name and similar functions (Līdeks 1991: 8), which indicates a wide distribution of the tradition and presumably also a shared heritage.

The Latvians of Timofeyevka were also familiar with fortune-telling at Christmas and during New Year celebrations. Informant Vera Loča recalls:

In earlier times, felt boots were tossed over the gate before Christmas and New Year. The direction in which they fell showed you where you would be married. They also went to the river for water. If you didn't meet anyone when coming back and you didn't hear anyone swearing, then you would get a good husband. But if you met someone who talked loudly or yelled when you were coming back from the river, then you would have a bad husband. If the person asked for a drink, then your husband would be a drunkard.

Fortune-telling by tossing footwear over a fence was also a familiar practice in Latvia (Līdeks 1991: 29), only the shoes that were thrown in Latvia were replaced by more wintery footwear in Timofeyevka - by felt boots.

Christmas is followed by Epiphany (Zvaigznes diena or Kreščine). On this day, crosses are drawn on the doors and doorposts. Informant Vala Savenko comments:

We always draw crosses on January 6. And we write 'Gaspar', 'Melchior' and 'Balthazar' on the doors. We cross the doors, windows, everything. We cross outdoors. Everywhere. The cows, calves, horses too-everything. So that everything goes well, so that no one gets sick. If not - they can get sick.

Epiphany is followed by Candlemas, Sveču diena or Gromnīca. In Latgale, candles are still blessed on this day. Vala Savenko tells us: "If the rooster has already been able to have a drink on this day, then it will be a bountiful year". An identical belief has been recorded in Riga: "If on Candlemas the rooster can have a drink under the roof, then it will be a bountiful year" (Šmits 1940-1941: 298040). 


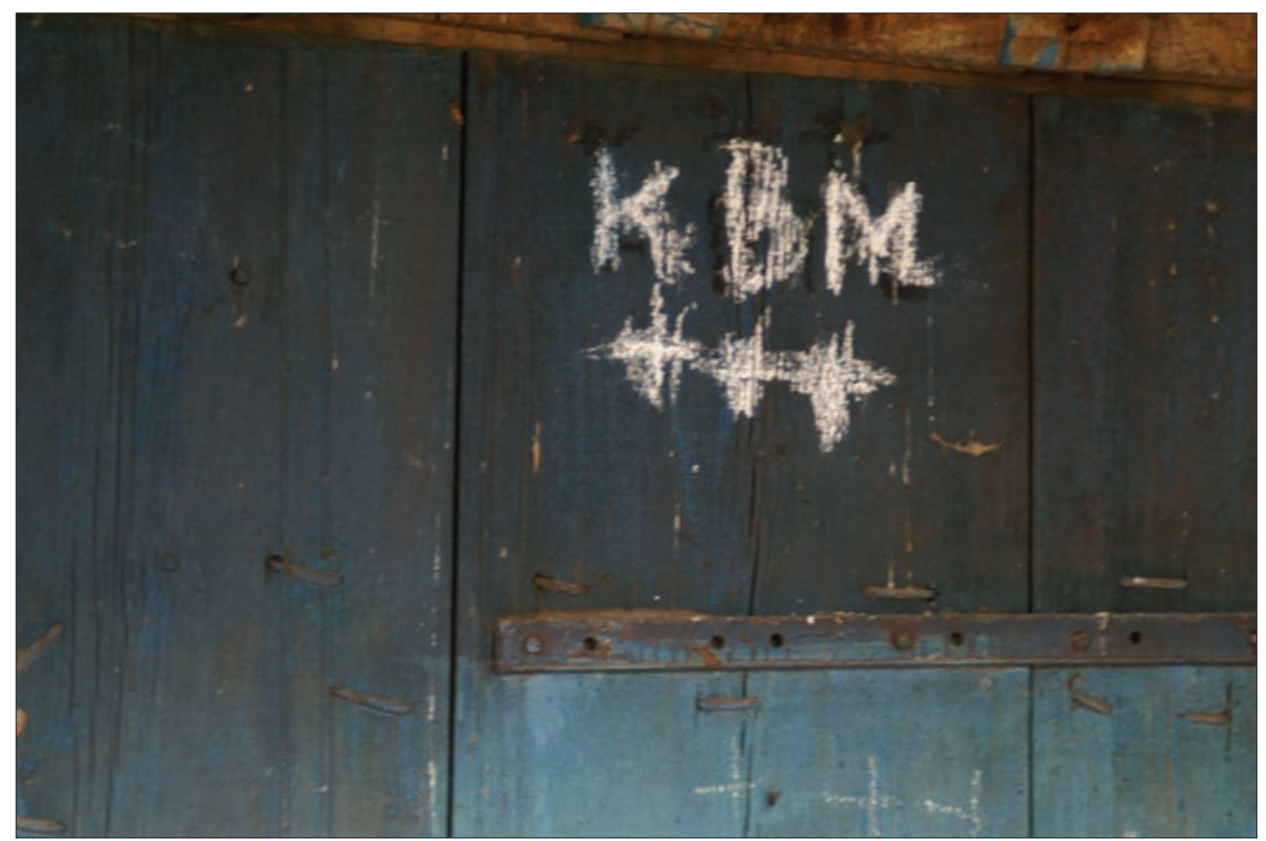

Figure 2. Crosses on the doors in Timofeyevka. Photograph by Janīna Kursìte 2006.

Candlemas is followed by Shrovetide (Aizgaveñni or Metenis), which is observed in Timofeyevka only as an activity of the past, by going horse riding and burning straw and hay on bonfires. Burning straw at Shrovetide and riding horses is also known to have been practiced all over Latvia (Līdeks 1991: 120-124). In Timofeyevka, the ancient name used in Latgale for this day, Aigaven, ni, has been preserved, alongside the Slavic Maslenica. This was the day before the beginning of Lent, or Gavēnis. Meat and fatty foods were not eaten during Lent.

Easter is one of the most richly described annual celebrations, because it continues to be celebrated in Timofeyevka today: eggs are coloured by boiling them in onion skins, and swings are hung. Children go from house to house. Entering each house, they say "Christ is risen!" three times, which must be answered with "Indeed he is risen!" The children are given pastries, sweets, or eggs. The custom of saying "Christ is risen!" in Russian has come from the Slavs, who gradually began moving into the village after the Second World War. In earlier times adults went from house to house and played egg tapping, and made swings on the bank of the River Tartas. 
In former times, and today as well, those of the Catholic faith spend the night before Easter and other celebrations at church (Čudare-Erina 2005: 163). During the Soviet period, when Timofeyevka did not have a church, these meetings were held at the home of one of the religious women. This was described by informant Gela Neminska, one of Timofeyevka's most prominent experts and singers of Catholic songs. Religious identity that is inherited and instilled from previous generations has found shelter in various religious cult objects. Vera Loča still treasures a prayer book and a rosary brought from Latvia, wrapped in a handkerchief. A small crucifix has been preserved from Timofeyevka church. Pussy willow and altar bread that have been blessed were brought for her from Novosibirsk. Vera Loča tells about how everyone in the household was symbolically 'flogged' with pussy willow on the morning of Palm Sunday, after which the branches were taken to church to be blessed. On Palm Sunday, whilst flogging, one recites:

Vierbu, vierbu!

Vierba syta, na es sytu.

Veseleiba vydā,

Slimeiba uorā!
Pussy willow, pussy willow!

The pussy willow hit, I didn't hit.

Health in the middle,

Sickness out!

Today no one flogs with pussy willow anymore. Pussy willow branches blessed on Palm Sunday were sometimes used to smoke out the place where the deceased had been laid in the home. The grave was also smoked with the pussy willow before the coffin was lowered. Blessed pussy willow was also given to domestic animals.

Pentecost (Vasarassvettki) in Timofeyevka is celebrated in the seventh week after Easter. It is the only time of the year when the inhabitants of Timofeyevka go to the cemetery to remember the dead. This is also an opportunity to meet relatives and the descendants of villagers whose family members are buried in the cemetery. Prayers are said, and food and glasses of vodka are placed on the graves when remembering the dead. The villagers themselves, and their guests, sit in a field by the cemetery and remember the dead while partaking in a meal. Pentecost, like Easter, has intertwined with the corresponding Slavic celebrations of Semik and Troica. During this time the Slavs remember the parents who have passed away (Fursova 2003: 7). Parallels can be seen between this tradition and Latvian cemetery celebrations, except for the fact that today the meal is not placed on the graves in Latvia. However, in the late 19th century, feasting in the cemetery was practiced in Latgale too: "[during the funeral] the family of the deceased treat the mourners by the graveside with beer, bread and cheese" (Ulanowska 1891: 209). The decoration of the house with 
birch boughs during Pentecost is typical both for Latvians (Šmits 1940-1941: 19606) and the people of Timofeyevka, and also the Slavs of the surrounding area (Fursova 2003: 9). In Latgale at Pentecost, shepherds decorated cows with birch branches and floral wreaths (Čudare-Erina 2005: 168). This was also practiced in Timofeyevka, and the shepherd was given an egg or a glass of vodka as a reward.

Although the older generation in Timofeyevka celebrates the summer solstice (Jāna diena or Jāñi) on June 24, it is celebrated in the village on July 6 as well. Similar to Pentecost, cows are also decorated on this day. Informants Vera Kalugina and Beņa Vilcāne recall that at Jāṇi it was customary to light bonfires, and to walk around the village, singing. People were given pastries and eggs for their singing. Cheese was also made, wreaths were plaited from wildflowers and beer was brewed at Jāni.

Fortunes were told on the summer solstice, as well as at Christmas, particularly amongst young women. Informant Zina Ivule remembers that they used to send wreaths down the river and watch where they floated: their future suitor was supposed to come from that direction. Fortune-telling with wreaths was also common in Latvia (Lìdeks 1991: 61).

Water held special meaning at Jāni : washing in the dew or in spring water, or taking horses for a swim at night helped to attain what was wished for beauty, health and success. Zina Ivule recalls:

How they splashed each other with water then! The minute you started splashing, the rain would come. Perhaps this celebration is from God. There's no rain, but then you splash, and a rain cloud starts to form. Even the adults would splash around. You splashed, and the rain always came. If there is no rain, then there will be no hay, no bread.

Splashing of water on this day was also known in Latvia (Jansons 1937: 7), although it was not very widely practiced. The influence of the Slavic surroundings can be observed here (Fursova 2003: 55). Some informants have replaced the title of Jāni with the Slavic Ivan Kupala. The night before Jāni is an active time for sorcerers and witches of both the Slavs and Latvians. In the region around Timofeyevka it was common for young people to gather together, search for witches and try to drive them away or do something bad to them. This tradition was widely practised in the Slavic villages near Timofeyevka (Fursova 2003: 62-63). Today this practice has transformed into entertainment for young people, with the aim of playing tricks on other villagers, for example, stealing their carts, wrecking their wood piles, etc. This kind of activity can also be observed in other Latvian villages in Siberia, for example, in Sukhonoi (Sukinava) (Lielbārdis 2007: 172). 
Latvian seasonal celebrations in the autumn are associated with the completion of farmwork and preparations for the winter. This is also a time of remembering the dead, or velu laiks (souls' time). In Timofeyevka, as also in Latgale, special events with psalm singing are organised to remember the dead - the Office of the Dead. The time for the commemoration of the dead is traditionally from Michaelmas (September 29) until Martinmas (November 10), but in some places it ends on All Souls' Day, November 2. The psalm singing tradition, established by Jesuit missionaries in the late 18th century, has been preserved in Timofeyevka as well as in Latgale (Lielbārdis \& Boiko 2012).

\section{FAMILY CUSTOMS}

There is a typical dominance of funeral traditions over wedding and christening customs in the recollections of the Latvians of Timofeyevka. Some informants mentioned that children would be christened by older women when there was no longer a priest in the village. The items brought to a christening included a bottle of alcohol and pastries, as well as clothes, diapers, and soap for gifts.

Wedding traditions were not emphasised either, justifying this by shortages of food and other products or the complicated post-war conditions. When attending a wedding, people took along a bottle of alcohol, as well as some meat, which was delivered a day or two beforehand. Beer was brewed for weddings. Zina Ivule tells us:

Beer was brewed, people celebrated. At weddings there was such singing! The bride was the subject of many sad songs, until she began to cry loudlyit was a valley of tears! During the wedding, horses were decorated, the shaft bow was wrapped in a beautiful towel and bells were attached.

The crying mentioned was brought about by special and purposeful singing to make the bride cry, which was an essential part of weddings in Latgale (Tihovskis 1993: 61).

Detailed information about funeral traditions in Timofeyevka is available in comparison. When a person dies, they are first washed with warm water and soap. The water is poured out at the gate by the northern (empty) corner, where no one walks, in order to protect one from illness or a malady, which can rise from the deceased. This cluster of beliefs was common throughout Latvia (Šmits 1940-1941: 1269-1272). After washing, the corpse is placed in another building, then carried to the main dwelling, where two chairs are placed, with boards on them, which are covered, and then the coffin is placed on top. The deceased is dressed in clean, usually dark clothes, with slippers on the feet. 
Women gather to say prayers, sing hymns and perform the Office of the Dead before the funeral and also on the day of the funeral. In Latgale, women also gather by the deceased in the evening, light a candle and sing songs, psalms and litanies (Ulanowska 1891: 208). As mentioned above, psalm singing is still encountered in Latgale today. In Latgale as well as in Timofeyevka, it is usually the women who specially practice this form of singing that are invited.

On the day of the funeral, the deceased is placed in the middle of the room. It is customary for the funeral to be held on the third day. The deceased is transported to the cemetery around $1 \mathrm{pm}$ or $1.30 \mathrm{pm}$, i.e., after lunch. Before transportation, the coffin is placed at the gates of the house for a short while, to bid farewell to the deceased. Earlier the coffin was transported by horse and cart, but today cars are used. There used to be a large crucifix at the edge of the village, where the funeral procession stopped for a moment. A wooden cross, $m \bar{u} c e n a$, was carried at the head of the funeral procession, followed by funeral wreaths. A man led the decorated horse by the bridle. A towel or a pair of mittens was hung on the mücena, which was given as a gift to the one carrying the cross. The grave diggers and coffin makers were given towels, while the woman who baked pastries was given a scarf. The coffin was carried behind the cross and wreaths, and after them came the mourners. In earlier times, hymns were sung at the cemetery. The lid of the coffin was opened at the cemetery, and later closed with two long nails. Informant Valentīna Bule jokes: "They hammer in big nails. After that, even if you want to get out, you can't."

Before the coffin was lowered, the grave was blessed: a page was ripped out of a prayer book and used to smoke out the grave. The smoking of the grave with blessed herbs before the deceased was lowered was also practiced in Latgale in the second half of the 19th century (Ulanowska 1891: 2009). As mentioned above, Vera Loča called the pussy willows that had been blessed in church on Palm Sunday blessed herbs. It is probable that the practice of smoking out the grave with the pages of a prayer book was a later development, which took place when it was no longer possible to bless pussy willows in church, that is, after the church in Timofeyevka was converted into a community hall.

In Timofeyevka, it is believed that if you meet someone on the road close to the village when transporting the deceased to the cemetery, there will be another death in the village soon, whereas if a person is met far from the village, death is further away. On returning from the cemetery, the mourners are given a meal. First, the women sit at the table, then the men, because men are the first to go to the sauna. The last ones to sit at the table are children. In earlier times, prayers were said before the meal, but this no longer happens.

A spiritual connection with the dead is still maintained long after the funeral, because memorial events are organised on the 9 th and 40 th day after the 


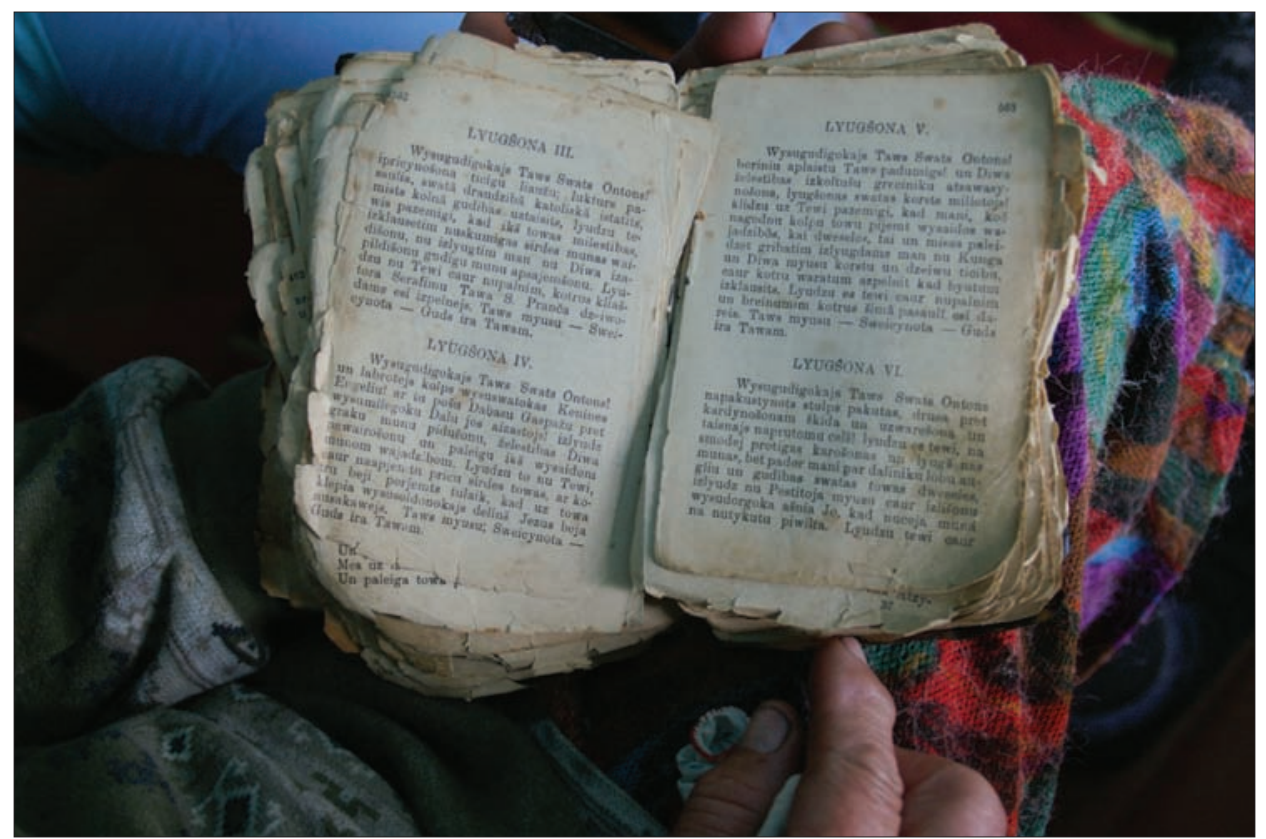

Figure 3. Zina Ivule's book of prayers and songs used for performing the Office of the Dead and for grave smoking. Photograph by Janina Kursìte 2006.

funeral. In earlier times, the Office of the Dead was performed on these days. Remembering the dead at the cemetery takes place during Pentecost, and they are also remembered at homes on the souls' day in the autumn.

The dead can communicate with the living also in dreams. For example, Gela Neminska tells us that if a dead relative appears in a dream, then someone from the family has to give a treat to the person who had the dream. Informant Viktoria Ruduša explains: if you have to give something to the deceased in a dream, then there will be a loss at home, or if the deceased appears in a dream, then one must pray for them as well, or one must feed the poor. If the deceased asks to be lifted out of the grave, then you must also pray for them. Zina Ivule also relates that if she sees someone dead in a dream, she says a prayer for the person. In Latgale today, if a dead person appears in a dream, it is interpreted as the deceased's need for something. Latvian ethnomusicologist Mārtin̄š Boiko, studying stories of meeting the dead in dreams, calls them request dreams (Boiko 2002: 119). These kinds of dreams are often the reason for the performance of the Office of the Dead at the home of the deceased. 
Sometimes dreams serve as a prediction of death. For example, Val,a Savenko tells us that if you dream of sprouted potatoes with small green leaves, someone will soon die. Dreaming of ploughing the garden is another bad omen - someone is going to die.

\section{CHARMING AND SORCERY}

Belief legends and stories of personal experience about charming, healing and sorcery in Timofeyevka fit into the Latgalian context, and that of Latvian folklore generally. It is supposed that the terms kolduns, čaraunīks (sorcerer) and varažot (to predict) as names for those who undertake various magical activities, are part of the inheritance brought from Latgale to Timofeyevka by the first settlers. Words of Latvian origin, which describe similar phenomena in Latvian folklore, are also used, although they have partly lost their meaning. For example, in Timofeyevka the word ragana (witch) is largely understood as a swear word.

In the village, healers who treated ailments and also sorcerers or witches (kolduni, čaraunīki) were usually women who had inherited their knowledge from previous generations. In earlier times, there were also midwives who attended births in Timofeyevka. Certain afflictions were well-known and regularly healed: erysipelas, toothaches and other pains, harm caused by the evil eye, dog and snake bites, hernias, broken bones and dislocations, children colic and colic in livestock. Healing methods included squashing and nipping (colic), tying wool (joint sprains), stroking (swelling), setting of dislocations, saying charms on water or spreadable healing substances. It was not possible to record the incantations during fieldwork, although it is known that hymns and the Lord's Prayer were used in Timofeyevka in the charms function. In 2006, there were two cartomancers in the village - Vera Ruduša and Vala Savenko. In turn, Galina Abaturina and Valentīna Jureviča, both Russians, worked as healers.

Healing is spoken about in the past tense, as there are no longer any Latvian charmers that can help others in the village. Informant Marija Vilcāne says:

There were these old women here. They could utter words to banish the pain. I had a broken arm. She uttered words, treated me, massaged me. She was called Vilku Gela. My husband's real aunt. She could say words when a snake had bitten you. She could charm a pain so that it wouldn't swell. It helped, it really helped. She spoke and stroked. She spoke the Latgalian God's songs. The songs were quite old. She whispered, spoke. Our father, who art in heaven... There were all sorts of words. 
Informant Vera Loča tells us that a snake bite can be treated both with words and without them - by squeezing the venom from the bite, scorching it, and applying sour milk. She treated her husband Jānis in this way. Another charmer had treated a snake bite by tracing around the bite with a special coin - a kopeck.

Snake bites in Siberian conditions were supposedly common and bites were only treated by older women. Each of the village charmers mentioned had treated a snake bite. Erysipelas, which was brought on by taking fright, was also quite common. Taking fright could also be a reason for a sickness called nobillis (affright) in Latvian, which was treated by pouring water over the patient in front of the stove. Colic ( $g r i \check{z} a$ ) could be healed with incantations. Small children usually suffered from colic. Informant Nina Kukule pointed out that you needed teeth with which the colic could be nipped. Nipping or pressing with fingers are methods that can be used to destroy other sickness - also colic, which often infects domestic animals.

Healing methods included soap with which corpses had been washed. If your hands hurt, or you had abscesses, then you washed your hands with it. The soap was also useful if your husband fought at home. Then you had to secretly give him this soap to wash his hands. Treatment with this kind of soap or other objects belonging to the world of the dead (a splinter from a cross, sand from a grave or a bone found in the cemetery) is a widely known healing method in Latvian folk medicine: the pain is symbolically transferred to the world of the dead.

During an interview, Valentīna Bule had a piece of white yarn tied around her arm, which she explained as follows:

My arm swelled up. It hurts. The bone, here. See, I tied this around, so that it would help the pain. It is said that the last one to be born in the house, the youngest, needs to tie it around. Now there's nothing. It seems that it no longer hurts.

It is best if the yarn is woollen, ideally of light colour and made of sheep's wool.

Considering the fact that there is no medical institution in Timofeyevka or in the vicinity - or that there has not been one previously - it is understandable that the villagers often deal with breaks and dislocations on their own. Marija Vilcāne told us about her mother-in-law, Domuse Vilcāne, who healed toothaches, and could also set dislocations. The words for healing were taken over from her by a Russian, Gaḷina Abaturina. Marija Vilcāne had visited her to treat a dog bite:

She can speak Latvian. I was in pain - a dog had bitten me. It really hurt. Everything was red, like erysipelas. I visited her. She uttered some words, and I spread something [given by healer Domuse] on it, and it was gone. 
As the author of this article was not successful in finding out the incantations used for healing, it is unknown whether the prayers and hymns used in incantations constituted just a part of them, or whether they made up the entirety of the charms. The Latvian tradition of charms encompasses both options: the text of the incantation may comprise only prayers, a bible text, or a fragment of a song; or the Lord's Prayer or invocation of the Holy Trinity may be added at the end of the charm.

In Timofeyevka, cartomancy (divination/fortune-telling with playing cards) is called varažošona. As linguist Jānis Zēvers points out, this word stems from Polish, with the definition 'to conjure' appearing in the catechism Mocieyba katoliszka published in Latgalian in 1775 (Zēvers 1925: 603). Cartomancy has two names in the language of the local villagers: varažot and godot. In 2006, there were two cartomancers in the village.

Sorcerers and sorcery in Timofeyevka are called kalduns and kaldavot, which means "to conjure, to do evil". Valentīna Bule tells us:

Sorcerers cast spells. Sometimes they cast spells so that a person becomes angry with another, and verbally abuses them. And one can cast a spell in anger. A cow's milk can also be made to dry up. Livestock can also die. For whatever you want, a spell can be cast. There was a woman here who cast spells. She died. It is said that sorcerers die a painful death. When she was dying, they had to take the ceiling out of the room.

The custom of taking out the ceiling over the bed of the dying sorcerer is common in Latgale as well (Lielbārdis 2008: 194-195). There are two cases in Latvian beliefs when sorcerers die, suffering seriously: 1) if they have caused harm to others, and 2) if they did not pass their knowledge to others. The taking out of the ceiling helps the soul to leave the body and is arranged only in cases of a sorcerer's death.

The word čaraunitks is also used with the same meaning. Informant Nina Kukule tells us: "A čaraunīks is the same thing. Someone who casts spells. Who casts spells to make people sick. They do evil things." Nina Kukule tells about a witch who was not able to die, and this is why the ceiling was taken from her room and a stake of aspen was poked into the ground next to the cross on her grave, with its branches facing downwards. Nina Kukule also told about sorcerers who were able to transform themselves into a pig or a cart wheel:

I don't know, perhaps we were lied to and we are passing on the lie. Some people were sorcerers. A pair of young people were walking along the road. A pig followed them everywhere. They had to keep running away. Some brave people got together and shot the pig in the ear. In the morning the neighbours came to visit and asked: "Where is your mother?" - "She's 
sleeping," they answered. - "What's wrong with her?" - "She doesn't feel well, she's sick. Her head is aching; it's wrapped in this here cloth. She's sleeping." See, how the lads shot her in the ear!

A similar story is told about a cart wheel. This kind of story about a sorcerer's power to transform into a wheel or a pig is also familiar in the regions close to Timofeyevka, except that a witch is mentioned in these stories (Fursova 2003: 62). However, this similarity does not necessarily indicate a direct link with Latvian folklore, considering that this Siberian region is inhabited mainly by the descendants of immigrants from the western provinces of the Russian empire, and not just Latvians.

Stories about people with the evil eye are also encountered in Timofeyevka. Latvian beliefs suggest that people or livestock can be harmed by the evil eye (nobrīnit) by complimenting them: 'You should never say: 'They are so beautiful!' about calves, or about flowers or crops. You can put a curse on them" (Šmits 1940-1941: 21854). The experience of Nina Kukule affirms the presence of this assumption in Timofeyevka as well: "The evil eye can put a curse on you. When I was little, I often had the evil eye cast on me." In the informant's youth, she had been laying tables for a wake, when her mother-in-law had seen her and said: "Look how strong you are, you can do everything!" And then she became sick. Her mother-in-law had said: "I hate Nina, I cast an evil eye on her!" She brought a lady who said an incantation for Nina and washed her. The informant Vala Savenko explained that people who have the evil eye are those people who, as babies, had already been weaned from the breast, but began breastfeeding again some time later. In Latgale these children were called apziejdiets (Ulanowska 1891: 207; Muktupāvela 2006: 82-92).

\section{CONCLUSIONS}

Returning to the relationship between magic and religion, as was mentioned previously, according to Marcel Mauss (2006 [1972]: 30), magic or magical activities are private, secret, mystical, and forbidden actions, which are not part of officially recognised cult practice. In this case, the term magic should be understood as wrong, actions that stand in opposition to the tenets of Catholicism. But in the case of Timofeyevka, it is more problematic to share the position of representatives of the Catholic Church. The common view of society was different because there had been no priests as the church had been destroyed in the early childhood of most informants. Therefore, a dialogue between the Church and Timofeyevka's society had not existed in the past 70 years. Despite 
this, the presence of Catholic customs is notable in the worldview of the older generation. For example, when going to bed, Valia Savenko crosses the corners of the room, so that nothing bad would happen while she is asleep, and says the Lord's Prayer. She also crosses the doors on Epiphany to protect her livestock. In turn, the healing of people and livestock with charms, hymns, or prayers is not approved by the representatives of the Catholic Church in Latvia, but the practice still exists.

According to the classifications suggested by Kārlis Straubergs, magic involves the activities of healers, sorcerers and cartomancers, both in real practice and in beliefs and stories of personal experience. With respect to today's Latvia, magic would also include the actions that were performed in Timofeyevka to conjure rain, because such a practice does not exist anymore. Vera Loča tells us:

One year it did not rain for a long time. Then the women took this icon we have here, of Saint Anthony. Then we started to walk around the village with these icons. In the evening, rain clouds began to appear. And in the morning it was already raining. That was a long time ago. Before the war. No, during the war.

Vera Savenko also remembers that there was a large icon that was carried around a burning building in order to put out a fire, and also in case one had started.

These customs - the healing of people and livestock with prayers, Catholic hymns and charms to prevent diseases, fire or drought by icons of saints - established by Catholics in medieval times (including the activities of religious orders, for example, Jesuits), are no longer practised in Latvia today, although they have been preserved in Timofeyevka and were still maintained during the Second World War. Over time these activities have transformed from an official custom into an informal practice, which can be defined as magic. Therefore it is not possible to draw a strict division between religion and magic in the experience of Latvians in Timofeyevka. Straubergs also reached the same conclusion when considering the interrelationship between religion and magic in Latvians' experience in Latvia: "Wherever there is religion, there is magic, the signs of which become ever more similar: a belief in supernatural powers, which people are able to use" (Straubergs 1923: 805). The division only exists when one of these is considered to be a higher cultural construct, although with this approach we return to the late 19th century discussion about magic and the understanding of religion. The community has been creating a religion of its own since the 1930s, when the church was closed down in Timofeyevka, by repeating the stories that had already been heard, and experiencing new ones, in this way gaining validation for their own worldview. 
One can observe opposing tendencies in the preservation and functioning of traditional cultural material in Timofeyevka and other Siberian Latvian villages - congelation and convergence. Isolation and the emphasis of difference from other local communities (denominational and language-based) help to defend traditions from outside influences, for some time. On the other hand, economic, political or other types of contacts are prerequisites for a minority culture to merge with the landscape of the era and the place - both Soviet and Slavic traditions. If this contact is intense, then the unification of culture will be faster. Language and a broad range of inherited traditions have been preserved in Timofeyevka due to the location of the village: it is situated away from large cities and main roads. In turn, by merging with similar Slavic traditions, some customs have still been maintained in active use, although in a slightly different form, for example, in Easter, Pentecost and Midsummer celebrations.

However, the question remains about the influence of Slavic (Russian, Byelorussian and Polish) culture in Latgale prior to the time that the settlers of Timofeyevka left Latvia, and its influence on the following generations when they had already settled down in Siberia. The evaluation of this question is hindered by the fact that Latvians in Timofeyevka (the same as in Latgale) have lived side by side with the Slavs. Polish settlers also lived in the area around the village, and were regarded as more similar to Latvians than Russians, and were better accepted in Timofeyevka because of their Catholicism.

Timofeyevka's seasonal and family customs as well as belief legends and stories of personal experience demonstrate that these can be included in the sum total of Latvian customs and traditions, with a narrower localisation - Latgale, as can also certain aspects borrowed from Slavic culture. The simplification of tradition occurs both in Latvia and Timofeyevka, although the community in Timofeyevka has been successful in preserving particular traditions or their features, which have disappeared much sooner in the Latvian experience: for example, riding horses at Shrovetide. New variations of traditions have also been created: for example, smoking out a grave with the pages of a prayer book.

The Latvian community in Timofeyevka has knowledge of the divine, which manifests itself in various traditional situations. Seasonal celebrations, family rituals and also daily celebrations can be related to both religion and magic, which are tightly interwoven to create one overarching conceptual system. When examining the traditional heritage of Timofeyevka in the context of other Siberian Latvian villages, it stands out as being one of the richest. 


\section{ACKNOWLEDGEMENTS}

This article has been elaborated by support of the European Social Fund within the project "Cultures within a Culture: Politics and Poetics of Border Narratives”, No. 1DP/1.1.1.2.0/13/APIA/VIAA/042.

\section{NOTES}

1 The main traits distinguishing Latgalians from Latvians are the language (High Latvian dialect) and religion (Catholicism). In the recent Russian census Latgalians and Latvians were still shown as different nations. In this article the author uses the terms Latvians and Latgalians as synonyms, including the Latvians of Timofeyevka, with their adherence to Catholicism and their language based on the High Latvian dialect, which is a dialect of the Latvian language.

2 The Office of the Dead is a tradition of a musical performance, which is linked to funerals and the remembrance of the deceased on certain subsequent days, as well as to annual family events dedicated to the departed. The tradition has been widespread mainly in the Latvian Catholic community in Latgale, the eastern part of Latvia, since the end of the 18th century, and continues to be practised today.

\section{MANUSCRIPT SOURCES}

Fieldwork materials from 2004 and 2006 in possession of the author.

\section{REFERENCES}

Boiko, Mārtiṇš 2002. Tikšanās ar mirušajiem sapṇos: tipizēti un netipizēti stāstījumi un to funkcionālie un kultūrvēsturiskie konteksti. [Meeting with the Dead in Dreams: Typical and Non-Typical Stories and Their Cultural-Historical Contexts.] In: Agita Lūse (ed.) Cilvēks. Dzīve. Stāstījums. [Man. Life. Narrative.] Rīga: LU Literatūras, folkloras un mākslas institūts \& Latvijas antropologu biedrība, pp. 115-125.

Brolišs, Jāzeps 2000. Latgales latviešu likten,i Sibīijīā. [Latgalian Fates in Siberia.] Rēzekne: Latgales kultūras centra izdevniecība.

Čudare-Erina, Broṇislava 2005. Svētki un svinamās dienas Latgalē. [Festivities and Holidays in Latgale.] In: Inese Paklone (ed.) Nomales identitātei. [To the Identity of Outskirts.] Rīga: Madris, pp. 141-209.

Fursova, Elena 2003. Kalendarnye obychai i obriady vostochnoslavianskikh narodov Novosibirskoi oblasti kak rezul'tat mezhetnicheskogo vzaimodeistviia. [Calendar Rites and Rituals of East Slavic Peoples of Novosibirsk Oblast as a Result of Interactions.] Part 2. Obychai i obriady letne-osennego perioda. [Customs and 
Rituals of the Summer-Autumn Period.] Novosibirsk: Institut arkheologii i etnografii SO RAN.

Jansons, Jānis Alberts 1937. Maǵija latviešu tautas tradīcijās. [Magic in Latvian Folk Traditions.] Rīga: Valters un Rapa.

Jansons, Jānis Alberts 2010. Latviešu masku gājieni. [Latvian Mask Processions.] Rīga: Zinātne.

Jurevičs, Ontons \& Meikšans, Jezups 1933. Bazneicu puorverssim par kuḷturas neseju. [Let's Turn the Church into a Culture Bearer.] Newspaper Taisneiba, No. 56, June 26, p. 4. Available at http://www.periodika.lv/periodika2-viewer/view/indexdev.html\#panel:pp | issue:/p_001_taip1933n056| article:DIVL171|issueType:P, last accessed on July 2, 2014.

Kīlis, Roberts 2002. Nodomu valoda: atbildība un vainošana Babraukas ciema iemītnieku stāstos. [The Intent Language: Responsibility and Blame in the Stories of Inhabitants of Babrauka Village.] In: Agita Lūse (ed.) Cilvēks. Dzīve. Stāstījums. [Man. Life. Narrative.] Rīga: LU Literatūras, folkloras un mākslas institūts \& Latvijas antropologu biedrība, pp. 81-94.

Kolotkin, Mikhail 2012. Latgal'skie poselentsy v Sibiri. [Latgalian Immigrants in Siberia.] Achinsk \& Sankt-Peterburg: Filologicheskii fakul'tet SPbGU.

Krasnais, Vilberts 1938. Latviešu kolonijas. [Latvian Colonies.] Rīga: Latvju Nacionālās Jaunatnes Savienības izdevums.

Līdeks, Osvalds 1991. Latviešu svētki. Latviešu svinamās dienas. [Latvian Festivities. Latvian Holidays.] Rīga: Scientia.

Lielbārdis, Aigars 2007. Kalendārie svētki Sibīrijas latviešu un latgaliešu ciemos. [Calendar Celebrations in Latvian Villages in Siberia.] In: Baiba KrogzemeMosgorda (ed.) Meklējumi un atradumi. [Searches and Findings.] Rīga: Zinātne, pp. $156-175$.

Lielbārdis, Aigars 2008. Vārdošanas tradīcijas Vārkavā. [Charming Traditions in Vārkava.] In: Janīna Kursīte \& Jolanta Stauga (ed.) Vārkava: Tradicionālā kultūra un mūsdienas. [Vārkava: Traditional Culture and Today.] Rīga: Madris, pp. 192-206.

Lielbārdis, Aigars 2011. Latvieši latviešu acīm: Sibīrija. Timofejevka = Latvians about Latvians: Siberia. Timofeyevka. Rīga: Latvijas Universitātes Literatūras, folkloras un mākslas institūts.

Lielbārdis, Aigars \& Boiko, Mārtin̦š 2012. Psalmu dziedāšana Latgalē. Officium defunctorum $=$ The Office of the Dead in Latgale. Rīga: LU Literatūras, folkloras un mākslas institūts.

Lotkin, Ilia 1996. Sovremennye etnicheskie protsessy u latyshei i estontsev Zapadnoi Sibiri. [Contemporary Ethnic Processes of Latvians and Estonians in Western Siberia.] Moskva: Institut etnologii i antropologii im. N. N. Miklukho-Maklaia.

Mauss, Marcel 2006 [1972]. A General Theory of Magic. London \& New York: Routledge. Melnalksnis, Augusts 1933. Kolonijas, latviešu. [Colonies, Latvian.] In: Arveds Švābe \& Aleksandrs Būmanis \& Kārlis Dišlērs (eds.) Latviešu konversācijas vārdnīca. [Latvian Conversation Vocabulary.] Vol. 9. Rīga: A. Gulbja apgāds, col. 17113-17142.

Melnalksnis, Augusts 1938. Sibīrija. [Siberia.] In: Vilberts Krasnais. Latviešu kolonijas. [Latvian Colonies.] Rīga: Latvju Nacionālās Jaunatnes Savienības izdevums, pp. 286-342. 
Mežs, Ilmārs 2011. Statistiskās ziṇas par Sibīrijas latgaliešiem: Timofejevkas etnodemogrāfiskais apskats. [Statistical Information about Latgalians in Siberia: An Ethno-Demographic Survey of Timofeyevka.] In: Aigars Lielbārdis (ed.) Latvieši latviešu acīm: Sibīrija. Timofejevka = Latvians about Latvians: Siberia. Timofeyevka. Rīga: Latvijas Universitātes Literatūras, folkloras un mākslas institūts, pp. 69-81.

Muktupāvela, Rūta 2006. Atzīdeṇa fenomens latviešu un lietuviešu tradicionālajā kultūrā. [Phenomenon 'Atzīdenis' in Latvian and Lithuanian Traditional Culture.] Karogs, Vol. 4, pp. 82-92.

Reidzāne, Beatrise 2008. Latviešu svētku un svinamo dienu nosaukumu etimoloǵijas, to problemātika. [Etymologies of Latvian Festivities and Holidays: Problems.] Letonica, Vol. 18, pp. 232-246.

Salve, Kristi 1994. Lībiešu tautas kalendārs. [Livonian Folk Calendar.] In: Kersti Boiko (ed.) Lībieši. [Livonians.] Rīga: Zinātne, pp. 160-179.

Šḳilters, Kārlis 1928. Latkoloniju vēsture. [History of Latvian Colonies.] Maskava: Prometejs.

Skobajs, Piters 1928. Nabadzeiba organizejas un imovia tuklus bogotnikus. [Poverty Organised and Limited the Money-Bags.] Newspaper Taisneiba, No. 43, November 23, p. 2. Available at http://www.periodika.lv/periodika2-viewer/view/indexdev.html\#panel:pp| issue:/p_001_taip1928n43 | article:DIVL48 | issueType:P, last accessed on July 2, 2014.

Skrinda, Kazimirs 1910. Weiskupa ceľ̦s pa Sibiri. [Bishop's Path through Siberia.] Newspaper Drywa, No. 35, January 26, p. 4. Available at http://data.lnb.lv/nba01/ Drywa/1910/Drywa1910-035.pdf, last accessed on June 12, 2014.

Šmits, Pēteris 1940-1941. Latviešu tautas ticējumi. [Latvian Folk Beliefs.] Vols. 1-4, Rīga: Latviešu folkloras krātuve.

Straubergs, Kārlis 1923. Piezīmes pie dažām latviešu burvju grāmatām. [Remarks on Some Latvian Sorcery Books.] Izglïtżbas Ministrijas Mēnešraksts, No. 7, July 1, pp. 804-816. Available at http://www.periodika.lv/periodika2-viewer/view/index-dev. html\#panel:pp|issue:/p_001_izmm1923n7| page:58|issueType:P, last accessed on July 2, 2014.

Straubergs, Kārlis 1935-1936. Maǵija. [Magic.] In: Arveds Švābe \& Aleksandrs Būmanis \& Kārlis Dišlērs (eds.) Latviešu konversācijas vārdnīca. [Latvian Conversation Vocabulary.] Vol. 13. Rīga: A. Gulbja apgāds, col. 25146-25250.

Strautniece, Vaira 1995. Lejas Bulāna-latviešu ciems Sibīrijāa. [Lejas Bulāna: A Latvian Village in Siberia.] Rīga: Zvaigzne ABC.

Tihovskis, Heronīms 1993. Kāzu paražas Latgalē. [Wedding Customs in Latgale]. Rīga: Zinātne.

Ulanowska, Stefanija 1891. Łotysze Inflant polskich. [Latvians of Polish Livonia.] In: Zbiór wiadomości do antropologii krajowej. [Collection of News in Regional Anthropology.] Vol. 15. Krakow: Akademia Umiejętności, pp. 181-282. Available at http://dlibra.umcs.lublin.pl/dlibra/docmetadata?id=1707\&from=publication, last accessed on June 13, 2014. 
Zēvers, Jānis 1925. Kāds 150 gadus vecs, līdz šim nepazīstams katḳisms latgaliešu izloksnē. [A 150-Year-Old and Unknown Catechism in Latgalian Dialect.] Izglītības Ministrijas Mēnešraksts, No. 6, June 1, pp. 601-609. Available at http://www. periodika.lv/periodika2-viewer/view/index-dev.html\#panel:pp|issue:/p_001_iz mm1925n6 | article:DIVL121 | page:43 | block:P43_TB00002| issueType:P, last accessed on July 2, 2014. 


\title{
THE FUNERAL CULTURE OF ESTONIANS IN THE MINUSINSK REGION, SIBERIA, AS A REPRESENTATION OF THE COMMUNITY AND ITS TRANSFORMATION
}

\author{
Anu Korb
}

\begin{abstract}
The article discusses the death and funeral culture of Estonians inhabiting the Minusinsk region in East Siberia as a representation of the community's solidarity and a sense of belonging, while observing changes in the funeral culture. The majority of Estonians living today in the Minusinsk region are descendants of the peasants who migrated to this area in search of free land in the last quarter of the 19th and at the beginning of the 20th centuries, or were deported from Estonia or forced to settle in Siberia after had been passed the tsar's law in 1845, according to which the region was defined as the Lutheran settlement in East Siberia.

Most of the Estonians who later migrated from urbanised villages to towns remained closely connected with their home village and therefore considered themselves as part of the Estonian community. The funeral culture of Estonians in Siberia is inseparably connected with the Lutheran liturgical tradition and the Estonian language. Regardless of abrupt political changes (the Bolsheviks' return to power, banning of all religious activities, repressions, wars, etc.), religious funerals have survived as part of the tradition. Funeral rituals are officiated by village buriers, who have to pay notice to other community members. The most direct function of such collective ritual practices is to unite the community. The community's funeral practices clearly reflect group identity, attempts to observe ancestral customs, emphasising the importance of helping each other in the community. Along with changes in society, times of crisis, political situation, the influence of multicultural environment, the growing number of mixed marriages, etc., the funerary tradition is also undergoing a transformation.
\end{abstract}

Keywords: community, death and funerary culture, Estonians, identity, multiculturalism, Siberia

\section{SOURCES}

The article explores the changes that have occurred in the funeral culture of Estonians in the Minusinsk region, Siberia, over the past few decades. The analysis of death and funeral customs is largely based on the material collected by the author, who carried out fieldwork in the area from 1991 to 1992 
and, again, a few decades later, from 2012 to 2013. During the 1990s, the author interviewed Estonians living in Siberian villages, and this material constitutes the majority of large-scale thematic interviews. From 2012 to 2013 , the collecting of the material was based on semi-structured interviews about biographical tendencies, supported by participant observation. Interviews of the second period involved, besides villagers, also Estonians who had moved to Siberian cities and towns. The material was collected mainly from middle-aged and older people, thus offering a glance at a somewhat earlier period. In terms of death and funeral culture, the most useful information was obtained from the women who had officiated burials in the village. They were familiar with the death-related tradition and acted as its primary shapers. In addition, the author was given a chance to take part in a funeral that took place in Verkhnii (Upper) Suetuk village in spring 2012.

Observations about the funeral culture of Estonians in the Minusinsk region have also been found in the material collected in earlier times, for example, in the collections of linguists Jüri Viikberg and Lembit Vaba (see, e.g., Viikberg $\&$ Vaba 1984), who visited the same communities in the 1980s. The article also makes use of the material recorded in the 1970s by Rosalie Ottesson, a Siberian correspondent of the Estonian Folklore Archives. Ottesson's descriptions of local death and funeral traditions seemed to be based on a detailed questionnaire entitled "Questions about funerary customs", compiled by Amanda Raadla in 1940 .

\section{TERMINOLOGY AND DEFINITIONS: THEORETICAL CONSIDERATIONS}

Even to this day, Estonians of the Minusinsk region in Siberia clearly stand out among their neighbours. The majority of Estonians who have resettled from villages to cities (e.g., Minusinsk) or the surrounding villages (e.g., Motorskii, Karatuzskoe) have remained closely connected with the people back in the home village, and therefore it is possible to treat them as part of the Estonian community. Cultural studies see the community as a culturally construed phenomenon, which, in addition to statistical connections, presumes to be culturally different from others, or features a sense of unity or belonging, which is suitable for characterising contemporary communities that are more open. The sense of belonging is, in turn, closely connected with the sense of identity. According to Stuart Hall (1999: 248-250), identity is a conscious strategy directed towards the future, serving the aims of a single individual or a group. The sustainability of diaspora communities depends on whether they have succeeded in estab- 
lishing structures that would be parallel to the social institutions of their host country, and how effectively they have maintained them. What is important is the community's collective will to exist as a linguistic-cultural community (Ehala 2010: 68-69), or its ethnolinguistic vitality (Giles \& Bourhis \& Taylor 1977: 307). The sustainability of a community thus depends on the influences of the external environment and the strength and ethnolinguistic vitality of the internal environment (see, e.g., Ehala 2010: 69). A positively perceived external environment (e.g., a naturally isolated habitat, adequate supply of resources) and social circumstances (absence of an imposing monocultural and dominant neighbourhood) have had a positive effect on the sustainability of Estonian village communities in Siberia (Kulu 1992: 57). The late 19th-century policies of Russification did not affect the Siberian Lutheran (among them Estonian) communities as strongly, since the local schools came under the jurisdiction of the village community and the Lutheran Church rather than the state. At the same time, the destructive policies of the Soviet regime have had a lasting negative influence (demolishing the ethnic structure of settlements, banning religious practices, etc.) on the community.

The key function of collective ritual practices is to unite members of the community. Arnold van Gennep (1977 [1960]), who has studied transition rituals, argues that the life of an individual member of the community consists of many transitions and that the individual's social position alters through these transitions. Death brings to the fore the most important community values (Jetsu 2001: 34). Death and funeral culture have been defined as the sum of different views and behaviours related to death (Pentikäinen 1990: 7), but also as a synthesis of death-related beliefs and practices, which is based on social contract (Ristolainen 2004: 11). How an individual perceives death and deathrelated behaviour is shaped under the influence of both community perceptions and external factors (e.g., the media, literature).

The article approaches the funerary and death culture of Estonians in the Minusinsk region as a representation of the solidarity of the community and the individual, a feeling of being part of the group. Rituals have a stabilising role in human relationships, whereas through a ritual an individual becomes aware of his or her identity (Greverus 1987: 258). Several authors, among them Victor Turner (1969), have pointed to the transformation of established social relationships in ritual contexts, in which key positions may be held by people with skills or abilities quite different than those in everyday life. At the same time, societal changes, times of crisis or political situations may abruptly change the function of a tradition in society. 


\section{ON THE HISTORY OF SETTLEMENT AND LATER DEVELOPMENTS}

The first Lutheran congregations in Siberia were founded as early as in the 18th century (Jürgenson 2002: 72). The first records about Estonians who settled in the Minusinsk region date back to the period after the 1845 law, according to which the region was defined as the Lutheran settlement in East Siberia. The population consisted mainly of free peasants who had been deported or forced to emigrate from homeland (Must 2012: 365). The Lutheran Church played a major role in the fact that at least part of the Estonians who had been forced to migrate to Siberia held on to their ethnic religion, language and national identity, and partly also cultural traditions and work ethics (ibid.: 466). Verkhnii Suetuk village became the first Lutheran settlement in the region, and Jüri Kuldem from Tobolsk Guberniia in West Siberia is known as the first person to settle in the village (ibid.: 383). A while later, after the colony became overpopulated, two additional Lutheran settlements were founded - Verkhnaia (Upper) Bulanka and Nizhnaia (Lower) Bulanka. From then on, Verkhnii Suetuk was intended for Finnish settlers, Verkhnaia Bulanka for Estonians and Nizhnaia Bulanka for Latvians and Germans (ibid.: 391-392). In reality, the population in the villages varied all the time, and the number of permanent settlers was rather low. Basic practical religious and educational activities in these Lutheran settlements were carried out by local vicars/schoolmasters, since the pastors' service area was far too broad.

In the final decade of the 19th century and in the early 20th century, the number of Estonians migrating in the course of agrarian colonisation started to grow. By that time, the majority of Estonians in the Minusinsk region were descendants of former emigrants. Ever since the foundation of the settlements, the emigrants complained about withering religious activities on the pages of Estonian newspapers (see, e.g., Postimees 1899: 1), even though there were several talented vicars/schoolmasters (Jaan Nebokat, Jüri Veem, and others) active in the Lutheran settlements of the Minusinsk region in the second half of the 19th and early 20th centuries. Among their responsibilities was the performing of baptising and funeral rituals. Jüri Veem is also known as the founder of a brass band in Verkhnii Suetuk village (Must 2012: 432-440), which has been active until the present day.

Religion has played a vital role in establishing the sense of 'us' group. During the spread of reformation movement in Estonia since the mid-19th century, part of the local population converted to Russian Orthodoxy owing to economic and social conflicts; however, after migrating to Siberia, many of those who had become Orthodox Christians in their homeland chose to reconvert to 


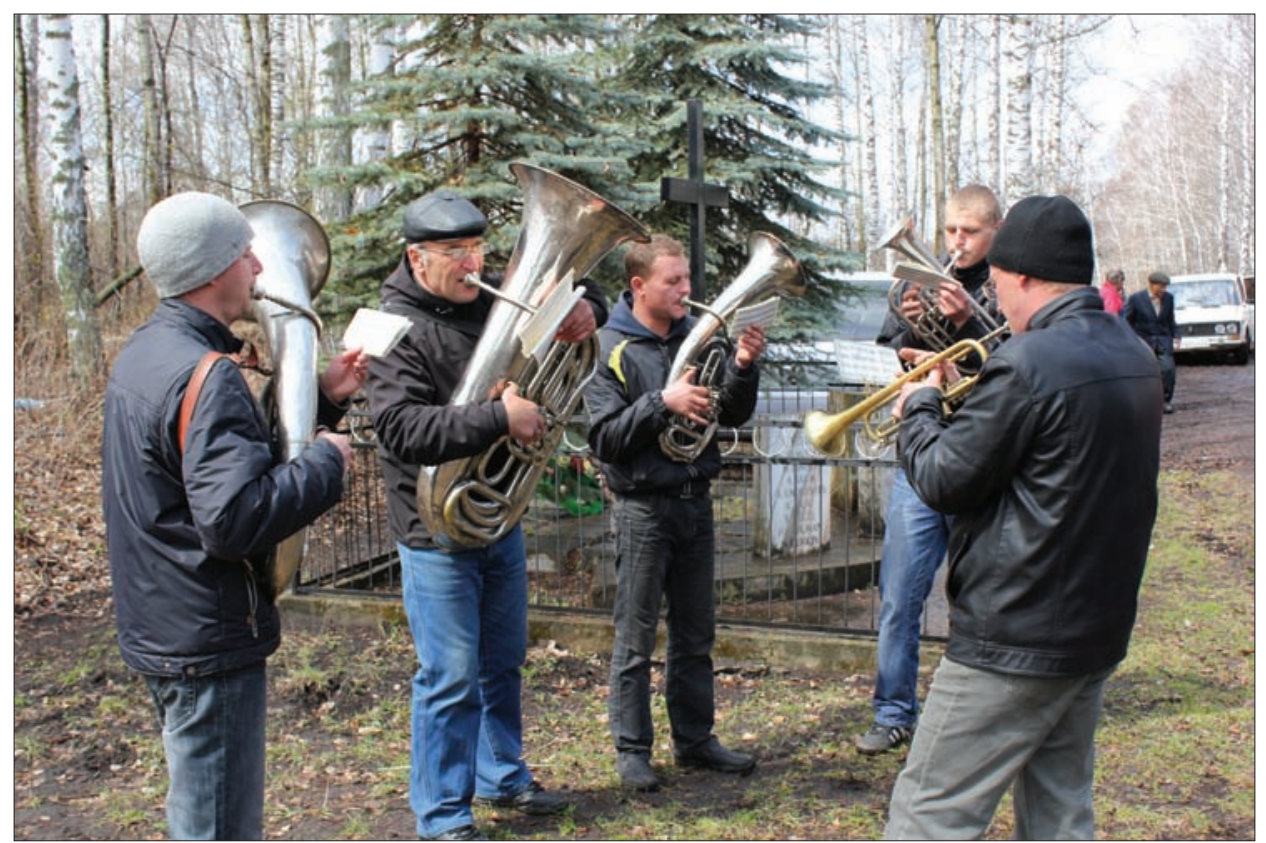

Figure 1. In Verkhnii Suetuk village the deceased is sent off to the accompaniment of brass band music. Photograph by Andreas Kalkun 2012.

Lutheranism (Jürgenson 2002: 228-229). The Estonian settlers have continued to refer to Lutheranism as 'our/Estonian faith'. As compared to the Orthodox, Lutherans of other nationalities (Latvians, Finns, and Germans) were more readily accepted as 'us'. In the events after the Bolsheviks' return to power in 1917, the most entrepreneurial and financially successful people - the socalled kulaks - suffered the most. Religious life, and later also the closing of ethnic schools, repressions and the foundation of collective farms paralysed the established routine in the communities. After the Second World War, larger villages were turned into multi-ethnic settlements, while the population in the villages off the major central roads, such as Verkhnii Suetuk and Verkhnaia Bulanka, continued to decrease as the villagers moved to the cities and towns of Russia and also elsewhere.

Quite a considerable number of those who left the villages of this region decided to relocate within the same province, settling in the city of Minusinsk, the district centre Karatuzskoe, or the surrounding Russian villages. At the same time, during the period that Estonia was annexed by the Soviet Union 
(1940-1941, 1944-1991), there was a mass repatriation to Estonia, the ancestral land, from Siberian villages and settlements. Estonians of the Minusinsk region have traditionally had a relatively close contact with their compatriots in homeland: visiting relatives, keeping up correspondence, sending books, clothing and other goods from Estonia, and cedar seeds, honey, wool, etc. from Siberia. The vastly changed economic situation (hyperinflation, unemployment) and political atmosphere (Estonian-Russian border disputes) after the collapse of the Soviet Union brought an abrupt change also into the lives of Estonians in the Minusinsk region, after which contacts with Estonia lessened considerably (Korb 2008: 56-58). Since the first decade of the 21st century, cross-border communication has become more active, owing to the increasingly frequent visits and rapid technological advances (phone technology, Skype). The Estonians who live in this region of Siberia do not have a socially constructed community, but they meet each other at Lutheran services or social gatherings in the homes of their acquaintances and kin. After all, the Estonian population in Siberia is decreasing.

\section{CHANGES IN FUNERAL CULTURE UNDER THE SOVIET REGIME}

The funeral culture of Estonians in Siberia is inseparable from the Lutheran tradition and the Estonian language. After the Bolsheviks' return to power and the banning of all religious ritual practices, an attempt was made to establish new Soviet traditions, which were national in form but Socialist in content. The aim was to free transition rites from the rule of the Church (see, e.g., Heikkinen 1985: 123). In fact, the Estonians in Siberian village communities never really abandoned the word of God, even at the funerals of party functionaries. In public, people tried to appease the Soviet authorities, but in private they still turned to God. Informant Rosalie Ottesson retrospectively describes the situation in a letter to Igor Tõnurist ${ }^{1}$ in 1967:

Should a Communist or a Komsomol functionary die, they make a cross and a pentangle upon that cross. Today one is buried with an official speech and to revolutionary songs, but tomorrow, when the chapel is empty, a religious father or mother will be summoned to say a prayer and sing at the grave of the one who was buried the day before without the Bible, songs or sermon. (R. Ottesson's letter from Verkhnii Suetuk to I. Tõnurist, 1967) 
Research into Siberian Estonians suggests that the Soviet authorities were relatively lenient towards the use of the Bible: they probably hoped that the new Soviet customs would eventually push aside the old traditions and that the younger generation will abandon the old ways and adopt the new Soviet ones. Although Rosalie Ottesson came from a traditional village community, she was at the same time an avid supporter of the Soviet regime and justifies the Christian burial of her mother in the 1960s as follows:

I was a Communist, there were four of us, sisters - my sisters were not Party members, our mother died. There was a question of how we will bury our mother, whether [to give her] a Christian or a non-Christian funeral. [...] So we concluded that there must be some consistency, most of us agreed to organise a religious funeral, and so we did. Had there been a brass band or someone singing newer songs, then we might have used them, but since there was not, we had to follow the old traditions.

(R. Ottesson's letter from Verkhnii Suetuk to I. Tõnurist, 1967)

It is known that one of Ottesson's sisters was a village burier, which was another reason why a non-religious funeral could not have been held.

In Estonia, secular funerals emerged in the Soviet period and have been arranged until the present day, side by side with religious funerals. Members of a congregation are usually buried by a local pastor, while non-religious funerals are carried out by a secular minister, often employed by the local funeral office. After the restoration of independence in the Republic of Estonia, there are also private entrepreneurs offering funeral services. In the culture of Siberian Estonians, funerals were predominantly religious, and the ceremonies were led by a local burier. The village community accepts the tradition as it has evolved.

\section{VILLAGE BURIERS IN SIBERIA}

It is known that immediately after settling in Verkhnii Suetuk, and during the period when there was no pastor in the village, baptising and funeral rituals were performed by Jüri Kuldem (Must 2012: 384). Regretfully, the author of this article has no corresponding information on other settlements in the region. During the period when vicars/schoolmasters were active in the settlements, they were the ones to perform funeral ceremonies. After the 1920s-1930s repressions of the mainly male-dominated clergy, the performing of religious rituals was taken over by village buriers, who were usually women (Jürgenson 2000: 42-44). The same situation is common to several other peoples in Russia (see, e.g., Kallatsa 1994: 26-27). The reason for that was that women were not 
directly under the threat of being deported. The repressions of 1936-1938 left no village untouched: in many Estonian villages in Siberia, nearly all adult men were deported.

The Second World War took the few remaining men from the villages to the frontline. After the war, the share of men in the villages grew, but they still remained a minority. Over time, the Estonian villages in Siberia grew accustomed to the leading role of women. Since women tend to be more conservative by nature and more prone to preserve traditions, and somebody needed to perform rituals in the community, women assumed the responsibility for carrying them out (see Korb 2004: 111-117). The required skills were passed on hereditarily. Village buriers were and still are highly aware of the importance of their responsibility and tried to improve their knowledge as best they could. One of the main problems was the scarcity of books on liturgical practices in the villages. Certainly, there were fewer such books than there were Bibles and hymnals to begin with. The majority of Estonian-language literature was destroyed during 1936-1938, the years of repressions, and very few were courageous enough to hold on to religious books; however, if they did, the books were carefully kept hidden. Thus, each and every existing book on religious rituals was sought after and borrowed in case of necessity. After the 1990s, new editions of Bibles, hymnals and other religious books were brought and sent to the Estonian villages, but books on liturgical practices for baptising and funerals were not among them. The Estonian village buriers in Siberia often kept manuscript notebooks, in which they stored the necessary prayers and songs. Even if a burier had at her disposal the notebooks of her predecessor, she still tried to copy the required prayers and songs in her own hand - for easier use. The Siberians who have been schooled in the Russian language tend to struggle with Estonian orthography, so the copied texts are often with errors and omissions.

The songs sung at funerals are usually copied from manuscript notebooks; some have been taken from hymnal sheets used at funerals in Estonia. Of the funeral songs sung by Siberian Estonians, only a few are associated with a specific part of the ritual - for example, the song "Las ma lähen...” (Let me go...) is sung when the deceased is carried outside, and the song "Mu rahukamber valmis..." (My chamber of peace is waiting...) is sung when the coffin is lowered to the grave. However, most of the songs could be sung in any order both at the wake and during the funeral. Depending on the situation, the songs may be adapted. The repertoire varies significantly from village to village. Also, the share of religious and non-religious songs differs from one village to another (see Korb 1998: 153).

Larger Estonian communities in Siberia (e.g., Verkhnii Suetuk village) have never been without a burier: 
They passed it on from generation to generation; well, they passed on the liturgical texts of funerals from one generation to the next, and so they conduct funerals. [...] They do it in Estonian. The present one has been [a burier] for as long as I can remember, but who was before her? Anni Matsi, after that the one from Ploomi, and, let's see, the fifth or sixth was Juhanna Paap, who was [a burier] for a long time. And after her, it was me, and Miina Villa is the most recent one. ERA, DH $189(5)<$ Verkhnii Suetuk v. < man, born in 1942 (2009).

Most of the buriers were elderly women, although occasionally also a middleaged woman could become one:

Oh, I don't even remember anymore when I carried out my first baptism. It seems to me I baptised the first child 42 years ago, and now buried her. ERA, DV $130<$ Verkhnii Suetuk v. < woman, born in 1920 (2000).

If someone showed interest in becoming a burier, they could learn the trade on their own:

But did anyone teach you? - No, I started to read the books myself. [...] In 1938, my father was deported; they took the Bibles and all. And so I got this urge to read them [...].

ERA, DV 130 < Verkhnii Suetuk v. < woman, born in 1920 (2000).

The understanding that a burial without a religious funeral would be a breach of the community's norms has forced some village buriers to pass on their funeral texts:

I copied these in notebooks. And gave quite many to the [Verhknaia] Bulanka village and have given these to many, so they would start to read them. I used to perform funerals in Bulanka and then I have Juhanna of Saare's ones that I have copied. So you could bury, and sing like that yourself and bury.

ERA, DV 130 < Verkhnii Suetuk v. < woman, born in 1920 (2000).

The village burier, who could feel her death approaching, sometimes chose the next burier from among the villagers, also handing over the books on liturgical practices at her disposal:

Juhanna had so many of these books, she gave them to Jaan. So that he would become the next burier. Jaan still has these books, I think. There are those about how to conduct young people's funerals and those. Books, yes, Juhanna got these from ministers in Estonia, who sent these.

ERA, DH 436 (6) < Verkhnii Suetuk v. < woman, born in 1940 (2012). 
The same Jaan, who was Juhanna's successor as a burier in Verkhnii Suetuk for a while, studied theology in Krasnoyarsk in the late 1990s and became an official pastor's assistant. He describes his journey to the profession as follows:

So the Finnish church officials came there [to Verkhnii Suetuk], and we were sending our nephew to the army. Then we started to talk and I am asking: What are you looking for? That, here's the church, right, and according to law, the church was built by the Finns, in $1888 .^{2}$ That if you want to do some work, then work and rebuild the church. There were quite many people in the village back then, and so they asked me to come to this seminary in Krasnoyarsk. [...] I was already retired, but then I attended this seminary, for a year and a half, I think. [...] It was a distance-learning course; I went there thrice a year. [...] And there it was, I completed the studies, came back and worked, I was given the position of catechesis ${ }^{3}$ and the right to perform funerals and baptisms and hold sermons. But Juhanna Paap fell ill and she was the first person to whom I gave a church funeral. Of course, I may not have performed the funerals according to all the rules. I followed the example of movies at the cinema, nobody taught me. Had I been taught to conduct funerals or baptisms? No, I was only taught theology. [...]

ERA, DH 189 (15) < Estonia, Turba < Verkhnii Suetuk v. < man, born in 1942 (2009).

And so Juhanna died and this Jaan took her to the church. And nobody else had ever taken a dead person there. But then they did. Juhanna was taken to the church, and then from there she was taken to the graveyard. [...] They objected, of course, but took her anyway. - Who objected? - Well, plemianniks ${ }^{4}$, and they were so against it, but it didn't matter.

ERA, DH 433 (8) < Verkhnii Suetuk v. < woman, born in 1934 (2012).

While in Estonia, the deceased may be sent off from both the church and home (Paenurm 1995: 47), whereas a sendoff from the church was highly uncommon in Siberian Estonians' funeral tradition. In many Estonian villages in Siberia, no church had been built; instead, they used a school which doubled as a prayer house. The burier's wish to send the former village burier off from the church met strong opposition in the village. Jaan did not stay in the job of an officiant for long, as the villagers never truly accepted him. Another obstacle to his keeping the position was that he could not sing.

In retrospect, the people of the Minusinsk region believe that "Juhanna was good at funerals, she also did it for many, many years."

ERA, DH 433 (8) < Verkhnii Suetuk v. < woman, born in 1934 (2012). 
In the meanwhile, they are pleased with their current burier, Miina: "But now we have in Suetuk, when you go, you'll definitely meet Miina. She is in the village, conducting all the burials, Miina Villa."

ERA, DH $427(25)<$ Minusinsk city < Verkhnii Suetuk v. < women in a group (2012).

\section{DEATH OF A COMMUNITY MEMBER AS A REPRESENTATION OF GROUP IDENTITY}

In a Siberian village community, the death of a community member involves not only the family and relatives of the deceased but the entire community. Villagers of more advanced age traditionally prepare for their own funeral: set aside coffin clothes (Mikkor 2001: 108; Torp-Kõivupuu 2003: 129) and money for the funeral, as is customary in Estonia. If an elderly person has no children, or they live far away, they also choose someone to arrange the funeral. Formerly, people had even their coffin boards ready; the coffin was made by local craftsmen right after the death (Korb 2004: 120). The same custom has been noted among the rural population in Estonia (Mikkor 2001: 113). Today, elderly people often complain that the procured coffin boards are not needed anymore; it is easier to buy a ready-made coffin in the city or region centre. Contemporary coffins in Siberia are covered with black or red cloth. In recent years, coffins have been equipped with handles, while earlier on a coffin was laid on a few plank boards, and was carried by ropes, or sometimes towels, as was customary among Russians (Korb 2004: 120-121). Although not common in the Estonian tradition, the Estonians in the villages of the Minusinsk region often have a cross ready before death. This is mostly an iron cross forged by a local smith. The tradition of making preparations for death has been largely upheld by the lack of adequate funeral services in the Soviet Union (Mikkor 2001: 105) and the overall deficiency of commodities.

A funeral feast is usually held in the home of the deceased. If the house happens to be too small, the deceased may be seen off from some larger neighbouring house. A dignified sendoff of the deceased is considered highly important; the funeral becomes a shared event, a demonstration of unity:

They take it to the funeral house, some give butter and cream. In Bulanka, a villager buries another, the other yet another. Whether you have a relative or not, they will still bury you.

RKM II 449, 52 (69) < Verkhnii Suetuk v. < woman, born in 1936 (1992). 


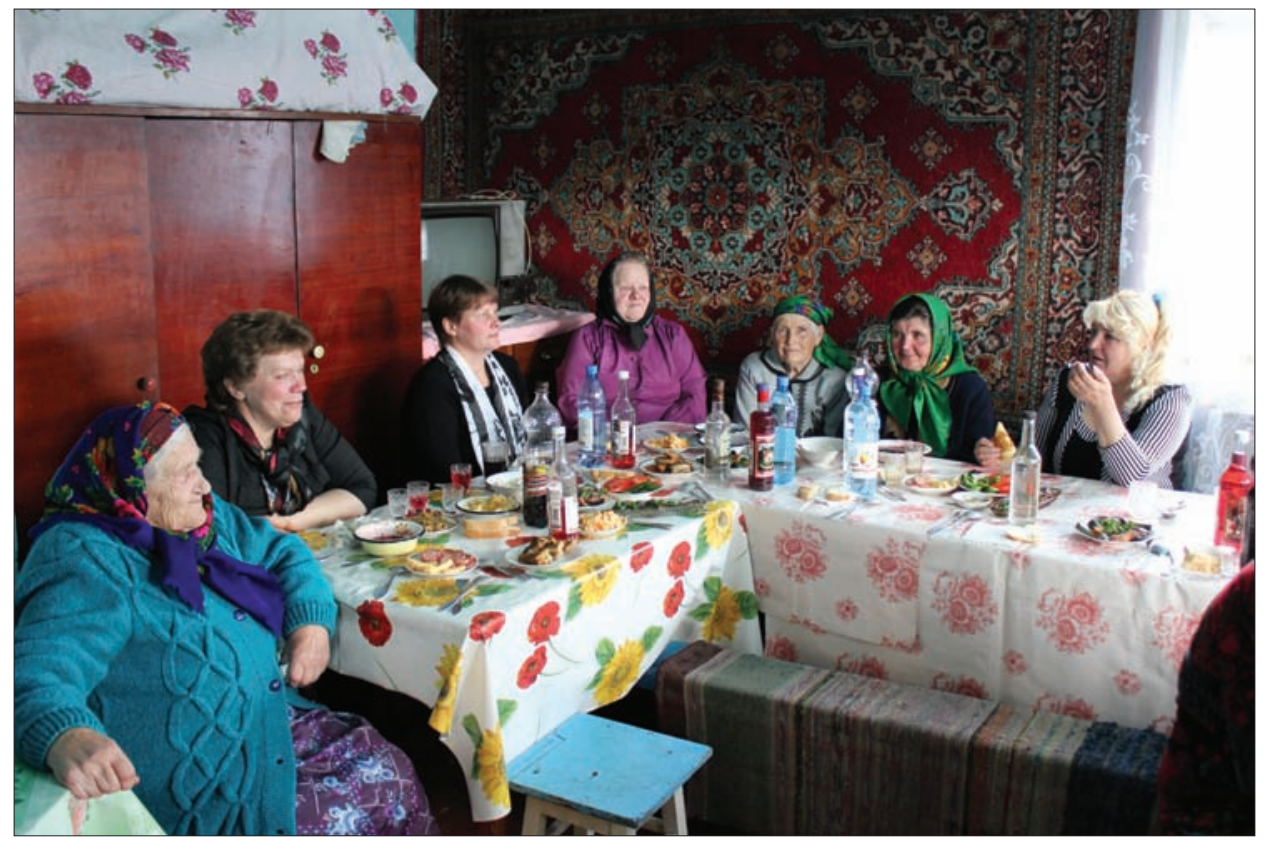

Figure 2. Women at funeral table. Verkhnii Suetuk village. Photograph by Andreas Kalkun 2012.

Bringing food does not necessarily mean that the family actually needs it: it is more the old habit of reciprocal helping, still very common in a village community. A similar helping out with food is part of the funeral tradition in southeast Estonia (Torp-Kõivupuu 2003: 73) and is known among many peoples, for instance, among the Finns (Vuorela 1977: 623). If the deceased community member came from a poorer family, the donations were larger; according to tradition, all members of the community must be sent off with dignity. This way everybody in the community contributes to the funeral feast, which is very lavish. Having a traditional funeral is a matter of prestige.

The women who are invited to prepare the funeral feast in Siberian Estonians' communities do not refuse without a good reason. In the Minusinsk region, the women who set the funeral table are called triapkas $\mathrm{s}^{5}$. These helpers are given an apron as a thank-you gift. One woman who had often been asked to help at funerals claimed that she had at least twenty aprons as gifts. But when in spring 2012, a woman who lived in Sweden and had not made it to her parent's funeral, offered second-hand clothes as a gift to the helpers, the villagers perceived it as odd. 
While in earlier times funeral guests were offered food twice both in Estonia and among Estonians in Siberia, today only one meal is served (cf. Mikkor 1992: 170-171). Among the compulsory funeral meals in Siberia is Estonian cabbage. Usually a larger animal is slaughtered for the funeral of a farmer or his wife. The ritual killing of an animal or a bird for the funeral has been observed both in Estonia and among many other nations (see, e.g., Salve 2000: 130). The funeral menu of Estonians in Siberia is more or less the same than that of any other feast held to celebrate holidays or festivities. The funeral feast that the author witnessed in Verkhnii Suetuk village in the spring of 2012 was extremely sumptuous: first noodle soup with meat balls was served, then came cutlets, mashed potatoes, jellied meat, potato sausage, and fried fish; there was white bread, herring, mackerel, and different salads on the table. A little later, prossa or millet porridge, thickened juice, tea, bliny (small buckwheat pancakes), pies, fruit, candy, and the local delicacy, cake with ground bird cherry berries, were served. Also, a larger variety of alcohol was offered (Korb 2012: 189). Given that generally only store-bought vodka is offered at the funerals among Siberian Estonians (Korb 2004: 130), at this funeral there was also self-made moonshine, sloe brandy ${ }^{6}$ and cranberry wine. The deceased had made arrangements with the neighbour five years before, upon her leaving to the retirement home, and had even given the neighbour money to pay for the funeral. Now the person who arranged the funeral made everything possible to please the villagers.

Siberian Estonians do not leave an empty seat at the table for the deceased, as is traditional in Estonia. If in Siberia there is less room at the table, funeral guests take turns eating. The guests leave immediately after the meal. In former times, funeral feasts lasted longer: the guests were offered a hot meal upon their return from the graveyard, after which they went home to tend to animals or cattle and returned later for the evening tea. A characteristic feature of a funeral feast in Verkhnii Suetuk village is that women and men are seated at different tables; the custom has probably roots in Christian culture.

It is important to observe ancestral traditions in performing funerary and death-related rituals. For example, the funeral tradition of Estonians in the Minusinsk region entails a custom of turning around the benches, on which the coffin was placed, after the deceased has been taken outside. The meaning behind this magic-protective ritual - most likely, to avoid a new occurrence of death in the house - is no longer known, but the ritual is performed nevertheless.

While today Estonians in Siberia believe that it is bad luck to dig the grave of one's close relative, in earlier tradition, both in Siberia and Estonia, gravediggers were often relatives of the deceased (Korb 2004: 122). Estonians in the 
Minusinsk region choose gravediggers from among the members of the community. The diggers do not get paid for the job, but are given a bottle of vodka, and often also a pair of knitted mittens in return for the service. In Verkhnii Suetuk village, which has the oldest brass band in Siberia (established in 1901, see Alaverdian 2001), the deceased is sent off to the accompaniment of brass band music. The band is not paid for playing at the funerals that are held in their home village.

On the day following the funeral, a small group of people traditionally visit the grave, saying prayers and singing funeral songs.

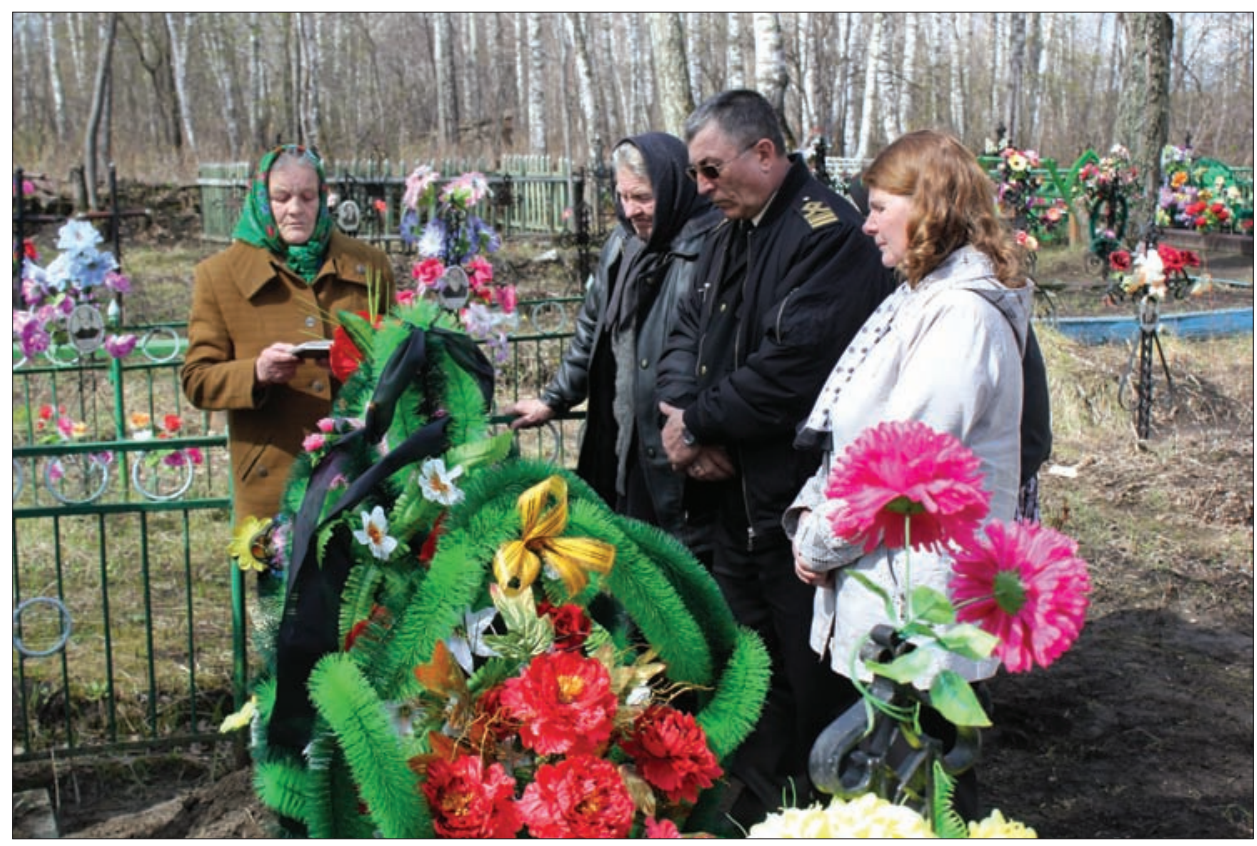

Figure 3. On the day following the funeral, a group of people visit the grave, saying prayers and singing funeral songs. Photograph by Andreas Kalkun 2012. 


\section{CHANGES IN THE FUNERAL TRADITION IN RECENT DECADES}

These days, the population of Estonian villages in Siberia is rapidly getting older and smaller. While social services in Russian villages are quite efficient (a caretaker is appointed by the village council to help an elderly person cope in daily life), adult children have the responsibility to take care of their aged parents. In the tough Siberian climate, people are accustomed to maintaining close contacts, and attending relatives and neighbours is taken for granted. A retirement home is considered to be the last resort if an elderly person is in need of constant care and has no children living nearby or none at all.

Given that many young people, who find little to do in the villages, have moved to the cities and towns, their aged parents have to spend their final days of life away from their home village. A beloved home village and house is left behind to move into a narrow space. The changed living conditions have also introduced changes in the funeral tradition: a dead body cannot be kept in a city apartment, the stairways of apartment blocks are too narrow to transport a coffin, etc. Also, the requirement imposed in Russia a few years ago that all the deceased must undergo autopsy further alters the tradition. Among the older generation, the forced autopsy requirement has elicited strong opposition. Once a deceased has been taken away from home, the washing and dressing of the body is often arranged by the funeral services, not by relatives.

The villagers who have moved to the city are often faced with the problem of either burying the deceased relative in the cemetery of the city or town where they live, or in the graveyard of the home village. After careful consideration of the pros and cons, decisions are made either way. The elderly, however, wish to be buried in the home village, next to their 'own' people. The ties connecting people with a location during their lifetime are believed to be stronger than death (Jürgenson 2004: 147). There are many examples of people living in exile who wish to be buried in the soil of their birth country (see, e.g., Grafik 1998: 310). The Estonians of the Minusinsk region, who have lived in Siberia for five to six generations, tend to view as their home Siberia, rather than Estonia. There are, of course, pragmatic considerations behind the decisions. Several aged villagers discussed whether someone's final resting place may depend on the weather conditions at the time of death. In cold winter weather it would be virtually impossible to fulfil the wish of the deceased to be buried in the home village graveyard, which is why the choice is made in favour of the cemetery nearest to the last place of residence. For example, the graveyard of Motorskii, a Russian village with a relatively large population of Estonians from Verkhnaia Bulanka village, has a separate section for Estonians (Jürgenson 2004: 145); this way the people of the village stay together even outside their home village. 
The younger generation prefers cemeteries in larger towns and cities also for practical reasons: this makes it easier to take care of the graves and visit the cemetery on commemoration days.

From summer 2007, the Evangelical Lutheran Church of Ingria takes care of the religious life of Estonians in the Minusinsk region. There is a Lutheran pastor in Minusinsk and also in the district centre Karatuzskoe, but visits to the Estonians in Verkhnii Suetuk, Verkhnaia Bulanka and the surrounding Russian villages are also made. The pastors do not speak Estonian, so the communication takes place and services are held in Russian. An Estonian pastor visits the Estonians of the region once a year, around St. John's Day. For Estonians it is important that the burial service of their compatriot is held in their mother tongue. Even though not all the funeral guests speak Estonian these days, a Russian pastor is not invited to officiate the funeral ceremony. The situation is quite analogous to that of Karelian Finns, who have resettled in Finland (see Davydova 2005: 1). In smaller villages and the surrounding Russian settlements (e.g., in Verkhnaia Bulanka with the population of about 40, and in Motorskii village), with no village burier any longer, a burier is summoned from Verkhnii Suetuk village. And should that prove impossible due to harsh weather conditions or for some other reason, the funeral is held by saying a prayer in Estonian.

Furthermore, the number of people who know and can sing Estonian songs is quite small in the villages:

There used to be so many singers. But by now they are all dead. Miina was one of them, how well she sang. And then there was Anni, Anni Uhvelt. [...] And then, Kostia, when he still came, then at the end with Miina, vaikka there are no other singers, but the two of them, they sang so beautifully. ERA, DH 433 (7) < Verkhnii Suetuk v. < woman, born in 1942 (2012).

In these days there are fewer and fewer people to officiate a funeral ceremony among the Estonians of the Minusinsk region, and so the tradition is broken with and changed. The existing village buriers are occasionally criticised as one or the other is not saying a prayer right, although the criticisers hardly know what the right way would be. Some villagers are concerned that when they die, there might not be a burier any more. For them, the most important thing is to preserve the tradition, and, compared to this, ethnic and in some cases confessional considerations are secondary. Since the tradition requires a religious funeral, also a local Russian-language Lutheran pastor may be called to officiate the funeral these days. On rare occasions a Lutheran Estonian has been buried by an Orthodox priest. At the same time, it is possible that a deceased, an Orthodox from a Russian village, is buried by an Estonian village 
burier, who performs the ceremony according to the Lutheran tradition and in Estonian.

In some Estonian communities in Siberia, for example, in Verkhnii Suetuk village, people used to visit the graveyard on Sundays. They visited the graves of relatives and acquaintances, often touching the cross or the grave monument. Women sat on a bench near a grave or the graveyard gate, singing death and funeral songs.

In earlier days, Estonians of the Minusinsk region used to celebrate only a year's passing from someone's death. By the present day, Siberian Estonians have adopted commemoration days, previously unknown to them, from the Orthodox Russians as part of their tradition. Thus they now celebrate the passing of 9 days, 40 days, and half a year from someone's death. On these commemoration days, a small group of the closest relatives visit the graveyard. Such visits may be quite complicated during muddy seasons, when the roads are falling apart. Most villagers and closer relatives who live elsewhere gather in the home of the deceased; people wear festive clothes: men are dressed in suits and white shirts, women wear mostly dark-coloured dresses. First they toast with a shot of vodka to commemorate the dear departed. When there is traditional food on the table (bliny with honey or kutya ${ }^{8}$ ), the guests have some of that. Then follows a hot meal and snacks and salads. In a few hours the commemoration meal is over.

The most important commemoration day of Estonians in Siberia used to be St. John's Day, and they did not have the custom of eating at the grave or leaving food there (unlike the Setos in Siberia). Visiting the graveyard during Whitsuntide and Easter was common also for the Orthodox Setos in Estonia (see Hiiemäe 1984: 213). In these days, Siberian Estonians also go to the graveyard on Whitsuntide and Easter. Even on May 9, the Russian national Victory Day, Estonians in Siberia traditionally commemorate the male relatives in graveyards, even if the relation of the deceased to the war is insignificant. Following the example of Russians, Estonians in Siberia have started to celebrate roditelski, the commemoration of parents, which is a work-free day in Russia.

Estonians in the Minusinsk region have an ambivalent attitude towards bringing food to the graveyard: some think that there is no need to take anything along, others pack a whole meal to go. In these days, some Estonians in Siberia place candy or cookies and various pastries on the graves. A glass of strong alcohol is placed on the graves of male relatives, and sometimes vodka is poured right on the grave.

The custom of burning candles on graves, which is becoming increasingly popular in Estonia, is gaining ground also in Siberia. Earlier on, candles were not even available in local stores. Over time, people have started to visit grave- 
yards on Christmas Eve and on New Year's Eve. Access to a village graveyard may be difficult in the winters with too much snow as the roads are cleared only for funerals.

\section{CONCLUSION}

Compared to other family traditions, the traditions related to death and funerals tend to be far more conservative and stable. The funeral traditions of Estonians living in the Minusinsk region in Siberia offer an insight into how a community functions under the collapse of a religious system: which parts of it are preserved and which are bound to change. In general, Estonians in Siberia wish to be given a religious funeral, following the Lutheran tradition and in the Estonian language, even though the social situation has not always favoured this. After the local clergy was deported, funeral ceremonies became the responsibility of non-professionals, mostly older women who were not under direct threat of being deported, and so it became part of women's tradition. Village buriers were more or less familiar with the community's funeral tradition, which was passed on from one person to the next by sharing experience, by word of mouth, if there was no literature available. Buriers are the primary shapers of a community's funeral tradition, but they have no authority without the acceptance of community members.

Collective ritual practices most directly serve the function of uniting the community. A group's identity clearly comes to the fore in funeral culture; members of the group try to act according to the ways of ancestors, and helping each other is considered important. Funeral culture is largely under the social control of the aged: deviations from established customs are frowned upon and people find it safer to follow the usual practice. The observation of old traditions gives the relatives of the deceased some peace of mind: by doing as always, the dead are believed to be pleased. On the one hand, the funeral and death tradition of Estonians in the Minusinsk region reflects the wish to continue the legacy of ancestors, but, on the other hand, in today's multicultural world people inevitably borrow some elements of tradition from the neighbouring, often dominant, culture: traditional Russian meals are served at the funeral feast, mourners observe the passing of 9 and 40 days from death, people visit the graveyard on Easter holidays and Whitsuntide, on May 9, and on the roditelski, the parents' commemoration day. The Estonians who were born and raised in the villages of the Minusinsk region are more often buried in the cemeteries of the city of Minusinsk or the district centre Karatuzskoe. The graves are beginning to look 
more like those of the local Russian population: they are surrounded by iron fences, grave monuments and wreaths of artificial flowers are made by local craftsmen and differ considerably from what is conventional in Estonia.

When discussing the funeral tradition, Estonians in Siberia clearly distinguish between the culture of 'us' and the culture of 'others', and are well aware of foreign elements in the tradition. The older generation prefer to preserve the ways of their forefathers and are more reluctant to adopt foreign traditions. In a multicultural environment, however, the adoption of some elements of the neighbouring tradition is inevitable. The results of such integration become more evident among mixed families, but also among Estonians living in cities and multi-ethnic villages. The levelling tendency of funeral traditions is further evidenced by the reciprocal summoning of buriers of different religious backgrounds and nationalities, in some instances also by officiating the funeral ceremony in Russian, which has already become a language to bridge the generation gap.

\section{ACKNOWLEDGEMENTS}

This work was supported by the Estonian Research Council grant number 9066 "Ethnic and National in Estonian Diaspora Communities", and by the institutional research funding IUT22-4 "Folklore in the Process of Cultural Communication: Ideologies and Communities" of the Estonian Ministry of Education and Research.

\section{ABBREVIATIONS}

ERA, DH - Estonian Folklore Archives, digital sound recordings on hard disc ERA, DV - Estonian Folklore Archives, digital video recordings RKM - Estonian Folklore Archives, manuscripts (1940-1995) 


\section{NOTES}

1 Igor Tõnurist and Rosalie Ottesson met in 1965. Tõnurist visited the Estonian settlements in the Minusinsk region of Krasnoyarsk Krai as an ethnography student of the Moscow University (Korb 2013: 10).

2 The oldest extant Lutheran church building in Siberia is situated in Verkhnii Suetuk village.

3 Pastor's assistant, catechism teacher, in Lutheran church.

4 Russ. plemiannik means 'nephew' or 'niece'.

5 Russ. striapat' means 'prepare' or 'bake food'.

${ }^{6}$ Russ. boiaryshnik means 'blackthorn'.

7 Fin. vaikka means 'although', 'even though'.

8 Russ. kutya - rice or barley cooked in honey, or with raisins added; a common Orthodox funeral food.

\section{REFERENCES}

Alaverdian 2001 = Alaverdian, L. (comp.) "I umiral i vozrozhdalsia vnov..." 100 let Verkhnesuetukskomu natsional'nomu narodnomu dukhovnomu orkestru. [100th Anniversary of Upper Suetuk National Brass Band.] S. Karatuzskoe.

Davydova, Olga 2005. Rituaali, identiteetti ja ylirajaisuus. Joitakin ajatuksia paluumuuttajan hautajaisista. [Ritual, Identity and Transnationalism: Some Thoughts on the Funeral of a Return Migrant.] Elore, Vol. 12, No. 1, pp. 1-22. Available at http://www.elore.fi/arkisto/1_05/dav1_05.pdf, last accessed on April 10, 2014.

Ehala, Martin 2010. Keel ja ühiskond. Väliseesti kogukondade jätkusuutlikkusest. [Language and Society: The Sustainability of Estonian Diaspora Communities.] In: Kristiina Praakli \& Jüri Viikberg (eds.) Eestlased ja eesti keel välismaal. [Estonians and Estonian Language Abroad.] Tallinn: Eesti Keele Sihtasutus, pp. 59-91. Available at http://www.eki.ee/books/eekv/EEKV.pdf, last accessed on April 10, 2014.

Giles, Howard \& Bourhis, Richard Y. \& Taylor, Donald M. 1977. Towards a Theory of Language in Ethnic Group Relations. In: H. Giles (ed.) Language, Ethnicity and Intergroup relations. London: Academic Press, pp. 307-348. http://dx.doi. org/10.1016/0024-3841(79)90051-2.

Grafik, Imre 1998. Nation, Nationality, National Minority. Acta Ethnographica Hungarica, Vol. 43, Nos. 3-4, pp. 307-325.

Greverus, Ina-Maria 1987. Kultur und Alltagswelt. Eine Einführung in Fragen der Kulturanthropologie. Frankfurt am Main: Institut für Kulturanthropologie und Europäische Ethnologie.

Hall, Stuart 1999. Identiteetti. [Identity.] Tampere: Vastapaino. 
Heikkinen, Kaija 1985. Folklorismin monet muodot. Esimerkki Neuvostoliiton juhlaperinteestä. [Some Forms of Folklore.] Tiede ja Edistys, Vol. 2, pp. 119-131.

Hiiemäe, Mall 1984. Eesti rahvakalender III. [Estonian Folk Calendar.] Tallinn: Eesti Raamat.

Jetsu, Laura 2001. Kahden maailman välillä. Etnografinen tutkimus venäjänkarjalaisista hautausrituaaleista 1990-luvulla. [Between Two Worlds: Ethnographic Study on the Funerary Rituals of Karelian Finns in the 1990s.] Suomalaisen Kirjallisuuden Seuran Toimituksia 853. Helsinki: Suomalasen Kirjallisuuden Seura.

Jürgenson, Aivar 2000. Kirik ja kool Siberi eesti asundustes. [Church and School in Estonian Settlements in Siberia.] Acta Historica Tallinnensia, Vol. 4. Tallinn: Teaduste Akadeemia Kirjastus, pp. 31-48.

Jürgenson, Aivar 2002. Siberi eestlaste territoriaalsus ja identiteet. [Territoriality and Identity of Siberian Estonians.] Tallinna Pedagoogikaülikool. Humanitaarteaduste dissertatsioonid 7. Tallinn: TPÜ Kirjastus.

Jürgenson, Aivar 2004. Kalmistu kodupaiga sümbolina: Siberi eestlaste näide. [Cemetery as a Symbol of Home: On the Example of the Estonians in Siberia.] Mäetagused, Vol. 25, pp. 143-156. doi:10.7592/MT2003.25.jyrgenson.

Kallatsa, Miika 1994. Karismaattiset naiset - Inkerin kirkon pelastus. [Charismatic Women: Ingrian Church Redemption.] Verso, Vols. 6-7, pp. 26-27.

Korb, Anu 1998. Siberi eestlaste lauluvara. [Songs of Estonians in Siberia.] In: Astrid Tuisk (ed.) Eesti kultuur võõrsil: Loode-Venemaa ja Siberi asundused. [Estonian Culture Abroad: Estonian Settlements in Northwest Russia and Siberia.] Tartu: Eesti Kirjandusmuuseum, pp. 143-157.

Korb, Anu 2004. Siberi eestlaste surma- ja matusekombestikust 20. sajandi viimasel kümnendil. [On the Death and Funeral Tradition of Estonians in Siberia during the Last Decade of the 20th Century.] Mäetagused, Vol. 25, pp. 103-142. doi:10.7592/MT2003.25.anudkorb.

Korb, Anu 2008. Eestlased Venemaal ja taasiseseisvunud Eesti. [Estonian Emigrants in Russia and the Newly Independent Estonia.] In: Kristi Anniste \& Kaja KumerHaukanõmm \& Tiit Tammaru (eds.) Sõna jõul: Diasporaa roll Eesti iseseisvuse taastamisel. [By the Power of Word: The Role of Diaspora in the Restoration of Independence in Estonia.] Tartu: Tartu Ülikooli Kirjastus, pp. 53-72.

Korb, Anu 2012. Eestlased ja setud Krasnojarski krai külades. [Estonians and Setos in the Villages of Krasnoyarsk Krai, Russia.] Mäetagused, Vol. 52, pp. 186-189. Available at http://www.folklore.ee/tagused/nr52/u01.pdf, last accessed on April $11,2014$.

Korb, Anu 2013. Rahvaluule osakonna Siberi kaastöölise Rosalie Ottessoni ja teaduritearhivaaride dialoog aastatel 1969-1976. [Researchers-Archivists and Siberian Correspondent Rosalie Ottesson: A Dialogue from the Years 1969-1976.] Mäetagused, Vol. 54, pp. 7-26. doi: 10.7592/MT2013.54.korb.

Kulu, Hill 1992. Eestlased maailmas. Ülevaade arvukusest ja paiknemisest. [Estonians in the World: Population and Geographical Locations.] Tartu: Tartu Ülikooli Kirjastus.

Mikkor, Marika 1992. Kaukaasia eestlaste matusekombestikust. [Funeral Traditions of Estonians in the Caucasus.] Eesti Rahva Muuseumi aastaraamat XXXIX [The Yearbook of the Estonian National Museum], pp. 167-186. 
Mikkor, Marika 2001. Muutuvast matusekombestikust linnas ja maal. [The Changing Funeral Tradition in Towns and Countryside.] In: Terje Anepaio (ed.) Eesti Rahva Muuseumi aastaraamat XLV [The Yearbook of the Estonian National Museum], pp. 103-146.

Must, Aadu 2012. Siber ja Eesti. Jalaraua kõlin. [Siberia and Estonia: The Rattle of Shackles.] Tartu: Tartu Ülikooli Kirjastus.

Paenurm, Peeter 1995. Luterliku matusetalituse kord ja praktika Eestis. [Liturgy and Practices of Lutheran Funerals.] Diploma work. Tallinn: EEKL Usuteaduste Instituut.

Pentikäinen, Juha 1990. Suomalaisen lähtö: Kirjoituksia pohjoisesta kuolemankulttuurista. [Finnish Death: Writings on Nordic Death Culture.] Suomalaisen Kirjallisuuden Seuran toimituksia 350. Helsinki: Suomalaisen Kirjallisuuden Seura.

Postimees 1899 = Eesti lastest Siberis. [About Estonian Children in Siberia.] Newspaper Postimees, No. 196, September 6, p. 1. Available at http://dea.nlib.ee/fullview.ph p?pid=s277970\&nid=3717\&frameset=1, last accessed on July 2, 2014 .

Ristolainen, Tiia 2004. Surmakultuuri suundumused tänapäeval: avalik ja privaatne. [Contemporary Tendencies in Death Culture: Public and Private.] Oppetatud Eesti Seltsi Aastaraamat 2002. [The Yearbook of the Estonian Learned Society.] Tartu: Õpetatud Eesti Selts, pp. 244-266.

Salve, Kristi 2000. Mõningaid tähelepanekuid tavanditoitudest: diferentseerimine piirkonniti ja üldistumine tavanditi. [Observations about Ritual Foods: Regional Differentiation and Generalisations.] In: Mare Kõiva (ed.) Sator: Artikleid usundi-ja kombeloost II. [Sator: Articles on Religion and Customs.] Tartu: EKM Rahvausundi ja meedia töörühm, pp. 121-140. Available at http://www.folklore. ee/rl/pubte/ee/sator/sator2/, last accessed on April 11, 2014.

Torp-Kõivupuu, Marju 2003. Surmakultuuri muutumine ajas: ajaloolise Võrumaa matusekombestiku näitel. [Changes in Death Culture in Time: On the Example of Historical Võru Region.] Tallinn: Tallinna Pedagoogikaülikooli Toimetised. Humaniora A 22.

Turner, Victor 1969. The Ritual Process: Structure and Anti-Structure. Chicago: Aldine. Viikberg, Jüri \& Vaba, Lembit 1984. Siberi põhjaeestlasi kõnetamas. [Conversations with North Estonians in Siberia.] Keel ja Kirjandus, No. 3, pp. 145-156.

Van Gennep, Arnold 1977 [1960]. The Rites of Passage. London: Routlege and Kegan Paul. Vuorela, Toivo 1977. Suomalainen kansankulttuuri. [Finnish Traditional Culture.] Porvoo \& Helsinki \& Juva: Werner Söderström Osakeyhtiö. 


\title{
SETO SINGING TRADITION IN SIBERIA: SONGS AND 'NON-SONGS'
}

\author{
Andreas Kalkun, Janika Oras ${ }^{1}$
}

\begin{abstract}
The article is based on fieldwork carried out in the 2000s among diasporic Setos living in Krasnoyarsk Krai, Russia, and discusses issues related to the singing tradition and identity of the Setos in this area. The article explores the ambivalent attitudes of the local singers towards their singing tradition and proposes a systematisation of the song tradition in the area into three groups Estonian songs, Russian songs, and Seto songs. The latter of the three represents the most archaic part of the Seto tradition, even though singers today no longer regard this part of the tradition as 'proper' songs, because of their improvisational and spontaneous nature. In addition to the ambivalence and confusion related to the identity and singing tradition, one can see conscious efforts in shaping identity politics and representing culture in Seto villages in Siberia. The best example of this is the Seto Museum and the choir active in Khaidak village. The generation of singers who are members of the choir today have discovered the old tradition in advanced age, but nevertheless find the singing of traditional songs highly significant. An important part of the contemporary identity politics of this tiny diasporic group is performing their exotic singing culture.
\end{abstract}

Keywords: diaspora, identity, Russian song, Seto song, Siberia, singing tradition, women's choirs

B: This is how we sing here; the tunes and all are the same. The same Seto people and the same Seto tunes. All these song tunes were brought back from Russia; our parents came here to sing and brought along their songs.

A: They came to live here.

B: Yes, came to live here and took the songs with them. [...]

A: They say that we are half-believers (polyvertsy). Our family comes from Audjasaare village [southeast Estonia]. ${ }^{2}$

My first field expedition to Seto villages in Siberia ${ }^{3}$ in July 2007 was replete with surprises. Although boasting considerable knowledge of the Seto culture in Estonia, I was astonished by this special amalgamation of the familiar and 
the unfamiliar. Although we seemingly spoke the same Seto language ${ }^{4}$, our occasional unconscious stumbling on some Russian or Estonian loan words gave away the differences in our linguistic and cultural background. While I had no problem joining the singing of some ancient ritual song or lyro-epic piece, I fell quiet, even though encouraged by the performers, when they picked up reportedly 'Estonian' folk songs to the tunes I had never heard before, or Russian folk songs that I was not familiar with either.

Some Estonian ethnologists who had carried out fieldwork in the area before had warned me that there was not much point in visiting the Setos in Siberia, because the old culture was on the verge of extinction. Indeed, the tangible and intangible culture of the Setos living in diaspora communities has transformed considerably over the past century, with much of the older tradition having disappeared or disappearing; however, we entertained no illusions of discovering anything congealed, musealised or untouched. It is inevitable, and not entirely tragic, that the tradition of the Setos in the diaspora has changed in time and is now different from what it was during their migration (see also Korb 2005). In Siberia we met communities who were aging, but some of them still spoke the Seto language and had a rich oral tradition. To our greatest surprise, we found a women's and children's choir active in Khaidak, the largest Seto village in Siberia. The choir fosters traditional choir singing and, like the Setos living in Estonia, the ones in Siberia greatly value the preservation of their song tradition. That being said, the attitudes of the Setos towards their song tradition were ambivalent: the spontaneous and improvisational Seto folk song, which is the most genuine part of the tradition, was not considered a 'proper' song, since it differed considerably from singing in Russian or Estonian style, in which the element of improvisation was not as central. The article attempts to delve further into the ambivalent attitudes of diaspora Setos towards their earlier song tradition. Since those knowledgeable about the tradition often emphasised in our conversations that the songs from the earlier layer of the tradition are not 'proper' songs, ${ }^{5}$ I have also used the local term 'non-songs' in this article. It should be noted, though, that I find this part of Seto song tradition by no means less important or non-existent.

The self-identity of the Setos in Siberia was equally fascinating. The informants had mostly heard from their parents and grandparents that they had migrated to Siberia from Rossiia ${ }^{6}$ (i.e., from the part of the Russian Empire to which the Seto region belonged at the time). At the same time, there was considerable confusion about the idea of motherland and the reasons why it was called Rossiia. Both the older and younger generations expressed similar confusion when referring to their ethnic identity. In the Soviet period, the Seto emigrants had 'Estonian' written as nationality in their passports, but many Setos perceived it as incorrect, since they did not speak Estonian and were 
aware of the clear difference between the Estonians and the Setos. Among the younger generation, the traditional identifying of oneself as Seto at home was equally confusing and brought no associations, because they had attended school in Siberia and had little knowledge of the Setos in Estonia. Many informants responded the researcher's question by saying, "You tell us who we are", and were pleased that ethnicity was not indicated in present-day passports of the Russian Federation. ${ }^{7}$

As pointed out in the article's motto, a conversation recorded in 1988, the self-identity of diaspora Setos is a fragile and contradictory mixture of internal and external representations. On the one hand, they are certain that they are 'the Seto people' and have 'Seto songs' and even remember the name of the village from which their (great-)grandparents once came. But, on the other hand, they say that they come from the ambiguous region of Rossiia, and call themselves disparagingly 'half-believers' by ethnicity. Curiously enough, the informants tended to associate their Seto identity with Seto songs, even to the degree that one informant, by a slip of the tongue, said that their parents came to sing there, instead of came to live there.

This ambivalence and confusion in the matters of identity persists even today, but there are also signs of emerging conscious efforts to construct one's identity politics and representation of culture, best demonstrated by the Seto Museum in the Khaidak village and the Seto choir active at the local community house. The choir makes appearances also elsewhere in the district and about once a year in the city of Krasnoyarsk, and is currently gaining popularity as a representative of exotic minority singing tradition.

In the following I will provide an overview of contemporary Seto song tradition in Siberia and explore issues of self-representation and -identity on the basis of observations and interviews made during the 2007, 2008 and 2012 field expeditions in the area. I have also made use of Igor Tõnurist's recordings from his 1987 and 1988 fieldwork expeditions in the same region. ${ }^{8}$

\section{WHO ARE WE? THE BACKGROUND OF THE IDENTITY PROBLEM}

In the late 19 th century and in the $1910 \mathrm{~s}$, many families ${ }^{9}$ emigrated from the overpopulated and poor Seto region at Lake Pskov to the then Yeniseiskii Gubernia, present-day Krasnoyarsk Krai. The Orthodox Christian Finno-Ugric Seto people were at the time designated in Estonian literature as Pskov or Pechersk Estonians (see Kreutzwald 1848; Hurt 1904a; Ustav 1908; Buck 1909). At the same time, ethnic Estonians did not see the Setos as their kinsfolk and thought 
of them as Russians, so that enlightened scholars of the humanities had to prove the kin ties to common Estonians even as late as at the turn of the century (Hurt 1989 [1904]: 145ff.). Russians, similarly, distanced themselves from the Setos and called them half-believers, alluding to the different interpretation of the Orthodox beliefs (see Kuutma 2006: 169ff.; Kalkun 2008; Honko et al. 2003). Since the Setos were illiterate at the time, there are no good sources to study the Seto self-identification of the period; however, there are some reports that in the 19th century they may have called themselves 'countryfolk'10, on the example of Estonians, or 'Russians', according to their religious affiliation (see Sarv 2000: 62), regardless of the fact that the Setos hardly spoke Russian at the time and mixed marriages of Estonians and Russians were extremely rare even as late as in the 1920s (Paas 1928).

The family names of the Setos who migrated to Siberia were derived from their patronymics, indicated in the documents, which means that upon settling in Siberia, the Setos with Orthodox names were given surnames like Matveev, Vasilev or Osipov. With the 1920 Tartu Peace Treaty, the Seto habitats at Lake Pskov became part of the Republic of Estonia and constituted Petseri (Pechory) County (see Raun 1991; also Raun 2007: 393). In 1921, the Setos were given Estonian surnames that Estonians would find pleasing to the ear (names in the Seto language were given less often, and Russian names were avoided altogether) and the integration of the Setos in the border areas and, according to the rhetoric of the time, the elimination of backwardness in the education and economic situation became the official policy of the Republic of Estonia. Alongside the changing of the language of education into Estonian, the administrative reform, the separation of mixed congregations and other reforms, the Setos of the region were rapidly modernised and Estonianised (Jääts 1998; Lõuna 2003).

As the emigration of the Setos fell into the period when they were illiterate, their contacts with relatives in the motherland remained problematic and soon disappeared entirely. Later, the correspondence was impeded by differences in education: since some were schooled in Russian and others in Estonian, they grew accustomed to writing the Seto language in either Cyrillic or Latin alphabet. By the 21st century, most Seto emigrants in Siberia had lost all contacts with their relatives in the motherland and only a few had memories of the last reciprocal visits that took place in the 1980s. Those who migrated to Siberia at the turn of the 20th century missed the changes that occurred in their country of birth, but the dramatic historical events began to change their lives as well. Men were mobilised to the First World War (1914-1918) and the Russian Civil War (1917-1922), the villages suffered from plundering, killings and wars. After the Bolsheviks' return to power, the entire religious 
life was banned and the new village churches in Khaidak, Perovo and Narva were closed down. All Estonian-language schools were also closed. While in the 1920s-1930s repressions it was the wealthier part of the population (e.g., the Setos who worked in gold mines) who suffered the most, the later repressions left almost no family untouched. The establishing of collective farms (kolkhozes) in the late 1930s disrupted the traditional way of life. Dispersed settlement and smaller Seto villages disappeared and gave way to new larger kolkhoz villages; part of the rural population urbanised, moving to larger cities and settlements. The Second World War emptied the villages from the remaining men and managing life in the villages became the responsibility of women and children. The villagers recall that life in the post-war period had been slightly better: collective farms flourished, people were paid in cash, but the younger generation continued to leave the countryside in search for better living and working conditions. The Seto villages of the present-day Krasnoyarsk Krai were gradually turned into Russian-speaking multi-ethnic villages with an aging and diminishing population due to the disappearance of collective farms and local employment and the 'youth drain'. Older women, living on state pension, now dominate in the villages.

\section{TWO GENERATIONS OF SINGERS}

Incidentally, in Seto villages both in Siberia and in the motherland, it is the women who uphold the singing tradition. Already at the end of the 19th century, collectors of folklore who visited the Seto region, wishing to record the singing of male bards, complained that they "had to be satisfied" with women's songs, which were still widely available at the time. ${ }^{11}$ In a patriarchal Seto village, traditionally homebound women remained less affected by modernisation and globalisation than their husbands. Therefore women held on to old traditional clothing, religious practices and lifestyle more conservatively, and also remained the main transmitters of the community's oral tradition. Also, the village choirs of the Soviet period were largely a female phenomenon. ${ }^{12}$ While the generation gap in the singing tradition of men occurred already before the wars and repressions, which further destroyed the traditional men's culture, the disruption in women's culture took place much later. The Seto women in Estonia, who sang in official village choirs in the Soviet period, usually wore traditional garments made by their grandmothers and remembered their songs. Seto women in Siberia abandoned traditional garments much earlier (see Piho 1994), but the women who sang in community house choirs claimed that they envisioned their grandmothers' performance style and thus even this official form of singing entailed a personally intimate and nostalgic aspect. 


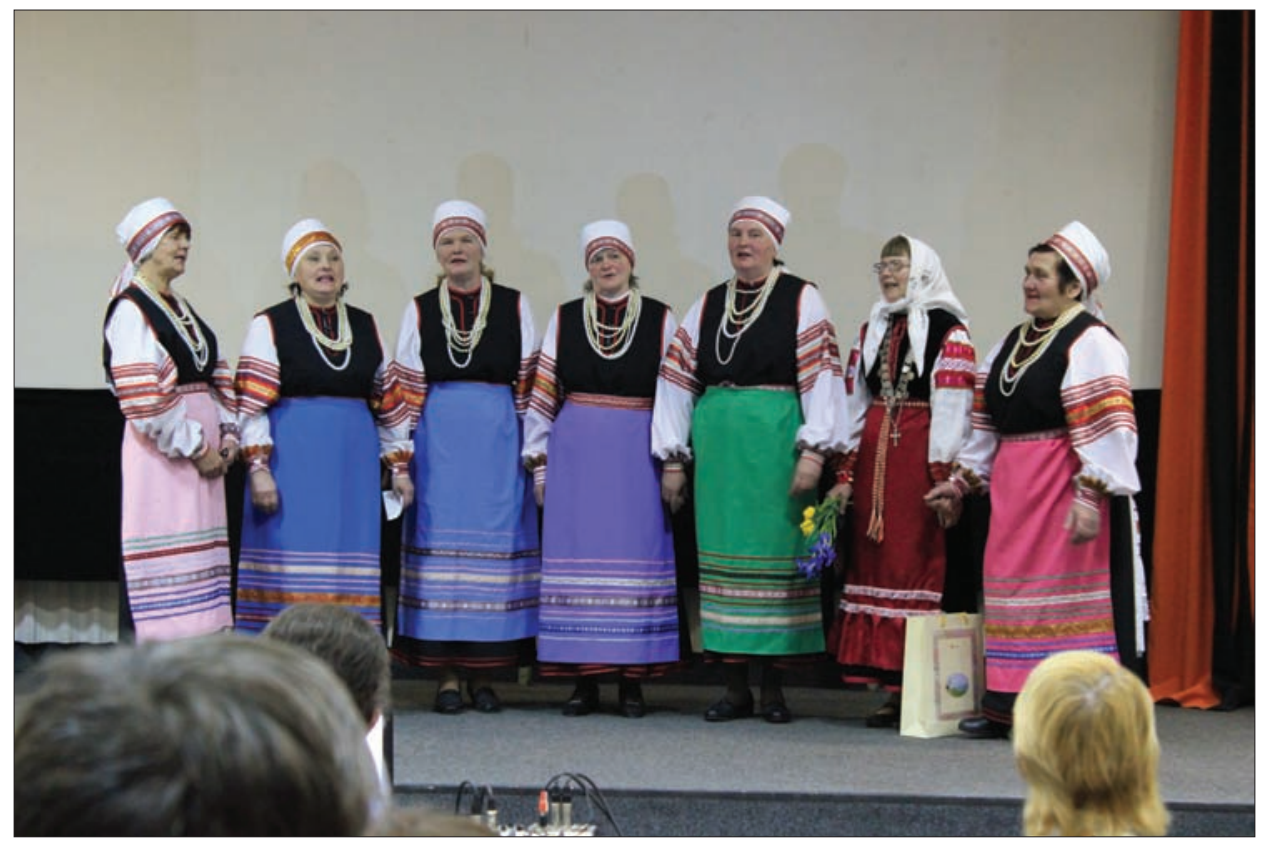

Figure 1. The Khaidak village choir Lill at the anniversary of the Krasnoyarsk Estonian Society. Lidia Ponomarchuk, Tanja Medetskaia, Olga Ivanova, Alidia Stepanova, Anna Kucherenko, Galina Evseeva and Maria Ossipova. Photograph by Andreas Kalkun 2012.

For Seto women in Siberia, singing in a group ${ }^{13}$ is a way to construct their identity both in the public and private spheres (cf. Olson \& Adonyeva 2012). On the one hand, singing is a public activity, which has been partly supported by the state through the local community house during and after the Soviet period. This official form of singing in a community house has been a source of emancipation for the women and has given them a chance to temporarily leave the domestic sphere or work on the collective farm, and participate in organised cultural life and travel. On the other hand, for the village women's community singing in a group represents an internal intimate form of communication, which has united different generations and has helped to preserve the tradition of the ethnic group and family with varying degrees of success at different times. Singing at home and among friends at feasts on calendar or other holidays has strengthened the sense of 'us' and associated a part of the repertoire with specific persons.

The singing of the Setos in Siberia is definitely not limited to the women in the community house choir and formal performances. During fieldwork I had a 
chance to take part in St. John's Day celebrations and some birthday celebrations in the village, at which singing in different languages and styles played a prominent role. There are a remarkable number of women in the Khaidak village who know Seto and Estonian songs and break out singing at the spur of the moment and at formal events. ${ }^{14}$ The most prominent representative of the lively singing tradition, however, is certainly the women's choir Lill (Flower), which comes together in Khaidak community house. The choir has been active for nearly twenty years, with varying degrees of intensity and a changing membership. Many local women have sung in the choir during its existence. Some have participated until their deaths, others have left the choir due to advanced age, some have sung in the choir for a long time, others for shorter periods. Over the period of our fieldwork, the choir had a relatively stable membership, with a leading group of three women, ${ }^{15}$ who used to work together as milkmaids before retirement. Other choir members were community house employees, who were younger than the leading trio, as well as some even younger women who participated less regularly. ${ }^{16}$

The three women who formed the choir's core belong to a generation who sang only Russian songs in their youth. Theirs was the first generation who was not educated in the Estonian language and had to adopt Russian, to the best of their abilities. This generation was also the first in which mixed marriages with Russians and moving away from the village became more common. ${ }^{17}$ As the women had heard Seto songs in their youth, sung by elderly villagers at home and public village events, they all had at least passive knowledge of the Seto singing style since the early age.

Maria P: Older women used to sing Seto songs when they got together at feasts.

Lidia K: When our mothers were young, nobody sung Russian songs. These became popular only when we went to school. We never sang Seto songs back then, when we were attending school. We didn't even know any. The older women sang these, but we hardly paid any attention.

Maria P: We are the post-war children, our teachers were Russians; the Seto / Estonian language was no longer taught at school.

Maria O: But our parents went to an Estonian-language school.

Lidia K: Well, some did, some didn't. My mother couldn't even write her own signature. ${ }^{18}$ (Khaidak village, July 2007)

The repertoire of this generation of women contained fewer songs related to family and calendar rituals, and more Soviet romances and popular songs learned from public media channels. When talking about their youth, the women agree that they used to sing Seto songs only "in jest". The women recalled that in 
these days Seto songs were sung while drinking, at small private parties and gatherings of women who worked together on the collective farm. At such events, singing was led by women who had learned Seto songs from their parents or who knew how to improvise on current day-to-day topics. The women did sing ancient songs in Seto style, but their generation had replaced the traditional ritual functions with entertainment purposes.

Lidia K: Maria P., Maria O. and I, we started to sing together. When we were invited to give concerts, we started to rehearse those Estonian and Seto songs as well. We never used to rehearse before; sometimes when drinking on the farm, my cousin, Timmo's Vera, was the lead singer. We usually sang when we were drinking. When we worked together with Anastasia, we sometimes sang these songs in jest, she knew them, we said davai, let's sing some Seto or Estonian song too. (Khaidak village, July 2008)

At the same time, for the women singing in the community house choir, the old ritual songs brought back memories of some former performances or the village women who used the same melodies. For example, a Shrovetide song, an Easter swinging song or a St. Catherine's Day song, but also songs sung at a Seto women's feast reminded them of earlier performance situations, so that singing these songs was also related to remembering the nostalgic lost times or past youth. The younger generation of singers admired the ability of older singers to improvise new lyrics on the go and found it particularly amusing that their mothers broke into singing at public village events even at an old age. ${ }^{19}$

The generation older than the choir leaders did not sing in the community house choir and thus their recollections about singing and performance situations were far more versatile and clearly different. ${ }^{20}$ They recalled songs sung when doing the household chores, laments at weddings and funerals, and mentioned song fragments that for some reason were significant enough to be remembered over dozens of years. Already in the material recorded in 1987 and 1988 in Khaidak village, people spoke about someone called Semmeni Olli ${ }^{21}$, who could sing so that "the village echoed back" when herding cattle. The younger generation of female singers spoke of the same thing in the late $2000 \mathrm{~s}$ and the woman herself agreed. Olga M. was one of the remarkable singers of the older generation, who had a vast repertoire, had never sung in an official choir, but readily sang alone or joined in spontaneously formed groups. In an interview, Olga M. regretted that she had not gone herding for a while and was starting to forget the song lyrics. Being a village herder at a rather old age, Olga M. used to sing traditional herding songs and other Seto songs, but by 2000 spontaneous singing during work in the open air had become a thing of the past in the village, and it happened, on rare occasions, only when drunk or old people were involved. 


\section{THREE SINGING STYLES}

The Setos in Siberia have incorporated songs and music of different origin into their repertoire. They have learned sentimental end-rhymed ballads in both southern and northern Estonian language from their south-Estonian neighbours, and adopted popular Russian songs from their Russian neighbours. ${ }^{22}$ As far as music, texts, language and particularly the level of stability are concerned, the end-rhymed and stanzaic 'Estonian' and Russian songs differ considerably from the 'Seto songs' - the songs in the special runo song style, which is characterised by a specific meter, figurative language, alliteration and variability of texts.

The Seto songs recorded in Siberia in 1987 and $1988^{23}$ suggest that the most predominant style at the time was the Seto song, seeing that the newer rhymed 'Estonian' song constitutes about one-tenth of the entire recorded song material. The complete absence of Russian-language songs in these recordings points to the selective criteria of the recording event: valuable tape capacity was, possibly deliberately, saved for what was considered the oldest and allegedly "more valuable" part of the singing tradition..$^{24}$ In the course of our fieldwork, we noticed that the representatives of the older generation, who did not sing in choirs, were less familiar with Russian songs and did not join in singing these in social situations. In the repertoire of women in the choir, however, Russian songs constituted almost a half, with the remaining half left to Estonian and Seto songs.

The different singing styles have certainly affected each other, but the singers whom we met during our 2007 and 2008 fieldwork trips perceived the difference between the singing styles very acutely. The Setos in Siberia, for example, believe that the fact that the singing style known as the Seto song allows a good singer to improvise new lyrics for each occasion and combine known 'words' 25 with new ones, while remaining true to traditional formulas and metrics, makes the Seto song completely different from Estonian and Russian songs.

The Seto song is based on the 8-syllable metre widely spread in the Baltic Finnish region (generally called regilaul, runo song or Kalevala-metric song) and follows a specific poetic model (see Example 1). The melodies of earlier Seto song types are based on a unique mode, i.e., the musical idiom is highly characteristic and very different from the diatonic scale of more recent music (see Pärtlas 1997; Pärtlas 2010; Ambrazevičius \& Pärtlas 2011). At the same time, the number of used melodies is limited. Group melodies are common (e.g., all harvest songs or travel songs are sung with the same melody). The Seto song is multipart and antiphonal. The lead singer, called sõnolinõ ('he/ she who knows the words'), says the verse that the choir repeats with variation 
and using polyphony. ${ }^{26}$ The special Seto multipart singing is based on the effect of the opposition of two voice parts. The Setos call the main melody and its singers torrõ ('good', 'nice') and the upper solo voice killõ ('sharp', 'shrill'). The torrõ part is usually heterophonic, though sometimes variations in the part are more planned, and then it is divided into 'torrõ' and 'lower torrõ'. The singer of killõ is expected to have a particularly loud, clear and rich singing voice so that it would stand out amongst the heterophony of the straggly torrõ part.

Killõ and torrõ in Seto songs are natural categories for the Setos. They are used to describe and measure also other polyphonic phenomena. In Siberia as well as in the Seto region in Estonia, it is common that the sopranos of Orthodox church choirs are called killõs. Although religious songs and Seto music are quite different in structure, as are the musical functions of soprano and killo parts (one is the melody voice and the other the accompanying voice, etc.), the same word is used to describe the two due to certain similar characteristics (it is the upper voice in a polyphonic choir, more intense than other voices, etc.). ${ }^{27}$ The Setos use the term killõ also for the upper voice in Russian songs. When singing Russian songs, the Setos seem to prefer a distinctive upper solo voice.

Maria V: Some sang killõ, and some sang torrõ. In the Russian songs too, one person sings killõ and others sing torrõ. It's the same in Seto songs, one woman sings killõ and others torrõ. (Khaidak village, July 2007)

When the choir of the Khaidak community house sang Russian songs, it was mostly only one woman who sang the upper voice. Apparently it was no coincidence that during the recording of songs in the Khaidak village in 2007 and 2008, Lidia K., the killõ of the older generation, always stopped singing the upper voice as soon as a younger woman took over, the part in the middle of the song, most probably because she did not wish to depart from the tradition that the upper voice is sung as solo part.

Here is another example, which proves that killõ and torrõ are natural categories for the Setos that are used to describe other similar phenomena. Olga M. was telling us about wolves, how differently they howl, and described their polyphonic howling. Some are killõs and some are torrõs, Olga said, and imitated their howling.

Olga M: When wolves howl, then one sings torrõ, the other killõ.

Andreas K: Is that so?

Olga M: Yes, they sing exactly like humans, one starts with a low wooww$w w$, the other repeats aayy-yy like killo. When there are four or five of them, they all howl as if singing, asking God to give them food. Asking where they are allowed to go. You shouldn't listen to those scabrous animals. (Khaidak village, August 2008) 
The area where the Setos had settled in Siberia was also inhabited by Protestant Estonians, who had emigrated from southern Estonia, constituted a majority in some villages, and soon assimilated among the Setos. Even though these emigrants spoke south-Estonian dialects, which are very similar to the Seto language, their music is very different from Seto songs (see Example 2). The Setos learned from them 'Estonian songs', the songs of the so-called newer singing style, which became popular in Estonia in the second half of the 19th century. The newer songs are end-rhymed and stanzaic, mostly sentimental ballads of borrowed origin (see Oras 2012; Rüütel 2012; Korb \& Peebo 1995). The melodies are not group melodies, like they are in Seto songs, but are associated with a specific text and are often of German or Russian origin. In the Estonian tradition, the songs were monophonic, but the Setos in Siberia sing them using polyphony, which is based mainly on Russian newer tradition (and the 19th-century Western music). Some of the sentimental songs sung by the Setos are also in the Estonian language. Siberian Setos do not usually speak Estonian, and thus the texts of these songs are often grammatically incorrect and obscure. Most of the newer Estonian songs known in Khaidak village are said to have come from Maria O.'s mother, and have been included in the repertoire of the community house choir through the mediation of her daughter. ${ }^{28}$

Besides Seto and Estonian songs, the repertoire of Siberian Setos also includes Russian songs (see Example 3). These are from different periods and of different origin: mostly popular songs from movies and the public media, local popular songs, and the approved repertoire of singing groups organised at community houses, learned through the mediation of cultural workers from songbooks published for the community houses or transmitted as oral lore (cf. Olson \& Adonyeva 2012: 134-135). People recall that many Russian songs have reached the villages through their relatives living in towns and cities. Maria P., for example, remembered that she learned the folk song Ia vstretil rozu ('I met a rose'; see Example 3) at family feasts in the Imbezh settlement, from her sisters who lived in Krasnoyarsk.

Maria P: Khoroshaia roza, semnadtsat' let ['Good rose, seventeen years']! Russian songs are all learned from the city anyway. My sisters used to visit us here, in Imbezh. They sang this Ia vstretil rozu, and so we started to sing it. The city people who had once left the village were visiting us in Imbezh. I wrote the songs down and we started to sing them. (Khaidak village, July 2007)

Most of the Russian songs in the repertoire of the community house choir come from younger women who also sing in the Russian choir of the Imbezh community house. 


\section{ON THE MEANING OF THE SONGS}

It cannot escape notice that among the Setos, groups of singers and the audience listen very attentively to the lyrics of Seto or Estonian songs and often discuss the meaning of the song after hearing it. More interesting or well-worded verses are repeated and admired; the audience wipe their eyes or laugh. The same happened only once or twice after Russian songs were performed. It is possible that Russian songs were considered to be commonly understood and thus their contents were not commented upon. It may also be that Russian songs are clearly perceived as 'songs', pure art, and are therefore considered less topical than Estonian or Seto songs, or less related to current affairs than, for example, Seto improvisations.

The new songs that the women sang with me were also discussed, and the most important verses were paraphrased in subsequent conversations. In 2007, I taught the women singing in the Lill choir a well-known Seto song about a moose killer. After singing it for the first time, the women kept saying, "Just think of it - he killed the moose!", and "I can't get it out of my mind how the moose fell down".

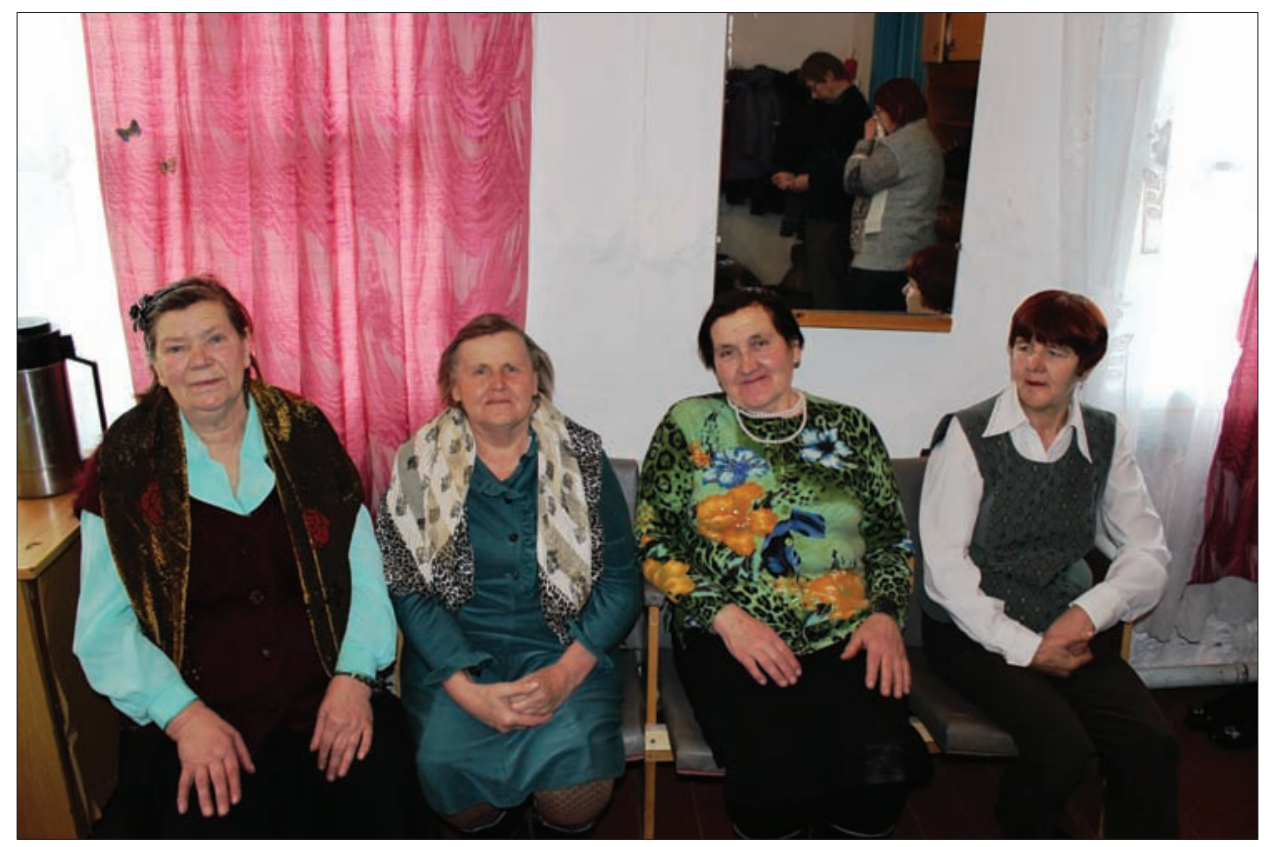

Figure 2. Community House of Khaidak village. Women before the recording of songs: Lidia Kondratieva, Maria Peterson, Maria Osipova, Lidia Ponomarchuk. Photograph by Andreas Kalkun 2012. 
The well-known Tütärlapsed, linnukesed ('Young girls, small birds'), an Estonian folk song of transitional form ${ }^{29}$, which contains several runo song motifs and is performed as a game song despite its rather tragic message, is known and loved in both Khaidak and Krestyanskii villages. The Setos in Siberia sing it in the south-Estonian dialect, so that the text is understood by everyone, unlike some other Estonian songs in transitional or even more recent form. In the song, young girls are warned against marrying a drunk, because a drunk beats his wife and children. The variants of the song sung by the Krestyanskii women and by Semyon's Olga end with a runo song motif, in which a woman is criticising her parents for not drowning her when she was a child. In 2007, during our first meeting with the Lill choir, the song prompted a dialogue, in which Alidia S. was surprised by the song's message, which advises girls against getting married.

Alidia S: Look, it says don't get married, but how can you not get married?! Maria O: Don't marry a drunk, a thug or a sluggard!

Alidia S: But how do you know if he turns out lazy or what he's like?! (Khaidak village, July 2007)

The Estonian song Üks rikka isa poeg ('Son of a wealthy man'), which Maria O. had learned from her mother, is most likely based on some north-Estonian text. While by now the song has been adapted to the south-Estonian dialect, it is still sung with several grammatical errors and inconsistencies. Some clearly north-Estonian forms have been contorted into the south-Estonian dialect, and vocal harmony has been added to the song. At the same time, some words representative of the north-Estonian language, such as nua instead of the Seto noun väidse ('knife') and südämes instead of the Seto süämeh ('in the heart') have been preserved. Regardless of the uneven text, the song's meaning is understood and the tragic story is found very touching. Our 2008 fieldwork revealed that the younger singers, who very likely might have a problem understanding all the Estonian and Seto song texts, are also fond of the tragic tale. For example, Tatiana M. requested that Maria O. sing specifically this song, "as it is so sad", and the performance elicited a conversation which demonstrated how the older generation of singers were emotionally moved by the song. At one point, though, they stopped delving into the sad storyline and abruptly changed the topic, as if wishing to get rid of such gloomy images, and proposed that we would sing something as well.

Lidia K: Is it over now?

Maria O: That's all!

Lidia K: What a sad song, isn't it?

Maria O: And you can't leave it unfinished. 
Lidia K: The groom also killed himself!

Maria O: They loved each other - the bride was poor, the groom was rich, and his father would not let him.

Lidia K: Well yes, so the groom fainted when the bride was lowered into the grave. Of course! Enough now! You sing now, we want to hear you sing! Sing us something, please!

(Khaidak village, July 2007)

Similarly, some songs reminded the singers of certain specific narratives that have probably been told among the group over and over. For example, after performing the song Mis nutad, minu süda? ('Why are you weeping, my heart?') Maria O. decided to mention that it was her grandmother's song about the time when young men were recruited into the army for 25 years. When her grandfather O. had gone off to war, his future wife was still in the cradle and the "old O." had given the child two pieces of candy, saying that when he returned, he would marry her. And so it had happened.

Some songs triggered memories of earlier performance situations. For example, in 2008, after Olga M. and Maria V. had finished singing an obscene song in Seto style about a hare startling a young maiden in the field, Maria V. admitted that she had almost forgotten the song and had remembered it only upon our request to sing it in 2007. Olga M., in turn, then recalled how they had once sung the song when they came back from the funeral of a woman called Hilda. Upon that, Maria V. remembered another time when they had sung it when returning from making silage. ${ }^{30}$

It is also very typical that singers remember the person who preferred to perform a particular song. Olga M., for example, associated several songs with specific people. She seemed to find the performances by men particularly remarkable: for example, after singing a song to the tune of a men's song, she mentioned it was performed by Turbin's Hilip. Also, when trying to recall a newer south-Estonian drinking song, Ma olen oma isa üksainukene vara ('I am my father's most precious treasure'), Olga M. spoke about the performance of a man called Kiisla's Timmo. Timmo had died already 50 years before, but the song always reminded Olga $M$. of his performance.

Olga M: Late Turbin's Hilip used to sing this song!

Maria V: Which song?

Olga M: Setokõnõ ['Seto']. You could sing the song until the next morning!

Maria V: You just had to 'pick' the words, from wherever you could.

Olga M: We had an aunt called Aleksandra, she could pick up any song at a wedding and keep on adding words until the end of the festivities.

She had many words. 
Maria V: Maria O.'s mother also had many words. Once we spent the night at her house, and she kept singing with the same melody the whole night, adding words about everything!

(Khaidak village, August 2008)

\section{SONGS AND ‘NON-SONGS’}

When singing Russian and Estonian songs, the women of the Khaidak village found it very important that none of the verses that were traditionally sung would be skipped during the performance. When a performer happened to skip a verse or a line, an apology was due. At a singing event, the older women of the Lill choir were displeased that Anna K., a younger singer, had left out a few known verses from a Russian song. So, when Anna finished the song, Lidia K. voiced her disapproval and sang the missing verse. After her, Maria P. sung another verse and Anna K. apologised for having skipped it. ${ }^{31}$

Apologising for skipping a verse or a line was also very common when newer Estonian songs or those of a transitional form were sung. Once, when Olga M., the singer who had the largest repertoire among the older generation, performed the game song Tütörlapsed, linnukesed ('Young girls, small birds') as a solo song, she found it necessary to apologise for leaving out a line or two. Suddenly, Maria V.'s husband Mikhail V. intervened in the conversation and snapped at the women, shouting that they should not sing it at all if they did not know the words, upon which his wife sang the previously left out verses.

Olga M: I'm already starting to forget the beginning. I need to hum a little sometimes. Now I'm not even going herding anymore.

Mikhail V: You've left out half the song. If you can't sing, don't do it at all!

Olga M: Come, help me with the lead!

Maria V: "Baked bread from alder leaves, made porridge from willow bark."

Olga M: Oh, I have forgotten all that!

(Khaidak village, August 2008)

The interviewed Seto women in Siberia were often quick to name the Estonian and Russian songs they knew, but became confused when asked to talk about Seto songs. Since improvisation was often the first thing that came to their minds when talking about Seto songs, they agreed that the songs were rather obscure, saying that "those who can, sing about what they see or what comes to their mind". When referring to Seto songs, Siberian Setos used words related to the natural, commonplace or trivial. For example, in 2007, Nadezhda 
K. (b. 1937) and Anna M. (b. 1938) from Bulatnovka discussed Seto, Estonian and Russian songs. The conversation revealed that Nadezhda's mother was a Seto - as is often the case among Siberian Setos, she apologetically added that they were not "real Estonians, but Setos" - and liked to sing Estonian songs. A question about Seto songs, however, confused the women. Nadezhda K. said that Estonians as if had their songs, but the Setos did not, they sochinyali, ${ }^{32}$ sang about what they saw around them. The women found the melodies of Seto songs quite commonplace and ordinary, claiming that there was no special melody to them, simply singing. ${ }^{33}$

Andreas K: So your mother was a great singer?

Nadezhda K: Yes, my mother could sing all the Estonian songs. She wasn't pure Estonian, she was a Seto, but knew all the Estonian songs. They sang beautifully. My sister too, they knew the songs very well.

Andreas K: But could she sing Seto songs as well?

Nadezhda K: There aren't many of these Seto songs, there are only Estonian songs. When singing a Seto song, one sochinyaet, improvises about what she sees, sings the lead. But Estonian songs were different.

Andreas K: What were the Seto melodies like?

Nadezhda K: There was no melody or anything, just singing. Estonian songs have words that are taken straight from real life. They sang about how life used to be. The Estonian songs were very good.

(Bulatnovka village, July 2007)

When we first met the Khaidak village choir in 2007, Maria P. welcomed us with an improvisation to demonstrate what a 'real' Seto song was like. A Seto improvisation always reflects the audience and the performance context, so all members of our fieldwork team - Anu Korb, Marge Laast and me - were put in the song.

\section{Maria P:}

Eestist tulliva’ külälise’.

Tops õks viidi, tõnõ tuudi, katsipooli kannõti.

Anukõnõ, tsidśakõnõ,

Margo, meelimaŕakõnõ,

Andreas, kuku velekene!

Sedä-ks aigo ammu oodi, ammu-ks oodi, kavva kai.

[We have guests from Estonia

A cup was taken away, 
Another put on the table,

Carried by two men.

Dear Anu, my sister,

Margo, my beautiful,

Andreas, dear brother!

We have long been waiting for this moment

Long been waiting, long expecting.]

(Khaidak village, July 2007)

We had a similar encounter during the 2008 fieldwork. This time, Olga M., who represents the older generation of singers and had never sung in an official choir but was known for her brilliant singing skills, was also present. Maria P., who was eager to have us experience the 'real' Seto song, asked Olga M. to show how Seto singers sing about what they see and think; for example, with a dedication song to me and Anu Korb. The elderly woman at first did not understand what was asked of her, but then sang an improvisation to the guests employing the Tulevik teadmata ('Future unknown') and other runo song motifs. ${ }^{34}$ However, Maria P. was not quite content with the song, because it was too poetic and not specific enough, and asked Olga M. to create a song about, for example, how Andreas and Anu took a plane to Krasnoyarsk, then from there a bus to Khaidak and then walked to Bulatnovka village. ${ }^{35}$ Maria P. considered it necessary to tell us about the spontaneity of Seto songs and their relation to time and place even after an Estonian song was performed.

Maria P: Well, Seto people also have this thing - that I just saw you and I'm going to sing about you right now. A Russian or an Estonian song has to be sung the way they are, but this is how we do it: for example, I saw you, and now I will sing about it. [...] What you are like determines the song. (Khaidak village, July 2007)

Discussions about the "real" Seto song often evoked memories about singing at weddings. Praising or taunting someone at a wedding was given as an example of the flexibility and improvisational nature of the Seto song. Lidia K., killõ of the Lill choir, also differentiated between a 'proper' song and spontaneous improvisation. The wedding lament is an example of an improvised Seto song.

Andreas K: And this was also a wedding song?

Lidia K: It was simply sung anywhere, in village streets. This one was a real song, but the wedding laments and other such are improvised with own words. In the old days there were many people who could do this, but nowadays there are not many who can create these real Seto songs. (Khaidak village, August 2008) 
While Seto songs were generally characterised as being made up, often using the Russian verb sochinit', Russian and Estonian songs are known to be fixed, sung correctly, po poriadku. Compared to other singing styles, Seto songs were also typically seen as very long, endless and amorphous.

Maria O: But these Estonian songs are indeed long. Very long. When you start singing a Seto song, for example, Mari-sori, which is a very dirty song, you start singing it in the evening and you can keep singing until the next morning. It's very long!

Lidia K: But that song is not improvised, it's sung po poriadku. (Khaidak village, July 2007)

Vasili K: You see, a Seto song never ends; you keep looking around and sing on!

Lidia K: Yes, but then you need someone who knows the words, who sings the lead. When I start singing the lead and the choir joins in and starts interfering, I get it all mixed up.

(Khaidak village, July 2007)

Aside from that, other figures of speech were used to characterise the length and unique creative process of a Seto song. Olga M., for example, talked about the length of her herding song and how the text was not fixed, claiming that she simply had to 'pick' the words when singing.

Andreas K: But when you are with the herd, what do you do then? Do you hoot as well?

Olga M: No, I don't hoot, there I'm singing the herding song for a while.

Andreas K: What's the herding song like?

Olga M: The herding song? It's long, however you want to sing it, you pick the words.

Andreas K: But how?

Olga M: I simply start picking.

(Khaidak village, August 2008)

I found quite similar comments and metaphors about creating the Seto song in the recordings made in the villages at the end of the 1980s. The women of the Khaidak village performed to the folklore collectors (Igor Tõnurist, Mare Piho, and Õie Sarv) an improvisation to a men's tune and the lead singer and a member of the chorus then discussed the idiosyncrasy of the Seto singing style. Again, the informants emphasised that the Seto song was not a ready-made song to be repeated over and over again, but that a proficient singer could continue the song almost indefinitely. 
A: That's enough!

B: It is like whenever you know the word, you just say it!

A: It's not specifically that you sing like this...

B: ... or continue like that... it's how the singer says it.

A: When you pick up the song, it never ends.

B: A Seto song knows no bounds.

(Khaidak village, September 1987)

The improvisational nature of the Seto song and the possibility of endlessly creating the song was also discussed after the performance of a mock wedding lament. The singer disrupted the song and expressed regret, saying: "It does go on, but that's all I can remember". Upon that, a co-singer, who evidently hoped it would not continue, made a derisive comment, "Hasn't the song already lasted for a week?"36

\section{IMPROVISATION IN THE SETO SONG: PERIPHERY OR CORE OF THE TRADITION?}

In the early history of Estonian folklore studies, cultural heritage was often approached as something homogeneous and ready-made, waiting to be collected. At the same time, little thought was given to how the heritage had been constructed and created ${ }^{37}$ and which ideologies and politics it had supported. Our contemporary views of the Seto singing tradition are largely based on what collectors, publishers and researchers of Seto songs have once created. Immediate fieldwork experience, however, may reveal how simplified and stagnant this knowledge is and how the songs recorded, stored in the archives and published in anthologies represent only a small selection compared to the variability, dynamicity, divergence and ambiguity of the living tradition. Texts constructed by researchers, fitted to genres, and isolated from the context and performance, give only a vague idea of what live performance could have been like (see Bauman 1988 [1986]: 3ff.; Briggs 1988: 353ff.). A researcher's and a performer's understanding of the tradition and its nature, salience and value are often widely different.

The interviews conducted with the Setos in the diaspora revealed a radical emphasis on the improvisational nature of the older singing culture. The Seto song was characterised as something highly natural or spontaneous, created on the spot. At the same time, the unique improvisational nature of the song led many to regard the singing style as something commonplace or insignificant compared to Russian or Estonian songs. Many of my informants admitted that 
they did not consider the Seto song a 'proper' song. The choir of the Khaidak community house preferred to sing Seto songs outside formal performance situations: for example, at the choir's formal performances in 2012 these songs were not performed, but they were sung later in more informal situations, while sitting together at dinner table.

Seto improvisations are typical in that they deal with current or autobiographical matters. Researchers searching for ancient songs that would conform to established type ${ }^{38}$ have regarded them less valuable than the songs in which the aspect of 'creation' is overshadowed by 'recollection' or 'mediation'. ${ }^{9}$ Folklorists have thus preferred to collect songs in which the performer mediates the old tradition and in which his or her own person and creative nature remains hidden. Regardless of the speculations and errors of researchers, the Setos both in Siberia and Estonia have considered the skill of creating new songs and spontaneous improvisation one of the most important criteria for assessing a singer's creative ability and knowledge of the traditional singing style. ${ }^{40}$ One of the major events at the annual celebration of the Seto Kingdom Day $^{41}$ is the sõnolisõ contest, in which the best singers compete in creating the finest (i.e., the most topical, but at the same time the most traditional) song on a given topic within a given time (see Sarv 1997; Kuutma 2005: 230). In 2009, on the initiative of the Setos in Estonia, Seto polyphonic singing was inscribed on UNESCO's Representative List of the Intangible Cultural Heritage of Humanity. To be inscribed on the list, several Seto organisations cooperated in writing a comprehensive overview of the Seto singing tradition. Improvisational skills were mentioned already in the first introductory paragraph as a highly characteristic feature.

Seto leelo (literally 'song') denotes a traditional singing style, repertoire and culture of the Setos. Its poetic structure and certain musical features are estimated to date back a millennium. Its text and metrics present a local version of the Baltic-Finnic runo song tradition; leelo is characterised by an alternation of solo and choral parts. A lead singer performs a verse line; the choir joins in for the last syllables, and repeats the whole line. Based on their knowledge of traditional poetic formulae, the rules of the poetic and metric system, Seto lead singers create new lyrics for each particular occasion. They perform also texts learnt from previous great performers, but the skill to compose lyrics is essential for a renowned lead singer (Seto leelo 2009).

At the same time, modern Seto singing culture in Estonia reveals a tension between the fixed-form song and improvisation. Leaders of Seto choirs today accuse each other of reciprocal (often secret) recording of other choir's songs 
and learning the songs of 'others'. Great female singers intently listen to and 'recognise' their 'words' in the songs of other singers and are full of contempt towards the singers who do not have their own words and who compose songs by taking "one line from here, another from there". Some Seto choirs have even declared their refusal to sing "the songs of others", because they consider it immoral (see Laanemets 2012). ${ }^{42}$ Aside from that, contradictory preferences that value the fixed form could be observed. In the debates and discussions about the future of the Seto singing style, some Seto choirs have demanded that specific, highly valued songs, which are generally associated with specific singers, should "stay as they are", so that no one could "change and corrupt" them. Despite the fact that such popular songs have acquired a certain fixed form, because they are published on records and tapes, they are still known, in different versions, in orally transmitted folklore (see Kalkun 2011: 42). Indeed, while the younger generation of diasporic Seto singers value spontaneous improvisation as a skill, they also avoid practising it. Improvisations, they believe, are too commonplace, even vulgar, their texts too long and the melody uninteresting or lacking in musical qualities.

\section{TENTATIVE CONCLUSIONS: DISRUPTIONS AND CONTINUATIONS}

While ever since the 1920s, the Setos in Estonia have been taught that their song tradition is part of an ancient, valuable and authentic Baltic-Finnic song tradition, the Setos in the diaspora have lived in a completely different sphere of information and have not heard of the knowledge, accumulated by folklorists and used by the Setos in Estonia to strengthen their identity and culture. When local cultural workers and state-supported community houses started to provide minority groups with resources to perform their traditional songs, ${ }^{43}$ the generation who sang in the community house choir already had a rather vague idea about their tradition and its nature. They were more than willing to comply with the foreign cultural workers' wishes and present their 'authentic' singing tradition, but at the same time they had alienated from certain elements in their musical culture (its improvisational nature, ancient modes), which were particularly characteristic of the earlier part of the tradition. The conscious or subconscious wish to assimilate to the dominant singing culture on the one hand, and to present their own unique singing culture on the other, has created an interesting situation in Seto diaspora communities, in which hybrid forms emerge, which domesticate foreign elements and adapt genuine ones. Towards the end of the 1980s, modes characteristic of early Seto music (for traces of 
earlier modes, see the notation in Example 1) had become rarer owing to the influence of music in diatonic scale. ${ }^{44}$ The number of singers who know how to improvise song texts in the old style has fallen significantly. Improvised songs are not suitable for performing on stage; the community house choir, for example, prefers to perform songs they have sung many times to avoid any inaccuracies on stage. The early Seto singing tradition is thus represented in today's repertoire of the Khaidak village choir by newer rhymed songs with fixed texts, modified to the Seto culture, and with melodies of a broader scale and mostly borrowed origin.

The Seto singing style in Siberia is an interesting, yet odd, combination of stability and changeability, the old and the new. The songs and tunes of Estonians, Setos and Russians have merged into a unique whole. Younger generations

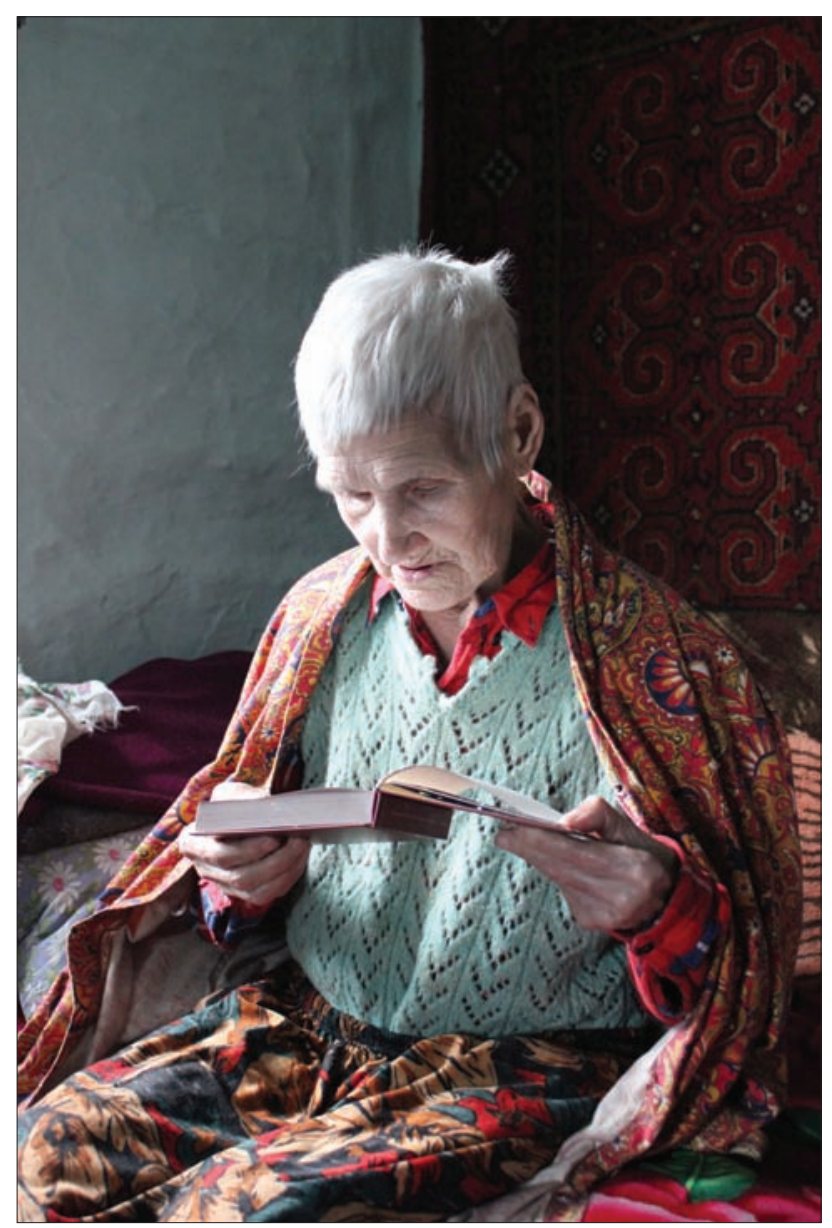

Figure 3. Maria Vasileva of the older generation of singers is examining the edition "Songs of Siberian Seto". Photograph by Andreas Kalkun 2012. 
re-interpret their song lore and issues related to identity. The singing tradition of the Setos in Siberia shows a clear disruption within the generation of the Soviet period, who felt uncomfortable singing songs in the Seto language in their youth. As the generation is aging and has found a new nostalgia towards their ethnic culture, but also as a response to encouragement from the outside to foster their own culture, they are developing a new consciousness of their ethnic group and its unique tradition.

As the communities of Seto villages in Siberia are becoming increasingly multi-ethnic and mixed marriages more commonplace, we can no longer speak about a homogeneous community based on an ethnicity or descent, but these are imaginary communities that modify and perform their ancient, though still existing tradition (see Anderson 1994 [1983]). The new generations of Seto singers in these Siberian villages adapt the singing culture to fit their needs and redefine the tradition based on their views of what is 'proper' music and song. The fact that the line drawn between songs and 'non-songs' in contemporary Seto singing community in Siberia leaves the earlier part of the tradition to the category of 'non-songs' is probably caused by the disruption inside the culture, but also by the endeavours of cultural workers and the need to present own culture on stage.

Despite the fact that the Seto singing tradition has lost its ancient ritual functions and its most unique part has been marginalised among the Seto communities in Siberia, even the singing, which today is increasingly mainly heard in community houses and museums, serves a function of supporting identity and symbolically constructing the community (see Tarkka 2005: 388). In this light, as long as these women keep on singing what they call the 'Seto song', in whatever form, in the community house or at private gatherings, they continue to fulfil a new ritual function - namely, constructing their cultural heritage and identity. Indeed, the concepts of 'Seto people' and 'Seto song' may entail different meanings at different times, but as long as there is still discussion about the nature of Seto songs and the categories of songs and non-songs, the efforts to forge one's identity and singing tradition continue.

The community of Seto singers in Siberia is tiny and very susceptible to external influences. During our fieldwork we experienced their immense interest in relatives living in Estonia and their songs. Many women whom I met in Siberia asked me to teach them songs that are sung in Estonia, and to send them recordings of Seto songs. Only time will tell how the Seto singing culture in Siberia can change after their songs are published. In 2012, the Estonian Folklore Archives published an anthology of Seto songs in Siberia (see Kalkun \& Korb 2012). When we introduced the anthology in Krasnoyarsk in 2012, the Khaidak village choir had increased by a couple of members, who in 2008 had 
told us that they did not know any Seto songs. By then, several older Seto singers had become bedridden and stopped singing. The future of songs and non-songs and those who sing them therefore remains to be seen.

\section{COMMENTS TO THE MUSICAL NOTES OF THE SONGS}

\section{Example 1. Seto song}

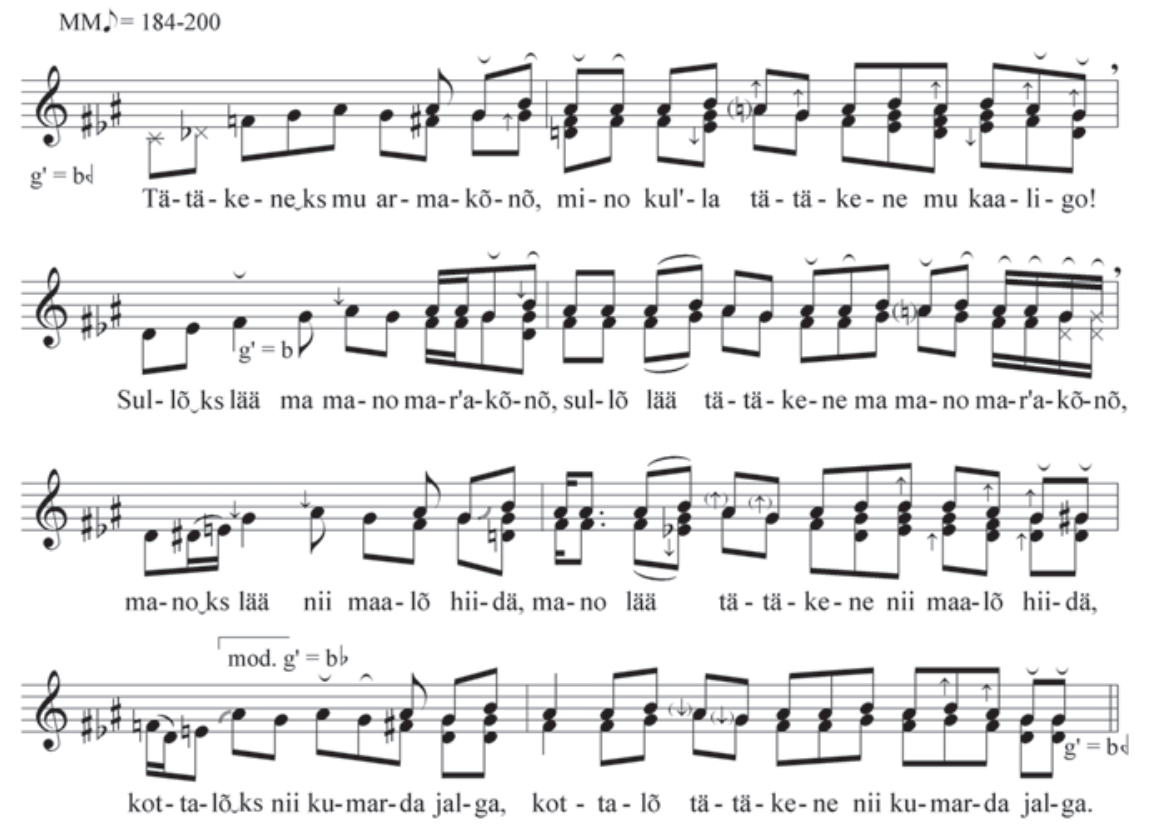

The bridal lament represents the earlier Seto multipart singing style. The bride traditionally sings the lead, while the chorus part is sung by podruskid, bridesmaids, in a bridal lament. The singing is accompanied by rhythmic bows. In the lament, the bride addresses her father, asking why she has been given 
away, while she is needed to plough the field. She fears that life in her husband's home will be hard, and contemplates whether she should drown herself instead.

The lament, recorded in 1988, is performed by elderly women in the Khaidak village choir. The notation presents the first four verses of the 34 -verse lament. The chorus reiterates the verse sung by the lead singer, inserting the address formula tätäkene ('dear father') in the middle of the verse. In the earlier Seto singing tradition, as in many Baltic-Finnic runo song regions, the chorus joins the lead singer before the end of the line, in this case, on the third to the last syllable. The end notes of the chorus part are generally lively and accelerated, and are followed by the lead singer with no pause in between. Typically to the songs of an earlier style, the syllabic melody is fitted to the text: the rhythm and melodic contour change according to the verse structure (e.g., the end of the chorus part varies, having 4-7 syllables after the added addressing formula).

In musical terms, the unique feature of the most archaic Seto tunes is a rare scale, in which semitone intervals alternate with three semitone intervals (D-Eb-F\#-G-A\#-B). The harmonic system is based on two opposed complexes of scale notes, consisting of four-semitone intervals (D-F\#-A\# and Eb-G-B) (e.g., Pärtlas 2010; Ambrazevičius \& Pärtlas 2011). Here the upper solo part killõ uses the three upper notes of the scale, while the lower torrõ part is sung heterophonically and up to three notes may be sung simultaneously. The performance reveals the tendency of singing the second tone of the scale (Eb) at a lower pitch and, regardless of the harmony, the lower note usually sounds approximately like $\mathrm{D}$, which has also been noticed in the performances of some other Seto choirs (e.g., Ambrazevičius \& Pärtlas 2011: 4; Särg 2012). The lament is sung using the chest voice in the speech register, and the pitch of scale notes varies considerably. During the singing, the pitch gradually rises, and the marking mode indicates a typical device in Seto singing called kergütamine ('facilitation') - an abrupt modulation by lowering the pitch about a semitone. The additional markings $\checkmark$ and $\neg$ show slight shortening and lengthening of the note (sometimes depending on the syllable length), while $\uparrow$ and $\downarrow$ show the raising or lowering the note by less than a semitone. 


\section{Example 2. Estonian song}

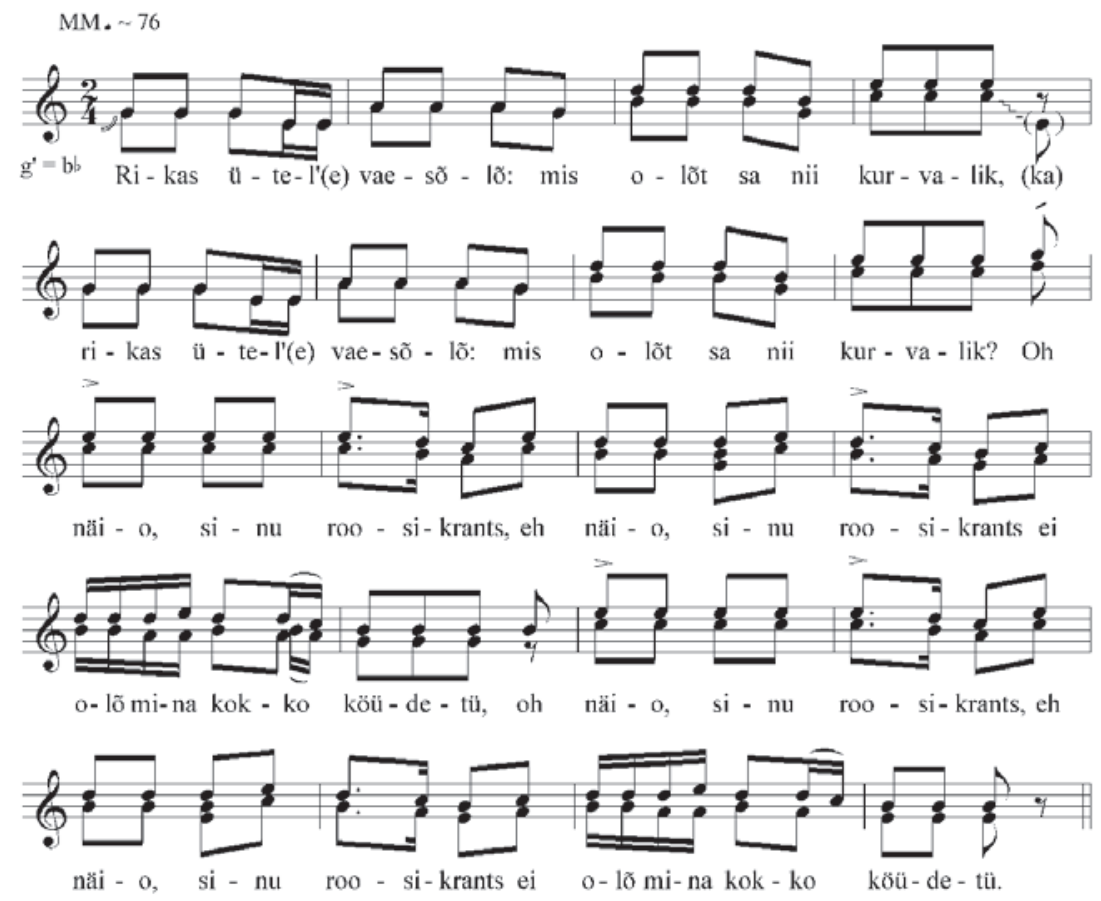

The Estonian love song represents the so-called newer, end-rhymed and stanzaic singing style, which became very popular in Estonia at the end of the 19th century. In the song, performed in 2007 by the Khaidak village choir, two maidens discover that they are in love with the same young man. The man decides to give them both up and chooses a third girl. In Estonia, the song is known in the areas neighbouring the Seto region as a game song. The song's content is acted out, or singers walk in a circle and dance during the chorus Oh neiu, sinu roosikrants ('Oh, maiden, your chaplet of roses') (see Rüütel 1983: 128-135).

The notation features the second verse and the refrain of the 7-verse song. The song is sung in chorus without a lead part, as is characteristic of newer Estonian and Seto singing styles. The upper solo voice, which functions as the accompanying voice, splits from the lead voice in the verse part in the middle of 
the line. While singing in the earlier and newer style in the Estonian tradition is mostly monophonic, this performance demonstrates a stable multipart singing. The dominant movement is in parallel thirds, which matches the functional harmony characteristic of the style. Comparison of this Seto version with the melody known in Estonia reveals that in this version the melody is sung by the lower voice, while in the refrain part the main melody is sung by the upper voice (although the Estonian song's tune ends with a descent D-C-B-A-G). Such multipart rendition may be explained with an aim to follow the harmony of the melody.

It is notable that the cadences of the Estonian and Russian song (Example 3) are different from each other. While Russian songs typically have the cadence in a unison or octave, the Estonian song has a major third in the cadence. In this Seto version, the use of the third in the cadence can be linked to the earlier Seto multipart singing style. Such imperfect cadence is also characteristic of songs of Estonian emigrants in Siberia, in which a unique kind of multipart singing has developed under the impact of the Russian tradition (cf. Pärtlas 1995).

\section{Example 3. Russian song}

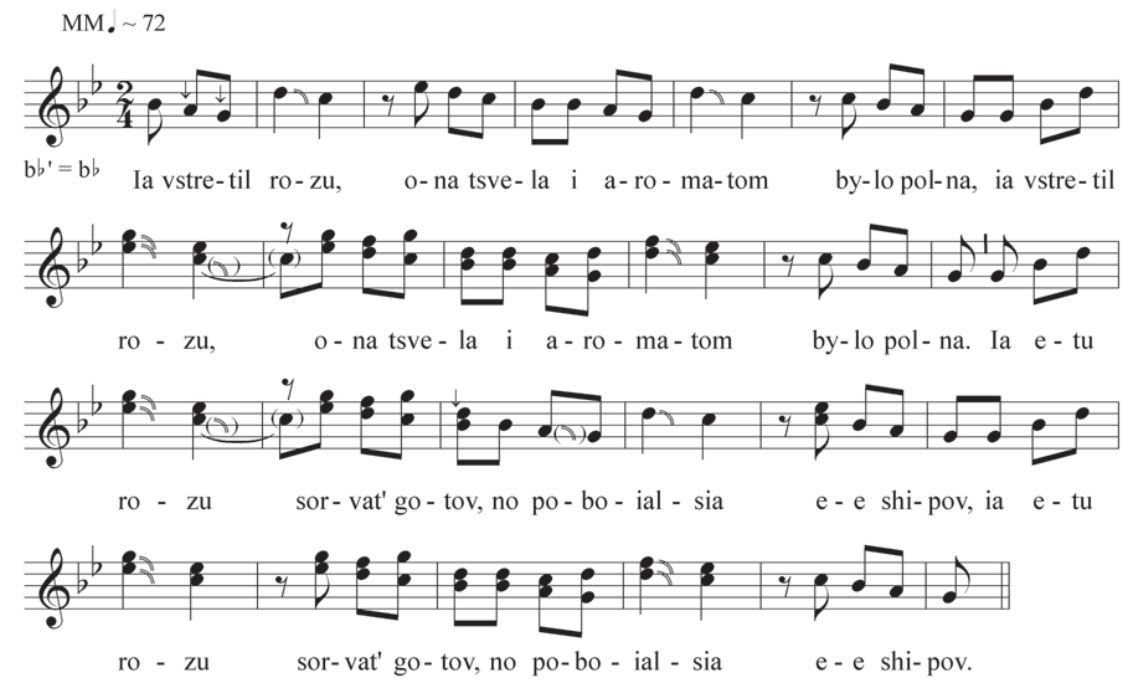


The song in the Russian language represents a newer Russian urban song style and was recorded in 2007 from the Khaidak village choir. The song is built upon the imagery of rose. The singer dares not to touch the rose, but others strip it of its beauty. In the end, young men are advised not to touch 17-yearold roses. This song may originate from the 1960s-1970s, according to online song anthologies (see a-pesni; Antologiia; Dvorovye romansy). The performers learned the song from one of the singer's relatives who lives in town.

The notation presents two verses of the 6-verse song. The song is sung in chorus, the lower main voice is joined by an upper accompanying voice sung by one singer. It is difficult to distinguish whether the accompanying voice occasionally joins in the unison or makes a pause in singing. The version of Khaidak women is distinct in that from the beginning of the second verse they only repeat the latter half of the melody. The song is typical for the newer urban song style, in which Western influences are combined with specific features of the 'Russian style', such as the natural minor, plagality and the characteristic multipart singing (e.g., Shchurov 2007: 276-279).

\section{ACKNOWLEDGEMENTS}

The study is carried out within the framework of the research project IUT22-4, "Folklore in the Process of Cultural Communication: Ideologies and Communities", financed by the Estonian Ministry of Science and Education.

\section{NOTES}

1 The notations of the songs and comments are by Janika Oras, who also participated in writing the chapter 'Three singing styles'. We would also like to thank ethnomusicologist Žanna Pärtlas for her suggestions regarding Russian singing tradition.

${ }^{2}$ Khaidak village choir, audio tape recorded by Igor Tõnurist, September 1987.

3 Andreas Kalkun participated in field expeditions to the Seto villages in Krasnoyarsk Krai, organised by the Estonian Folklore Archives, in 2007, 2008 and 2012. The fieldwork covered the largest Seto villages in the diaspora, Khaidak and Novaya Pechora, but also much smaller villages and settlements with Seto population (Bulatnovka, Krestyanskii, Kiyai, Ostrovki, Narva, Partizansk) in the Partizanskii, Manskii and Rybinskii districts and the city of Krasnoyarsk. Khaidak village in the Partizanskii district has the largest Seto population, among whom the cultural heritage has been preserved the longest. Anu Korb, folklore researcher at the Estonian Folklore Archives, was his main fieldwork partner; in 2007 they were accompanied by Marge Laast, in 2008 by Tiit Sibul and Astrid Tuisk, and in 2012 by Eva Sepping and Vahur Laiapea. 
4 The language spoken in the Seto region has been identified as the eastern variety of Võro dialect (e.g. Keem 1997) and as a separate dialect (Pajusalu 2000; Pajusalu et al. 2009). Be that as it may, the Seto language shares common features with the eastern group of the Võro language (Keem 1997; Keem \& Käsi 2002). The Setos themselves claim that they speak the Seto language and find it different from the varieties spoken elsewhere in southern Estonia. When the Seto language is treated as a variety of the Võro language, the Setos in Estonia often take it as an insult or a threat to their linguistic autonomy (Juhkason et al. 2012). This is the reason why henceforth I have chosen to use the term 'Seto language' in the article. Also, I prefer to use the ethnonym 'Seto' instead of the form 'Setu', which is common in standard Estonian, since the Setos themselves consider the latter a disparaging term.

5 Estonian song tradition has also been characterised by the fact that the performers have not considered the melodies of earlier type as proper tunes or distinguished between them (see Rüütel 1998).

${ }^{6}$ Derived from the Russian word for Russia (Rossiia).

7 This confusion regarding ethnic identity has been observed also among other groups that have migrated to Siberia. For example, the Protestant Prussians, who had emigrated to Poland (the present-day territory of Ukraine) in the 17th century, had adopted the Polish language by the 18th century, and had migrated to the vicinity of Irkutsk in Siberia in the early 20th century, refer to themselves as the Dutch (see Muszkalska \& Polak 2009).

8 Igor Tõnurist took part in the field expeditions organised by Mare Piho, an ethnologist with Seto roots, with the Estonian National Museum. Õie Sarv, also of Seto origin, participated in the expedition of 1988.

9 The exact number of emigrants is unknown, but August Nigol (1918: 55), who has studied Estonian settlements abroad, claims that over 5,000 Setos settled in Siberia.

${ }^{10}$ Before the ethnic identification eestlased was more widely adopted, Estonians also used to refer to themselves as 'countryfolk' or 'countrymen' (see Kuutma 2006: 169).

${ }^{11}$ On the folklorists' particular preference of men's songs in this period, see Kalkun 2011: 141.

12 The same held true for Seto choirs in Estonia (see Kalkun 2004). While by the 1990s village folk groups also elsewhere in the Russian Federation were predominantly allfemale, some men sang in women's groups only in the Cossacks' and Old Believers' regions (see Olson \& Adonyeva 2012: 137).

${ }^{13}$ I have also studied social groups of Seto women singing in folk and church choirs, with a focus on interpersonal relations and conflicts in these groups stemming from different preferences of song styles, etc. (see Kalkun 2004; Kalkun \& Ojamaa 2009). More recently, Liisi Laanemets (2012) has studied a choir with Seto roots, active in the city, and its identity performance.

14 The majority of songs that were collected during fieldwork come from Khaidak village. There are certainly singers elsewhere as well; for example, in 2007 the women of Krestyanskii village came together upon our wish and recalled and sang their songs. 
${ }^{15}$ In this article I refer to all my informants by the first name and the initial of the surname. The ages of the informants are given in parentheses at first mention. The choir leaders were Maria O. (b. 1942), Maria P. (1941-2013) and Lidia K. (b. 1939). During the recording sessions of 2007, one of the singers who happened to sing to us was Alidia S. (b. 1943), who had become a permanent member of the choir in 2012, when the choir's core had become smaller.

16 The singers junior to the leading trio, Anna K. (b. 1952) and Tatyana M. (b. 1961), represent the younger generation of Seto singers in this article.

${ }^{17}$ Of the three leaders of the choir, one married a local Estonian, others married Seto men. Only one of the children of the core group women is still living in the village, others have moved elsewhere, to larger cities and settlements. All of their children have married Russians.

${ }^{18}$ All sample interviews were originally in the Seto language. The texts were transcribed from video and sound recordings. The recordings made by Igor Tõnurist and the material collected and recorded by us in 2007, 2008 and 2012 are kept in the Estonian Folklore Archives. Henceforth in this article references to the recorded material include the name of the village and date of recording.

${ }^{19}$ During our fieldwork we experienced on a number of occasions the older singers' willingness to improvise songs in any situation, and indeed, they could break into singing in the most unexpected places. For instance, Olga M. performed an improvised farewell song in a dark car full of people when driving home after a party at the community house. Lidia K., who was also in the car, asked the driver to first take Olga M. home, so that she would not miss the song. Another time, when we had packed our recording equipment after an interview and recording of songs that had taken a couple of hours, our hostess and her guest started singing an improvised dedication and farewell song.

${ }^{20}$ Representatives of the older generation of singers in this article are Maria V. (b. 1927) and Olga M. (b. 1932). The latter, while being close in age to the women singing in the choir, represented the older generation in terms of lifestyle, poorer command of Russian and singing style.

${ }^{21}$ According to an old tradition, which dates back to the time before the Setos were given family names, it is still customary in Seto villages in Siberia to call people by the name of their father, grandfather, mother, brother or village. Semmeni Olli means Semyon's Olga, in this case, Olga, Semyon's daughter.

${ }^{22}$ According to the Setos in Siberia, the first exile generation married only inside the ethnic group. The next generation showed some marriages with Lutheran Estonians, and by the present day the nationality or language is no longer relevant when choosing a partner in life. This may also explain the preferences of Estonian- or Russianlanguage songs in certain periods of time.

${ }^{23}$ The sound tapes with material recorded in 1987 and 1988 by ethnologist Igor Tõnurist are the only known song recordings from these villages until our fieldwork in the late 2000 s. There is also a small amount of material, including singing, recorded on VHS tapes by the local villagers at the end of the 1990 s.

${ }^{24}$ On the historical principles of selection of recording songs, see, e.g., Kalkun 2011; Oras 2008; 2009; also Kallio 2013: 332; Timonen 2004: 13ff. 
${ }^{25}$ In popular Seto terminology, a 'word' may stand either for a single word or a smaller unit within the song (verse-internal formula, verse, parallel word pair or a broader unit, such as a 'motif' or 'type', commonly used among folklorists). See also Virtanen $1981 ; 1987 ; 1994$.

${ }^{26}$ However, it is typical of the older songs sung most often by the community house choir that the lead singer does not sing along for long and the choir joins in as soon as they recognise the verse.

${ }^{27}$ See Kalkun \& Ojamaa 2009.

${ }^{28}$ During our first fieldwork trip in 2007, Maria O.'s mother was still alive, but we had no chance to meet her. Unfortunately, by our 2008 fieldwork, she had already passed away.

${ }^{29}$ In Estonian folk music, the transitional form is characterised by the combining of elements of earlier regilaul songs and the poetry of newer end-rhymed songs (see Rüütel 2012).

${ }^{30}$ Khaidak village, August 2008.

${ }^{31}$ Khaidak village, August 2008.

${ }^{32}$ In Russian 'sochinit' means to 'create', 'write', 'compose', 'put together', 'invent'.

${ }^{33}$ Even the earliest, 19th-century records describing the Seto singing style were highly critical of the melodies, regarding their musical motivation as inadequately short and the performers' singing voices vulgar (see Schlegel 1831; also Kalkun 2011). Also, in the early 20th century, Karelians spoke of their earlier singing style in disparaging terms and considered singing these songs sinful (Huttu-Hiltunen 2009: 53ff.).

${ }^{34}$ Khaidak village, August 2008.

${ }^{35}$ Khaidak village, August 2008.

${ }^{36}$ Khaidak village choir; audio tape recorded by Igor Tõnurist, September 20, 1988.

${ }^{37}$ On the concept and meaning of the term 'cultural tradition' see, e.g., KirshenblattGimblett 1995; Kuutma 2009a.

${ }^{38}$ Assigning folk songs to types was adopted in the research methodology of the historicalgeographic school as a necessary step in identifying the age and origin of the songs, one that would facilitate comparison (see Bennett 2005 [1994]; Hafstein 2005; also Kalkun 2011: 91ff.).

${ }^{39}$ In their respective PhD theses, Liina Saarlo (2005: 31ff.) and Mari Sarv (2008: 121ff.) have studied the relationship of improvisation and tradition in the earlier Estonian folk song. Venla Sykäri (2011: 69ff.) has recently analysed the performance and poetics of Cretan improvisational songs; see also Jane C. Sugarman's (1997: 117ff.) work on Prespa Albanians' wedding songs. Even more recently, Žanna Pärtlas (2013) has investigated the different types of musical improvisation in Seto text-oriented singing culture. 
${ }^{40}$ See also the works of Finnish folklorist Leea Virtanen $(1981 ; 1987 ; 1994)$ who has, among other things, analysed the Setos' attitudes towards their songs.

${ }^{41}$ One of the most important Seto festivities in modern days. The festivity, which was initiated by Seto-born folklorist Paul Hagu in 1994, has become an annual celebration of increasing popularity. It entails elements of the traditional Seto kirmask (spontaneous singing, dancing, eating and drinking), but also various competitions, including one to find the best singer of the improvisational song - sõnoline.

${ }^{42} \mathrm{~A}$ persistent issue in Seto folklore is that of its belonging. The problem became particularly acute in 1930, when the collection and storing of Seto folklore in Estonian and Finnish archives was started (see Kalkun 2011; Kuutma 2009b).

${ }^{43}$ Krasnoyarsk Krai has a multiethnic population of indigenous groups, emigrants and deportees of various ethnicities. In 2006, a lavishly illustrated guide to ethnicities living in the Krasnoyarsk Krai was published, introducing 137 different ethnic groups, including Estonians and Setos (Rafikov 2006).

44 The use of specific Seto modes of melody has become rarer also among the Setos in Estonia. In the 1990s, only choirs of women of mostly advanced age sang songs in these modes (Pärtlas \& Oras 2012).

\section{REFERENCES}

Ambrazevičius, Rytis \& Pärtlas, Žanna 2011. Searching for the "Natural" Origins of the Symmetrical Scales: Traditional Multipart Setu Songs. Journal of Interdisciplinary Music Studies, Vol. 5, No. 1, pp. 1-17. Available at http://www.musicstudies.org/ jims201151/Ambrazevicius_JIMS_11050101.pdf, last accessed on May 23, 2014. Anderson, Benedict 1994 [1983]. Imagined Communities: Reflections on the Origin and Spread of Nationalism. London \& New York: Verso.

Bauman, Richard 1988 [1986]. Story, Performance, and Event: Contextual Studies of Oral Narrative. Cambridge: Cambridge University Press.

Bennett, Gillian 2005 [1994; doi:10.1080/0015587X.1994.9715871]. Geologists and Folklorists: Cultural Evolution and "The Science of Folklore". Folklore: Critical Concepts in Literary and Cultural Studies. Edited by Alan Dundes. Volume IV. Folkloristics: Theories and Methods. London \& New York: Routledge, pp. 370-393. Briggs, Charles L. 1988. Competence in Performance: The Creativity of Tradition in Mexicano Verbal Art. Philadelphia: University of Pennsylvania Press.

Buck, Willem 1909. Petseri eestlased. [Estonians in Pechory.] Tartu: Postimehe Kirjastus. Korb, Anu \& Peebo, Kadri (comps.) 1995. Siin Siberi maa peal kasvanud: Ülem-Suetuki ja Viru-Pulani lood ning laulud. Eesti asundused I. [Grown Up in Siberia: Stories and Songs from Verkhnii Suetuk and Verkhnaia Bulanka. Estonian Settlements, Vol. 1.] Tartu: Eesti Kirjandusmuuseum.

Hafstein, Valdimar Tr. 2005. Biological Metaphors in Folklore Theory: An Essay in the History of Ideas. Folklore: Critical Concepts in Literary and Cultural Studies. 
Edited by Alan Dundes. Volume IV. Folkloristics: Theories and Methods. London \& New York: Routledge, pp. 407-435.

Honko, Lauri \& Honko, Anneli \& Hagu, Paul 2003. The Maiden's Death Song \& The Great Wedding: Anne Vabarna's Oral Twin Epic written down by A. O. Väisänen. FF Communications, No. 281. Helsinki: Academia Scientiarum Fennica.

Hurt, Jakob 1904a. Über die pleskauer esten oder die sogenannten setukesen. Anzeiger der Finnisch-Ugrischen Forschungen. Band III, Heft 3. Helsingfors: Druckerei der Finnischen Literatur-Gesellschaft, pp. 185-205.

Hurt, Jakob 1989 [1904]. Kiri auustatud ajaloo-uurijale V. Reiman'ile. [A Letter to an Honoured Historian V. Reiman.] In: Ülo Tedre (comp.) Mida rahvamälestustest pidada. Artiklite kogumik. [What to Make of Folk Memory: A Collection of Articles.] Tallinn: Eesti Raamat, pp. 145-149.

Huttu-Hiltunen, Pekka 2009. Länsivienalainen runolaulu 1900-luvulla. Kuuden runolaulajan laulutyylin kulttuurisensitiivinen musiikkianalyysi. [Runosong in Western Vienna in the 20th Century.] Helsinki: Sibelius-Akatemia \& Kuhmo: Juminkeko.

Jääts, Indrek 1998. Setude etniline identiteet. [The Ethnic Identity of the Setos.] Studia Ethnologica Tartuensia 1. Tartu: Tartu Ülikooli etnoloogia õppetool.

Juhkason, Grethe \& Kalkun, Andreas \& Lindström, Liina \& Plado, Helen 2012. Petserimaa setodest ja nende keelest 2010.-2011. a. välitööde põhjal. [Setos of the Pechorsky District: On Their Current Situation and Their Language, Based on Fieldwork in 2010-2011.] Õdagumeresoomõ piiriq. Läänemeresoome piirid. Finnic borders. Võro Instituudi Toimõndusõq. Publications of Võro Institute 26. Võru: Võro Instituut, pp. 11-29.

Kalkun, Andreas 2004. Leiko: 40 aastat Värska leelokoori. [Leiko: 40th Anniversary of the Värska Choir.] Tallinn: Setumaa Kultuuriprogramm.

Kalkun, Andreas 2008. A Woman's Voice in an Epic: Tracing Gendered Motifs in Anne Vabarna's Peko. Journal of Ethnology and Folkloristics, Vol. 2, No. 2, pp. 25-45. Available at http://www.jef.ee/index.php/journal/article/view/28/pdf_27, last accessed on May 26, 2014.

Kalkun, Andreas 2011. Seto laul eesti folkloristika ajaloos. Lisandusi representatsiooniloole. [Seto Singing Culture in Studies of Estonian Folklore: A Supplement to the History of Representation.] Tartu: Tartu Ülikooli Kirjastus. Available at http://dspace. utlib.ee/dspace/bitstream/handle/10062/18222/kalkun_andreas.pdf?sequence=1, last accessed on May 26, 2014.

Kalkun, Andreas \& Korb, Anu (comps.) 2012. Siberi setode laulud. Songs of Siberian Seto. Pesni sibirskikh seto. Tartu: Eesti Kirjandusmuuseumi Teaduskirjastus.

Kalkun, Andreas \& Ojamaa, Triinu 2009. Orthodox Chanting and Traditional Singing: Conflicts and Compromises. In: Piotr Dahlig (ed.) Traditional Musical Cultures in Central-Eastern Europe: Ecclesiastical and Folk Transmission. Warsaw: University of Warsaw \& Polish Academy of Sciences, pp. 157-175. Available at http://laul.setomaa.ee/pdf/poola_artikkel.pdf, last accessed on May 26, 2014.

Kallio, Kati 2013. Laulamisen tapoja: Esitysareena, rekisteri ja paikallinen laji länsiinkeriläisessä kalevalamittaisessa runossa. [Ways of Singing: Performance Arena, 
Register and Local Genre in West-Ingrian Oral Poetry.] Helsinki: University of Helsinki. Available at https://helda.helsinki.fi/bitstream/handle/10138/42072/ vaitoskirja_Kallio_2013.pdf?sequence=1, last accessed on May 26, 2014.

Keem, Hella 1997. Võru keel. [Võro Language.] Tallinn: Eesti Teaduste Akadeemia Emakeele Selts.

Keem, Hella \& Käsi, Inge 2002. Võru murde tekstid: Eesti murded VI. [Texts in Võro Dialect: Estonian Dialects VI.] Tallinn: Eesti Keele Instituut.

Kirshenblatt-Gimblett, Barbara 1995. Theorizing Heritage. Ethnomusicology, Vol. 39, No. 3, pp. 367-380. http://dx.doi.org/10.2307/924627.

Korb, Anu 2005. Venemaal rahvuskaaslasi küsitlemas: folkloristliku välitöö metoodilisi aspekte. [Interviewing Estonians in Russia: Methodical Aspects of Folkloristic Fieldwork.] Studia Ethnologica et Folkloristica Tartuensia 9. Tartu: Tartu Ülikooli Kirjastus.

Kreutzwald, Friedrich Reinhold 1848. Mittheilung über Volkslieder bei den im Pleskauschen Gouvernement angesiedelten Esten, nebst einer Beilage mit Liederproben. In: Verhandlungen der gelehrten Estnischen Gesellschaft zu Dorpat. Zweiter band. Zweites Heft. Doprat: H. Laakmann, pp. 43-62.

Kuutma, Kristin 2005. Pärimuskultuurist kultuurisümboliks. Saami etnograafia ja seto eepose saamislugu. [From Traditional Culture to the Symbol of Culture: The Creation of Sami Ethnography and a Seto Epic.] EKLA töid kirjandusest ja kultuuriloost 3. Tartu: Eesti Kirjandusmuuseum.

Kuutma, Kristin 2006. Collaborative Representations: Interpreting the Creation of a Sámi Ethnography and a Seto Epic. FF Communications No. 289. Helsinki: Suomalainen tiedeakatemia.

Kuutma, Kristin 2009a. Cultural Heritage: An Introduction to Entanglements of Knowledge, Politics and Property. Journal of Ethnology and Folkloristics, Vol. 3, No. 2, pp. 5-12. Available at http://www.jef.ee/index.php/journal/article/view/9/ pdf_8, last accessed on May 26, 2014.

Kuutma, Kristin 2009b. Who Owns Our Songs? Authority of Heritage and Resources for Restitution. Ethnologia Europaea, Vol. 39, No. 2, pp. 26-40.

Laanemets, Liisi 2012. Seto identiteedi loomisest ja hoidmisest väljaspool Setomaad tegutseva leelokoori näitel. [Creating and Retaining Seto Identity: Case Study of a Seto Choir Existing Outside Setomaa.] Res musica 4. Eesti Muusikateaduse Seltsi ja Eesti Muusika-ja Teatriakadeemia muusikateaduse osakonna aastaraamat. [Yearbook of Estonian Musicological Society and Musicological Department of the Estonian Academy of Music and Theatre.] Tallinn: EMTS \& EMTA, pp. 75-96.

Lõuna, Kalle 2003. Petserimaa. Petserimaa integreerimine Eesti Vabariiki 1920-1940. [The Pechory Region and Its Integration into the Republic of Estonia 1920-1940.] Tallinn: Eesti Entsüklopeediakirjastus.

Muszkalska, Božena \& Polak, Tomasz 2009. Syncretism in the Musical Culture of the Polish Hollanders in Siberia. In: Piotr Dahlig (ed.) Traditional Musical Cultures in Central-Eastern Europe: Ecclesiastical and Folk Transmission. Warsaw: University of Warsaw \& Polish Academy of Sciences, pp. 213-226. 
Nigol, August 1918. Eesti asundused ja asupaigad Wenemaal. [Estonian Settlements and Places of Residence in Russia.] Tartu: Postimees. Available at http://ida.aule. ee/raamatud/nigol1918_orig.pdf, last accessed on May 27, 2014.

Olson, Laura J. \& Adonyeva, Svetlana 2012. The Worlds of Russian Village Women: Tradition, Transgression, Compromise. Madison: The University of Wisconsin Press.

Oras, Janika 2008. Viie 20. sajandi naise regilaulumaailm. Arhiivitekstid, kogemused ja mälestused. [The Regilaul World of Five 20th Century Women: Archival Texts, Experiences and Memories.] Eesti Rahvaluule Arhiivi Toimetused 27. Ed. by Mall Hiiemäe. Tartu: Eesti Kirjandusmuuseumi Teaduskirjastus.

Oras, Janika 2009. Lõik eesti folkloorikogumise loost: Nõukogude aja helisalvestused. [A Fragment from the History of Estonian Folklore Collection: Sound Recordings from the Soviet Period.] Akadeemia, No. 4, pp. 703-723.

Oras, Janika 2012. Recordings of Songs by Estonian Prisoners of War: Repertoire and Its Representations. In: Jaan Ross (ed.) Encapsulated Voices: Estonian Sound Recordings from the German Prisoner-of-War Camps in 1916-1918. Köln \& Weimar \& Wien: Böhlau Verlag, pp. 147-177.

Paas, Fr. E. 1928. Sega-abielud ja nende mõju rahvusesse piiriäärsetes maakondades Eestis. [Mixed Marriages and Their Effect on the Nation in Peripheral Counties in Estonia.] Eesti Kirjandus, No. 6, pp. 294-306. Available at http://www.digar. ee/arhiiv/nlib-digar:53307, last accessed on May 27, 2014.

Pajusalu, Karl 2000. Lõunaeesti murdeliigendusest. [About the Articulation of SouthEstonian Dialects.] In: K. Pajusalu \& S. Iva (eds.) Õdagumeresoome piirisü̈̈meq. Keskused läänemeresoome piiridel. [Centres at the Baltic-Finnic Borders.] Võro Instituudi toimõndusõq 10. Võro: Võro Instituut, pp. 76-86.

Pajusalu, Karl \& Hennoste, Tiit \& Päll, Peeter \& Niit, Ellen \& Viikberg, Jüri (comps.) 2009. Eesti murded ja kohanimed. [Estonian Dialects and Place Names.] Tallinn: Eesti Keele Sihtasutus.

Pärtlas, Žanna 1995. Mitmehäälsuse rollist erinevate rahvuslike folklooritraditsioonide vastastikusel mõjutamisel. [On the Role of Polyphony in the Reciprocal Influence of Various Folklore Traditions.] Eksitaja: Pro Folkloristica 3. Tartu: Eesti Kirjandusmuuseum, pp. 56-58. Available at http://www.folklore.ee/era/nt/PF3/, last accessed on May 27, 2014.

Pärtlas, Žanna 1997. Tähelepanekuid setu laulu laadiehitusest ja mitmehäälsusest. [Observations of Style and Polyphony of Seto Songs.] Teater. Muusika. Kino, No. 1, pp. 23-28. Available at http://www.digar.ee/arhiiv/et/perioodika/104168, last accessed on May 27, 2014.

Pärtlas, Žanna 2010. Setu Multipart Singing: Comparison of Written Sources and Sound Recordings. In: Susanne Ziegler \& Urban Bareis (eds.) Historical Sources and Source Criticism. Stockholm: Svenskt Visarkiv, pp. 227-237.

Pärtlas, Žanna 2013. On Musical Creativity in "Text-Oriented" Song Traditions: The Processes of Melodic Variation in Seto Multipart Songs. In: Ardian Ahmedaja (ed.) Local and Global Understandings of Creativities: Multipart Music Making and the Construction of Ideas, Contexts and Contents. Cambridge: Cambridge Scholars Publishing, pp. 60-76. 
Pärtlas, Žanna \& Oras Janika 2012. Seto traditsioonilise laulumaneeri jäljendamise eksperimendist. [Results from an Experiment in Emulating the Traditional Seto Singing Style.] Res musica 4. Eesti Muusikateaduse Seltsi ja Eesti Muusika- ja Teatriakadeemia muusikateaduse osakonna aastaraamat. [Yearbook of Estonian Musicological Society and Musicological Department of the Estonian Academy of Music and Theatre.]. Tallinn: EMTS \& EMTA, pp. 22-43.

Piho, Mare 1994. Setukaiskylät Siperiassa. [Seto Villages in Siberia.] Helsinki: Tuglasseura.

Rafikov, R. (ed.) 2006. Etnoatlas Krasnoiarskogo kraia. [Ethnographic Atlas of Krasnoyarsk Krai.] Krasnoiarsk: Platina.

Raun, Toivo U. 1991. The Petseri Region of the Republic of Estonia. Jahrbücher für Geschichte Osteuropas, Vol. 39, pp. 514-532. Available at http://daten.digitalesammlungen.de/ db/bsb00003839/images/index.html?fip=193.174.98.30\&seite= 538\&pdfseitex=, last accessed on May 27, 2014.

Raun, Toivo U. 2007. The All-Estonian Congress in Tartu, November 1905: A Reassessment. Journal of Baltic Studies, Vol. 38, No. 4, pp. 383-400. http:// dx.doi.org/10.1080/01629770701682624.

Rüütel, Ingrid 1983. Eesti uuemad laulumängud 2. [Newer Estonian Singing Games II.] Tallinn: Eesti Raamat.

Rüütel, Ingrid 1998. Estonian Folk Music Layers in the Context of Ethnic Relations. Folklore: Electronic Journal of Folklore, Vol. 6, pp. 32-69. doi:10.7592/FEJF1998.06. ruutel.

Rüütel, Ingrid 2012. Eesti uuema rahvalaulu kujunemine. [The Formation of the Newer Estonian Folk Song.] Tartu: Eesti Kirjandusmuuseumi Teaduskirjastus.

Saarlo, Liina 2005. Eesti regilaulude stereotüüpiast. Teooria, meetod ja tähendus. [The Stereotypy of Estonian Runo Songs: Theory, Method and Meaning.] Dissertationes Folkloristicae Universitatis Tartuensis 5. Tartu: Tartu Ülikooli Kirjastus.

Särg, Taive 2012. Paralleelsed või lõikuvad sirged? Torrõ ja killõ helikõrgustest kahes seto laulus akustiliste mõõtmiste põhjal. [Changes in Melody Scale in the Course of Gradual Rise of Pitch in Seto Folk Song: The Results of Acoustic Measurements of Upper Voice killõ and Lower Voice torrõ.] Res Musica 4, pp. 44-62.

Sarv, Mari 2008. Loomiseks loodud: regivärsimõõt traditsiooniprotsessis. [Made for Making: Runo-Song Metre in the Process of Tradition.] Eesti Rahvaluule Arhiivi Toimetused 26. Tartu: Eesti Kirjandusmuuseumi Teaduskirjastus.

Sarv, Vaike 1997. Setu improvisatsioonid esimesel Kuninga kuulutamisel. [Seto Improvisations at the Announcing of the First King.] Lee 4. Ümin. Tartu: Eesti Rahva Muuseumi Sõprade Selts, pp. 79-95.

Sarv, Vaike 2000. Setu itkukultuur. [Seto Lamenting Culture.] Ars Musicae Popularis, Vol. 14. Tartu: Eesti Kirjandusmuuseum, etnomusikoloogia osakond \& Tampere: Tampereen yliopiston kansanperinteen laitos. 
Schlegel, Christian Hieronymus Justus 1831. Reisen in mehrere russische Gouvernements in den Jahren 1801, 1807, 1815, 1830. Sechstes Bändchen. Reise von St. Petersburg nach dem Pleskowschen Gouvernement im Monat Julius 1815. Meiningen: Friedemann Keyßner. Available at http://dspace.utlib.ee/dspace/ handle/10062/36306, last accessed on May 27, 2014.

Seto leelo 2009 = Seto Leelo, Seto polyphonic singing tradition. The Representative List of the Intangible Cultural Heritage of Humanity. Available at http://www.unesco. org/culture/ich/index.php?RL=00173, last accessed on May 27, 2014.

Shchurov 2007 = Shchurov, Viacheslav Mikhailovich. Zhanry russkogo muzykal'nogo fol'klora I. Istoriia, bytovanie, muzykal'no-poeticheskie osobennosti. [Genres of Russian Musical Folklore I.] Moskva: Muzyka.

Sugarman, Jane C. 1997. Engendering Song: Singing and Subjectivity at Prespa Albanian Weddings. Chicago Studies in Ethnomusicology. Chicago and London: University of Chicago Press.

Sykäri, Venla 2011. Words as Events: Cretan Mantinádes in Performance and Composition. Helsinki: Finnish Literature Society.

Tarkka, Lotte 2005. Rajarahvaan laulu. Tutkimus Vuokkiniemen kalevalamittaisesta runokulttuurista 1821-1921. [Songs of the Border People: Kalevala-Metre Poetry in Vuokkiniemi Parish 1821-1921.] Helsinki: Suomalaisen Kirjallisuuden Seura.

Timonen, Senni 2004. Minä, tila, tunne. Näkökulmia kalevalamittaiseen kansanlyriikkaan. [Self, Space, Emotion: Aspects of Kalevala-Metre Folk Lyric.] Suomalaisen Kirjallisuuden Seuran Toimituksia 963. Helsinki: Suomalaisen Kirjallisuuden Seura.

Ustav, Karl 1908. Pihkwa eestlased. [Estonians of Pskov.] Kirjutanud K. Usstaw. Tartu: Postimehe Kirjastus.

Virtanen, Leea 1981. Setukaisnaisten lauluperinne. [The Song Tradition of Seto Women.] Suomen Antropologi, No. 1, pp. 29-40.

Virtanen, Leea 1987. Setukaiset kertovat lauluistaan. [The Setos Speak of Their Songs.] In: Leea Virtanen (ed.) Viron veräjät: Näkökulmia folkloreen. Tietolipas 105. [Estonian Gates: Views on Folklore.] Helsinki: Suomalaisen Kirjallisuuden Seura, pp. 161-194.

Virtanen, Leea 1994. Singers on their Songs: The Act of Singing as Perceived by Singers in the Setu Region of Estonia Today. In: Michael Branch \& Celia Hawkesworth (eds.) The Uses of Tradition: A Comparative Enquiry into the Nature, Uses and Functions of Oral Poetry in the Balkans, the Baltic, and Africa. London: School of Slavonic and East European Studies, University of London, pp. 231-249. 


\section{ONLINE SOURCES}

a-pesni $=$ Dvorovye $i$ blatnye. [Songs from Street and Prison.] http://a-pesni.org/dvor/ Dvor.php, last accessed on May 28, 2014.

Antologiia $=$ Antologiia odnoi pesni . [Anthology of One Song.] Ia vstretil rozu ... [I Met a Rose...] http://shanson-e.tk/forum/archive/index.php/t-68321.html, last accessed on May 28, 2014.

Dvorovye romansy $=$ Dvorovye romansy nachala 70- $k$ h. [Street Romances from the Beginning of the 1970s.] http://music.lib.ru/b/boris_d/alb1.shtml, last accessed on May 28, 2014. 


\title{
ON ESTONIAN FOLK CULTURE: PRO ET CONTRA
}

\author{
Piret Õunapuu
}

\begin{abstract}
The year 2013 was designated the year of heritage in Estonia, with any kind of intangible and tangible heritage enjoying pride of place. Heritage was written and spoken about and revived in all kinds of ways and manners. The motto of the year was: There is no heritage without heir.

Cultural heritage is a comprehensive concept. This article focuses, above all, on indigenous cultural heritage and, more precisely, its tangible (so-called object) part. Was the Estonian peasant, 120 years back, with his gradually increasing self-confidence, proud or ashamed of his archaic household items? Rustic folk culture was highly viable at that time. In many places people still wore folk costumes - if not daily, then at least the older generation used to wear them to church. A great part of Estonians still lived as if in a museum. Actually, this reminded of the old times that people tried to put behind them, and sons were sent to school in town for a better and more civilised future.

In the context of this article, the most important agency is peasants' attitude towards tangible heritage - folk culture in the widest sense of the word. The appendix, Pro et contra, at the end of the article exemplifies this on the basis of different sources.
\end{abstract}

Keywords: creation of national identity, cultural heritage, Estonian National Museum, Estonian Students' Society, folk costumes, folk culture, Learned Estonian Society, material heritage, modernisation, nationalism, social changes

\section{HISTORICAL BACKGROUND}

By the end of the 19th century, the Russification period, several cultural spaces had evolved in the Baltic countries: indigenous, German and Russian. At the turn of the century, a social structure characteristic of modern society started to emerge in Estonia. Along with the rising entrepreneurship and purchasing farms for freeholds, western values became fixed in Estonian society. Estonians no longer wished to be raw material for modernisation, but demanded more power in making decisions about their own destiny. Western Europe regarded the Baltic States as part of Russia, which considerably differed from inner Russia and followed German cultural traditions. Nearly nothing was known about these indigenous peoples and they were regarded as uncivilised peasantry. 
The beginning of Estonian national movement had been inseparably connected with the evolution of civil publicity. The tradition of society movement dated back to as far as the 19th century. The turn of the century constituted an important turning point in history. The conflict escalated, as side by side with the rising new aspects, the old traditional ones existed, both in the way of living and thinking. One of the objectives of the then modernisation was to change people's everyday environment, and this inevitably brought along the re-estimation of the former. The traditional peasant way of life was gradually losing its rustic content; yet, the number of intellectuals who were able to value its essence grew considerably. In cultural life, significant events occurred both in the sphere of art and literature.

Yet, the educated Estonian of the period shaped a new ideology on the basis of the idealised folk culture, by means of which they could find in their past something to be proud of, and to prove to the whole world that Estonians were also a civilised people. In this spirit, the Estonian National Museum was founded in 1909.

\section{ESTONIAN NATIONAL MUSEUM}

The foundation for the museum collections was laid right after the establishment of the museum, and during the first decade nearly 20,000 artefacts were collected, about two-thirds of them in the years 1911-1913. The fact that a museum in which people mainly worked for free, for the good of their homeland, aimed at collecting material heritage by parishes from all over Estonia, and was able to involve tens and tens of people in this work, is unique in the history of the whole world. This action resulted in not only voluminous but also valuable collections of artefacts, which made their way to the museum before the devastating First World War broke out. Prior to the establishment of the Republic of Estonia (1918), the heritage collectors of the Estonian National Museum visited all the parishes in Estonia, except for those with Swedish population. The time was favourable. Plenty of old things were still available, although most of the collectors complained in their diaries that there was nothing to be found any more. The reports and diaries submitted after the collection expedition constitute a valuable source for research. In addition to general descriptions, they include stories about people's attitudes towards the collectors and thereby also estimates of their activity. 


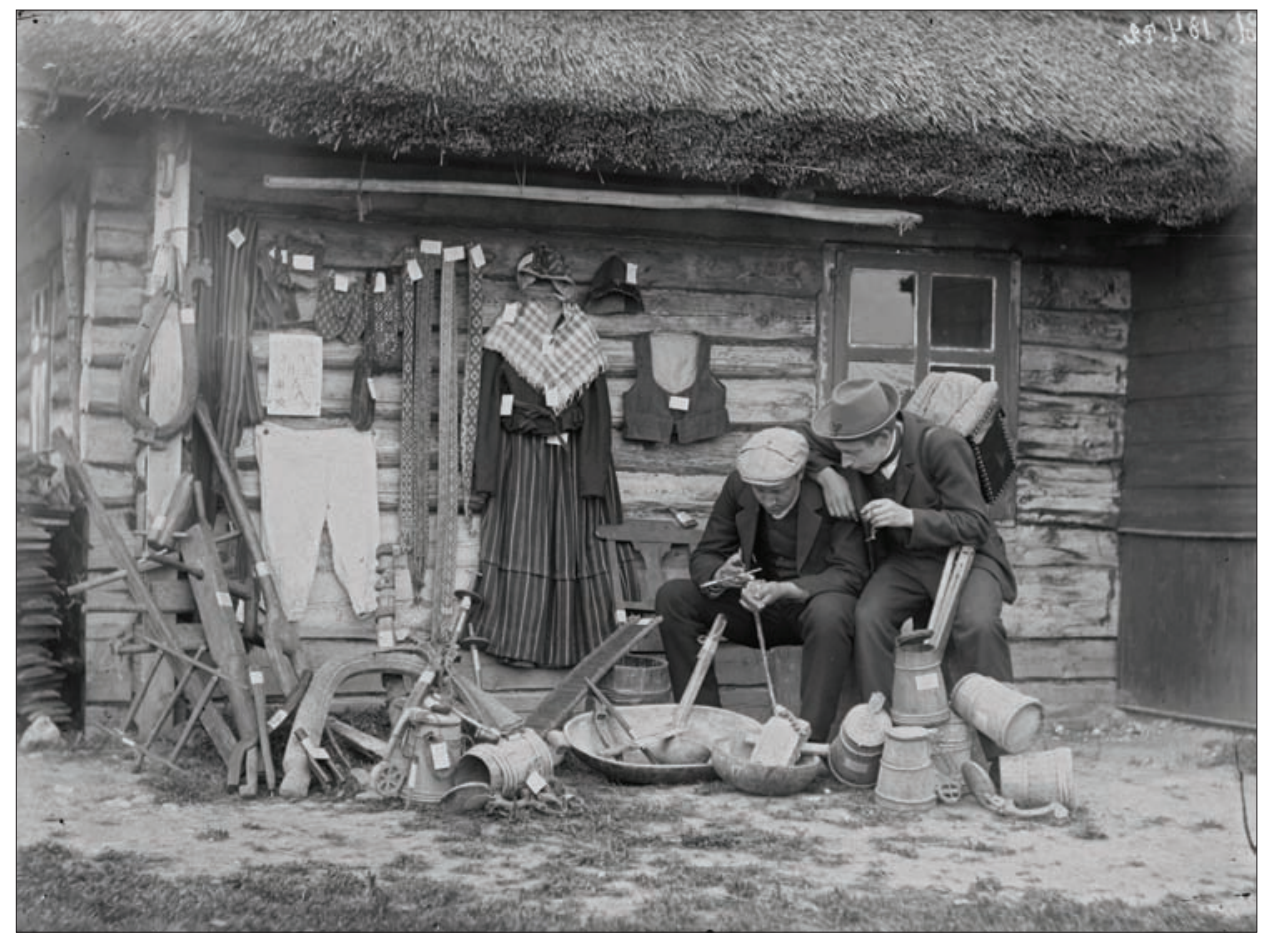

Figure 1. Heritage collectors in Karuse parish in 1912. ERM Fk 184:72.

Several cultural historians and ethnologists have made attempts to analyse Estonians' attitude towards their national heritage. Ea Jansen has dwelt upon this topic in two books $(2004,2007)$ and in an overview in the fifth volume of Estonian history (2010: 382-395). The same topic has also been analysed by Toomas Karjahärm and Väino Sirk (1997). Versatile treatments of the indigenous cultural heritage and changes in attitudes towards it have been given by ethnologists Ants Viires (2001) and Elle Vunder (2003: 47-70; 2008: 65-71); from the younger generation of ethnologists also by Anu Kannike (1994: 7-29).

In this article, I have mainly used materials from the archives of the Estonian National Museum, such as, for example, the diaries and reports of collection expeditions, as well as materials from the press of that period. 


\section{THE FIRST WAVE IN FOLK CULTURE EVALUATION IN THE LAST QUARTER OF THE 19TH CENTURY}

It was a long and hard way to the point of admitting that Estonian culture, the creation of our own people, the oral and material heritage, could be something as valuable as to be worth preserving for the future generations. For each nation, becoming aware of themselves - the birth of the nation - is one of the most significant moments in its history (Laar 2010a: 219). The activity of pastors-estophiles ${ }^{1}$ had greatly contributed to the survival and valuation of national memory. The expanding worldview in the middle of the century gave a considerable impetus to the rise of national self-awareness. The earlier social evolution had been slow, featuring only few fluctuations, yet by the third quarter of the 19th century abrupt and fast changes had occurred in Estonia. Everything important that happened in Europe reached, one way or the other, also the Baltic provinces of the Russian Empire. The spread of nationalism was especially remarkably influenced by the examples of Germany and Finland (Laar 2010b: 234).

Jakob Hurt ${ }^{2}$ had managed to make hundreds of people collect folklore; the importance of our oral folklore was well realised and the collection of folklore, thanks to Hurt's untiring work, was unprecedented. The publication of the Estonian national epic Kalevipoeg (Kalev's Son) in 1857-1861 had contributed much to the understanding of folklore as well as given an impetus to the collection work. The heyday of tangible heritage came later on. This process was typical of not only Estonia; this had also happened in other European countries earlier on.

How did the first Estonian-origin intellectuals, who came from peasant families, relate themselves to heritage? Most probably, the Estonians were enthused by the Finns, who differed by their political status, yet were similar in their folk culture.

The valuation of material culture was directly related to the idea of a museum. Several attempts were made to establish an Estonian museum; yet, the only more or less successful outcomes were the collections of the Learned Estonian Society (LES) ${ }^{3}$ and the Estonian Students' Society (ESS) ${ }^{4}$. The former, however, considered the collection of Estonian material heritage largely from the point of view of scientific interest, focusing, rather, on the preservation of the existing exotica. The few Estonian-minded voices in society were overpowered by the ruling German mentality. The reasons for kindling interest in the collection of items of Estonian folk culture came from outside the Learned Estonian Society. The 10th All-Russian Archaeology Congress was planned to be held in Riga in 1896, with accompanying ethnography exhibitions from Estonia and Latvia. As 
the LES had already participated in the former archaeology congresses, it was one of the chief organisers of the Riga congress. Preparations for the congress started already a few years earlier. In 1893, an announcement was published in the newspaper Olevik (The Present), which notified the readers about the idea of establishing a museum of old folk items, for which old artefacts were planned to be collected from people, so people were admonished to keep the objects worth preservation (Uuemad sõnumed 1893: 960). On June 19-20, 1894, the 5th Estonian Song Festival took place in Tartu. On this occasion, an exhibition was organised of all the artefacts collected until then, and it was put on display for everybody interested on two days of the Song Festival, June 19 and 20. On both days, the exhibition opened for free for a few hours. Explanations of the display were given by Oskar Kallas (Pino 1998: 40). During the two days, the exhibition drew an audience of 850 people (Kohalikud sõnumid 1894). Heritage items for the museum of the LES were collected by several members of the society. However, the LES exposition in Riga attracted no special attention in comparison to the Latvian ethnography exhibition, which had a spectacular open air section. This was the reason why heritage enthusiasm gradually faded away.

The Estonian Students' Society was rather slow to implement the idea; yet, along with the increase in nation-mindedness and following the example of Finnish students, the museum gradually started to gain ground.

The leading figure in this process was Oskar Kallas ${ }^{5}$, who collected both oral and material heritage for the LES, and also acted as a zealous agent in the establishment of the museum and the library of the Estonian Students' Society. Kallas considered it essential that artefacts were collected and preserved for the future generations; the organisation orchestrating the establishment of the museum and collecting heritage was not so important to him. His reminiscences about donating artefacts to the museum of the ESS provide the first example of pro et contra:

The primeval artefacts [of the museum of the ESS] originated from the secret treasury of my childhood, the attic of our house, which every now and then revealed some unexpected items. And my father, the sparklingeyed agent who implemented the ideas of the Society of Estonian Literati, abandoned everything without further explanations, when he heard about the scientific argumentation: Take what is worth taking! Mom had some doubts first, when I was trying to delve into the sanctuary of her clothes chest, if she was doing the right thing by unfolding her mother's keepsakes for everybody to laugh at; yet, my sister Minni, who frequently turned her warm enthusiasm in an enterprise into energetic work, ardently explained to our mother and also other sceptics that it was a great national venture and the future museum of the Estonian Students' Society, and it would 
be good to have a hand in it, enjoy pride of place in the beginning; as for later on, no one knows if there is room for anyone else. (Kallas 1923)

This is like a textbook example: the younger generation and the progressivelyminded father are able to see the value of Estonian folk culture and appreciate its significance; yet, the mother, the one to ensure continuity, cannot recognise it and is rather afraid of townspeople's disdainful attitude.

However, Kallas's society associates could not understand his admiration for material heritage. So they remarked ironically: You and your junk collection, it is as if we had won an elephant on an exhibition sale: we need to guard it, feed it, and also build a shed for it! (ibid.) As to the destiny of Estonian material heritage, the shed issue has been topical from the very beginning until today. Hopefully, this problem will eventually find a solution in the near future. ${ }^{6}$

\section{WAY TO EUROPE}

Timewise, the Estonian national movement coincided with the modernisation period. This in turn determined the necessity to define Estonians' position in the world and in the region, as well as explore and assess their relations with other peoples and cultures. With this in view, the issues of regional identity and external orientation became topical (Karjahärm 2010: 379). By the beginning of the following century, all the main trends and ideas of the western social thought had reached Estonia. The closest contacts were maintained with the northern neighbours - the Finns. Yet, we cannot underestimate the fact that already at the end of the 19th century many of our artists left for Europe via St. Petersburg, after they had studied either at St. Petersburg Academy of Arts or the so-called Stieglitz Art School' ${ }^{7}$. The most renowned figure among them was Kristjan Raud, who is also the most important one for the current topic.

The dialectics of transformation is expressed not only in the complex dialogue between the public and private social spheres, but also in the relationship between the new and the old, modernity and tradition (Vunder 2003: 47). As compared to the Awakening Period, attitude towards folk culture had changed by the first decade of the 20th century. Modernisation was targeted, above all, at changing the living environment, and this inevitably brought along the fading of traditions associated with the old way of life. Traditional peasant culture was gradually vanishing, and novel and modern phenomena were gaining ground in different spheres of life. People no more wore folk costumes or ate porridge from wooden bowls. 
As a result of the 1905 revolution, primary and secondary education became available in Estonian, and in 1906 the Emperor enforced a decree of the State Council, which stipulated that ethnic minorities were allowed to establish private schools with tuition in their mother tongue (ibid.: 383).

A number of significant events took place in cultural life: Ants Laikmaa Studio School was established in Tallinn and Kristjan Raud Studio in Tartu, the first Estonian art exhibition was organised, the Estonian Literary Society was founded in 1907, and so on. The number of periodicals increased quickly. By that time, a temporal distance had evolved, which helped to put a value on old things. The era shifted to the fore an inevitable necessity to get engaged in national culture. The most ardent advocates of national heritage were artists, with Kristjan Raud and Ants Laikmaa as the most influential among them. Raud, who had moved to Tartu in 1904, became a fervid participant in all the undertakings related to folk culture, and was specifically known as the author of articles that celebrated folk art and handicraft. At that time, the press served as a major influencing factor in shaping the public opinion. Yet, to a certain extent, Kristjan Raud's speeches and activity helped to overcome indifference.

Unlike artists, Estonian writers were not so unanimously enchanted by the folk art of the past. Despite Gustav Suits's ${ }^{8}$ famous appeal - "Let us be Estonians, but let us also become Europeans!" - the past for the members of Young Estonia, a neo-romantic literary group, was a harassing rather than encouraging factor. Yet, the older and more conservative part of writers were not following this ardency so wholeheartedly.

\section{KEEPING FOLK CULTURE ALIVE}

In the current context, research into the museum's collection work enables us to analyse, most directly and closely, people's attitude towards material folk heritage. The main initiator of the collection work was artist Kristjan Raud, who had already formerly gained experience in this sphere, as at the beginning of the century he had collected heritage items in the countryside for the museum of the LES. His attitude towards folk culture was national-romantically positive. Both Kristjan Raud's and Ants Laikmaa's texts were emotional appeals and helped to see what many contemporaries regarded as worthless junk and trash as something equal to professional art. Their writing helped to understand why creative people, who had studied abroad, turned so much attention to the old artefacts of Estonians who craved for innovations and better life (Summatavet 2007: 17). Raud repeatedly emphasised that the main aim in his life was to 
create an opportunity for painting a comprehensive picture of the life of our nation in the past (Matto).

In the early summer of 1909, the establishing year of the museum, the newspaper Postimees (The Courier) published a longer programmatic article by Kristjan Raud (1909) on the importance of collecting material heritage, in which he says:

The Estonian National Museum starts operating. The museum has in store extensive work of utmost significance, on which the future of Estonia depends in several ways. [---] This former authentic Estonian lifestyle, which was thriving in the old world, will give birth to a new life, igniting new fires, for the benefit and happiness of the future generations.

This comprehensive picture of the life of the nation in the past was very romantic. By his nature, Kristjan Raud was self-absorbed, serenely deliberate and often taciturn to the point of helplessness rather than talkative or outgoing (Kangro-Pool 1961: 69). He himself was inspired and spurred by the belief that the museum was worth establishing, and that a personal example was always the best booster in any undertaking.

This article is an attempt to provide an overview of how heritage collectors saw Estonia prior to the First World War. The efficiency of collection work and the ethnographic value of the collected artefacts, which until today have been in the focus of attention, have been left aside. By virtue of the fact that Oskar Kallas insisted on keeping a diary, we can guess what the Estonian village was like and what was Estonians' attitude towards material heritage and its collectors.

First, I would like to describe the people who followed the ENM's appeal to save what could still be saved. An average heritage collector was a young man, usually a university student, an intellectual or rather a person striving to become one. Many of the collectors were art students or artists. In 1912, the museum also decided to ask Estonian art students studying in Riga and St. Petersburg to participate in the collection work. Many of the collectors later on became renowned cultural figures - writers, artists, politicians, etc. The percentage of women among the collectors was relatively small, as at that time it was not considered acceptable for women to wander around in the countryside and ask for old artefacts on farmsteads.

In reality, heritage collection expeditions became novel and exciting ventures for many youngsters keen on arts and culture, at the same time serving as encounters with something old from somewhere in the past.

What was the vision that the heritage collectors developed about their beloved homeland during this complex work? The initial enthusiasm often crashed 


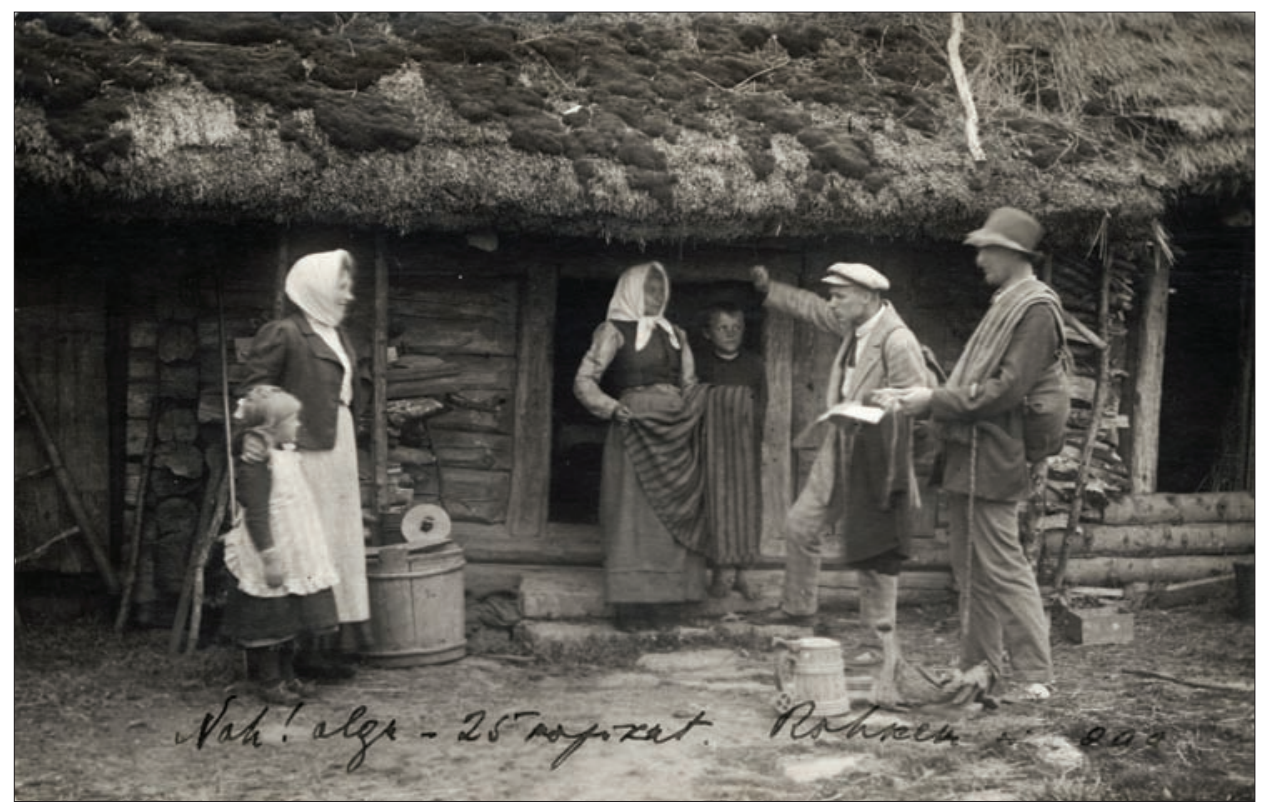

Figure 2. Heritage collectors Paul Ruus and Hans Karro in Saaremaa in 1913. ERM Fk 212:3.

against the wall of misunderstanding and the years spent at school had caused an inevitable breach. More often than not, young people analysed the things that they saw from a bystander's position. In reality the emotional slogan "I and my homeland and people are all one" did not apply any more. A certain impetus to this was also given by the museum, as they had recommended the collectors to describe both people, their appearances, characters and abodes. The expected ethnological description made the collectors assume the position of a distant viewer. For many heritage collectors, cleanliness and hygiene in farmhouses was one of the estranging factors. Although the youngsters predominantly came from the countryside, they had acquired a different kind of attitude along with education. Many diaries and reports mention these problems, if not disparagingly and directly, then at least fleetingly.

From the point of view of country people, heritage collection seemed to be an incomprehensible activity and the collectors themselves were regarded as suspicious. Local intellectuals - pastors, schoolteachers, etc. - often offered support to the heritage collectors. In case on Sunday morning the pastor had admonished people from his pulpit to welcome heritage collectors and find some old things for them, the result was always positive. 
Further on I present a few examples from heritage collectors' notes about what kind of attitude they encountered in the countryside, among the people who still mainly lived in the midst of this old folk culture, being so-called heirs of folk culture within this particular time period. I have omitted attitudes towards the museum as well as heritage collectors, and focused directly on only opinions about material heritage. The appendix presents different attitudes on the basis on diaries and reports preserved in museum archives. This can provisionally be called the lower stage of pro et contra: pro in case the attitude is rather respectful and contra in case it is disdainful.

\section{BECOMING A EUROPEAN}

Estonian culture turned from romanticism and realism to modernism in 1905, when a group of young men initiated the Young Estonia movement (19051915). Their first album of literary selections opened with the manifesto "The Strivings of Young People" by Gustav Suits, a poet and leader of the group, which proclaimed: Let us be Estonians, but also become Europeans! (Suits 1905: 3-19) This became the most influential slogan in the cultural reform for the whole century. Today, more than a hundred years later, Toomas Kiho expresses his concerns in an article under an ironic heading: Let us become Europeans, but not remain Estonians (Kiho 2013: 387-400). This indicates that more than a century we have tried to associate our culture and history with Europe.

In the second decade of the past century, European cultural life was really hectic, featuring enormous, fundamental upheavals. In Estonia, the end of the First World War and establishment of independent statehood opened the doors and also caused a certain wave of vertigo. It was a time for drinking in new ideas.

In addition to avant-gardism, Futurism, Expressionism, and Cubism were introduced from Europe but also Russia. It was highly essential to be, besides being educated, also special, modern, courageous, self-indulgent and arrogant; only then were you a truly cultured writer, poet, artist, etc. A novel behavioural type emerged - bohemianism.

A gap evolved between the more conservative, self-preservational national wing and the modern energetic younger intellectuals due to their different attitude towards national heritage. The latter maintained that for an independent country it was more important to partake in European culture than to collect innumerable tankards for the museum and advocate folk costumes.

So, for example, an interesting discussion was held in the media after the opening of the Estonian National Museum on Raadi Manor, between the Finnish-origin director of the museum, Ilmari Manninen, and Rasmus Kangro- 
$\mathrm{Pool}^{9}$, who resided in Hamburg. Despite the fact that Kangro-Pool himself had been collecting heritage items for the museum in Viru-Nigula parish ten years prior to that, he was most critical and ironic about the reviving of the old folk costume tradition. So he wrote:

The folk costume in Estonia and also in other places where it has survived is an indication of a darker, more remote corner, of how this, in its way of living, acts from force of habit of a small tribe. They have not reached the stage of evolution yet, in which the European culture and civilisation flourish that we are currently most eagerly striving for.

Estonians are not sages in sacred groves anymore; they do not singsong or participate in dances around a village swing. Only conservatism can suggest and is happy to see people in their old appearances. Because as it happens that the spirit of the time gives people their appearance (just like style to art), you could certainly also imagine a reverse process: the old appearance brings forward the way of thinking that once gave birth to this appearance. (Kangro-Pool 1923a; 1923b)

As the dream of independence had come true and the following one was to become a sterling European, this outfit was not suitable any more.

These accusations were refuted by Ilmari Manninen, director of the Estonian National Museum, in a long analysing article about the role of folk costumes, their importance and possibilities for wearing them, in which he said: It is not sensible to exchange Estonian idiosyncrasy for Europeanness (Manninen 1923). He also maintained that folk costumes could be delicately modernised, which has not always been approved by other folk costume researchers. Yet, Manninen also mentioned that not everyone was eligible to wear a folk costume:

Who are eligible to wear a folk costume? Only for the arguers' sake we have to say that Estonian folk costume is not suitable for men to wear. Men are not allowed to be as free in their clothing as women. This is one of the reasons why men often have to be ashamed of the folk costume. Besides, Estonian men's folk costumes lack any attraction. Nor do all women look good in folk costumes. Old women should beware of it. An old woman in a folk costume seems coquettish. But what about young women? Should I mention that not all of them are eligible to wear it either? Unfortunately, we can also encounter such young women who lack in-born judgemental taste and who present themselves in folk costumes for their own harm only. However, these women could also fail in choosing articles of European clothing. (ibid.) 
As we can assume from the above, Manninen limited the wear of folk costumes to only beautiful, young and refined women.

Today, however, folk dancers and singers, men and women, young and old all over Estonia wear folk costumes. No-one is worried whether the folk costume becomes them or not. The 20 th century has brought along many political upheavals and sufferings to Estonians. In hard times, people have relied on the intrinsic and homely, both on a personal and national scale. It is particularly in revolutionary times that people have turned to old traditional culture for support, overcrowding the Estonian National Museum to find examples in their ancestors' garments for making clothes for wedding, school graduation, and other ceremonies. The folk costume has become a modern Estonian's festive garment, which is good enough to go even to a presidential reception. We are not ashamed of our ancestors' sense of beauty but rather rejoice over it.

Never before in history have so many young Estonians left Estonia for Europe and even beyond. They go on both material and intellectual quests. They become Europeans and - I would really hope so - also remain Estonians.

\section{APPENDIX}

\section{Examples of pro et contra}

The below examples are presented in proportion with the entire material. Founded on this, we can presume that common people had not fully recognised the value of their old household commodities and folk costumes as cultural heritage. Arrogant and disdainful attitude towards old artefacts could be encountered considerably more frequently and sometimes the collectors themselves fell under the influence. The aim of the activity was incomprehensible to people and it often remained so also after detailed explanations.

\section{Pro}

But it was namely these old men and women who still wear folk costumes, who refused to give me a stitch of their clothing, either by donating or by selling. The master of Lauri farmstead only promised that, when he died, his folk costumes would be donated to the Estonian National Museum. (TAp 66, w/o number) 


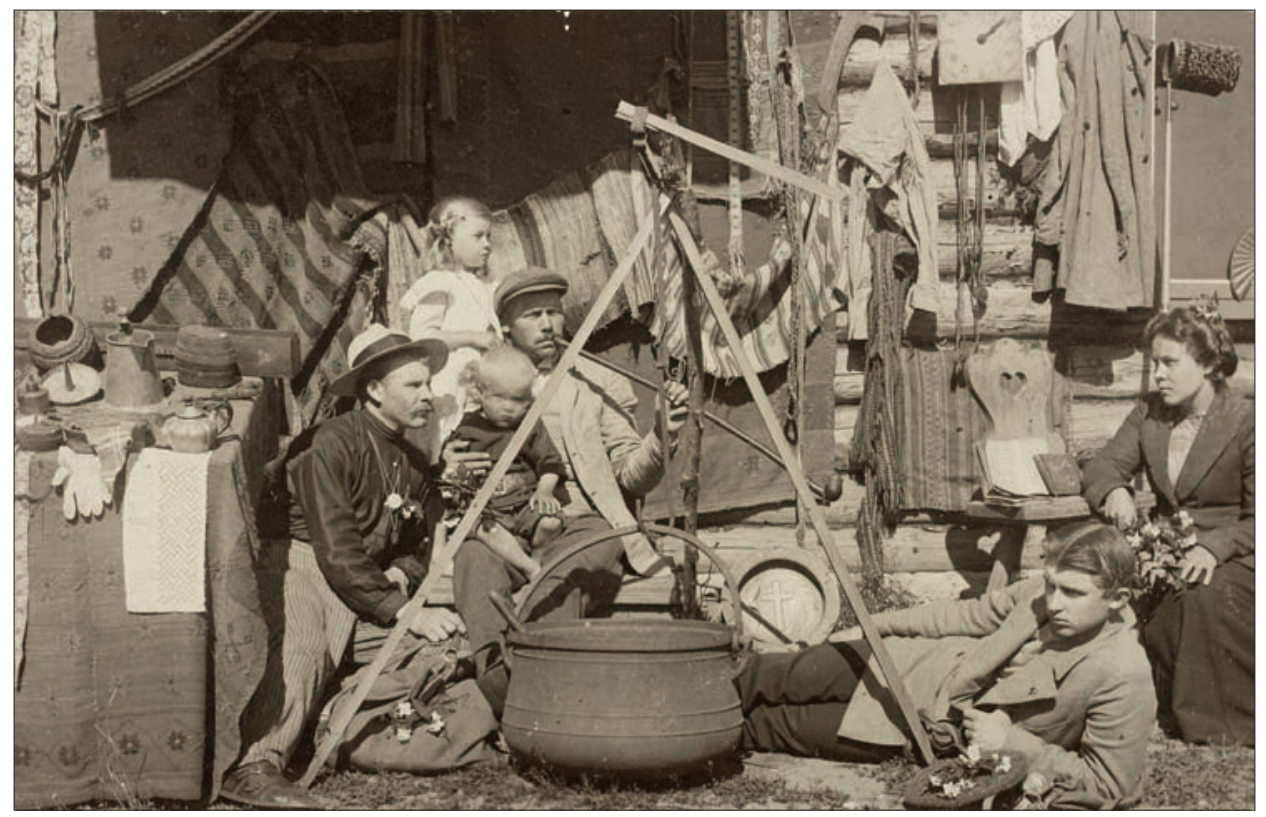

Figure 3. Heritage collectors with obtained artefacts in Kadrina in 1914. ERM Fk 362:70.

At Tahkuranna, people willingly showed us their old garments, explaining that this skirt had been woven by the granny herself and that coif, God knows from which generation, was godmother's present, etc. However, they were all carefully put back into the chest again. And when we wanted to have them for the museum, they started [---] to plead with us. "Dearies, please don't ask, you cannot buy memories for money; Mother wouldn't ask me to come to her funeral this way...”, etc. (TAp 15: 5)

In the whole parish, only three people cherished their old family relics so much that they decided not to part with them. (TAp 5: 44)

As soon as we had explained to a farmer's wife that we wanted the things for a kind of permanent display, for a museum, we heard: "How could I discard my mother's relics; let them better be in the chest, at least I can sometimes have a look at them myself," and the chest lid was slammed shut, so that we had nothing else to do but bid a sad farewell to these things. (TAp 94: 1) 
In the whole parish, I found only one family, whose hundred-year-old garments looked quite new; for example, a man's jacket, which I was barely able to get hold of. However, they wouldn't give me the so-called iron vest ${ }^{10}$ and the shortcoat. The man was even ready to let go of it, but the woman wouldn't. She said that she was an Estonian and she also wanted her children to be Estonians. The iron vest and the shortcoat were supposedly the best means to achieve it. In Tartu they may survive, maybe even forever, but Hiiumaa is far away and a trip to Tartu is expensive, so that one cannot count on being able to show these things to one's children there. I suggested she could sell the old things to the museum and for this money make new ones. However, she didn't think it was possible either. She said it was just like giving a hungry person a stone instead of bread. I didn't insist any more. It is really good if a person is in such a disposition that she sees her forefathers and foremothers and their souls in the garments, finds consolation, spiritual improvement and companions in bad luck in them, and would not give away these precious things of spiritual value for money. I made her promise that, when her children obviously seemed to be Estonians already, she would bequeath her garments to the Estonian National Museum in her will. (TAp 39: 2-4)

An expensive thing in Hiiumaa is the seppel (chaplet), a bride's headdress. If you happen to have it, you can get one rouble if you lend it out to a bride. Therefore, they ask a high price for it, five to ten roubles. I encountered a woman who was not well off, or maybe just short of money at the moment. And although she sold me her foremothers' inheritance, she cried when she had to depart from it. So I felt as if I had killed the old woman's ancestors by making this purchase. (TAp 39: 4)

On one farmstead, we found a tankard decorated with various patterns, and the farmer wanted to give it to the museum; yet, his wife pulled it out of his hand and said: "Do you think you will become honest again by giving it away?” (TAp 169: 21)

\section{Contra}

Naestevälja village is in the woods and far away from the others; despite this, there are no old things there. Everything was destroyed already 20 years ago. (TAp 65, w/o number) 
An old female cottager even grabbed a cudgel when she understood what I wanted, and said: "What should ragmen do if such gents start picking rags? Beat it!” (TAp 66, w/o number)

It's a pity we couldn't make this trip to Tahkuranna ten years sooner; we would have found a lot more then. Jews ${ }^{11}$ had devastated it all, taking silver brooches, bracelets, and so on. Garments and other things that were no good for them had been collected for the Pärnu Museum. (TAp 15: 4)

After long explanations they finally believed that the museum really existed; yet, they didn't understand why such old things were collected for it. A common question was: "Why such educated gents collect these old things; you could easily buy them from rag-and-bone men?"And then we had to explain, over and over again, what the difference was between the museum and a rag-and-bone man, and so on, which by the evening exhausted both our feet and voices. (TAp 136: 5)

$\ddot{A} k s i$ must be one of the most educated parishes and, therefore, also poor in old artefacts, as our educational system did not teach people how to respect themselves, their homeland and their mother tongue. (TAp 63: 5)

In another place, an old woman called Kettu, who had an old tankard, tried to warn us: "How do such handsome gents like you dare to collect such tacky old things; you wouldn't dare to pass through the village with this, someone is going to chase you with a cudgel.” (TAp 5: 43)

An old corvée-time man (Andres Pede) had a very peculiar opinion about heritage collection: "Well, I can't understand why you are collecting these old things; do you want to bring back old times? You go to the emperor and show him how people used to live and how they are flaunting now." [We explained to the old man that this was not the case.] (TAp 5: 46)

Jewellery, especially silver brooches and the like, having gone out of fashion, had been sold to the Jews or exchanged for something else in town. (TAp 4: 1-2)

Local agricultural associations (in Vigala and Märjamaa) contributed significantly to the destruction. So, for example, couple of years ago the Vigala Agricultural Association organised an exhibition sale. Like always, collectors were sent out, and they went from one farm to another, looking 
for artefacts. Within this process, as the members of the association told us, they also happened to lay their hands on items of heritage, such as wedding tankards, women's clothing, headgear, olden tools, etc. Quite often you could hear: we used to have fancy wedding tankards, but we gave them away - for the exhibition. And nothing good happened to the things that had been given for the exhibition. (TAp 94: 7)

An old woman was seriously worried about my brains: how could a sane person waste time and spend money on collecting old trash. (TAp 110: 6)

There are also places where people look disdainfully at olden things. So a farmer's daughter (M. Eller) told us that she had burnt a 200-year-old ornamented cupboard just because young people visited their farm and this old thing was really "ugly". (TAp 5: 44)

However, sometimes we encountered opposing opinions within the same family. An aged man sells us the Bible dating from 1731. His wife vehemently objects to this, saying that it is a forefathers' keepsake, with all the ancestors' names and birthdates written down on the cover. The man, who seems to be open-minded and rational, copies the family chronicle on the cover of a calendar and trades with us for the book. (TAp 75: 6)

Translated by Tiina Mällo

\begin{abstract}
ABBREVIATIONS
ERM EAV - Ethnographic Archive of the Estonian National Museum ERM Fk - Photographic collection of the Estonian National Museum TAp - Topographic Archive diary
\end{abstract}

\title{
NOTES
}

1 Estophiles are people not of Estonian descent who are sympathetic to or interested in the Estonian language, literature and culture, history, and Estonia in general; especially Baltic-German scholars who in the late 18th to early 19th century began documenting and promoting the Estonian language and culture.

2 Jakob Hurt (1839-1907) was an Estonian folklorist and linguist, pastor and public figure. 
3 The Learned Estonian Society, founded in 1838; German: Gelehrte Estnische Gesellschaft, (GEG), closed down in 1950 and re-established in 1988, is the oldest scientific society in Estonia.

4 The Estonian Students' Society is a student organisation established in Tartu in 1870. In 1940, after the Soviet Union had occupied Estonia, all student organisations were closed down. The ESS continued its activity as an underground organisation. Beginning in 1945, the ESS operated openly in exile (Sweden, Germany, Australia, Great Britain, Canada, the USA and Argentine). In 1988, the Estonian Students' Society was re-established in Tartu.

5 Oskar Philipp Kallas (1868-1946) was Estonian folklorist and diplomat.

6 The construction of a special museum building for the Estonian National Museum started in spring 2013.

7 With an official name: Stieglitz St. Petersburg State Academy of Art and Industry.

8 Gustav Suits (1883-1956) was an Estonian poet and literary critic.

9 Rasmus Kangro-Pool (December 20, 1890 - May 9, 1963) was an Estonian literary, art and theatre critic.

${ }^{10}$ A thick felted (probably grey) woollen vest.

${ }^{11}$ Peddlers of Jewish origin travelled the country, trying to buy up old artefacts, and especially silver jewellery, at a bargain price.

\section{ARCHIVAL SOURCES}

\section{Topographic archive of the Estonian National Museum}

TAp 4 = Gustav Wilbergi aruanne Eesti Rahva Muuseumi heaks asjade korjamise üle Kolga randades Kuusalu kihelkonnas 1910.a. suvel. [Gustav Wilberg's report on collecting artefacts for the Estonian National Museum on the coast of Juminda Peninsula, Kuusalu parish, in the summer of 1910.] Report dated 18.09.1910, $10 \mathrm{pp}$.

TAp 5 = Üliõpilaste J. Kompuse ja O. Kuriksi aruanne ainelise vanavara korjamise kohta Rannu kihelkonnas 1910 aastal. [Report on the collection of material heritage by students J. Kompus and O. Kuriks in Rannu parish in 1910.] 50 pp.

TAp 15 = Vanavarakorjaja Voldemar Lindpere reisikirjeldus 1911. a. [Heritage collector Voldemar Lindpere's travel report from 1911.] $5 \mathrm{pp}$.

TAp 39 = E. Michelsoni ainelise vanavara korjamise aruanne ( $\mathrm{k} / \mathrm{r} 61$ juurde) 1912.a.

[E. Michelson's report on the collection of material heritage from 1912.] $9 \mathrm{pp}$. 
TAp 63 = Marie Heibergi aruanne vanavara korjamise üle Äksi kihelkonnas 1912. a. mais. ERMi k/r 68 juurde. [Marie Heiberg's report on the collection of material heritage in Äksi parish in May 1912.] 5 pp.

TAp 65 = Korjaja Georg Grossi päevaraamat (diar 11). 8.06.-25.06.1913. a. Ambla kihelkond. [Collector Georg Gross's diary. Ambla parish, June 8-25, 1913.] 30 pp.

TAp 66 = Vanavarakorjaja A. Kasekampi mõned täiendavad märkused vanavara korjamise kohta. Alustatud 21. aprillil 1913. [Heritage collector A. Kasekamp's supplementary remarks on heritage collection. Started on April 21, 1913.] 5 pp.

TAp 75 = Albert Saabergi päevaraamat vanavara korjamisel 11.05.-22.05 1913. a. Jüri kihelkond. [Albert Saaberg's diary at heritage collection on May 11-22, 1913; Jüri parish.] 7 pp.

TAp 94 = Korjajate A. Reiniku ja J. Grünbergi vanavara korjamise aruanne Märjamaa kihelkonnas. 1. juuni-15. juuli 1913. a. [Report on the collection of material heritage by A. Reinik and J. Grünberg in Märjamaa parish. June 1 - July 15, 1913.] $11 \mathrm{pp}$.

TAp 110 = Eesti Rahva Museumi asjade korjaja A. Kruusbergi lühike reisikirjeldus. (Suvel 1913.) [Short travel report by A. Kruusberg, collector of the Estonian National Museum. (Summer of 1913.)] 8 pp.

TAp 136 = J. Tenteri ja A. Lehe vanavarakorjamise aruanne 1914.a. Juuru kihelkond. [Heritage collection report by J. Tenter and A Leht, Juuru parish, 1914.] 23 pp.

TAp 169 = Ed. Depmani vanavara korjamise aruanne Viljandimaal ERM k/r 309 juurde. 1914 ja 1915. a. Viljandi ja Paistu kihelkond. [Ed. Depman's heritage collection report in Viljandimaa to collection register 309. 1914 and 1915, Viljandi and Paistu parishes.] 29 pp.

\section{Ethnographic Archive of the Estonian National Museum: Miscellaneous}

Matto = Gustav Matto. Kristjan Raud - eesti vanavara kogumise suurmehi. Tema 100-ks sünnipäevaks. [Kristjan Raud: Grand old man of Estonian heritage collection. 100th birth anniversary.] ERM EAV 16:2.

\section{REFERENCES}

Jansen, Ea 2004. Vaateid eesti rahvusluse sünniaegadesse. [Insights into the Birth Period of Ethnic Estonian Nationalism.] Tartu: Ilmamaa.

Jansen, Ea 2007. Eestlane muutuvas ajas: seisusühiskonnast kodanikuühiskonda. [Estonians in a Changing World: From Estate Society to Civil Society.] Tartu: Eesti Ajalooarhiiv. 
Jansen, Ea 2010. Kultuuriline murrang. [Cultural Upheaval.] In: S. Vahtre \& T. Karjahärm \& T. Rosenberg (eds.) Eesti ajalugu V. Pärisorjuse kaotamisest Vabadussõjani. Tartu: Ilmamaa, pp. 382-395.

Kallas, Oskar 1923. Eesti rahva muuseumi algaegadelt 2. [From the Initial Years of the Estonian National Museum.] Newspaper Postimees, No. 158, June 17, p. 4. Available at http://dea.nlib.ee/fullview.php?pid=s208963\&nid=46795\&frames et=1, last accessed on June 3, 2014.

Kangro-Pool, Rasmus 1923a. Rahvariie. [Folk Costume.] Newspaper Päevaleht, No. 224, August 25, p. 8. Available at http://dea.nlib.ee/fullview.php?pid=s402534\&nid=2 67509\&frameset=1, last accessed on June 3, 2014.

Kangro-Pool, Rasmus 1923b. Rahvariie. [Folk Costume.] Newspaper Päevaleht, No. 225, August 26, p. 4. Available at http://dea.nlib.ee/fullview.php?pid=s402535\&nid=2 67510\&frameset=1, last accessed on June 3, 2014.

Kangro-Pool, Rasmus 1961. Kristjan Raud ja Eesti Rahva Muuseum. [Kristjan Raud and the Estonian National Museum.] In: R. Kangro-Pool (ed.) Kristjan Raud 1865-1943. Tallinn: Eesti NSV Kunst, pp. 66-84.

Kannike, Anu 1994. "Rahvuslik" rahvakultuur/ "National" Folk Culture. Pro Ethnologia, Vol. 2. Tartu: Eesti Rahva Muuseum, pp. 7-29. Available at http://www.erm.ee/ pdf/PE2.pdf, last accessed on June 3, 2014.

Karjahärm, Toomas 2010. Eestlus ja eurooplus. [Estonianness and Europeanness.] In: S. Vahtre \& T. Karjahärm \& T. Rosenberg (eds.) Eesti ajalugu V. Pärisorjuse kaotamisest Vabadussõjani. Tartu: Ilmamaa, pp. 379-380.

Karjahärm, Toomas \& Sirk, Väino 1997. Eesti haritlaskonna kujunemine ja ideed 1850 1917. [Formation of Estonian Intellectuals and Their Ideas in 1850-1917.] Tallinn: Eesti Entsüklopeediakirjastus.

Kiho, Toomas 2013. Saagem eurooplasteks, kuid ärgem jäägem eestlasteks. [Let's Become Europeans but not Remain Estonians.] Akadeemia, Vol. 3, pp. 387-400. Available at http://digar.nlib.ee/digar/show/?id=130698, last accessed on June 3, 2014.

Kohalikud sõnumid 1894 = Kohalikud sõnumid. [Local News.] Newspaper Postimees, No. 140, June 30, p. 3. Available at http://dea.nlib.ee/fullview.php?pid=s333184 \&nid=3186\&frameset=1, last accessed on June 3, 2014.

Laar, Mart 2010a. Rahvuslus ja eelärkamisaeg. [Nationalism and Pre-Awakening Period.] In: S. Vahtre \& T. Karjahärm \& T. Rosenberg (eds.) Eesti ajalugu V. Pärisorjuse kaotamisest Vabadussõjani. Tartu: Ilmamaa, pp. 219-233.

Laar, Mart 2010b. Ärkamisaja algus. [Beginning of the Awakening Period.] In: S. Vahtre \& T. Karjahärm \& T. Rosenberg (eds.) Eesti ajalugu V. Pärisorjuse kaotamisest Vabadussõjani. Tartu: Ilmamaa, pp. 234-245.

Manninen, Ilmari 1923. Rahvariietest: Pro et Contra. [About Folk Costumes: Pro et Contra.] Newspaper Päevaleht, No. 238, September 8, p. 8. Available at http:// dea.nlib.ee/fullview.php?pid=s402550\&nid=267526\&frameset=1, last accessed on June 3, 2014.

Pino, Veera 1998. O. Kallase noorusaeg ja õpingud. [Youth and Studies of O. Kallas.] In: K. Aru (comp.) \& S. Olesk (ed.) Oskar Kallas. Artikleid Oskar Kallase elust ja tööst. [Oskar Kallas: Articles about Oskar Kallas's Life and Work.] Tartu: Eesti Kirjandusmuuseum, pp. 13-66. 
Raud, Kristjan 1909. Eesti Rahva Museum. Ainelise vanavara korjamisest. [About Collecting Material Heritage.] Newspaper Postimees, No. 126, June 10, p. 1. Available at http://dea.nlib.ee/fullview.php?pid=s232539\&nid=5911\&frameset=1, last accessed on June 3, 2014.

Suits, Gustav 1905. Noorte püüded. Üksikud mõtted meie oleviku kohta. [Strivings of the Youth.] Noor-Eesti I. Tartu: Kirjanduse Sõprade Kirjastus, pp. 3-19.

Summatavet, Kärt 2007. Mõningaid mõtteid kunstist, Kristjan Rauast ja vanavara kogumisest. [Reflections on Art, Kristjan Raud and Collecting Tangible Heritage.] Mäetagused, Vol. 37, pp. 7-44. doi:10.7592/MT2007.37.summatavet.

Uuemad sõnumed 1893 = Uuemad sõnumed. [Recent News.] Newspaper Olevik, No. 45, November 8, pp. 960-961. Available at http://dea.nlib.ee/fullview.php?pid=s375 $338 \&$ nid=112407\&frameset=1, last accessed on June 3, 2014.

Viires, Ants 2001. Kultuur ja traditsioon. [Culture and Tradition.] Tartu: Ilmamaa.

Vunder, Elle 2003. Moderniseerumine ja kultuurimustrite muutused Eestis 19.-20. sajandil. [Modernisation and Changes in Cultural Patterns in Estonia in the 19th-20th Centuries.] Eesti Rahva Muuseumi aastaraamat XLVII. Tartu: Eesti Rahva Muuseum, pp. 47-70.

Vunder, Elle 2008. Agraarühiskond ja rahvakultuur. [Agrarian Society and Folk Culture.] In: A. Viires \& E. Vunder (comps.) Eesti Rahvakultuur. Tallinn: Eesti Entsüklopeediakirjastus, pp. 65-71. 


\section{NEWS IN BRIEF}

\section{MARE KÕIVA 60}

On February 26, Mare Kõiva, one of the greatest authorities on Estonian folk belief and folklore, leading researcher at the Estonian Literary Museum, Head of the Department of Folkloristics, celebrated her 60th jubilee.

After finishing her literature-biased studies at Elva Secondary School, Mare entered the University of Tartu in 1973, and graduated from the Department of Estonian Philology, specialising in folklore, in 1979. As a student, she worked as assistant at the folklore section of the then Institute of Language and Literature. In 1985-1988, she undertook her post-graduate studies at the same institute, and after completion continued there as a researcher under the supervision of Ülo Tedre, defending her thesis titled Estonskie zagovory. Klassifikatsiia i zhanrovye osobennosti (Estonian Incantations: Classification and Genre Specifics) in 1990.

After the defence, Mare Kõiva continued as senior researcher and head of folk belief study group at the Department of Folklore of the Institute of the Estonian Language and Literature (after reorganisation in 1993, the Institute of the Estonian Language).

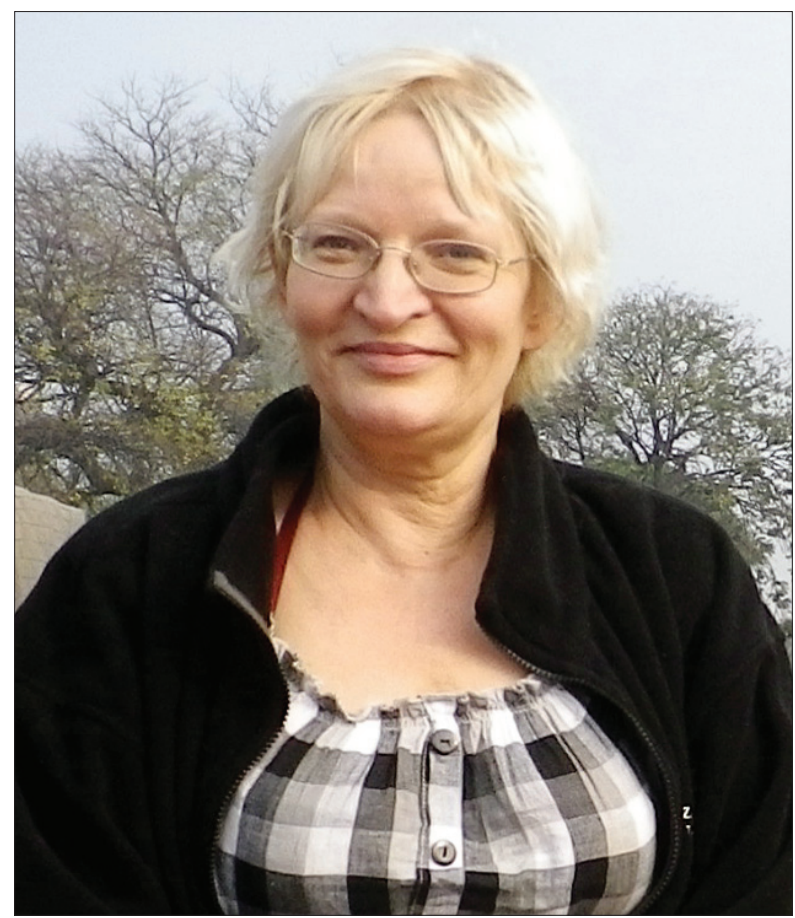

Photograph from private collection. 
When the folklore department of the Institute of the Estonian Language merged with the Estonian Literary Museum in Tartu in 2000, Mare became Head of the Department of Folkloristics at the museum, as well as leading researcher of the folk belief and media study group.

Mare's working capability and dedication to work are extraordinary; as she herself often says: "A folklorist is on the alert seven days a week and twenty-four hours a day." Mare and folklore are so tightly knit together that her working life cannot be separated from her private life. Besides being a mother of five grownup children, she is also an efficient folklorist, who is among the last to leave the museum before it closes late in the evening. It is quite typical of her that she also spent her 60th jubilee among the folklorists' community in the Witch's Country in Uhtjärve primeval valley, where her birthday was marked with the Estonian folklorists' 9th Winter Conference on February 26 and 27, this time under the heading "Folklore and Coherence". The conference brought together researchers from Estonia, Lithuania, Latvia, Finland, Hungary and Russia - Mare's good academic friends, who dedicated their presentations to the wide range of research topics that the jubilarian has ever studied. The latter involve, for instance, folk belief, folk medicine, folk astronomy, archaeology, Internet lore, culture of expatriated Estonians and minority groups, and contemporary folklore. When supervising the research of the whole department, she has always tried to be ahead of time, inspired her colleagues and encouraged them to be interdisciplinary and cooperate on an international level. Mare's spheres of interest, knowledge and methodological approaches are extensive, and she has a good eye for detecting new cultural phenomena.

During her thirty-five years of working life, Mare has shown herself as an ardent promoter of folkloristics, a courageous experimenter and initiator of numerous ides. It was on the initiative of Mare and her colleagues-adherents that the Estonian server of folkloristics, Haldjas (http://www.folklore.ee), started to evolve, and has today become one of the most extensive and idiosyncratic folklore servers in the world, covering large databases of the lore of Estonians and other Finno-Ugric peoples, electronic publications and information about folklorists and research institutions.

Mare has assisted many colleagues in publishing their books, and established two internationally recognised journals of folkloristics - Mäetagused: Hüperajakiri and Folklore: Electronic Journal of Folklore - the first issues of which saw the light of day in 1996 and have continued under her editorship throughout eighteen years. Mare has also initiated series of publications titled Tänapäeva folkloorist (On Modern Folklore) and Sator, and in 2011 she was at the birth of a new international journal Incantatio: An International Journal of Charms, Charmers and Charming. She has authored tens of researches and publications, and at the winter conference her latest collection, Through the Ages I: Folklore as a Common Expression of Lingual, Figurative, Emotional and Mental Memory (Sator 5), was presented, which is comprised of articles covering a wide range of topics, written by her in different time periods.

Among the highlights of her work are Eesti loitsud (Estonian Incantations), published in 2011 on the basis of the material of her thesis, database Rehepapp of folk belief and legends, database Berta of Estonian popular calendar festivals, south-Estonian tradition portal LEPP, and a database on lumbago. Mare has also initiated a number of extensive collection campaigns (for example, all-Estonian school lore collection competitions in 
1992 and 2007) and authored numerous television and radio programmes on folklore and folk belief.

Mare is a member of many institutional (scientific) councils, editorial boards of international publications, as well as international professional associations and working groups. International cooperation fills a considerable part of her summers, which are dedicated to conferences and fieldwork, as well as writing or editing articles, usually several at a time. She has also supervised a number of master's as well as doctoral theses.

Mare's contribution to Estonian national culture is considerable; she has made endless efforts to advocate folkloristics, delivering lectures to teachers, astronomers, schoolchildren, pensioners, and others in schools, different courses and county libraries. As an eloquent speaker, she is in great demand and fails to refuse even if she has no time for it. Her colleagues admire her initiative, working capacity and scope of interests; yet, they also know that in recent decades administrative work has consumed a great deal of her energy, often at the expense of creative work.

On August 26, 1991, while on a fieldwork expedition in Torma parish, Mare wrote in her diary: "How little a folklorist needs to be happy - one really wonderful story and you already sprout wings!" May there be plenty of beautiful stories to come to instigate your folkloristic activities! We wish you all the happiness, tenacity and good health, so that you could initiate and realise all your spirited ideas!

Piret Voolaid

\section{“FRIENDS, THOUGH ABSENT, ARE STILL PRESENT"}

The ancient proverb "Friends, though absent, are still present", already known to that great rhetorician Cicero, is a perfect piece of folk wisdom to describe the deep and lasting friendship between Arvo Krikmann at Tartu, Estonia, and myself at distant Burlington, Vermont, in the northeastern corner of the United States. One might well ask how we two folklorists and paremiologists became acquainted, and yet, it is well known that scholars with similar interests are bound to find each other, no matter where they happen to live in the world. By way of discovering each other's published work, a keen interest to communicate with the respected and admired colleague arises that will quite naturally result in an epistolary relationship, an exchange of publications, meetings at international conferences, and over time a sincere friendship that is not hindered by the thousands of miles between the two residences and work places.

This kind of rite of passage certainly happened to Arvo Krikmann and me, even though it took many years for us to finally meet in person. Arvo, being five years older than I am, has always been a few steps ahead of me in age and accomplishments. It was thus quite natural that at the beginning of my professorial career he was of an immense 
influence on me. I will never forget when I came across his seminal publication, titled On Denotative Indefiniteness of Proverbs (1974), and its addendum, Some Additional Aspects of Semantic Indefiniteness of Proverbs (1974). A decade later I had the honor to republish both of them in Proverbium: Yearbook of International Proverb Scholarship (1984 and 1985), and the invaluable insights on the polyfunctionality, polysituativity, and polysemanticity of proverbs presented in them have influenced me and others during the past forty years. It is with so much joy and delight that I tell my folklore and proverb students that Arvo Krikmann is not only a world-class scholar, but he also happens to be my very special friend. I also explain to them that it is such deep friendships that make scholarship so special, for scholarly research without the support and interest of friends is like working in a lifeless vacuum. Of course, I also give my students Arvo Krikmann's book Proverb Semantics: Studies in Structure, Logic, and Metaphor (2009) as a present. I had edited this volume comprised of eight invaluable articles by Arvo as a present to him on his seventieth birthday. The book has a cover illustration that shows both of us at the Second Interdisciplinary Colloquium on Proverbs at Tavira, Portugal, in November 2008. The students have told me that this picture and my introduction have made it clear to them what friendship means in the scholarly world.

The political situation during the long period of the Cold War did not permit us to meet each other for many years, but I simply took the liberty to send book packages to

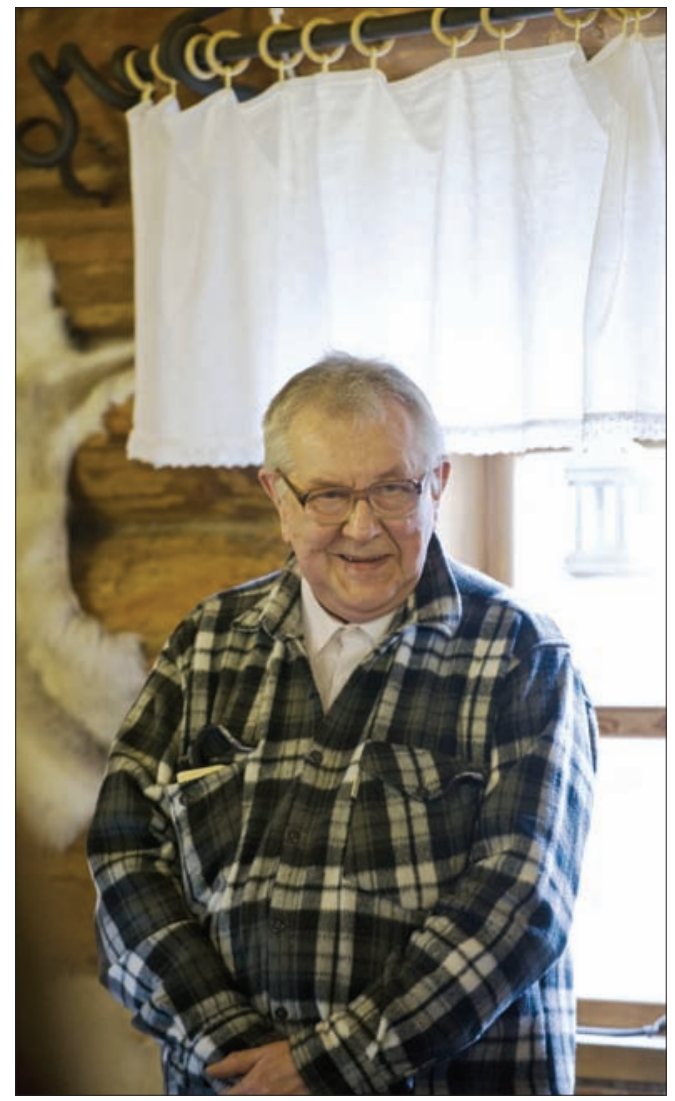

Tartu that included new paremiological publications and the annual Proverbium volumes. The Iron Curtain as well as the fact that I cannot communicate in Estonian and that Arvo was reluctant to use his excellent knowledge of the English language kept us from entering into a state of frequent communication with each other. And yet, both of us felt that there was a natural bond between us as kindred spirits. I know that my thoughts often wandered to Tartu when I was once again quoting Arvo in one of my books or articles. And he celebrates his 75 th birthday. 
has subsequently told me that he, too, would sit at his desk wondering what Wolfgang would think of his newest publication. It is easy to imagine the joy we both felt when a package would arrive with a major scholarly achievement, to wit, the five massive and invaluable volumes of Eesti vanasõnad (1980-1988).

The ice was broken when Arvo sent me a letter on November 29, 1993, with the following heart-warming declaration: "Wow, when the iron curtain has ceased to exist and our shock of freedom lived through as well, it is obviously the ultimate hour for me to break the silence, to convince you that rumors about my death are strongly exaggerated, to thank you for the literature you have sent us (bibliographies, Proverbium, Vols. 1-10, etc.), and, also, to offer some collaboration.” And on December 10, 1993, I responded with much excitement: "Thank you so much for writing. I was always a little disappointed that you never responded to getting Proverbium, but I understood the political situation, of course! Now we should be able to communicate from time to time. I treasure and respect and admire your theoretical work!" With these two letters we began our correspondence, and we both treasure these epistles that have amassed to well over five hundred pages during the past twenty years. They are a lasting testimony of our close friendship and sincere interest in each other's work.

And then, finally, another ten years later, in 2004, the time had come for us two paremiological work-horses and epistolary friends to meet in person at an international meeting commemorating the Lithuanian paremiologist Kazys Grigas at Vilnius. We were almost like two little children waiting for a big birthday or Christmas present! Almost poetically Arvo wrote to me on January 30, 2004: "Some little Lithuanian birds have chirped that you aim to fly to Vilnius and participate in the memorial conference for Kazys Grigas on March 5, 2004. Please, let me know if it is true. If it is, then I seem to have got, better late than never, a happy chance to meet you in the flesh. What a miracle, what a miracle! If we really meet, may I take with me some newer Estonian books for you, or do you prefer to get them by post?" I responded on the same day (e-mail makes it possible!), by employing Arvo's "bird"-metaphor as well: "YES, the little bird has spoken the truth. I will indeed come to Vilnius - a big reason is wanting to meet you and some of the other dear friends from Eastern Europe. I am so much looking forward to meeting you finally. Yes, I could carry a couple of books back to America. But please remember, the suitcase holds only so much. I will see you soon, my dear friend. Who would ever have thought that this glorious day would happen? Now it is here!" Rereading these excerpts still brings tears to my eyes. My proverb students, to whom I have read a few of these letters, have told me that they helped them to understand what I meant by telling them about the importance of friendships among professors.

In July 2005, the 14th Congress of the International Society for Folk Narrative Research took place at Tartu, and this gave me the opportunity to visit Arvo and his dear wife Luule in that beautiful Estonian city. Those summer days belong to some of my fondest memories, and I so much enjoyed my time together with Luule and Arvo in their beautiful home. Here are some touching words that my friend Arvo wrote to me on August 16, 2005, after I had returned to the United States: "All the first week of August I could not get you out of my head and mind and heart and memories. Everything I told Luule was so exclusively about you that she finally asked if everything was okay with me. Though, to be honest, she herself suffered from the same disease as well. It is very 
hard for me to believe that such sunny beings can exist, without any black holes in their souls, without any skeletons in their closets, absolutely unable to do bad deeds, say bad words or think bad thoughts. Please forward to your dear Mrs. Barbara our cordial thanks for her greetings and also the very best wishes from both Luule and me." My response on the same day echoed these feelings: "Thank you, thank you for your wonderful letter! I was so deeply touched by your kind words, expressing the same feelings that I have had ever since I saw you at Tartu. We really did spend a lot of memorable time with each other, and I feel that we have all become very close friends. I keep thinking how it would be if we could have worked together on proverbial matters for the past decades! Imagine what we could have accomplished together. We obviously have the same work ethics and the same enthusiasm for our work. There is no doubt, Kriku, that you are one of my heroes! I have so much admiration for you personally and also for your incredible scholarship. It is no surprise to me any longer that you have received many prizes and that you are one of the academy members. You deserve all of this, and I am so proud to be your colleague and friend. Barbara too has observed that I talk a great deal about both of you. I think that Kriku has taken over the role of Alan Dundes [he died on March 30, 2005] in my life. You know how much he meant to me, and I feel less lonely now that I know that you are in my life. Thank you for helping me deal with my loneliness. Here is wishing you both and your family the very best. My thoughts are often with you at Kastani 59! Barbara sends her love as well, and she hopes that she will also meet you in the future."

Wolfgang Mieder 


\section{PRESIDENT'S FOLKLORE AWARD AND FOLKLORE COLLECTING IN 2013}

On February 28, 2014, Toomas Hendrik Ilves, President of the Republic of Estonia, handed out folklore collection awards at the Estonian Literary Museum. The best collectors were recognised for their good work with letters of gratitude and keepsakes, and a competition for the collection of local lore was announced. This year the President's folklore award went to Hillar Palamets, Ado Seire and Terje Puistaja.

Hillar Palamets, a historian and educator, renowned for his good narration skills, has authored several books and radio programmes; for example, a series called 'History

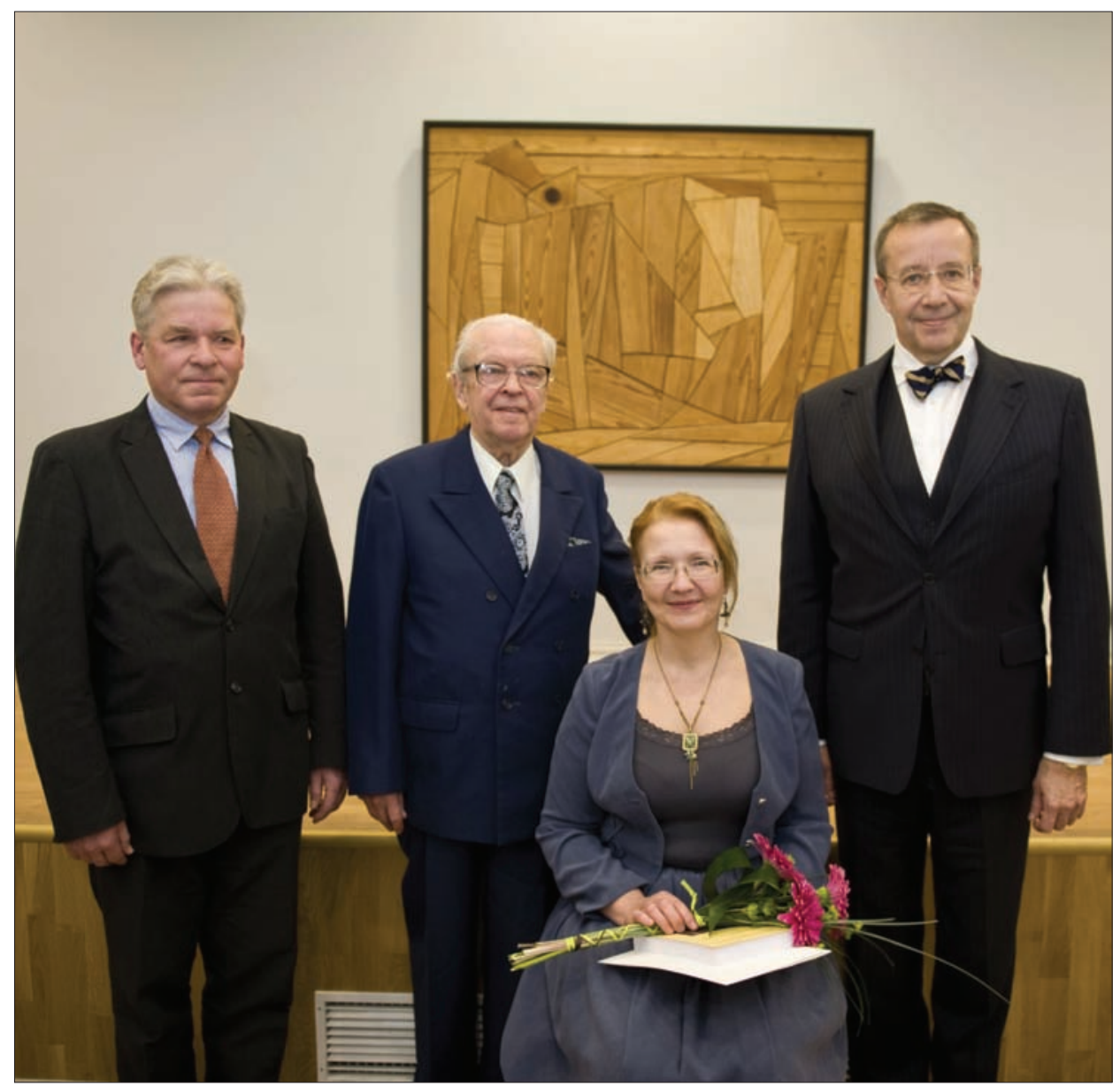

Laureates of the President's folklore collection award with the President. From the left: Ado Seire, Hillar Palamets, Terje Puistaja, President Toomas Hendrik Ilves. Photograph by Alar Madisson 2014. 
Class', which has lasted for 18 years. Since 1991, Hillar Palamets has nearly annually visited our museum, bringing us a notebook or an envelope full of sheets of paper filled with calligraphic handwriting. He has mediated his own and his family's traditions, donating to the archives his family's personal poem collections and photographs of festive occasions.

Ado Seire has collected village and place lore in one of the oldest Estonian villages Kareda village in Järva County - and its neighbourhood in the years 1994-2012. He has conducted interviews with 34 people, the materials of which are recorded on 68 cassettes. Part of the material is provided with detailed content descriptions and registers of place and personal names. The topics discussed involve several important events in which the inhabitants of Kareda village have participated and which are still remembered by the villagers: the Russian-Japanese War, the War of Independence, the First and Second World Wars. The interviewees also recall the history of Kareda village school and community centre, as well as the history of Esna, Kodasema, Õle, Öötla and Köisi estates, the Järva-Peetri parsonage and the church.

Terje Puistaja as a teacher of folklore and artistic production at the Estonian Folk Tradition School is in daily contact with heritage. Her studies for a master's degree are also related to folklore. Interviews conducted in Mahu village, which have been handed over to the museum, constitute a part of her studies. Terje Puistaja has carried out interviews with three generations of the same family. This family lore gives an overview of their traditions: weddings, funerals, remembrances of their kin and village people.

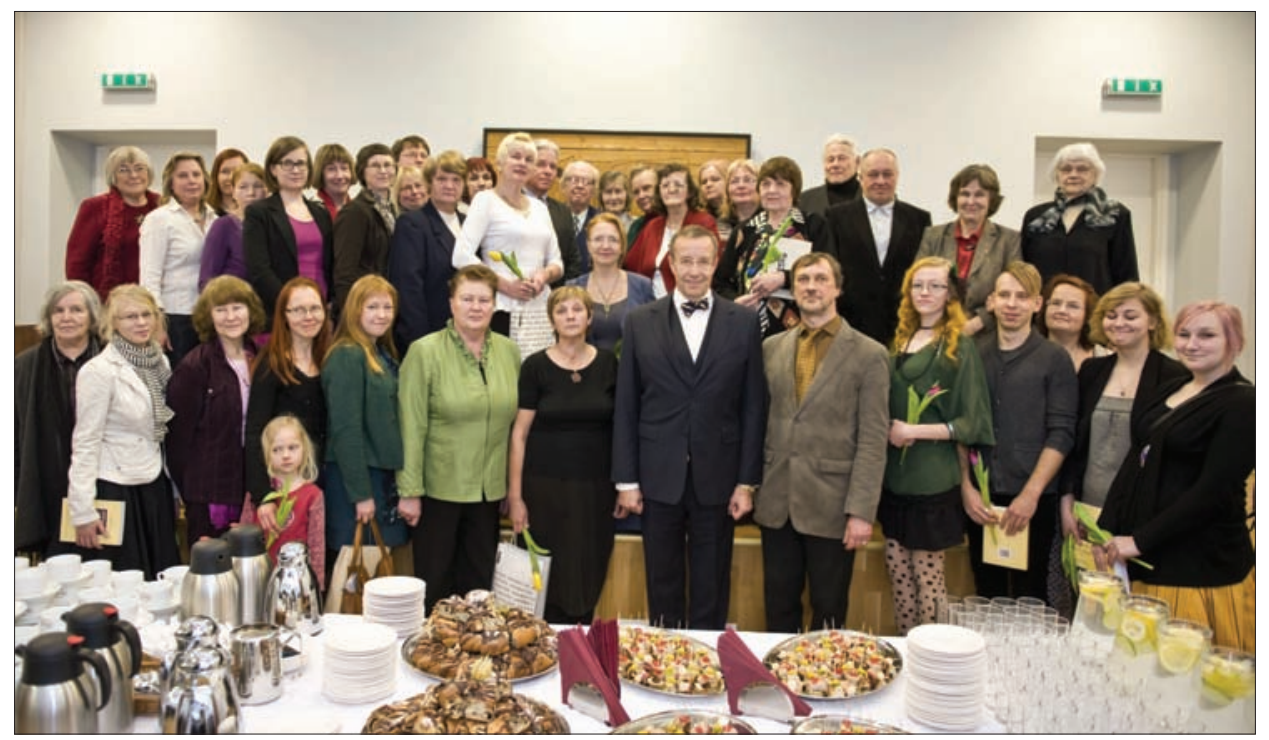

Participants of the collection competition for children's games, members of the jury, laureates of the President's folklore award and other folklore collectors with President Toomas Hendrik Ilves. Photograph by Alar Madisson 2014. 
There are 415 pages of transcripts written down from recordings, which in all make up 18 hours. Although many degree candidates collect material, Terje Puistaja has been the only one to arrange and systematise it so thoroughly that it could also be used by other people who are interested in this subject. Also, she has collected stories from the people who have had to do something novel in their lives. Her interviewees include, for example, Mikk Sarv, Mall Hiiemäe, Ingrid Rüütel, Ene Lukka, Malle Mutso, and others.

Although year after year the management of the Estonian Folklore Archives has become more and more complicated, the year 2013 for both the archives and many folklore collectors passed under the theme of games and play. Within the framework of the Heritage Year, a competition for collecting children's games was organised; yet, cooperation with folklore collectors continued in other spheres as well.

As a result of the efforts made by professional folklorists, university students and volunteers, the collections were considerably supplemented. The manuscript collection of the folklore archives increased by 4017 pages (61 volumes, 24 of them digitalised); the sound recordings collection obtained 343 new museals (2691 pieces altogether); the photographic collection was supplemented by 3188 frames and 64 film rolls. The Internet-based file repository Kivike currently includes descriptions of 20,613 museals from the folklore archives and 30,002 descriptions of music pieces, a third of which were added in 2013.

A major part of the incoming materials was place lore related sound recordings and digital photos from the fieldwork on Vilsandi Island and in Matsalu, and the lore of Lau village in Juuru parish, which were handed over by the place lore working group of folklore archives. Material was also obtained from Anu Korb, who carried out fieldwork at the Estonians of Krasnoyarsk Krai, and from Helen Kõmmus, who made videos at the Viljandi Folk Music Festival.

Last year another innovation was introduced by the folklore archives: the collection module called Kratt, in which contributions, photographs and video files can be entered. We hope that this will facilitate the life of folklore collectors, as after logging in one can have a look into all the contributions, continue those pending and start new ones. In the archives the collection module facilitates the archiving of materials and communication with correspondents. Currently the module also includes materials of the collection competition of 2014, which is dedicated to the stories of our homes.

The competition for children's games collection within the framework of the Year of Cultural Heritage attracted 77 participants, who sent their childhood memories and descriptions of games on 650 pages, as well as photographs, drawings, paper board games, paper dolls, etc. Memory institutions have collected game descriptions also formerly, and they have been published as well. The peculiarity of this particular competition was that the participants were asked to describe the games through their own playing experience, which especially clearly manifests the influence of the era on children's activities.

The jury members of this competition were Mall Hiiemäe, Risto Järv, Kadri Tamm, Astrid Tuisk and Piret Voolaid from the Estonian Literary Museum, writer Tiia Toomet, the founder of the Tartu Toy Museum, Karin Konksi from the Estonian National Museum, and Heli Poolakese from the Tartu Toy Museum.

The jury decided to single out twelve best writers, to recognise another twelve, and award special prizes to eight participants. 


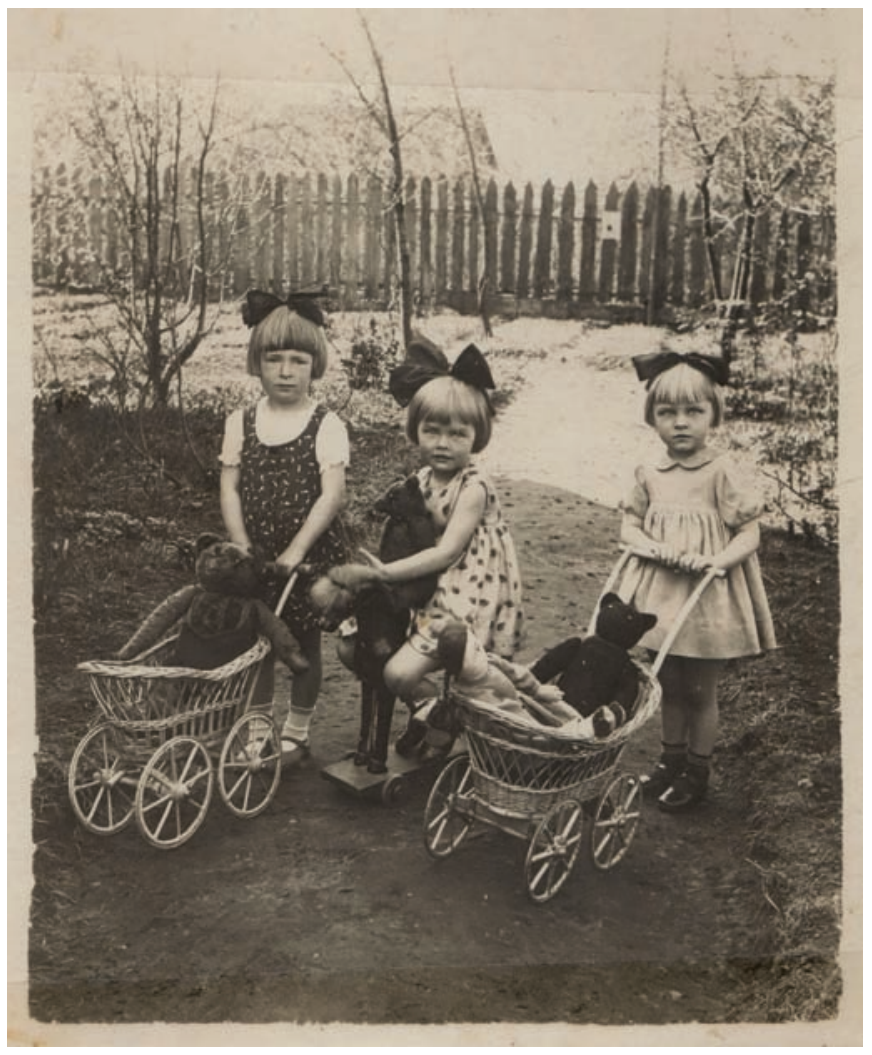

Girls-playmates in a yard in Kesk Street, Tartu. The house had a big garden with plenty of space for playing. Each girl had a doll, a teddy-bear, a doll's pram, and also a wooden horse on wheels. Photograph by Maie Erik sent to the collection competition of children's games.

The collection competition was financially supported by the Cultural Endowment of Estonia and the Year of Cultural Heritage; the prizes came from the Science Centre Ahhaa, the Ludo board game shop, and publishing houses Hea Lugu and Koolibri.

Astrid Tuisk 


\title{
BOOK REVIEWS
}

\section{ERA OF MEMES IN DIGITAL CULTURE}

\author{
Limor Shifman. Memes in Digital Culture. The MIT \\ Press Essential Knowledge Series. Cambridge: MIT \\ Press, 2013. 216 pp.
}

The most recent book by Limor Shifman, communication researcher at the Hebrew University of Jerusalem, is dedicated to the ongoing processes in digital culture. The author does not pose a question about what digital culture is. It is a sphere of life, the expressions of which are disseminated by way of digital media, i.e., computers, smartphones and computer networks. The components of digital culture (texts, pictures, videos, Internet language, behavioural practices and their representations) are usually created by means of relevant technology, or by intertwining digital and physical

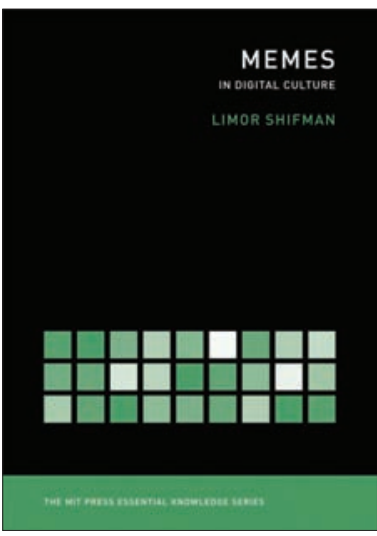
acts. The sphere also requires the existence of pre-digital materials on the Internet or other cloud repositories.

As strange as it seems to be, the reader can greatly benefit from being unspoilt by the "old" meme theory. Also, one should not expect the author to develop a folkloristic meme theory. The reader is provided with a clear definition of which memes are dealt with and what they are. If the analysis were a song, the meme definition would be the refrain deserving repetition and remembering. Limor Shifman defines the Internet meme as a group of digital items sharing common characteristics of content, form and/or stance, which were created with awareness of each other, and were circulated, imitated, and/or transformed via the Internet by many users (pp. 7, 41).

The issue of continuity with the original formulation of the meme concept contributed by Richard Dawkins, has instigated Henry Jenkins, a renowned theoretician of digital culture, who, after Limor Shifman's book had come out, published an interview with the author on his blog (see http://henryjenkins.org/2014/02/a-meme-is-a-terrible-thing-towaste-an-interview-with-limor-shifman-part-one.html\#sthash.doq7VMU2.dpuf). In the interview he asks Shifman to comment on the changes in the use of the meme concept in comparison to the $1970 \mathrm{~s}$. We learn that the focus is not on a single cultural unit that has propagated well, but groups of content units; not self-replicating culture but meaningful components of culture that are shaped and diffused by active human agents.

So, Shifman set herself an aim not to redefine the meme concept in its general sense, but to suggest a definition for the emergent phenomenon of Internet memes. Internet memes are user-generated concepts, which in digital culture denote products of an ongoing creative process. Part of this process is certainly sharing, continuous forwarding of memes, to which Limor Shifman devotes special attention in her book. In social media memes appear especially quickly, in a continuous flow; yet, blogs and possibilities offered by instant messaging protocols are not left aside either. Shifman regards as meaningful 
the fact that those who process and forward the material circulating on the Internet have adapted namely the meme concept: there is a fundamental compatibility between the term 'meme' and the way contemporary participatory culture works. The mediated content that passes along from person to person gradually scales into a shared social phenomenon, cultural information. In her interview to Henry Jenkins, Shifman avows that in this respect, Dawkins's formulation and contemporary participatory culture are in unison. Although the number of forwarders is much higher than that of those who reproduce basic images and launch new memes (and there are even more of those who just observe and rarely post), all individual participants are aware of what content is processed with which methods. As examples of the latter, the author of the book repeatedly mentions repackaging, imitation, remixing and mimicry - the main methods that give birth to or make go viral the products and reflections of the creative activity of Internet users.

Shifman presents and characterises nine meme genres: both those in the case of which the basic material and transformations proceed from the web, and those based on real-life moments or presupposing participation in specific physical action (pp. 99-118).

Another aspect I would like to emphasise in the context of this book review is that Shifman highlights and describes, besides the definition of the Internet meme, the existing meme genres. In chapter 7, the author presents vivid examples of each of them, which make the interested reader to google, in order to understand what is what. Interactive reading is also possible if you, following Shifman's well-elaborated logic, travel through the vernacular web searching additionally for relevant keywords, watch videos, read blogs and users' discussions about their own activity at the sites where Internet memes and viral phenomena are submitted by regular users (for example, http://knowyourmeme.com/).

According to Shifman, the nine meme genres are as follows:

Reaction Photoshops / photo processing - digitally altered photographs as comments on events and official news;

Photo fads - photos and videos (one of the most well-known examples is "planking"); Flash mob - a group of strangers gather in a public space and perform a particular act simultaneously. After that they just leave the scene (the Baltic Chain - see http:// www.balticway.net/index.php?page=baltic-way\&hl=en - has certain features of a flash $\mathrm{mob}$ ). Advertisers/advertising agencies have detected the power of such actions and organise flash mobs for marketing purposes;

Lipsynch - videos in which a person or persons try to match their lip movements to popular songs;

Misheard lyrics - funny mistranslation of spoken sounds or songs to written words; usually added in the subtitles of an existing video clip;

Recut trailers - the re-editing or remixing of film footage by the users;

LOLCats (lolspeak) - pictures of cats accompanied by systematically misspelled captions, which refer to the situation shown in the photo;

Stock character macros - so-called 'advice animals' macros: animal picture macros with absurd advice phrases as if uttered by a dog, penguin, wolf, frog, etc.;

Rage comics - featuring a set of expressive characters, each associated with a typical behaviour or emotion. 
The names of sub-genres that potential target groups use for indentifying the material cannot well be translated into other languages. Even a cursory glimpse into the realisation and reflection of meme genres, for example, on some Estonian websites, refers to the unwillingness of the participants to coin local-language terms. Shifman in her book (p. 155) also mentions that English operates as lingua franca on the Internet, yet also points to the gradual diversification in this sphere.

The issue of locality and/or globality in the spread of concrete memes is separately discussed in chapter 9 (p. 151). It appears that memes can be signs of global message forwarding, yet others spread also if translated into local languages. Photoshopped memes based on the events and facts of the physical world do not necessarily evoke a global response and go viral. It is interesting that series of verbal jokes translated into local languages are disseminated, which characterise human predicaments by means of computer technology (Shifman refers to this example). A concrete flash mob watcher has no problem with adaptation: the video makes it possible to see anyone's flash mob performed in any form. Yet, in the case of a flash mob, sharing and initiation are essential: in a most perfect case, this requires bodily action, so-called translation into the language of an individual body. Typical characters of rage comics (Rage Guy, Poker Face and Troll Face, see p. 116) seem to attract specific user groups, whereas the users' non-digital locality is totally irrelevant. It is namely in the case of this meme genre that Shifman warns, with a reference to Ryan Milner's study, that digital literacy is not enough in order to participate in the "rage discourse", or, to put it in a simpler way, a computer user with office background should not even try. The rage comics community watches, shares and creates memes by specific subcultural codes and norms, which evolve within the community.

Besides, as Shifman admits, meme creation and forwarding logic feature influential socio-psychological and subcultural factors. On the one hand, hypermemetic logic dominates (p. 4, 22), releasing vernacular creativity (p. 97, 99), and this in turn sprouts a stream of memes at almost every public event. On the other hand, memes often involve meanings and ways of information processing from smaller user communities, which cannot be understood by the wider public, not to mention those who are not active Internet users.

The question of which earlier cultural practice or folkloric expression could be described as an example of a seemingly new category contended by types of Internet memes is rather inspiring. Limor Shifman's book provides a smartly structured overview of a vernacular creative process independent of the ways of official information channelling expressed in digital culture. Multilayered material flows abounding in information and all kinds of allusions have been skilfully placed in an analytical focus. Memes in Digital Culture provides material for contemplations both to the observers of Internet phenomena and the researchers of folklore born directly in digital culture. I believe that folklorists who are well acquainted with classical expressive genres can, by means of our special language and knowledge, contribute substantially to the interpretation of the novel cultural phenomena.

Mare Kalda 


\section{CONTEMPLATING FAIRY TALES}

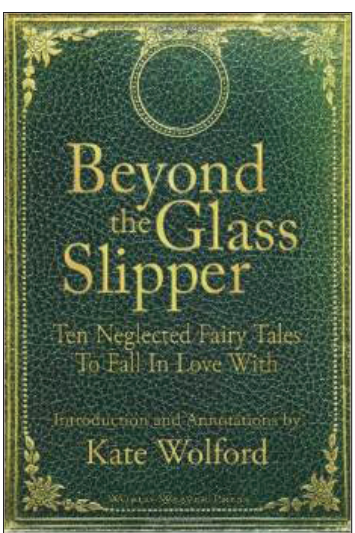

Kate Wolford (Introduction and Annotations). Beyond the Glass Slipper. Ten Neglected Fairy Tales To Fall In Love With. Kalamazoo, Michigan: World Weaver Press, 2013. 158 pp.

Kate Wolford's book serves as a good introduction for those who are discovering the world of fairy tales and would like to know more about it as well as think along the same lines as the author. The author wishes to lead the reader to the world of fairy tales in an easy and delightful way, providing matter-of-fact tips to orientate and find the right way. Yet, she is not willing to impose her own opinion on the reader, but is rather eager to show that fairy tales can be interpreted in different ways, all of which are equally important.

In the introduction to the book, the author formulates one of her objectives: to uncover and rediscover fairy tales that have been overshadowed by their popular counterparts (Snow White, Sleeping Beauty, Rapunzel, etc.). To this end, she has found ten stories, which originate from the most famous fairy tale collections of the 19th century (mainly authored by Andrew Lang, H. Cr. Andersen and the Brothers Grimm), yet have fallen into oblivion later on.

To inspire the reader and make them contemplate, the author gives a short introduction at the beginning of each fairy tale, in which she draws attention to the aspects that should be considered at each of the stories. The author is interested in what is behind these stories, and why the characters behave like they do, why certain elements and motifs have been used, etc. By means of different questions and observations the author provides a key for unlocking these old stories, enabling us to peep inside.

This is not a scientific publication but rather one of a popular style, introducing the fairy tale genre to the wider public and indicating that fairy tales are not only part of children's literature but also offer joy of discovery to adults.

Kärri Toomeos-Orglaan 


\section{OUR AUTHORS}

Anu Korb is a senior researcher at the Estonian Folklore Archives of the Estonian Literary Museum. Her main fields of research include folkloristic fieldwork theory, migration, oral history and folklore of Estonian communities in Siberia.

korb@folklore.ee

Aivar Jürgenson is a senior researcher at the Institute of History of the University of Tallinn. His main fields of research are migration, diaspora culture of Estonians, oral history, ethnobotany, and history and culture of Siberia.

aivarj@tlu.ee

Sanita Reinsone, $\mathrm{PhD}$, is a researcher at the Archives of Latvian Folklore (Institute of Literature, Folklore and Art, University of Latvia). Her research interests primarily concern oral narratives of human's relationship with nature, as well as migration and digital archives.

sanita.reinsone@lulfmi.lv

Astrid Tuisk is a researcher at the Estonian Folklore Archives of the Estonian Literary Museum. She is $\mathrm{PhD}$ student at the University of Tartu. Her main research areas are contemporary children's folklore (jokes and games) and folklore and history of Siberian Estonians.

astrid@folklore.ee

Sandis Laime is a researcher at the Institute of Literature, Folklore and Art of the University of Latvia. His main research interests are Latvian folk belief, place-related narratives and Latvian diaspora in Siberia.

sandis.laime@lulfmi.lv

Aigars Lielbārdis, $\mathrm{PhD}$, is a researcher at the Archives of Latvian Folklore of the Institute of Literature, Folklore and Art, University of Latvia. His scientific interests are in the fields of Latvian charming tradition, calendar customs, Latvian diaspora, and visual culture.

aigars.lielbardis@lulfmi.lv

Andreas Kalkun works as researcher at the Estonian Folklore Archives and has a PhD in folkloristics from the University of Tartu. He has explored the history of Estonian folklore studies, focusing on the problems of representations of the Setos and their folklore, mainly folk songs and vernacular religion. Kalkun has conducted extensive fieldwork in the historical Seto habitat in Estonia and Russia. He is participating in the research project "Embodied Religion. Changing Meanings of Body and Gender in Contemporary Forms of Religious Identity in Finland", led by Elina Vuola, professor of Finnish Academy.

andreas@folklore.ee 
Janika Oras is a senior researcher at the Estonian Folklore Archives at the Estonian Literary Museum, and a teacher of traditional singing at the Estonian Academy of Music and Theatre, where she received her doctoral degree in ethnomusicology. She has studied Estonian singing traditions, history of folklore collecting, and edited publications of and about traditional songs.

janika@folklore.ee

Piret Õunapuu is a historian and ethnologist working at the Estonian National Museum. Her main fields of interest include the history of the Estonian National Museum, traditional farm architecture, farm furnishings and peasant traditions. She has been curator of several exhibitions introducing different facets of Estonian culture both in Estonia and abroad. She is Chair of the Estonian Museum Association and board member of the Learned Estonian Society.

piret.ounapuu@erm.ee 